\title{
WATER RESOURCES OF THE YAP ISLANDS
}

By Otto van der Brug

U.S. GEOLOGICAL SURVEY

Water-Resources Investigations Report 82-357

Prepared in cooperation with the

TRUST TERRITORY OF THE PACIFIC ISLANDS and the

STATE OF YAP, FEDERATED STATES OF MICRONESIA

Honolulu, Hawai i 


\section{UNITED STATES DEPARTMENT OF THE INTERIOR \\ JAMES G. WATT, Secretary}

GEOLOGICAL SURVEY

Dallas L. Peck, Director

For additional information

write to:

District Chief

U.S. Geological Survey, WRD

Room 6110, 300 Ala Moana Blvd.

Honolulu, Hawai i 96850
Copies of this report

may be purchased from:

Open-File Services Section

Western Distribution Branch

U.S. Geological Survey

Box 25425, Federal Center

Denver, Colorado 80225

(Telephone: [303] 234-5888) 
Abstract --

Page

Introduction -

Cooperation - 2

Purpose and scope -

Geographic setting - 3

History -

Population - 5

Previous investigations - 5

Acknowledgments

Climate - 7

General - 7

Rainfall -

Evaporation - 9

Air temperatures - 10

Geology -

Descriptive geology - 13

Water-bearing characteristics 16

Water resources - 17

General - 17

Surface water - 20

General - 20

Streamf low characteristics

Rainfall-runoff relations - 24

Flow-duration curves 27

Low-flow frequency tables 29

High-flow frequency curves 29

Correlation of partial record with continuous record - 38

Historical and existing developments 38

Ground water - 49

Historical developments - 49

Nature and occurrence 


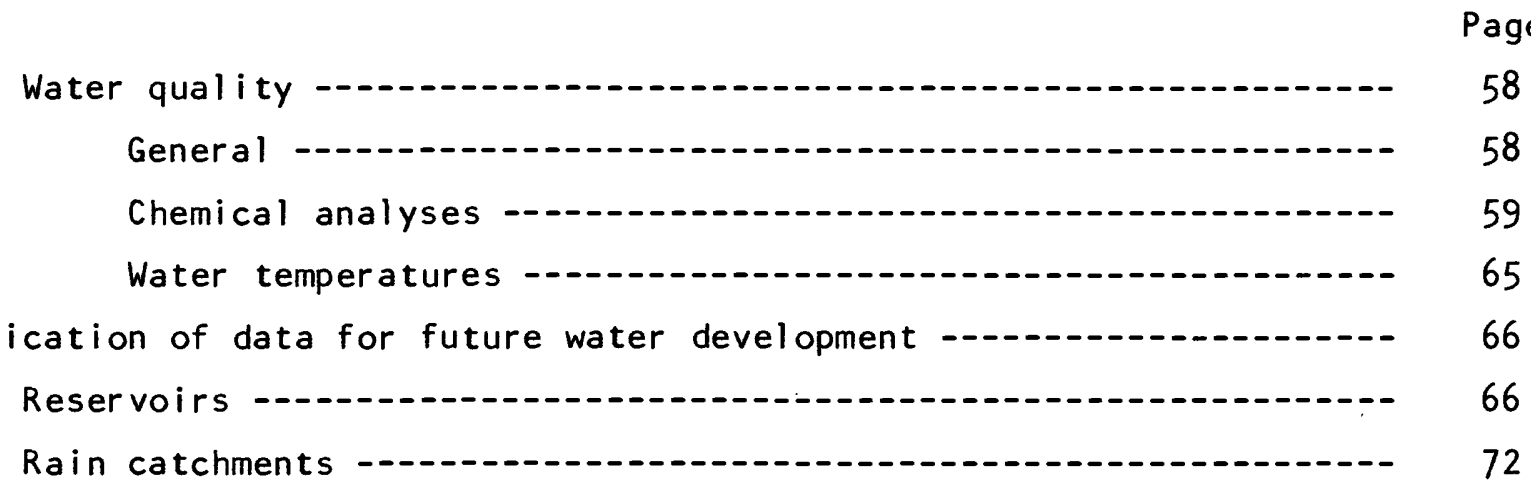

Summary

Hydroliogic data

Rainfall -

Evaporation

Air temperatures

Streamfl ow records

Gaging stations - 96

Low-flow partial-record stations - 132

Miscellaneous measurements 143

Water quality

Chemical analyses 144

Water temperatures 157

References 


\section{ILLUSTRATIONS}

Figure

Page

1. Map showing the location of the Yap Islands

2. Map showing the location of rain gages

3. Graph showing Yap rainfall, temperature, and

Guam evaporation, 1956-80 12

4. Map showing geology of the Yap |slands

5. Map showing the location of surface-water data-collection sites 18

6. Photograph of gaging station on Mukong Stream, Gagil-Tamil ---- 19

7. Photograph of gaging station on Qaringeel Stream, Yap -...- 19

8. Graph showing flow-duration curves of four streams on

Yap Island and one on Gagil-Tamil 28

9.-13. Graphs showing magnitudes and frequencies of

highest mean discharges for duration indicated for

the following streams:

9. Qaringeel Stream, Yap - 32

10. Daloelaeb Stream, Yap - 33

11. Peemgoy Stream, Yap - 34

12. Taalgum Stream, Yap - 35

13. Burong Stream, Yap 36

14. Graph showing magnitude and frequency of annual and

instantaneous peak flows for four continuous-record

stations on Yap Island, 1969-79 37

15.-19. Graphs showing correlations between discharges at

following locations:

15. Tamaney and Qaringeel Streams - 40

16. Ripu and Qaringeel Streams 41

17. Tholomar and Qaringeel Streams - 42

18. Maabuuq and Peemgoy Streams -.- 43

19. Gilaew Stream and Gilaew Spring 44

20. Photograph of Airport swamp with wreck of

Japanese fighter plane 46

21. Photograph of 25-Mgal (upper) reservoir at Gitaem, Yap --_-_ 47

22. Photograph of 2-Mgal (lower) reservoir at Gitaem, Yap --_-_-- 47

23. Photograph of treatment plant at Gitaem, Yap 


\section{ILLUSTRATIONS}

Figure

Page

24. Map showing the Colonia central water system

25. Map showing the location of wells and spring

on Gagil-Tamil and southern Yap, 1971

26. Map showing the location of wells drilled in 1979 and $1982 \ldots$

27. Map showing the location of sites where chemical

analyses of water were made 60

28. Map of south central Yap Island showing possible dam sites $\ldots .--67$

29.-31. Graphs showing mass curves of mean monthly discharge

values of the following locations:

29. Daloelaeb Stream, Yap 69

30. Peemgoy Stream, Yap - 70

31. Taalgum Stream, Yap 71

32.-35. Graphs showing daily draft rates and storage requirements for

rainfall catchments in Yap Islands for the dry period:

32. In a year with average rainfall (1960) 74

33. In a year with average rainfall (1965) 75

34. In a very dry year (1966) 76

35. In a very dry year (1973) 77 


\section{TABLES}

Table

1. Long-term means, minimums and maximums of rainfall

at or near Colonia during period 1901-82 8

2. Rainfall records of the Yap Islands

3. Surface-water stations in the Yap Islands

4. Mean monthly discharge, monthly percentage of annual means, and percent of no-flow days - 23

5. Annual rainfall-runoff comparison, 1969-81 25

6. Rainfall-runoff comparison for June to December 1969-81_-_-_-- 26

7. Lowest mean value for a number of consecutive days for years ending September 30

8. Correlation between discharges at low-flow partialrecord and continuous-record stations

9. Results of chemical and microbiological analyses on six grab samples from the Colonia water-distribution system -- 50

10. Partial chemical analyses of water samples taken January 1971 - 53

11. Depth to water of wells on Yap and Gagil-Tamil 57

12. Chemical analyses of water from the Spanish well (1952)------ 61

13. Chemical analyses reported by Austin, Smith and Associates (1967) 62

14. Chemical analyses made for Lyon Associates (1979) - 63

15.-16. Draft rates for available storage for several catchment sizes:

15. During the dry period of years with average rainfall 78

16. During very dry years 78

17.-19. Monthly and annual rainfall:

17. During the German Administration - 84

18. During the Japanese Administration - 85

19. For the period 1948-83 86 


\section{TABLES}

Table

Page

20. Mean monthly rainfall for a period of 27-28 years prior to 193887

21. Monthly and annual rainfall at Gagil-Tamil, 1969-73, 1976 -... 87

22. -23 . Cumulative rainfall readings:

22. At Protestant Mission, Colonia, Yap 88

23. Near Taalgum Stream, Yap - 89

24. Daily rainfall at continuous-record rain gage

at LORAN station, Gagil-Tamil 91

25. Monthly and annual evaporation data for Guam and Yap - 93

26. Monthly and annual mean air temperatures for Yap (1921-50) -..- 94

27. Monthly and annual mean air temperatures for Yap (1951-81) -..- 95

28. Streamflow records of Qatliw Stream, Yap:

A. Discharge measurements 96

B. Monthly discharge - 97

29. Streamflow records of Qaringeel Stream, Yap:

A. Annual maximum discharge and peak

discharges above base

B. Annual minimum discharge 100

C. Monthly and annual discharges - 101

30. Streamflow records of Daloelaeb Stream, Yap:

A. Annual maximum discharge and peak

discharges above base

B. Annual minimum discharge (105

C. Monthly and annual discharges _... 106

31. Streamflow records of Peemgoy Stream, Yap:

A. Annual maximum discharge and peak

discharges above base

B. Annual minimum discharge - 110

C. Monthly and annual discharges 


\section{TABLES}

Table

32. Streamflow records of Taalgum Stream, Yap:

A. Discharge measurements made outside the period

of continuous discharge record - 113

B. Annual maximum discharge and peak

discharges above base -- 114

C. Annual minimum discharge - 115

D. Monthly and annual discharges -_- 116

33. Streamflow records of Burong Stream, Yap:

A. Annual maximum discharge and peak

discharges above base -- 119

B. Annual minimum discharge - 120

C. Monthly and annual discharges - 121

34. Streamflow records of Mukong Stream, Gagil-Tamil:

A. Discharge measurements made outside the period

of continuous discharge record -- 124

B. Annual maximum discharge and peak

discharges above base -- 125

C. Annual minimum discharge - 125

D. Monthly and annual discharges -_- 126

35. Streamflow records of Gilaew Spring, Gagil-Tamil:

A. Discharge measurements made after the end

of continuous discharge record -

B. Monthly and annual discharges - 129

36. Streamflow records of Eyeb Stream, Gagil-Tamil:

A. Discharge measurements made outside the period

of continuous discharge record - 130

B. Monthly discharge 131 


\section{TABLES}

Table

Page

37.-47. Discharge measurements of the following

swamp outlets and streams:

37. Faraq Swamp outlets, Yap - 132

38. Galngun Swamp outlet, Yap -- 133

39. Tamaney Stream, Yap - 134

40. Ripu Stream, Yap - 135

41. Dinaey Stream, Yap -- 136

42. Tholomar Stream, Yap - 137

43. Mabuuq Stream, Yap - 138

44. Monguch Stream, Gagil-Tamil - 139

45. Gilaew Stream, Gagil-Tamil - 140

46. Yanbilang Stream, Gagil-Tamil - 141

47. Qamin Stream, Maap - 142

48. Discharge measurements made at miscellaneous sites - 143

49.-61. Chemical analyses of water from:

49. Qatliw Stream, Yap - 144

50. Qaringeel Stream, Yap -_- 145

51. Daloelaeb Stream, Yap -.- 146

52. Peemgoy Stream, Yap -_- 147

53. Taalgum Stream, Yap -..- 148

54. Burong Stream, Yap - 149

55. Mukong Stream, Gagil-Tamil - 150

56. Eyeb Stream, Gagil-Tamil - 151

57. Low-flow partial-record stations on Yap - 152

58. Low-flow partial-record stations and miscellaneous

site on Gagil-Tamil and Maap 153

59. Airport Swamp and Water Treatment Plant, Yap --_---- 154

60. Wells on Yap and Gagil-Tamil 155

61. Airport and Tamil aquifers 156 


\section{TABLES}

Table

62.-81. Water and air temperatures and instantaneous discharge at:

62. Qatliw Stream, Yap 157

63. Qar ingeel Stream, Yap - 157

64. Faraq Swamp outlets, Yap - 160

65. Galngun Swamp outlet, Yap 160

66. Tamaney Stream, Yap - 161

67. Ripu Stream, Yap - 162

68. Dinaey Stream, Yap - 163

69. Tholomar Stream, Yap 164

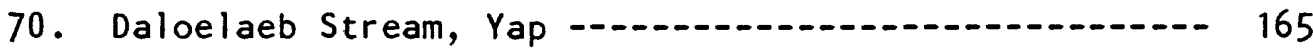

71. Peemgoy Stream, Yap - 167

72. Taalgum Stream, Yap - 170

73. Mabuuq Stream, Yap - 172

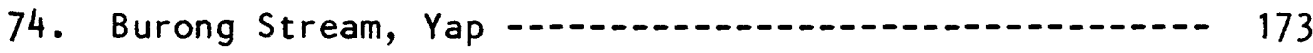

75. Monguch Stream, Gagil-Tamil - 176

76. Mukong Stream, Gagil-Tamil - 176

77. Gilaew Spring, Gagil-Tamil - 180

78. Gilaew Stream, Gagil-Tamil 182

79. Yanbilang Stream, Gagil-Tamil _... 183

80. Eyeb Stream, Gagil-Tamil - 184

81. Qamin Stream, Maap 184 


\section{CONVERSION TABLE}

The following table may be used to convert measurements in the inch-pound system to the International System of Units (SI).
Multiply
By
To obtain

\section{Length}

inch ( in)

25.4

-..- millimeter ( $\mathrm{mm})$

foot $(f t)$

0.3048 -.. meter $(\mathrm{m})$

mile (mi)

1.609 -... kilometer (km)

Area

acre -

square foot $\left(\mathrm{ft}^{2}\right)$

0.0929 -.. square meter $\left(\mathrm{m}^{2}\right)$

square mile $\left(\mathrm{mi}^{2}\right)$

2.590

-..- square kilometer $\left(\mathrm{km}^{2}\right)$

Volume

acre-foot (acre-ft) -........ 1,233

cubic foot $\left(\mathrm{ft}^{3}\right)$

cubic meter $\left(\mathrm{m}^{3}\right)$

$0.02832 \ldots$ cubic meter $\left(\mathrm{m}^{3}\right)$

gallon (gal)

3.785 -.. liter (L)

million gallons (Mgal)

-.- cubic meter $\left(\mathrm{m}^{3}\right)$

Volume Per Unit Time (includes Flow)

cubic foot per second $\left(\mathrm{ft}^{3} / \mathrm{s}\right)$--

$0.02832 \ldots$ cubic meter per second $\left(\mathrm{m}^{3} / \mathrm{s}\right)$

cubic foot per second-day

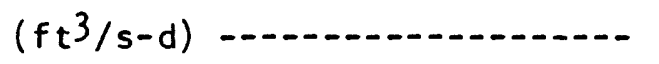

gallon per minute (gal/min) ...-

gallon per day (gal/d)

million gallons per day (Mgal/d)

cubic foot per second per

square mile $\left[\left(\mathrm{ft}^{3} / \mathrm{s}\right) / \mathrm{mi}^{2}\right] \ldots$

micromho per centimeter at

$25^{\circ}$ Celsius ( $\mu \mathrm{mho} / \mathrm{cm}$ at $25^{\circ} \mathrm{C}$ )
2,447 -.- cubic meter $\left(\mathrm{m}^{3}\right)$

$0.06309 \ldots$ cubic decimeter per second $\left(\mathrm{dm}^{3} / \mathrm{s}\right)$

90.85 -..- cubic decimeter per second $\left(\mathrm{dm}^{3} / \mathrm{s}\right)$

$0.04381 \ldots$ cubic meter per second $\left(\mathrm{m}^{3} / \mathrm{s}\right)$

\section{Miscellaneous}

0.01093

cubic meter per second per square $\mathrm{kil}$ ometer $\left[\left(\mathrm{m}^{3} / \mathrm{s}\right) / \mathrm{km}^{2}\right]$ microsiemens per centimeter at $25^{\circ} \mathrm{Celsius}\left(\mu \mathrm{S} / \mathrm{cm}\right.$ at $25^{\circ} \mathrm{C}$ ) 
DEFINITION OF TERMS

\section{Water Resources}

Acre-foot (acre-ft) is the quantity of water required to cover ont acre to a depth of one foot and is equivalent to 43,560 cubic feet or 325,851 gallons.

Control designates a feature downstream from the gage that determines the stagedischarge relation at the gage. This feature may be a natural constriction of the channel, an artificial structure, or a uniform cross section over a long reach of the channel.

Cubic foot per second $\left(\mathrm{ft}^{3} / \mathrm{s}\right)$ is the rate of discharge representing a volume of one cubic foot passing a given point during one second and is equivalent to 7.48 gallons per second or 448.8 gallons per minute.

Cubic foot per second day $\left(\mathrm{ft}^{3} / \mathrm{s}-\mathrm{d}\right)$ is the volume of water represented by a flow of one cubic foot per second for 24 hours. It is equivalent to 86,400 cubic feet, 1.93875 acre-feet, or 646,317 gallons.

Discharge is the volume of water that passes a given point within a given period of time.

Mean discharge (mean) is the arithmetic average of individual daily mean discharges during a specified period.

Instantaneous discharge is the discharge at a particular instant of time. If this discharge is reported instead of the daily mean, the heading of the discharge column in the table is "Discharge."

Dissolved is that material in a representative water sample which passes through a 0.45-um membrane filter.

Drainage area of a stream at a specific location is that area, measured in a horizontal plane, enclosed by a topographic divide from which oirect surface runoff from precipitation normally drains by gravicy into the river above the specified point.

Gage height is the water-surface elevation referred to some arbitrar: gage datum. Gaging station is a particular site on a stream where systematic observations of hydrologic data are obtained. 
Hardness of water is a physical-chemical characteristic that is commonly recognized by the increased quantity of soap required to produce lather, due mostly to the presence of alkaline earths (principally calcium and magnesium) and is expressed as equivalent calcium carbonate $\left(\mathrm{CaCO}_{3}\right)$.

Micrograms per liter $(\mu \mathrm{g} / \mathrm{L})$ is a unit expressing the concentration of chemical constituents in solution as mass (micrograms) of solute per unit volume (liter) of water. One thousand micrograms per liter is equivalent to one milligram per liter.

Milligrams per liter $(\mathrm{mg} / \mathrm{L})$ is a unit expressing the concentration of chemical constituents in solution as mass (milligrams) of solute per unit volume (liter) of water.

Partial-record station is a particular site where limited streamflow and/or water-quality data are collected systematically over a period of years for use in hydrologic analyses.

Runoff in inches shows the depth to which the drainage area would be covered if all the runoff for a given time period were uniformly distributed on it. Sediment is solid material that originates mostly from disintegrated rocks and is transported by, suspended in, or deposited from water; it includes chemical and biochemical precipitates and decomposed organic material, such as humus. The quantity, characteristics, and cause of the occurrence of sediment in streams are influenced by environmental factors. Some major factors are degree of slope, length of slope, soil characteristics, land usage, and quantity and intensity of precipitation.

Specific conductance is a measure of the ability of a water to conduct an electrical current. It is expressed in micromhos per centimeter at $25^{\circ} \mathrm{C}$. Specific conductance is related to the type and concentration of ions in solution and can be used for approximating the dissolved-solids content of the water. Commonly, the concentration of dissolved solids (in milligrams per liter) is about 65 percent of the specific conductance (in micromhos). This relation is not constant from stream to stream, and it may vary in the same source with changes in the composition of the water.

Stage is the water-surface altitude referred to some arbitrary gage datum (gage height).

Stage-discharge relation is the relation between gage height (stage) and volume of water per unit of time, flowing in a channel. 
Streamflow is the discharge that occurs in a natural channel. Although the term "discharge" can be applied to the flow of a canal, the word "streamflow" uniquely describes the discharge in a surface stream course. The term "streamflow" is more general than "runoff" as streamflow may be applied to discharge whether or not it is affected by diversion or regulation.

Turbidity of a sample is the reduction of transparency due to the presence of particulate matter. In this report it is expressed in Nephelometric Turbidity Units (NTU).

\section{Geology}

Alluvium: Soil, sand, gravel, or similar material deposited by running water. Amphibolite: A granulose metamorphic rock consisting essentially of amphibole and plagioclase, and commonly containing quartz, epidote, or garnet.

Basement rock: The assemblage of metamorphic and igneous rocks that underlie the sedimentary and unmetamorphosed volcanic rocks in any particular region.

Breccia: A rock consisting of consolidated angular rock fragments larger than sand grains.

Dike: A tabular body of igneous rock that cuts across the structure of adjacent rocks or cuts massive rocks.

Facies: Designates the aspect or appearance of a mass of earth material different in one or several respects from surrounding material.

Fault: A break or fracture in material of the earth's crust, along which there has been movement.

Muck: Organic material which is decomposed enough so that identification of plant parts is impossible.

Metamorphic rocks: Rock formed by recrystallization of an igneous or sedimentary rock under the influence of heat, pressure, or both.

Schist: A metamorphic rock that splits into thin, irregular plates because of the presence of parallel grains of mica or other cleavable minerals.

Sill: A tabular body of igneous rock that has been injected, while molten, between layers of sedimentary or igneous rock.

Tectonic: Pertaining to the rock structures and landforms resulting from deformation of the earth's crust.

Tuff: Indurated pyroclastic rocks of grain generally finer than $4 \mathrm{~mm}$ (equivalent to volcanic ash or dust). 


\section{WATER RESOURCES OF THE YAP ISLANDS}

\section{By Otto van der Brug}

\section{ABSTRACT}

The Yap Islands consist of four major islands, Yap, Gagil-Tamil, Maap, and Rumung. Of these, Yap Island has more than half the total land area, most of the population, and almost all of the economic development. The islands of Maap and Rumung together compose only 15 percent of the land area and population.

Average annual rainfall over the Yap Islands amounts to 122 inches. Rainfall-runoff comparisons indicate that about half of the annual rainfall runs off to the ocean on Yap Island and Gagil-Tamil. Streams on Gagil-Tamil are perennial but streams on Yap Island are dry an average of 3 month per year due to geologic differences.

Analyses of water samples from 23 sources show the good quality and the chemical similarity of surface and ground water.

This report summarizes the hydrologic data collected and provides interpretations that can be used by the planning and public works officials of Yap to make decisions concerning development and management of their water resources. 


\section{INTRODUCTION}

\section{Cooperation}

In 1968, the U.S. Geological Survey and the Trust Territory of the Pacific Islands signed a joint funding agreement to systematically collect streamflow data.

This program was expanded in 1972, with the addition of several rain gages, and again in 1974, when a senior geologist, Dan Davis, was assigned nearly fulltime to Trust Territory Headquarters to provide advice on exploratory drilling and ground-water development. The collection and analyses of water-quality data were introduced into the program in 1979 with the collection of samples from most streams on the Yap Islands.

Under the cooperative program, the Trust Territory Government agreed to provide labor, equipment, services, and funds to be matched on an equal-value basis by the Geological Survey. The Survey assumed the responsibility of supervision, data compilation and analyses, and publication.

In 1981, after the formation of the Federated States of Micronesia, the responsibility for the matching funds and services was transferred from the Trust Territory Government to the separate states.

\section{Purpose and Scope}

The bulk of the hydrologic data collected by the Geological Survey since 1967 on the major islands in the Trust Territory of the Pacific Islands consists of records of discharge and stage of most of the principal streams. More recently, the data base has been expanded to include information on ground-water resources, water quality, and rainfall. Most of the data have been published by the Geological Survey in its annual release "Water Resources Data for Hawai and Other Pacific Areas," and for 1968-70 in Water-Supply Paper 2137. Miscellaneous measurements made prior to 1968 were published in the 1968 annual report.

This report has two purposes: first, to provide a summary of available water-resources information for the Yap Islands; and second, to provide interpretations that can be used by planning and public works officials of Yap to make decisions on the future development and management of their water resources. 


\section{Geographic Setting}

The Yap Islands are part of the Western Caroline Islands and Iie between $9^{\circ} 27^{\prime}$ and $9^{\circ} 38^{\prime} \mathrm{N}$. latitude and $138^{\circ} 03^{\prime}$ and $138^{\circ} 12^{\prime} \mathrm{E}$. longitude, 450 miles southwest of Guam, 1,100 miles east of Manila, 1,900 miles south of Tokyo, and 3,800 miles west of Honolulu ( $\mathrm{fig} .1$ ).

The islands of Yap, Gagil-Tamil, Maap, and Rumung are the four major islands and have a total land area of $38 \mathrm{mi}^{2}$ (square miles). The smaller islands of Maap $\left(4.1 \mathrm{mi}^{2}\right)$ and Rumung $\left(1.6 \mathrm{mi}^{2}\right)$ are separated from Yap and Gagil-Tamil by narrow, shallow channels. Mangrove swamps border much of the shoreline, whereas the interior is mountainous with forested valleys and rolling grass-covered hills. A mountain range runs in a north-south direction along the eastern coasts and averages about 600 feet in height on Yap Island and about 250 feet on the other three islands. Plains are found at lower elevations in central Gagil-Tamil and southern Yap.

\section{History}

In 1525, the Portuguese Navigator, Diego de Rocha, was blown off course on a trip from the Island of Celebes to Ternate Island. He spent some time on a large island which, from his descriptions, could only have been Yap Island. The next recorded western contact with Yap came 100 years later when a Dutch expedition under Schapendam visited Yap and Ulithi, an atoll 106 miles east of the Yap Islands (Friis, 1967).

Although generally considered to be in the Spanish sphere of interest, Spain showed little interest in the Caroline Islands until Germany tried to claim the islands in 1885. This dispute between Spain and Germany was settled the following year by Pope Leo XIII in favor of Spain.

Spanish rule ended in 1899 when Germany purchased the Caroline Islands. The Germans were succeeded by the Japanese who occupied the Yap Islands in 1914 after the outbreak of World War I. In 1920, Japan received a mandate from the League of Nations to administer the islands. After withdrawing from the League in 1935, Japan annexed the islands as part of its empire. At this time there were 392 Japanese on the Yap Islands (Great Britain Naval Intelligence Div., 1945). The Japanese population grew rapidly with the influx of troops and the military construction. 


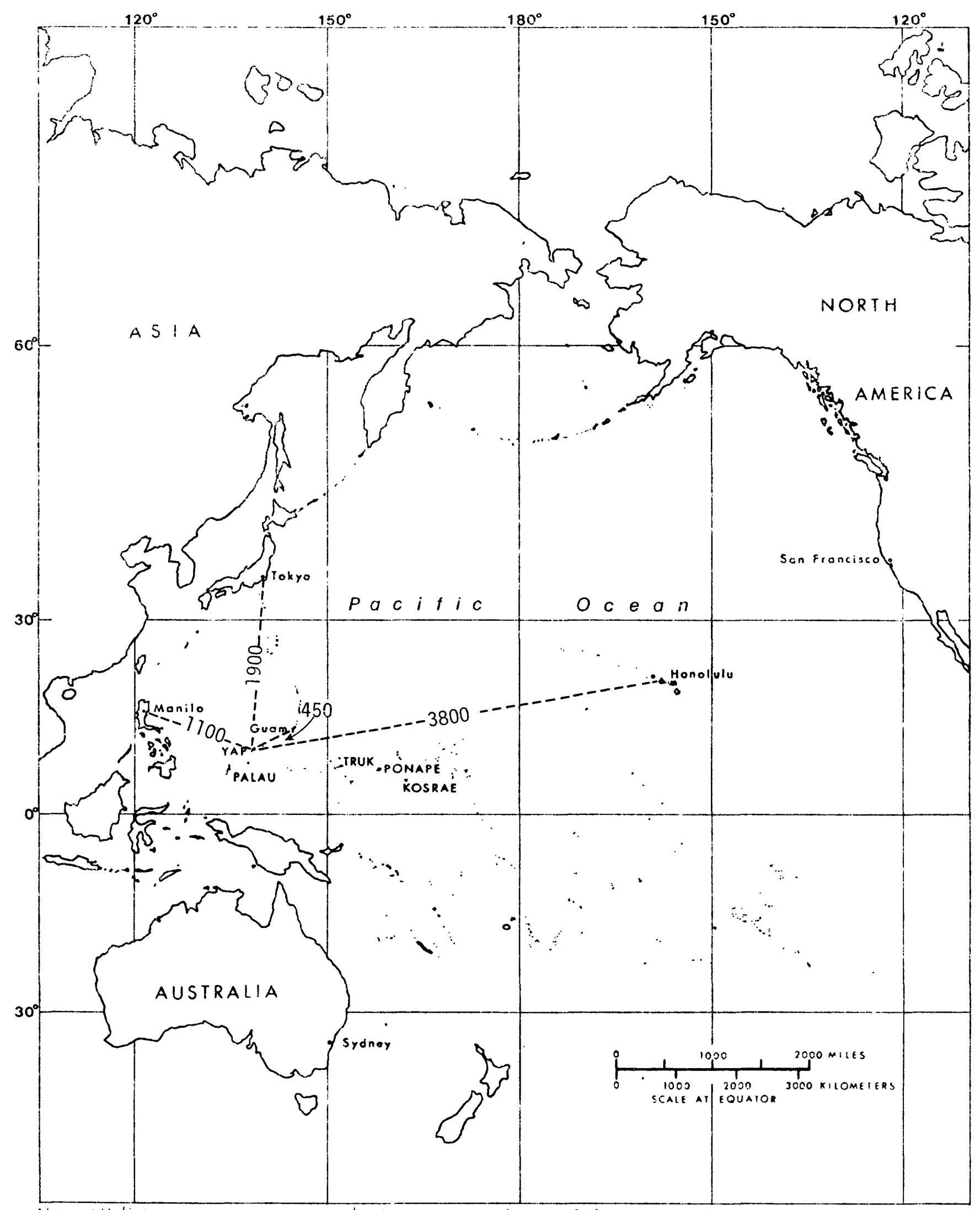

Note: All distances cre in statule miles ione statute mile is 0868 nouical malel

Figure 1. Location of the Yap Islands. 
In 1945 after the end of World War II, Americans occupied the islands which will remain under American Administration until their impending independence as a state of the Federated States of Micronesia.

\section{Population}

Nearly 8,000 people live in the islands, which is double the population of 25 years ago, according to Trust Territory statistics (U.S. Department of State, annual reports). Since World War 11 , the yearly population increase has been 3 to 4 percent; practically all from births exceeding deaths. This increase reversed a long period of population decrease, which began with the first European contact.

In 1783, the population was estimated at 40,000, which appears exaggerated. The estimate in 1862 was 10,000. During the German Administration (1899-1914), 84 inhabited villages were counted along with 150 deserted sites. The population had decreased to 6,328 in 1910 and in 1935, only 3,713 were counted (Great Britain Naval Intelligence Div. 1945).

Because of lower temperatures and traditional dependence on the sea for subsistence, most of the population lives in villages scattered along the coast. The only town on Yap is Colonia, the seat of Government during German, Japanese, and American Administrations, and now, the capital of Yap State.

The economic base of the islands is narrow. Practically all employment is with the Government in Colonia.

\section{Previous Investigations}

The earliest known reports on the Yap Islands were a petrographic study of rocks by Erich Kaiser in 1901 (Kaiser, 1902) and a later one by Koert and Finckh (Johnson and others, 1960).

The first geologic study was made during the Japanese Administration when a map by Risaburo Tayama of the geology of Yap was published (Tayama, 1935). Since World War II, several studies have been made by scientists from the U.S. Geological Survey.' Josiah Bridge participated in an economic survey of mineral resources in 1946 (Bridge, 1946), and Charles G. Johnson worked on detailed geologic mapping of Yap during 1947-48 and again in 1956 (Johnson and others, 1960). Arthur M. Piper wrote a report in $1947 \mathrm{titled,} \mathrm{"Water} \mathrm{Resources} \mathrm{of} \mathrm{Guam}$ and the ex-Japanese Mandated Islands in the Western Pacific." 
A soil survey was made by Richard J. Alvis and Robert L. Hetzler in 1956-57 for the large volume, "Military Geology of Yap Islands," written by Messrs. Johnson, Alvis, and Hetzler, with the exception of the weather and climate sections.

Very little water-resources data had been collected prior to the start of the cooperative U.S. Geological Survey-Trust Territory program in 1968 with the exception of rainfall information, available for most years since 1900, which was compiled for this report from several sources.

\section{Acknowledgments}

From the preliminary reconnaissance made by M. M. Miller in 1965 (written communication, 1965) until the present time, the cooperation of the Headquarters Staff of the Trust Territory of the Pacific Islands on Saipan and of officials in the Yap District has been outstanding.

Special commendations are made to the following officials: Koichi L. Wong, who has been involved in all phases of this work since 1965; Louis F. Irving, who acted as liaison with Trust Territory Headquarters; the Yap District Directors of Public Works, W. F. Dupont and M. Melarei; and those listed below who did most of the data collection:

$\begin{array}{ll}\text { Mark Loochaz } & 1967-1969 \\ \text { Richard Mungwaath } & 1969-1970 \\ \text { George Giltharngan } & 1970-1971 \\ \text { Florent in Yangilmau (Palau) } & 1972 \\ \text { Hers Bosil } & 1973-1975 \\ \text { Adrian Gimed } & 1975-\text { present. }\end{array}$




\section{CLIMATE}

\section{General}

Because the Yap Islands lie near the Equator in an immense ocean, the climate is generally warm and humid. Temperatures vary little, averaging about $27^{\circ} \mathrm{C}$, with the difference between the means of the warmest and coolest month for the period $1921-81$ being only $2.6^{\circ} \mathrm{C}$. From 1949-81, the maximum temperature was $30.5^{\circ} \mathrm{C}$ and the minimum $24.1^{\circ} \mathrm{C}$. Relative humidity averages 83 percent annually, and is generally lowest in the afternoons between February and April and highest in the early morning hours from June through December.

There are two principal seasons separated by short-duration transition periods. December through April is the "dry" season, with predominant trade winds from the east to northeast. July through October is the "wet" season, characterized by heavy showers, occasional thunderstorms, west and southwesterly winds interspersed with frequent periods of light winds and calms.

Typhoons on Yap are rare, as most pass well north of the islands in a westerly direction. The worst typhoon known to strike Yap occurred on December 17 , 1920, causing five deaths and the destruction of 1,330 houses from flooding of coastal areas (Government of the Philippine Islands, Weather Bureau, December 1920). Maximum windspeed was estimated at 100 miles per hour. 0ther destructive typhoons occurred in 1918 and on December 15, 1925, which, combined with a tsunami, destroyed more than 90 percent of all houses.

Rainfall averages 122 inches per year, with monthly rainfall extremes ranging from 0.2 inch for April 1926 to 45.9 inches for July 1911 (table 1).

\section{Rainfall}

Although rainfall records for Yap, other than those at or near Colonia, are of short duration or uncertain quality or both, they do show there is little difference in annual rainfall throughout the Yap Islands.

Although rain showers of ten are localized, the relatively low profile of the islands will cause these showers to occur at random, and thus are averaged in the yearly total. 
Table 1. Long-term means, minimums and maximums of rainfall, in inches, at or near Colonia during period 1901-82 (No record available 1909, 1910, 1944-48)

\begin{tabular}{lcrrrrrrrrr}
\hline \multicolumn{3}{c}{$\begin{array}{c}\text { Number of } \\
\text { years }\end{array}$} & Mean & Percent & $\begin{array}{c}\text { Minimum } \\
\text { monthly }\end{array}$ & Year & $\begin{array}{c}\text { Maximum } \\
\text { monthly }\end{array}$ & Year & $\begin{array}{c}1 / 24 \text {-hour } \\
\text { maximum }\end{array}$ & Year \\
\hline \multirow{2}{*}{ January } & 75 & 7.5 & 6.1 & $\underline{2} / 1.5$ & 1913 & 23.1 & 1955 & 10.45 & 1958 \\
February & 74 & 5.7 & 4.7 & $\underline{3} / 0.7$ & 1915 & 22.6 & 1902 & 5.94 & 1962 \\
March & 73 & 5.8 & 4.8 & 0.8 & 1929 & 17.1 & 1911 & 5.09 & 1963 \\
April & 74 & 5.9 & 4.8 & 0.2 & 1926 & 18.2 & 1956 & 6.57 & 1962 \\
May & 75 & 9.5 & 7.8 & 2.6 & 1926 & 19.3 & 1928 & 10.06 & 1967 \\
June & 75 & 11.0 & 9.0 & 3.4 & 1913 & 32.0 & 1982 & 13.17 & 1982 \\
July & 75 & 15.5 & 12.7 & 4.8 & 1904 & 45.9 & 1911 & 9.92 & 1911 \\
August & 75 & 15.4 & 12.6 & 5.1 & 1973 & 32.1 & 1940 & 7.57 & 1970 \\
September & 75 & 13.7 & 11.2 & 5.8 & 1915 & 28.2 & 1904 & 8.35 & 1978 \\
October & 74 & 12.5 & 10.2 & 2.6 & 1976 & 24.0 & 1933 & 5.32 & 1961 \\
November & 74 & 10.1 & 8.2 & 1.2 & 1913 & 22.5 & 1924 & 8.91 & 1960 \\
December & 73 & 9.6 & 7.9 & 2.2 & 1928 & 23.1 & 1938 & 5.61 & 1981 \\
\cline { 2 - 10 } Year & $4 / 122.1$ & 100 & 0.2 & 1926 & 45.9 & 1911 & 13.17 & 1982 \\
\hline
\end{tabular}

1/ For period 1902-08, 1911, 1913-20, 1949-81.

2/ Rainfall for January 1983 was less: 1.25 inches.

3/ Rainfall for February 1983 was less: 0.27 inches.

4/ Sum of 12 monthly means. 
Cumulative rainfall readings at Geological Survey rain gages are of short duration and because of vandalism and other problems, some readings were not made. Some evaporation may have occurred between readings but data given in tables 22 and 23 in the Hydrologic Data section correlate well with National Weather Service records.

The available rainfall record of the U.S. Coast Guard LORAN station on Gagil-Tamil for 1969-73, 1976 (table 21) compared well with the record of the Weather Service station at Yap Airport (table 19) except for the 29-percent difference shown by the 1970 totals. The LORAN station reading of 4.10 inches for August 1970 appears to be inaccurate because streamflow records for Gilaew Spring, Gagil-Tamil, for the month of August 1970 show the highest monthly discharge of the year which is consistent with the Weather Service Yap Airport rainfall total of 25.45 inches for the month. In December 1981, the U.S. Geological Survey established a recording rain gage at about the same location as the previous U.S. Coast Guard station (table 24).

Table 2 lists the locations and periods for which rainfall records have been collected on the Yap Islands and figure 2 shows the location of these rain gages. In the Hydrologic Data section, tables 17-19 list the monthly and annual totals of rainfall records for most of the period 1900-1983.

\section{Evaporation}

Pan evaporation data for Yap are available from July 1978 to December 1982 and are summarized in table 25 in the Hydrologic Data section. Table 25 also lists monthly pan evaporation data for the Island of Guam beginning in January 1956. The monthly values of the common period of record (July 1978 to December 1982) are not well correlated; however, comparison of the evaporation totals for the common period ( 53 months) is close (Guam is 8 percent higher). Until the evaporation record for Yap is longer, the annual evaporation data from Guam could be used to estimate the annual evaporation on Yap. Based on the data compiled in table 25, the average annual evaporation for Guam for the period January 1956 to December 1982 is 76.98 inches. This was determined by averaging the monthly data and adding the means. Monthly records ranged between 24 and 26 years. For the short period of record on Yap, the total of monthly means is 75.15 inches.

Figure 3 illustrates the seasonal relatiouship between rainfall, temperature, and evaporation (from Guam) for the Yap Islands. 


\section{Table 2. Rainfall records of the Yap Islands}

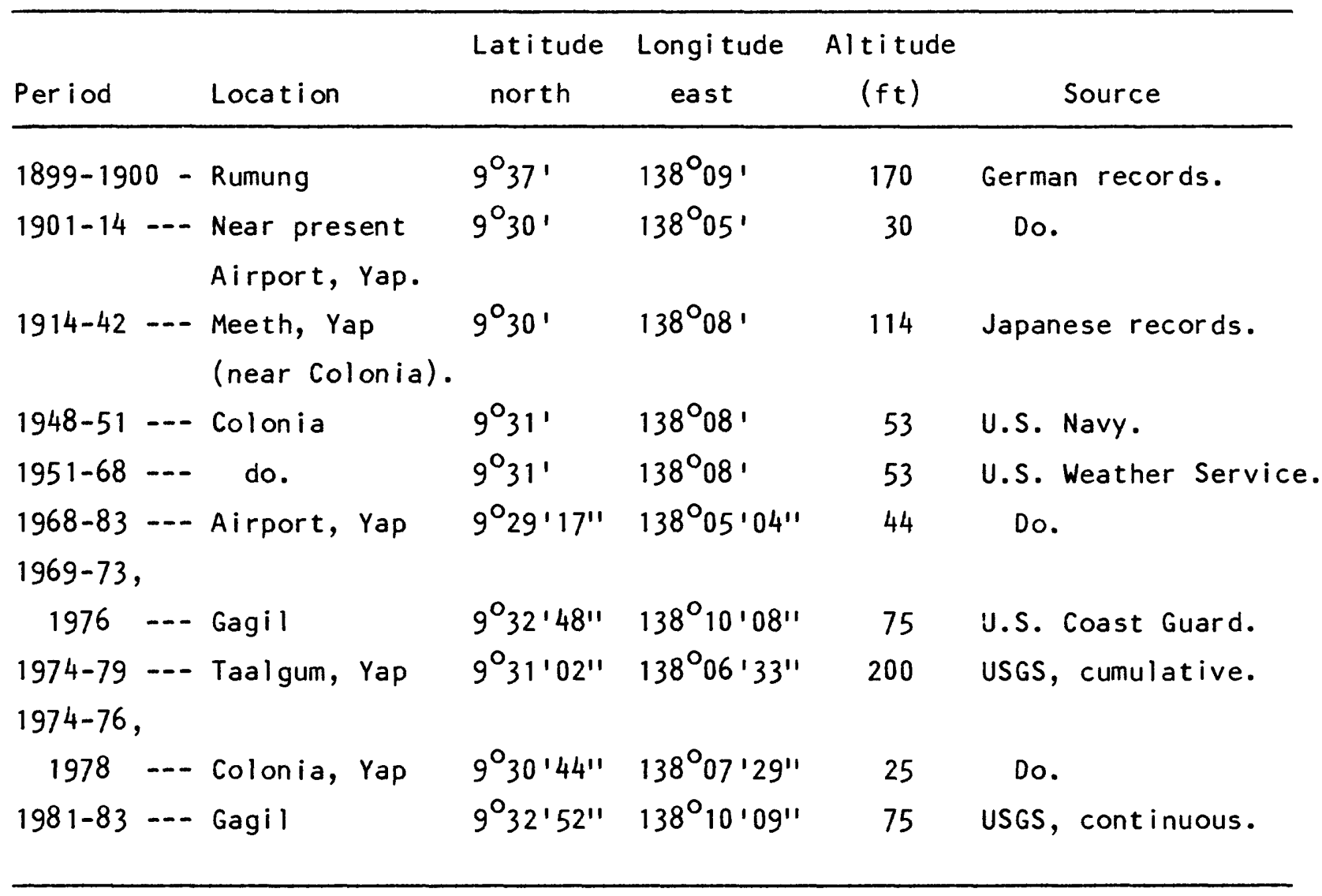

\section{Air Temperatures}

Monthly mean air temperatures for Yap for the period 1921-1981 are listed in tables 26 and 27 in the Hydrologic Data section. From these data the mean annual air temperature is $27.3^{\circ} \mathrm{C}$. Other readings of air temperature were made in conjunction with surface-water temperature readings during streamflow measurements and can be found in tables 62-81 in the Hydrologic Data section. 


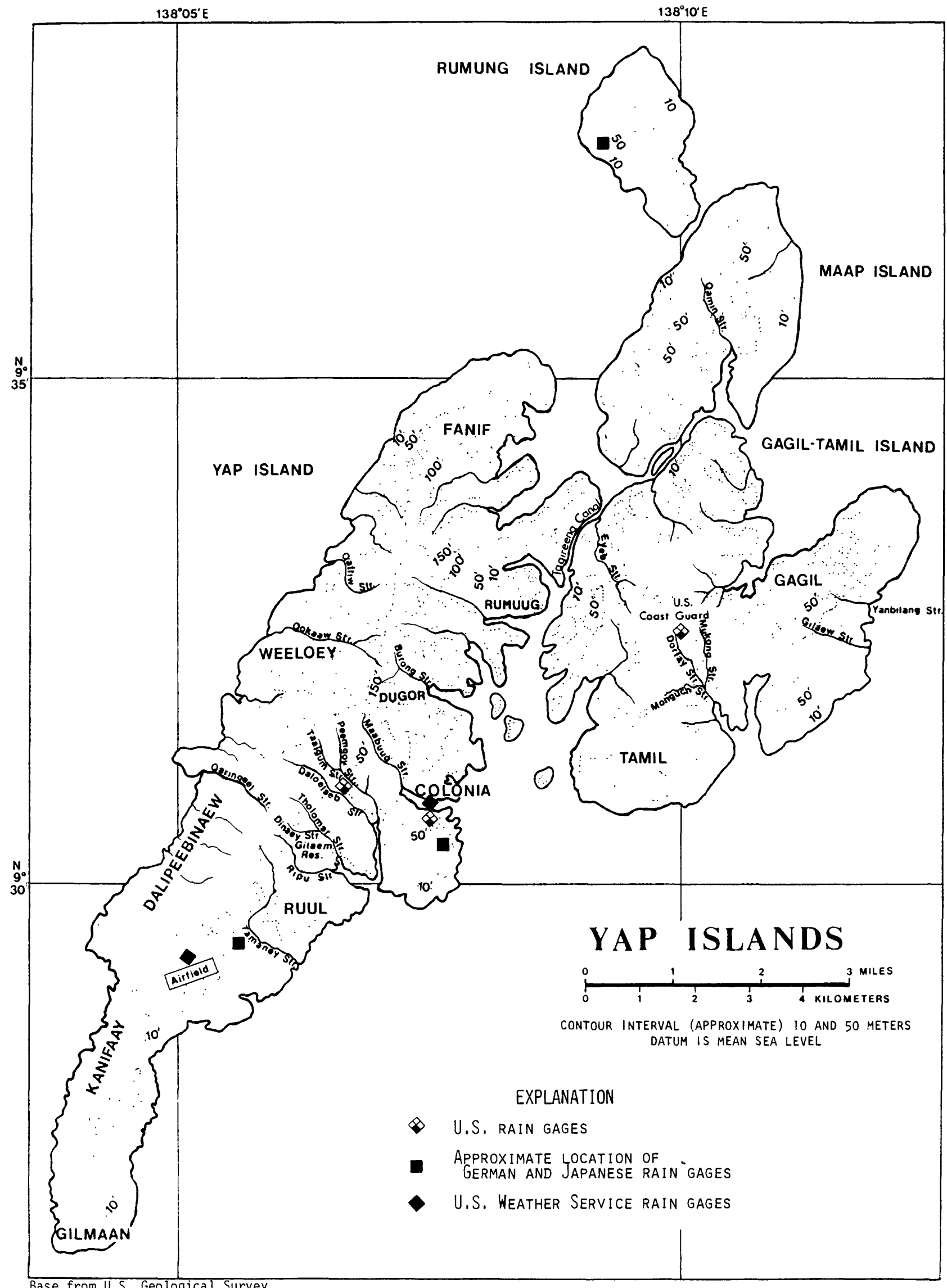

Base from U.S. Geological Survey

Yap Islands 1981 (preliminary).

Figure 2. Location of RAIN Gages 


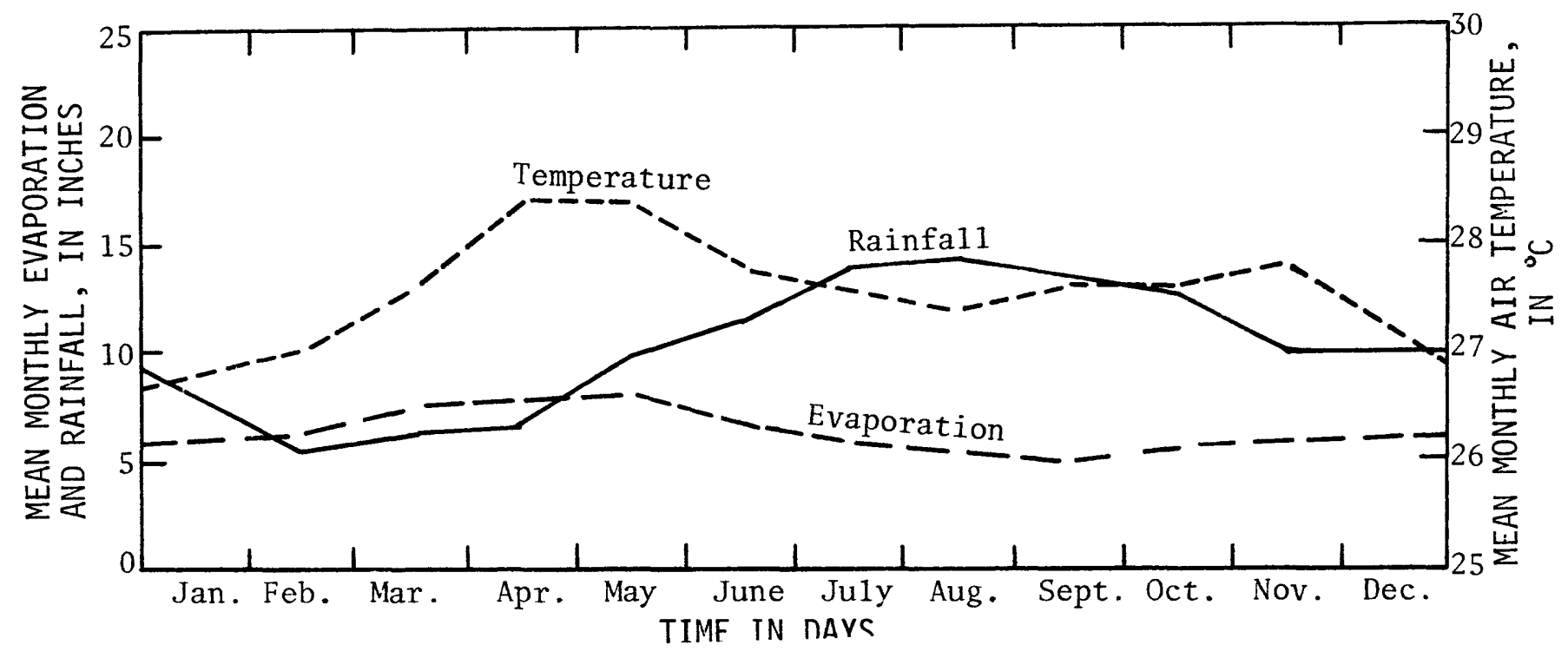

Figure 3. Yap rainfa11, temperature, and Guam evaporation, 1956-80. 


\section{GEOLOGY}

This chapter is a summary from "Military Geology of Yap Islands, Caroline Islands" (Johnson and others, 1960).

\section{Descriptive Geology}

The geologic map of the Yap Islands ( $\mathrm{fig}$. 4) shows the major rock units that are found on the islands.

The basement rocks were named the Yap Formation by Tayama (1935) who defined it as "*** the crystalline schists which develop on Yap proper." This formation underlies the northern three-fourths of Yap Island, the northwestern threefourths of Rumung, and a prominent ridge in western Gagil-Tamil. A small outcrop occupies the hilltop at Leebinaew, on eastern Gagil-Tamil, at the site of a destroyed lighthouse.

The Yap Formation is a complex of metamorphic rocks of the green schist and amphibolite facies, that have a considerable range in texture but only a rather limited range in mineral composition. The formation is pre-Miocene, possibly Mesozoic, in age. The thickness of the formation is unknown. It is the basement rock (the lowermost, oldest rock) on the island and its lower limits, therefore, are not exposed.

The rocks of the Yap Formation weather to fat clay, which is gray to greenish in color near the weathered rock surface, and grades upward to yellowish and, in some places, red clay at the surface of the ground.

Serpentinite dikes and sills, mostly 1 to 10 feet thick and of unknown extent, are scattered throughout the Yap Formation; most are serpentinized peridotite. The rock is dense, dark green to nearly black, with faint grayistigreen spots or mottles. Only the large outcrop areas in Gagil-Tamil are included on the geologic map; outcrops on Yap Island are too small to be shown. The age of the serpentine cannot be determined more closely than pre-Miocene (preTertiary).

The serpentinite weathers to a ferruginous clay. As much is 27 feet of this material was measured with an auger. The clay contains iron and a small percentage of nickel. During World War II, the Japanese South Seas Development Co. prospected the deposits and shipped some ore to Korea and Japan for smelting. 


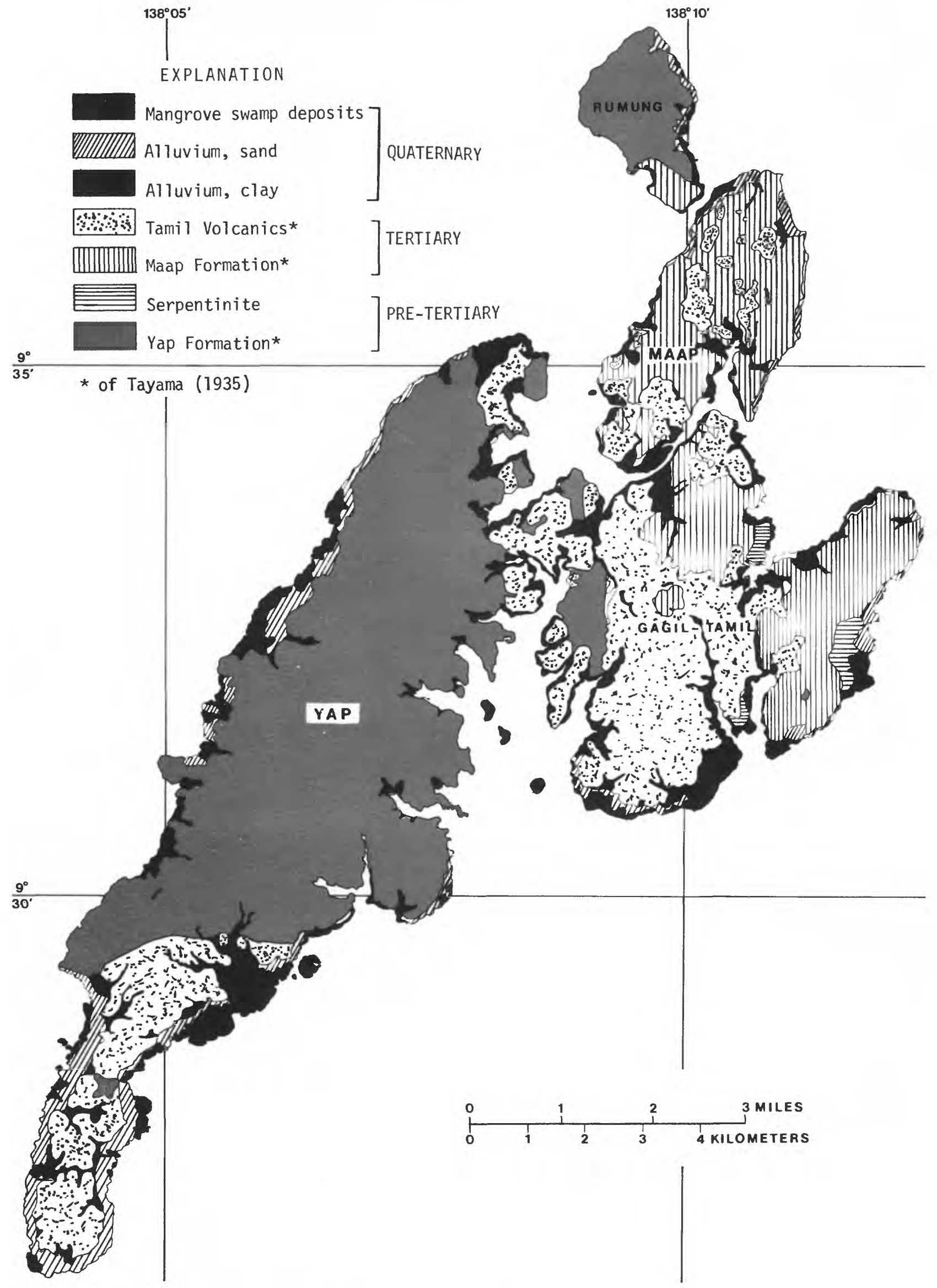

Figure 4. Geology of the Yap Islands (Johnson and others, 1960). 
Overlying the basement rocks in the northeastern part is the 0ligocene Map (Maap) Formation of Tayama (1935), composed entirely of fragmental rock of both tectonic and sedimentary origin, and includes breccia, conglomerate and interbedded sandstone and siltstone. The formation is named from good exposures in the sea cliffs along the east side of Maap. It also crops out on Gagil-Tamil and Rumung.

The breccia of the Map (Maap) Formation is a massive deposit of angular to subangular fragments, mostly of metamorphic rocks but including a great variety of other rock types, embedded in a matrix of finely crushed rock. Fragment sizes range from less than 1 inch to 9 feet. The matrix is light gray in color and is composed of sand-size to clay-size particles of ground rock.

Gravel-to silt-size sediments occupy channels cut into the breccia, and are faulted into it. Particle size of the conglomerate ranges from fine sand to boulders. The conglomerate grades laterally and vertically into deposits of sandstone and siltstone. Most of it is well bedded and up to 8 feet thick.

Faulting of the Map (Maap) Formation has greatly complicated the structure and stratigraphy of the sedimentary rocks. At almost every outcrop of the Map (Maap) Formation there are faults, most nearly vertical, that cut the breccia or sedimentary deposits, or both.

The thickness of the Map (Maap) Formation is variable and any figure given for it is highly speculative. It is thickest on Maap where it may exceed 250 feet. The formation is considered relatively thin in eastern Gagil-Tamil, as there are many outcrops of serpentine and rock of the Yap Formation in the area.

The Tomil (Tamil) Volcanics of Tayama (1935), composed of andesitic tuffs, volcanic breccias, and lava flows, all almost completely weathered to clay, unconformably overlie the breccia and basement rocks in the central part and the southern-most tip of the Yap Islands. The formation was deposited upon strongly eroded older rocks and probably is at least several hundred feet thick in central Gagil-Tamil, where it is typically exposed. The Tomil (Tamil) Volcanics probably are 01 igocene and Miocene in age (12-28 million years ago). Hilltops of the underlying Yap and Map (Maap) Formations protrude through the volcanic deposits in central Gagil-Tamil and on southern and northern Yap Island. 
The Tomil (Tamil) Volcanics are mostly deeply weathered to a kaolinitic clay. The clays generally are deeply eroded because they support only sparse vegetation and central Gagil-Tamil is a wasteland of bare slopes and gullies; some of the gullies are 50 feet deep, entirely in clay. Such erosion is not as well developed on Maap and southern Yap Island, but bare slopes and washes are common.

"Most alluvial deposits are restricted to beaches, because most streams on Yap are narrow with steep gradients and, therefore, have no flood plains of alluvium. Only near the shore, where the streams flow at or near sea level does stream alluvium accumulate to any great amount; in such places it is mixed with sand blown and washed in from the beach. The largest accumulations of alluvium are on the southern tip of Yap Island, northwestern Yap Island, the eastern side of Gagil-Tomil, and on the east and north shores of Map.

"Mangrove swamps discontinuously border the shores of all the islands of Yap. Sandy black muck is deposited in the swamps. The muck is thick and soft where the water circulation in the swamp is very sluggish as along the shores of Tomil Harbor; it is thinner, more sandy, and much more firmly packed where water circulation is rapid, as in swamps along shores exposed to winds and the sea."

\section{Water-Bearing Characteristics}

"The bedrock of Yap is dense and fractures are tight or are filled with clay; the rock has very low permeability and contains little water. It is unsuited for development of water supplies by means of wells. The only practical means of developing supplies are shallow dug wells, wellpoints driven in the alluvium, or seep development. Most streams are fed by seeps from along the banks, rather than from springs.

"The best locations for dug wells or wellpoints in the alluvium of coastal flats are along the inland margins of the wider flats. Wells in such locations are more likely to contain fresh water, and they have the least tidal fluctuation. Wells near the shoreline or on narrow flats are likely to produce brackish water, and the water levels will fluctuate almost as much as the tidal range." 
WATER RESOURCES

\section{General}

The systematic collection of water-resources information was begun in March 1968 when five gaging stations were constructed on Yap Island and one on GagilTamil. Additionally, nine low-flow partial-record stations were established (fig. 5). At the end of 1974, the gaging station on Gagil-Tamil was moved from Gilaew Spring to the principal water source on the island, Mukong Stream. In April 1979, the gaging station at Taalgum Stream, Yap, was discontinued and was relocated in December 1981 on Qatliw Stream, Yap. Also in December 1981, the Daloelaeb Stream, Yap, gaging station was moved to Eyeb Stream, Gagil-Tamil.

At gaging stations (figs. 6, 7), continuous records of gage height are obtained and from these records daily, monthly and annual discharge totals are computed. Daily figures of discharge can be found in the Geological Survey publications or obtained from the Honolulu District office and the Guam Subdistrict office.

Because the number of streams on which streamflow information is likely to be needed far exceeds the number of stream-gaging stations feasible to operate at one time, the Geological Survey collects limited streamflow data at sites other than gaging stations. When limited streamflow data are collected on a systematic basis over a period of years for use in hydrologic analyses, the site at which the data are collected is called a partial-record station. Discharge measurements made at partial-record stations in the Yap Islands are listed in the Hydrologic Data section, tables 37-47. Discharge measurements made at sites not included in the partial-record program are called measurements at miscellaneous sites (table 48).

Since 1979, water samples have been collected by the Geological Survey at 23 sites for chemical analyses. No systematic collection of ground-water data has been made, but in 1979 a number of exploratory wells were drilled and pumping tests were made (Lyon Associates, 1980). In 1982, 13 production wells were drilled and pumping tests made (Nance, 1982).

Prior to 1968, virtually no water-resources data were available except for rainfall data. 


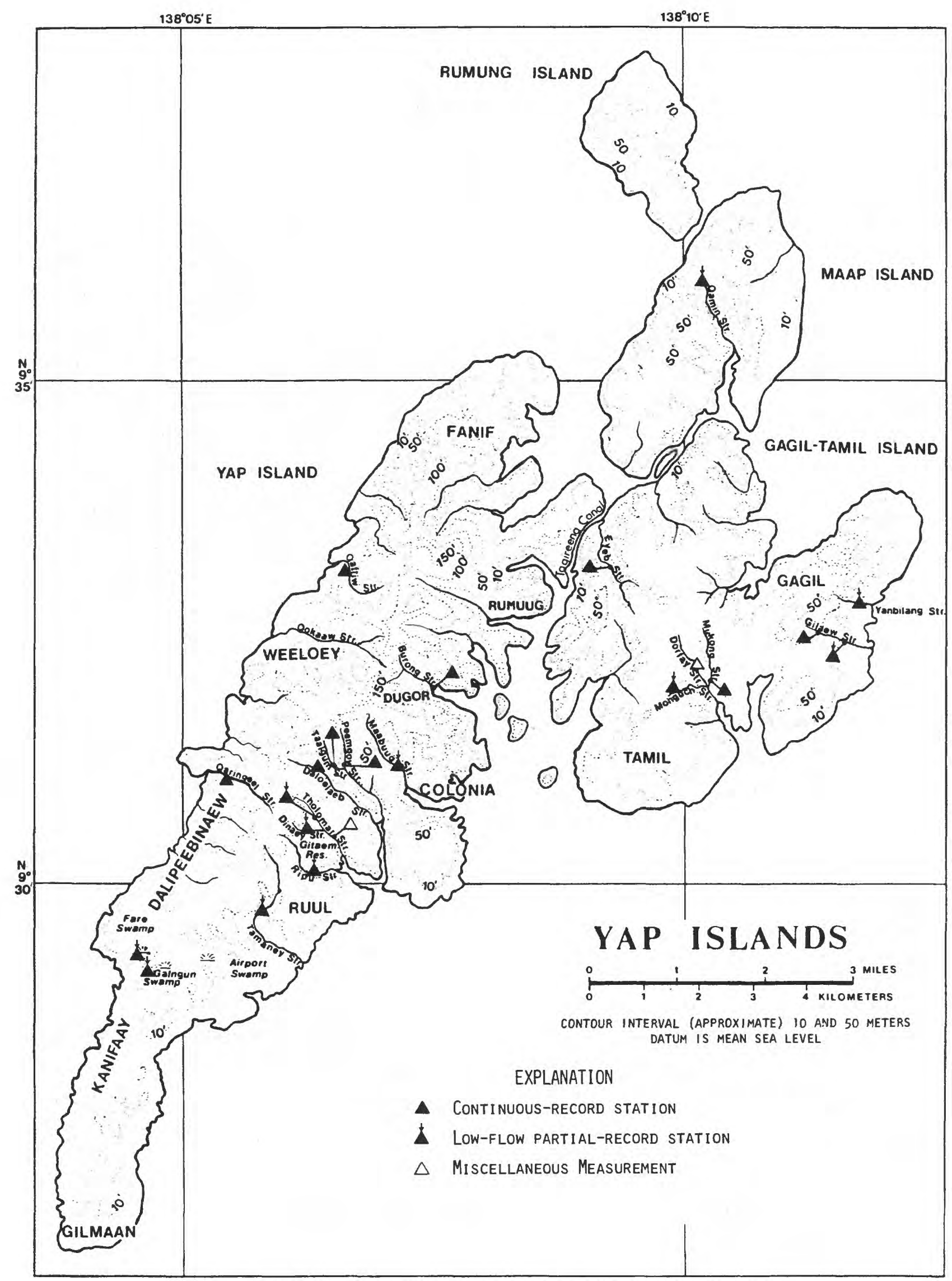

Figure 5. LOCATION OF SURFACE-WATER DATA-COLLECTION SITES. 


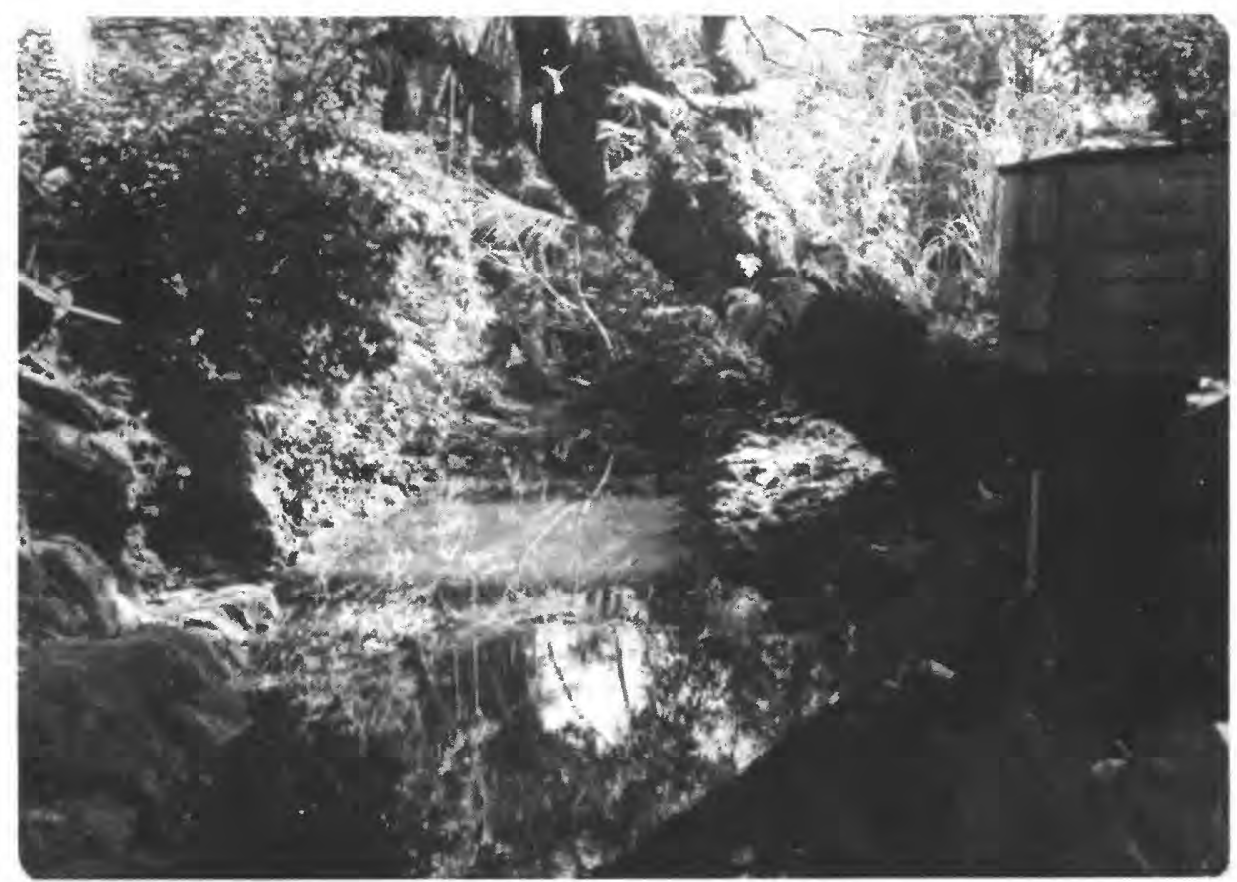

Figure 6. Downstream view of gaging station on Mukong Stream, Gagil-Tami1.

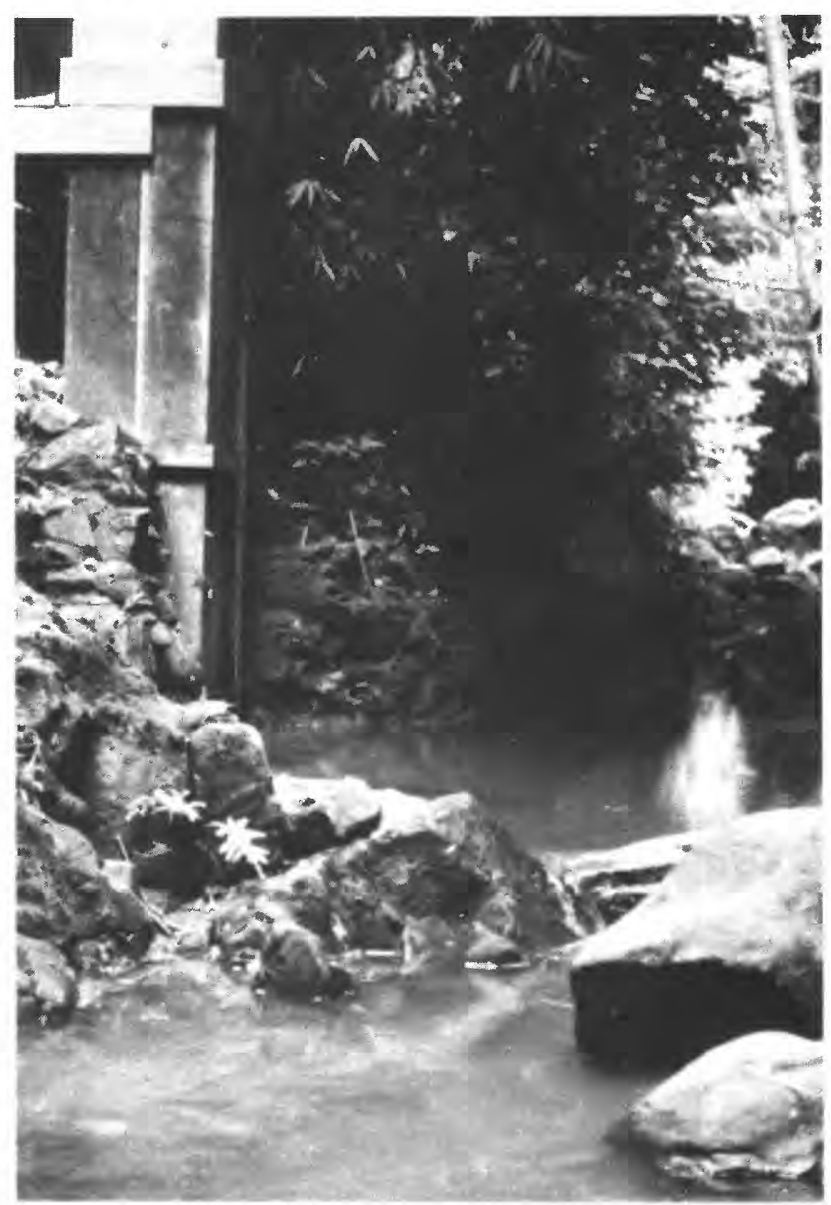

Figure 7. Upstream view of gaging station on Qaringeel Stream, Yap. 


\section{Surface Water}

\section{General}

Although the Yap Islands have an average yearly rainfall of 122 inches, there are no perennial streams on the Island of Yap where all streams usually will be dry during part of the dry season, ranging from a few days to several months. The largest stream in yearly discharge, Qaringeel Stream, has been dry an average of 10 weeks a year during 1969-82. The streams go dry because they have small drainage areas (only a few exceed a quarter of a square mile) and the water retention of the soil and rock of their watershed is low. The principle geologic formation of the drainage areas of all Yap streams is the green schist of the Yap Formation of Tayama (1935).

On Gagil-Tamil, the geologic formation is quite different (see fig. 4 ). There, Mukong Stream and adjacent streams in the central valley are not known to go dry. The principal geologic formation is the deeply weathered Tomil (Tamil) Volcanics of Tayama (1935), which allows greater infiltration of rainfall, and subsequent release to the streams during long periods of dry weather. Additionally, the drainage area of Mukong Stream is much larger than any stream on Yap Island. The different character of the flow of Mukong Stream compared to that of the Yap stations is illustrated by the flow-duration curves of figure 8 .

Table 3 lists the streams and locations where flow data have been collected. As an added means of identification, each gaging station and partial-record station has been assigned a station number. In assigning the numbers, no distinction is made between partial-record and continuous-record gaging stations. Gaps are left in the numbers to allow for new stations that may be established. This numbering system is used nationwide. 


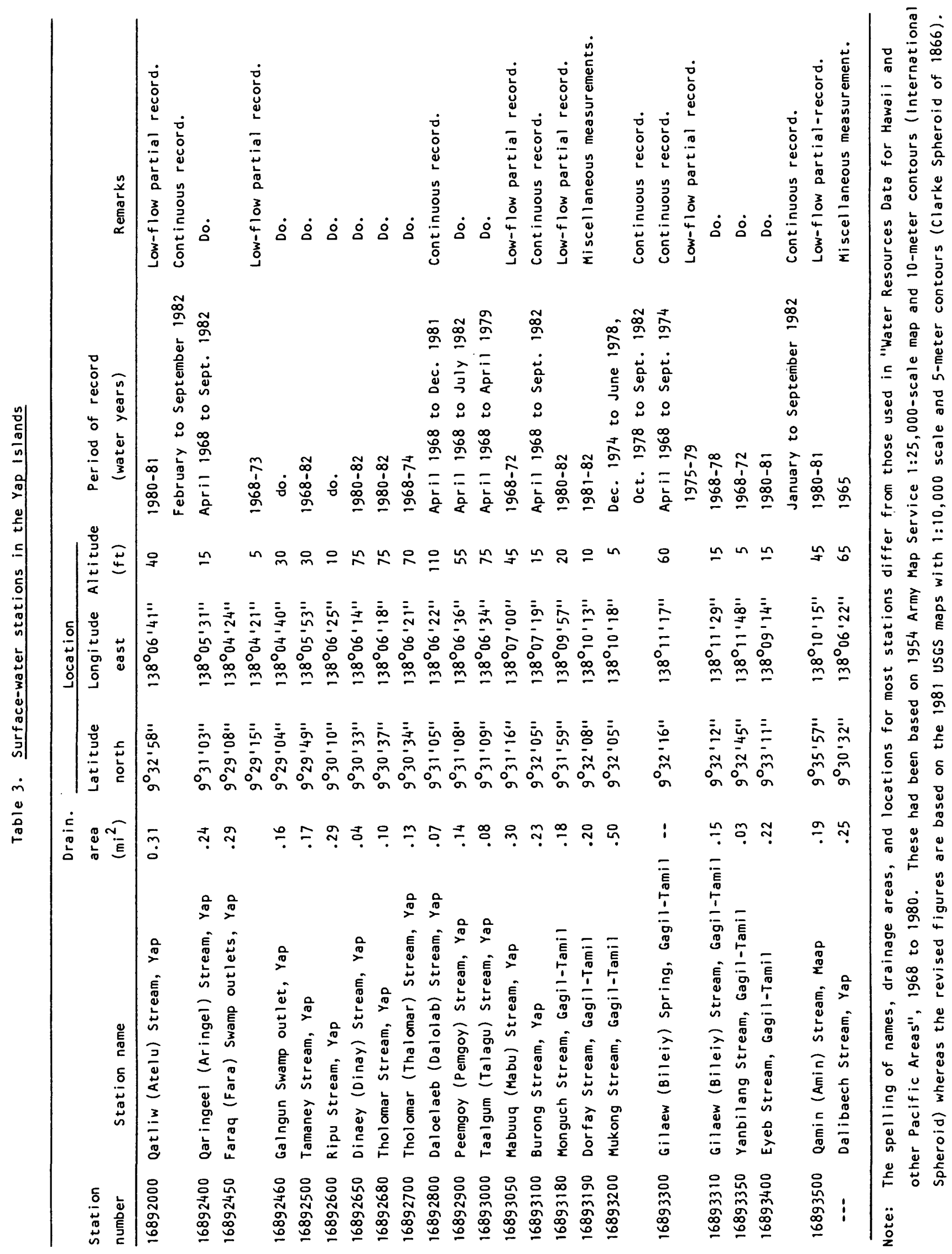


Data collected at continuous-record stations consist of records of stage and measurements of discharge of the streams. Records of stage are obtained from a water-stage recorder that provides a continuous graph of the fluctuations of the water level at the station site. Measurements of discharge are made with a current meter.

For continuous-record stations, rating tables giving the discharge for a range of stage (gage height) are prepared from stage-discharge relation curves defined by the discharge measurements at the stations. Application of the daily mean stage to the rating table gives the daily mean discharge from which the monthly and the yearly mean discharges are computed. These records are published in the annual reports, "Water Resources Data for Hawai i and other Pacific Areas", for the water year, which begins on 0ctober 1 and ends on September 30 .

Tables with monthly and annual totals, annual maximums, minimums, and means are presented in the Hydrologic Data section. Peak discharges and their times of occurrence and corresponding gage heights are listed for all peaks above a selected base discharge are given. The base discharge is selected so that an average of about three peaks a year can be presented. Time is expressed in 24hour local standard time.

At the partial-record sites only low-flow data are collected. Most measurements are made during periods of base flow, when streamflow is primarily from ground-water storage. These measurements, when correlated with the simultaneous discharge of a nearby stream where continuous records are available, will provide an estimate of the low-flow potential of the partial-record site.

A comparison of the monthly yields from gaged streams on Yap and Gagil-Tamil is provided in table 4. The table also lists the percentage of days without flow for each month. The annual percentage of " 0 " flow days varies for the Yap stations from 14 percent at Peemgoy Stream to 38 percent at Daloelaeb Stream and averages 26 percent, which is more than 3 months of the year. 


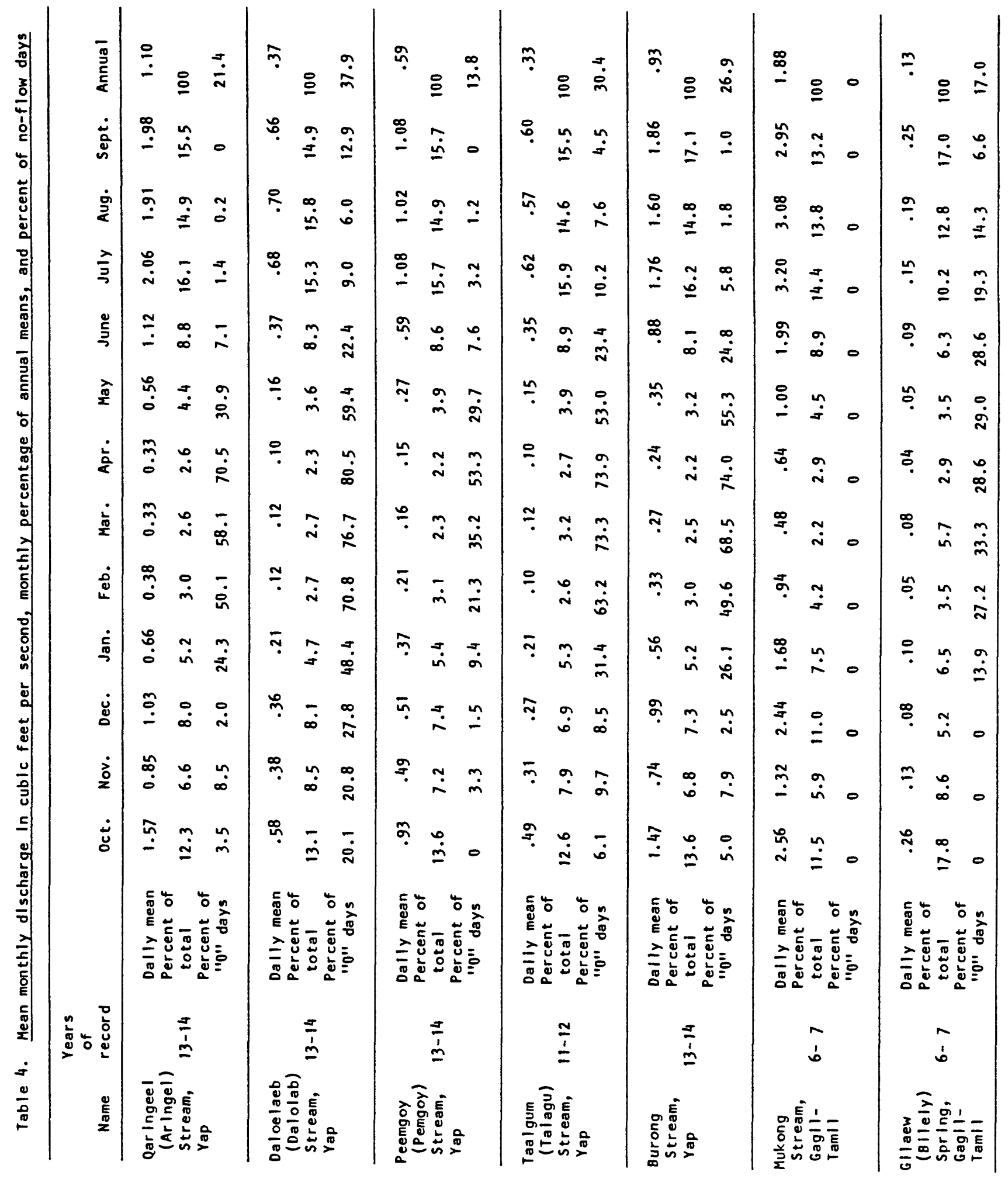


Streamflow characteristics

Rainfall-runoff relations.--Annual rainfall totals from the National Weather Service station at the Yap Airport (table 19) are used for all rainfallrunoff calculations.

The data in table 5 indicate that on Yap Island about half the annual rainfall runs off as streamflow. As most streams on Yap are dry during much of January to May, table 6 was compiled to determine the rainfall-runoff ratio only during the wet months, June to December, for comparison with the yearly ratio. The table shows that during the wet season, the mean percentage of direct runoff of Yap stations is only 7 percent higher than the yearly runoff percentage.

Because the average yearly rainfall for the 13-year period (1969-81) used for the rainfall-runoff ratio is 120.11 inches, and the long-term (1949-81) average is 121.30 inches, the rainfall totals for the 13 -year period can be considered representative of average conditions.

For better comparison between the Yap stations and Mukong Stream, the average percentage of runoff was also computed for only those years when complete records were available for both (tables 5 and 6 ). This showed that the annual percentage of runoff was practically the same. For the wet months, June to December, the average runoff of the Yap stations was 9 percent higher than for Mukong Stream, indicating that on Gagil-Tamil more rainfall became infiltration than on Yap.

A confirmation of the uniformity of the rainfall in the Yap Islands and the rainfall-runoff relationship of the streams on Yap is the similarity of the regression correlations of the annual runoff at Qaringeel Stream with the rainfall at Yap Airport, $Y=0.024 \times 1.64$, and of the annual runoff " of Burong Stream with the Yap Airport rainfall, $Y=0.026 \times 1.60$, where $Y$ is the runoff and $X$ is the rainfall. 


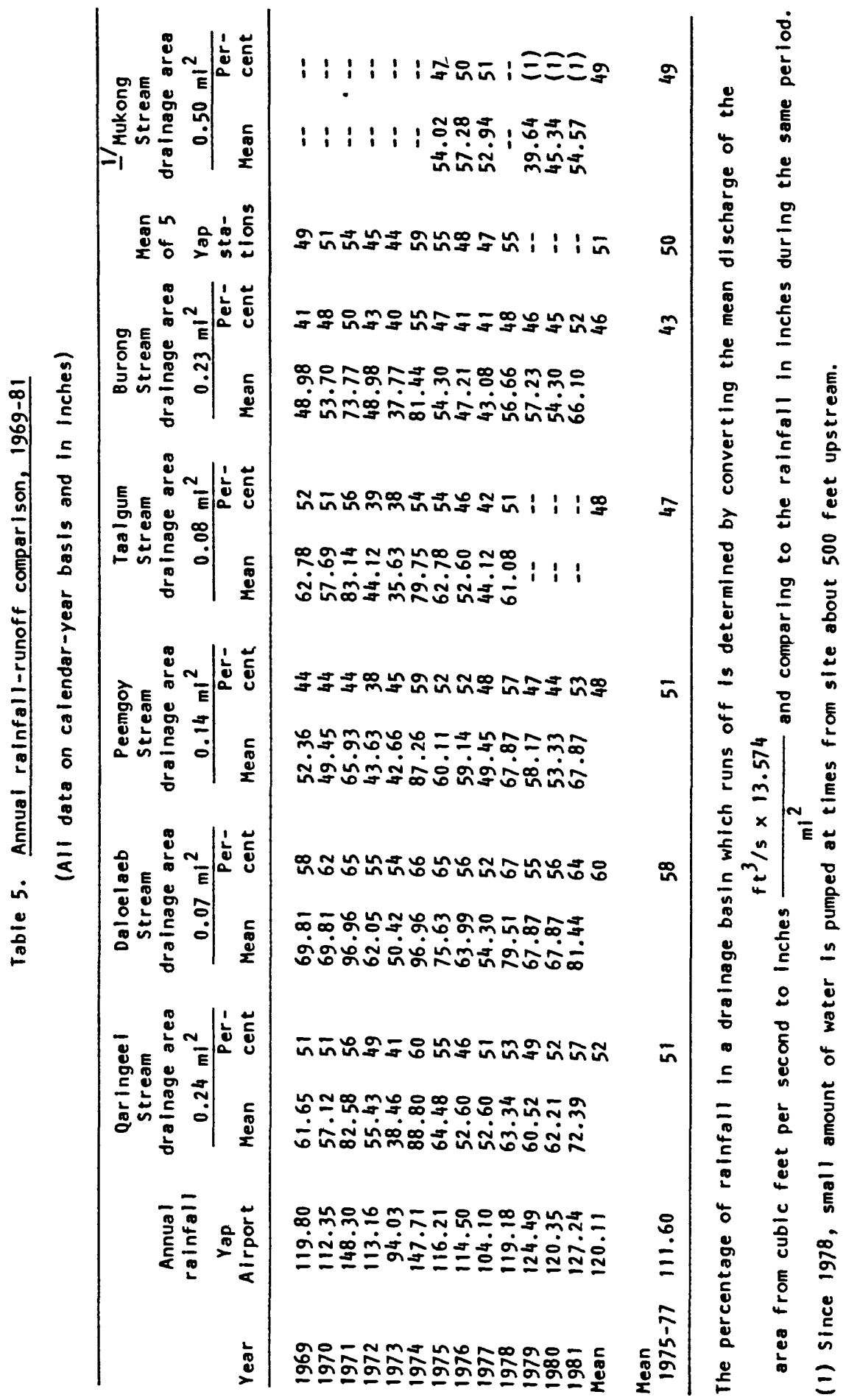




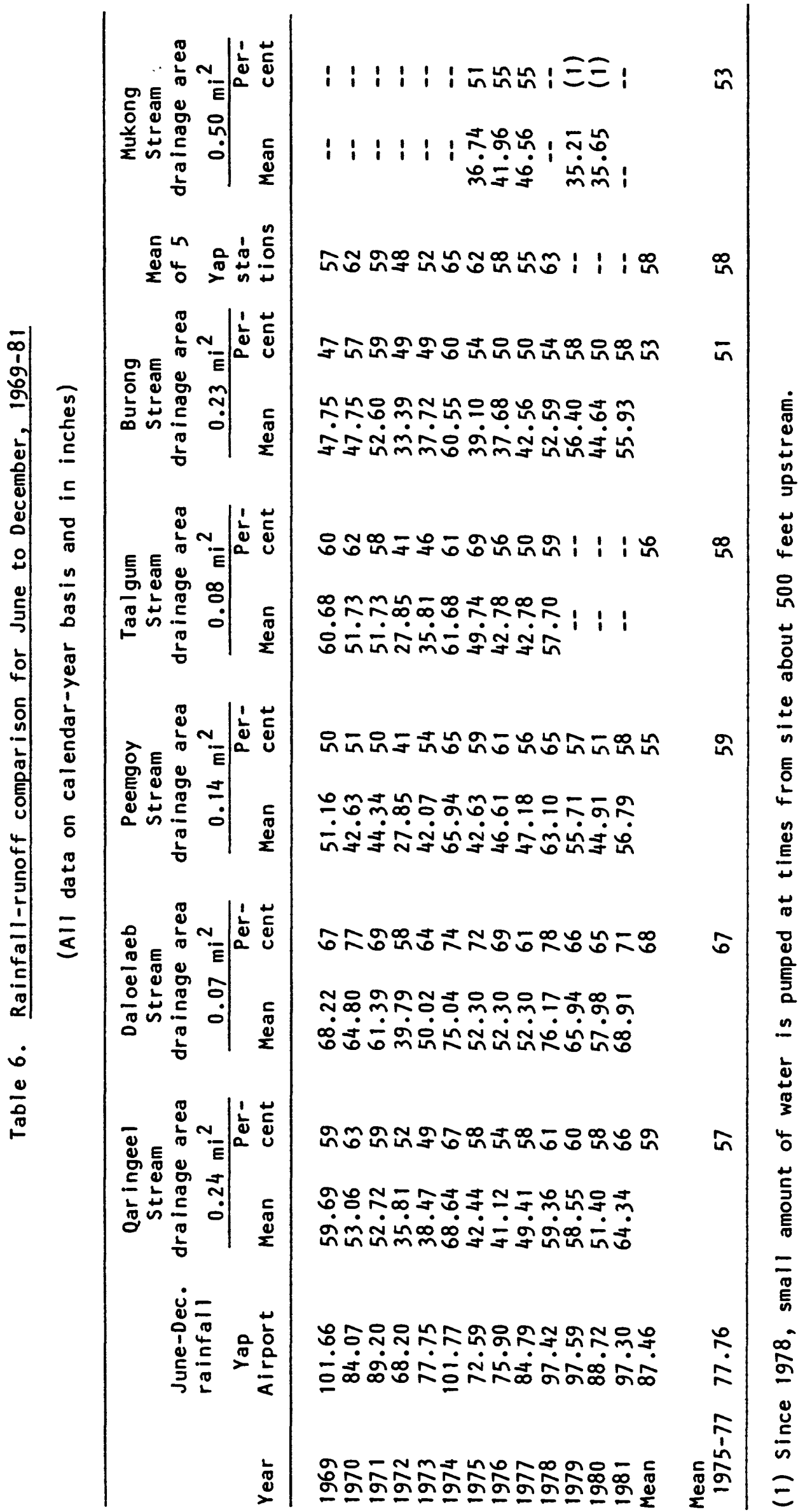


Flow-duration curves.--A flow-duration curve is a cumulative frequency curve showing the percentage of time within the total period of record that a specified daily discharge was equaled or exceeded. It combines in one curve the flow characteristics of a stream throughout the range of discharge without regard to the sequence of occurrence. The general shape of such a curve is influenced by many factors, such as basin slope and cover, ground-water contributions, precipitation, and diversions or inflows.

The curve is plotted from a flow-duration table, which shows the distribution of daily discharge by different class limits in increasing order of magnitude. Discharge in cubic feet per second is plotted on the ordinate and percent-of-time equaled or exceeded is plotted on the abscissa. The flowduration tables in this report are based on distribution of the daily discharge.

For comparison of the curves for different streams, data covering the same period should be used to avoid including an extremely dry or wet year in one set and not in the other.

Flow-duration curves are used to determine the percent of time that a certain amount of water was available during the period of record. This information is essential for planning of stream diversions for water supply or to assess hydroelectric potential.

The flow-duration curves for four streams on Yap and one on Gagil-Tamil are given in figure 8 . The streams, their drainage area, and the period of record are:

$\begin{array}{lrc} & \begin{array}{c}\text { Area } \\ \left(\mathrm{mi}^{2}\right)\end{array} & \begin{array}{c}\text { Years } \\ \text { of record }\end{array} \\ \text { Qaringeel Stream, Yap } & 0.24 & 11 \\ \text { Daloelaeb Stream, Yap } & .07 & 11 \\ \text { Peemgoy Stream, Yap } & .14 & 11 \\ \text { Burong Stream, Yap } & .23 & 11 \\ \text { Mukong Stream, Gagil-Tamil } & .50 & 3\end{array}$

The duration curve for Taalgum Stream, Yap, for which 10 years of data are available, is not plotted because the curve is almost identical to the one of Daloelaeb Stream. 


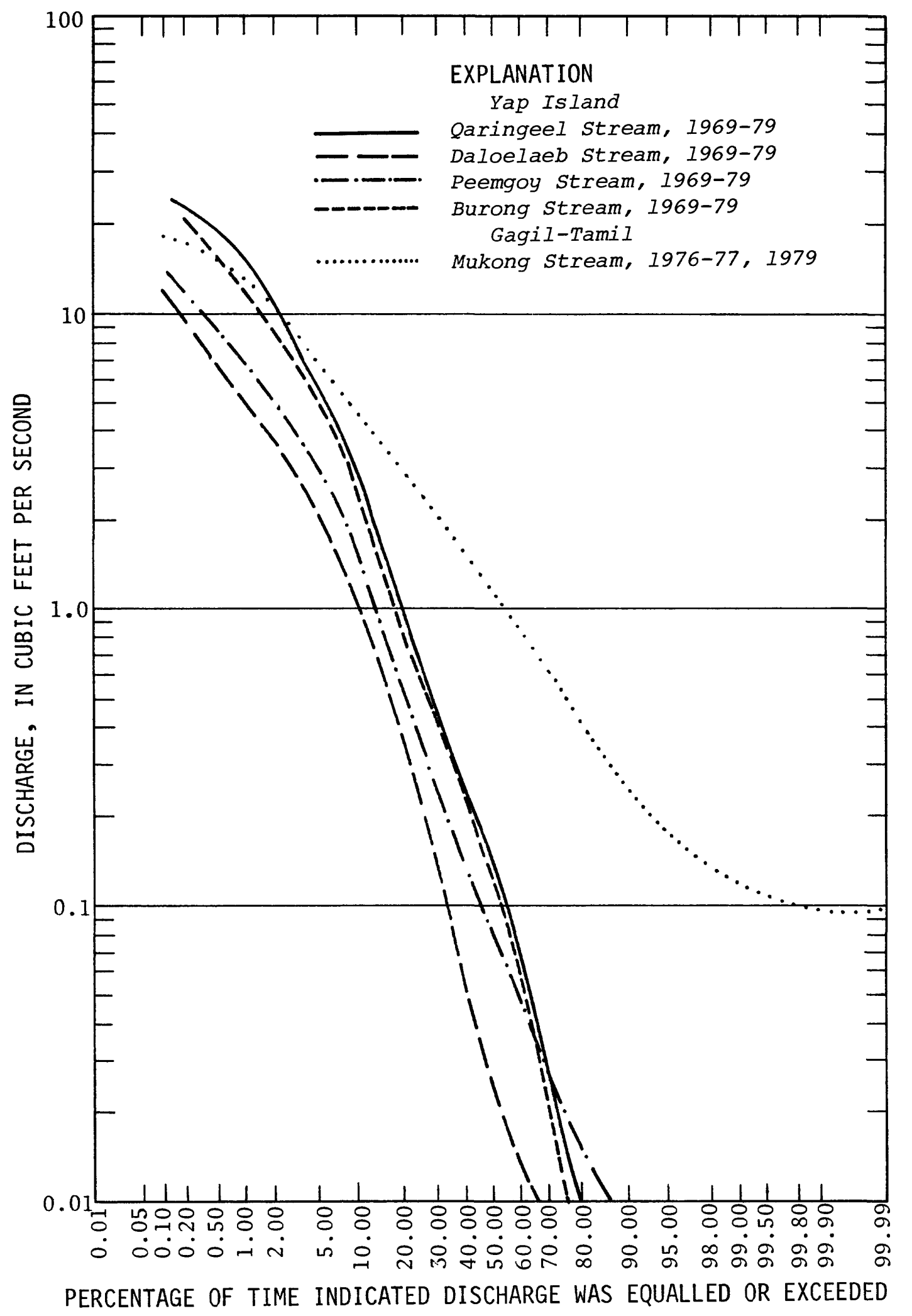

Figure 8. Flow-duration curves of four streams on Yap Island and one on Gagil-Tamil. 
The similarity of the duration curves of all five Yap stations shows the comparability of their drainage areas; the only exception being Peemgoy Stream with some retention of rainfall in the watershed. This retention is also indicated by Peemgoy Stream having the fewest number of days without flow.

Only 3 years of complete record without diversion of some of the flow are available for Mukong Stream on Gagil-Tamil, but the mean rainfall during these 3 years differs by only 1 percent from the mean rainfall during the 11-year period used for the Yap streams. The contrast between the curves indicates a difference in the geology of the drainage areas as described previously.

Low-flow frequency tables.--Low-flow tables show the lowest mean discharge for certain periods of consecutive days. Because all Yap streams have no flow during part of the dry season, low-flow frequency curves would not be very meaningful and only the tables are provided (table 7).

For Mukong Stream, Gagil-Tamil, only a few years of complete record are available and this station is not included in the table.

High-flow frequency curves.--High-flow frequency curves show the maximum mean discharge for certain periods of consecutive days and its likelihood of occurrence. These curves can also be used to show the frequency of instantaneous annual peak discharge.

Figures 9-13 show the recurrence intervals of the maximum mean discharge for six periods of consecutive days for the five continuous-record stations on Yap Island. The period of record for the continuous-record stations on Gagil-Tamil was of insufficient length to be used for frequency curves. The uniformity of the curves for the Yap stations show the similarity of their basins.

Figure 14 shows the magnitude and frequency of annual and instantaneous peak flows for four continuous-record stations on Yap with 11 years of complete record.

High-flow frequency curves provide information needed to determine the size of reservoirs and diversion structures.

Frequency curves for annual peak flows are needed to size and design storm drainage systems, culverts and bridge openings. 
Table 7. Lowest mean value for a number of consecutive days for years ending September 30

(Discharge in cubic feet per second)

\begin{tabular}{llllllll}
\hline & \multicolumn{7}{c}{ Days } \\
\cline { 2 - 7 } Year & 1 & 7 & 14 & 30 & 60 & 90 & 120 \\
\hline
\end{tabular}

Qaringeel Stream, Yap

$\begin{array}{llllllll}1969 & 0 & 0 & 0 & 0 & 0 & 0 & 0.01 \\ 1970 & 0 & 0 & 0 & 0 & .05 & .12 & .19 \\ 1971 & .01 & .03 & .13 & .50 & .81 & .80 & .92 \\ 1972 & 0 & 0 & 0 & .03 & .06 & .26 & .48 \\ 1973 & 0 & 0 & 0 & 0 & 0 & 0 & 0 \\ 1974 & 0 & 0 & 0 & .07 & .21 & .34 & .56 \\ 1975 & 0 & 0 & 0 & 0 & 0 & .01 & .34 \\ 1976 & 0 & 0 & 0 & 0 & .06 & .08 & .24 \\ 1977 & 0 & 0 & 0 & 0 & 0 & 0 & .01 \\ 1978 & 0 & 0 & 0 & 0 & 0 & 0 & 0 \\ 1979 & 0 & 0 & 0 & 0 & 0 & .06 & .05 \\ 1980 & 0 & 0 & 0 & 0 & .06 & .23 & .29\end{array}$

Daloelaeb Stream, Yap

\begin{tabular}{|c|c|c|c|c|c|c|c|}
\hline 1969 & 0 & 0 & 0 & 0 & 0 & 0 & 0 \\
\hline 1970 & 0 & 0 & 0 & 0 & .01 & .03 & .05 \\
\hline 1971 & 0 & 0 & .02 & .17 & .23 & .23 & .27 \\
\hline 1972 & 0 & 0 & 0 & .01 & .02 & .07 & .16 \\
\hline 1973 & 0 & 0 & 0 & 0 & 0 & 0 & 0 \\
\hline 1974 & 0 & 0 & 0 & 0 & .05 & .09 & .17 \\
\hline 1975 & 0 & 0 & 0 & 0 & 0 & 0 & .08 \\
\hline 1976 & 0 & 0 & 0 & 0 & .02 & .03 & .08 \\
\hline 1977 & 0 & 0 & 0 & 0 & 0 & 0 & .01 \\
\hline 1978 & 0 & 0 & 0 & 0 & 0 & 0 & 0 \\
\hline 1979 & 0 & 0 & 0 & 0 & 0 & .02 & .02 \\
\hline 1980 & 0 & 0 & 0 & 0 & 0 & .08 & .08 \\
\hline \multicolumn{8}{|c|}{ Peemgoy Stream, Yap } \\
\hline 1969 & 0 & 0 & 0 & 0 & 0 & 0 & 0.01 \\
\hline 1970 & 0 & 0 & 0 & 0 & .02 & .08 & .11 \\
\hline 1971 & .01 & .02 & .05 & .18 & .32 & .31 & .37 \\
\hline 1972 & 0 & 0 & 0 & .01 & .03 & .10 & .21 \\
\hline 1973 & 0 & 0 & 0 & 0 & 0 & 0 & 0 \\
\hline 1974 & 0 & 0 & 0 & .02 & .11 & .20 & .34 \\
\hline 1975 & 0 & 0 & 0 & 0 & .01 & .03 & .14 \\
\hline 1976 & 0 & 0 & .01 & .01 & .04 & .05 & .12 \\
\hline 1977 & 0 & 0 & 0 & 0 & 0 & 0 & .02 \\
\hline 1978 & 0 & 0 & .01 & .01 & .01 & .01 & .03 \\
\hline 1979 & 0 & .01 & .01 & .01 & .01 & .04 & .01 \\
\hline 1980 & 0 & 0 & 0 & .01 & .02 & .11 & .1 \\
\hline
\end{tabular}


Table 7. Lowest mean value for a number of consecutive days for years ending September 30--Continued

( $D$ ischarge in cubic feet per second)

\begin{tabular}{|c|c|c|c|c|c|c|c|}
\hline \multirow[b]{2}{*}{ Year } & \multicolumn{7}{|c|}{ Days } \\
\hline & 1 & 7 & 14 & 30 & 60 & 90 & 120 \\
\hline \multicolumn{8}{|c|}{ Taalgum Stream, Yap } \\
\hline 1969 & 0 & 0 & 0 & 0 & 0 & 0 & 0.01 \\
\hline 1970 & 0 & 0 & 0 & 0 & 0 & .03 & .04 \\
\hline 1971 & .01 & .01 & .03 & .12 & .26 & .25 & .28 \\
\hline 1972 & 0 & 0 & 0 & .01 & .02 & .06 & .13 \\
\hline 1973 & 0 & 0 & 0 & 0 & 0 & 0 & 0 \\
\hline 1974 & 0 & 0 & 0 & 0 & .05 & .10 & .18 \\
\hline 1975 & 0 & 0 & 0 & 0 & 0 & .01 & .07 \\
\hline 1976 & 0 & 0 & 0 & 0 & .02 & .03 & .07 \\
\hline 1977 & 0 & 0 & 0 & 0 & 0 & 0 & .01 \\
\hline 1978 & 0 & 0 & 0 & 0 & 0 & 0 & 0 \\
\hline \multicolumn{8}{|c|}{ Burong Stream, Yap } \\
\hline 1969 & 0 & 0 & 0 & 0 & 0 & 0 & 0 \\
\hline 1970 & 0 & 0 & 0 & 0 & .01 & .07 & .11 \\
\hline 1971 & .01 & .03 & .06 & .39 & .59 & .64 & .71 \\
\hline 1972 & 0 & 0 & 0 & .02 & .05 & .13 & .36 \\
\hline 1973 & 0 & 0 & 0 & 0 & 0 & 0 & 0 \\
\hline 1974 & 0 & 0 & 0 & .02 & .20 & .38 & .54 \\
\hline 1975 & 0 & 0 & 0 & 0 & 0 & .01 & .15 \\
\hline 1976 & 0 & 0 & 0 & 0 & .04 & .05 & .13 \\
\hline 1977 & 0 & 0 & 0 & 0 & 0 & 0 & 0 \\
\hline 1978 & 0 & 0 & 0 & 0 & 0 & 0 & .01 \\
\hline 1979 & 0 & 0 & 0 & 0 & 0 & .03 & .03 \\
\hline 1980 & 0 & 0 & 0 & 0 & .02 & .21 & .26 \\
\hline
\end{tabular}




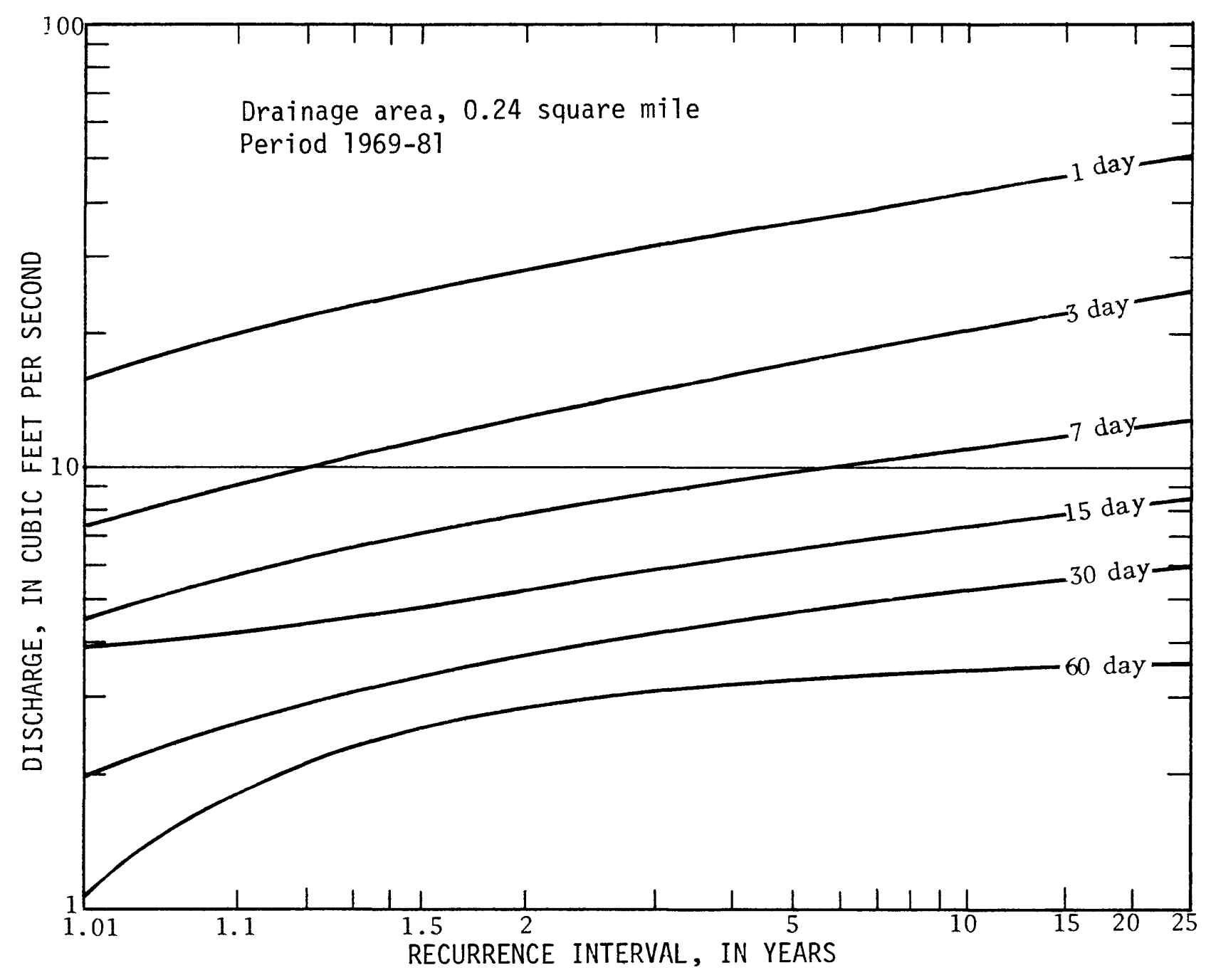

Figure 9. Magnitude and frequency of highest mean discharge for duration indicated. Qaringeel Stream, Yap. 


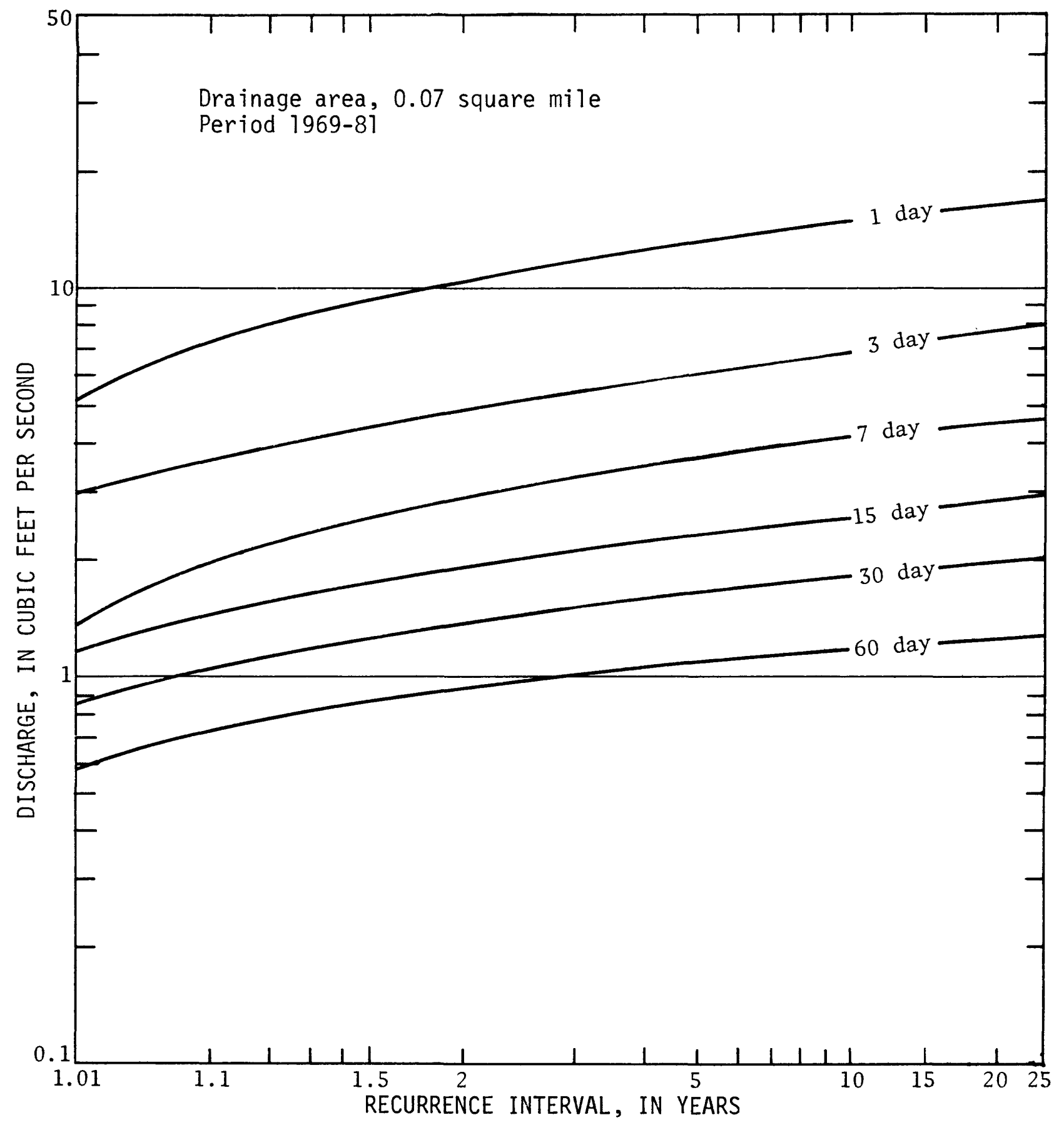

Figure 10. Magnitude and frequency of highest mean discharge for duration indicated. Daloelaeb Stream, Yap. 


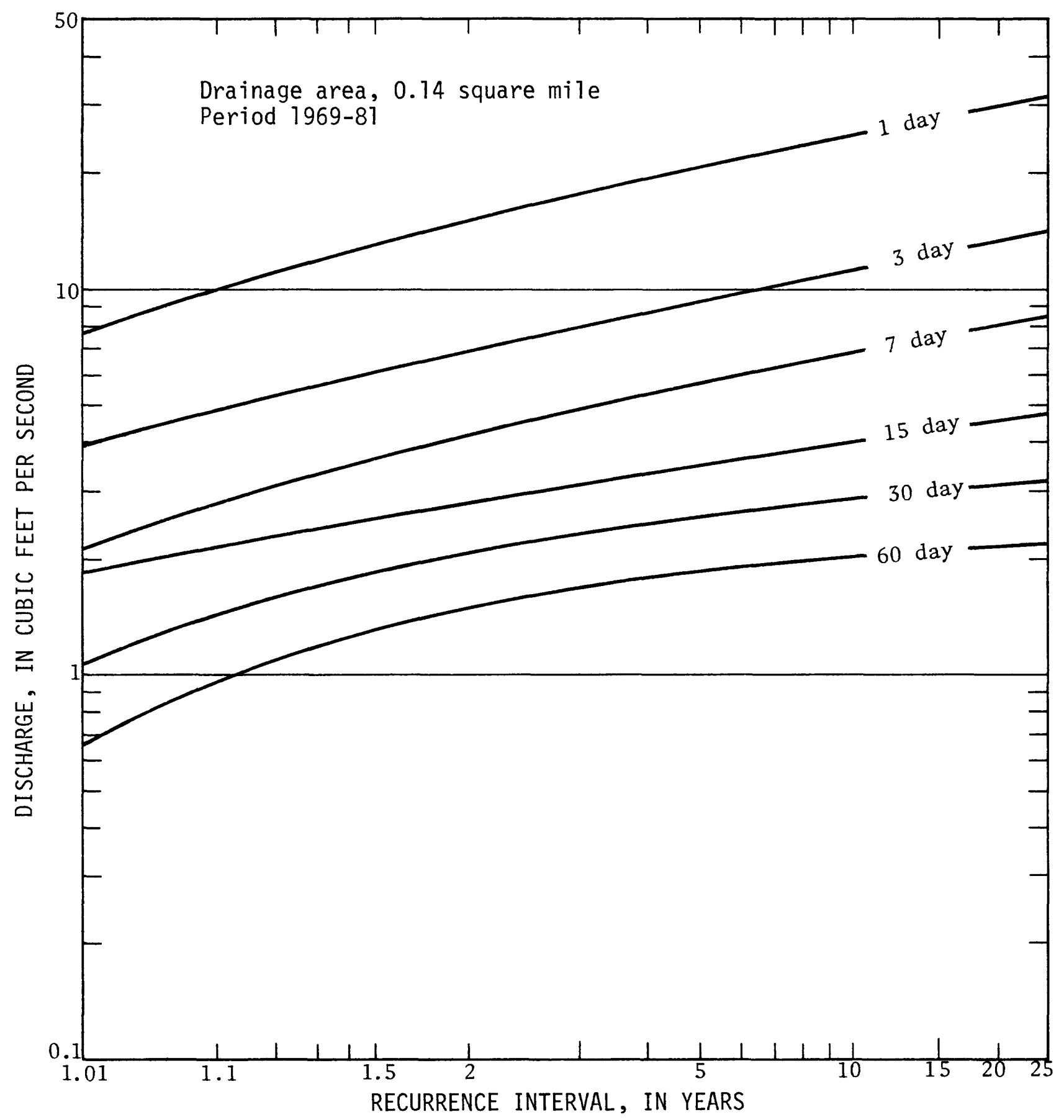

Figure 11. Magnitude and frequency of highest mean discharge for duration indicated. Peemgoy Stream, Yap. 


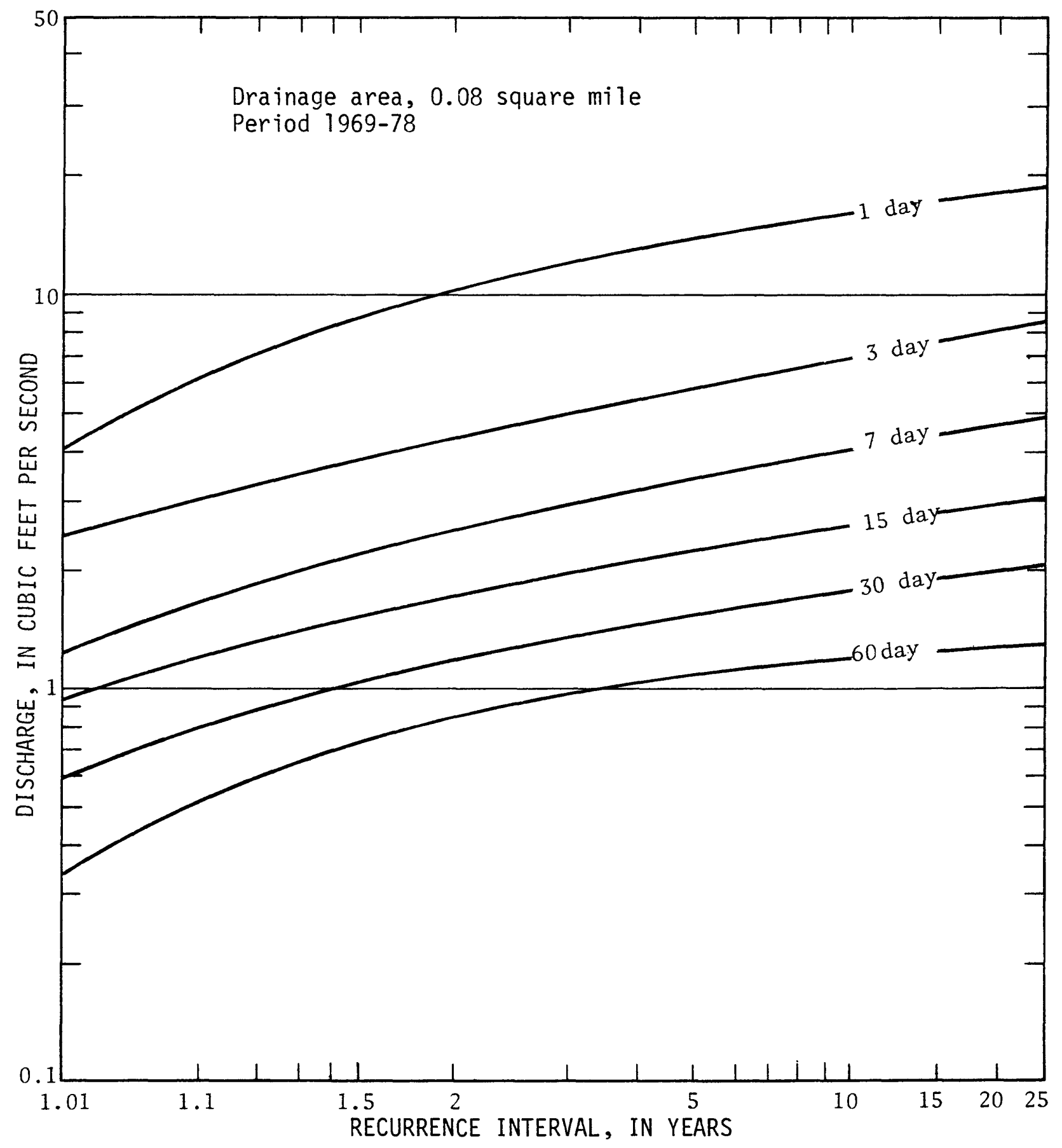

Figure 12. Magnitude and frequency of highest mean discharge for duration indicated. Taalgum Stream, Yap. 


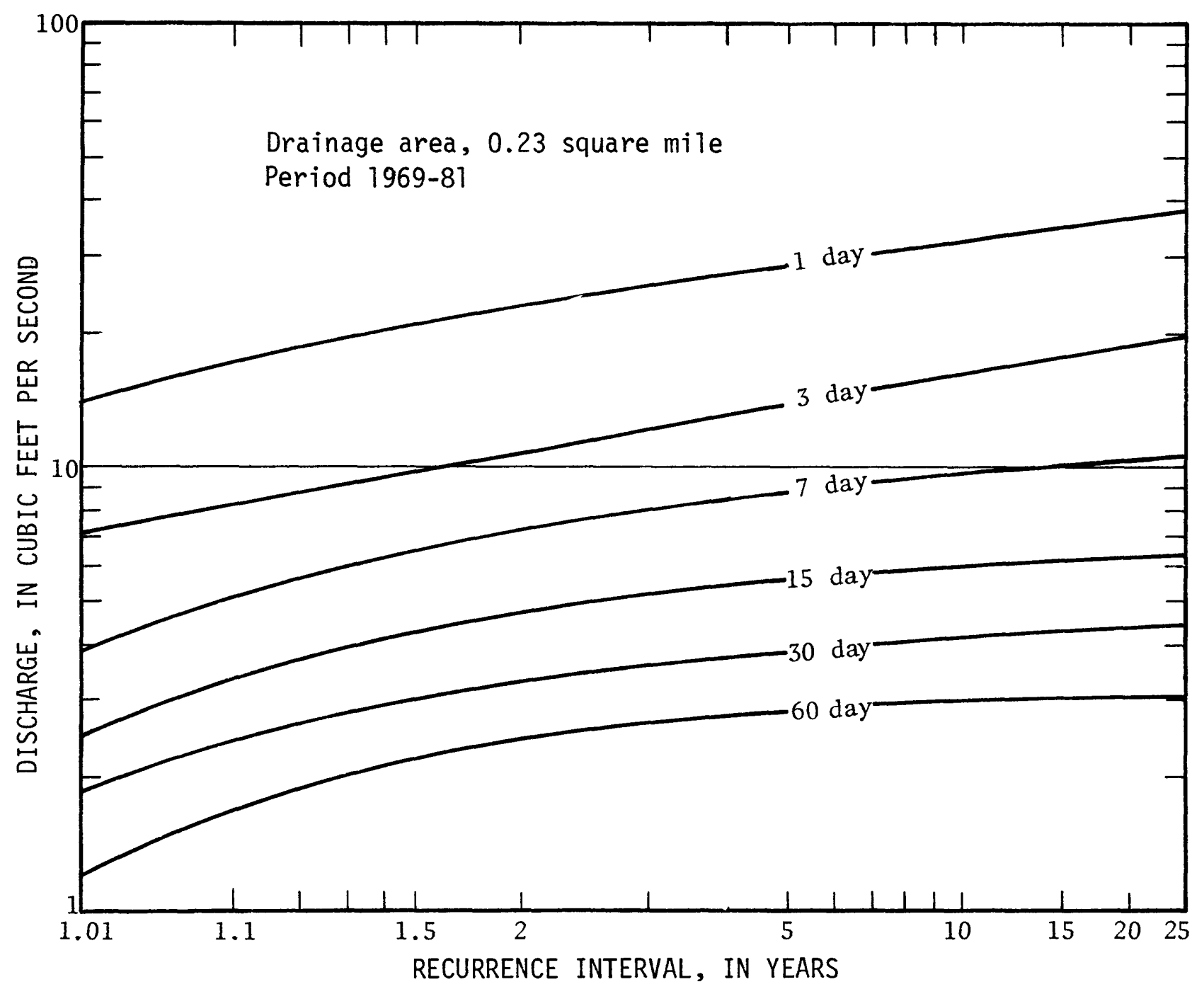

Figure 13. Magnitude and frequency of highest mean discharge for duration indicated. Burong Stream, Yap. 


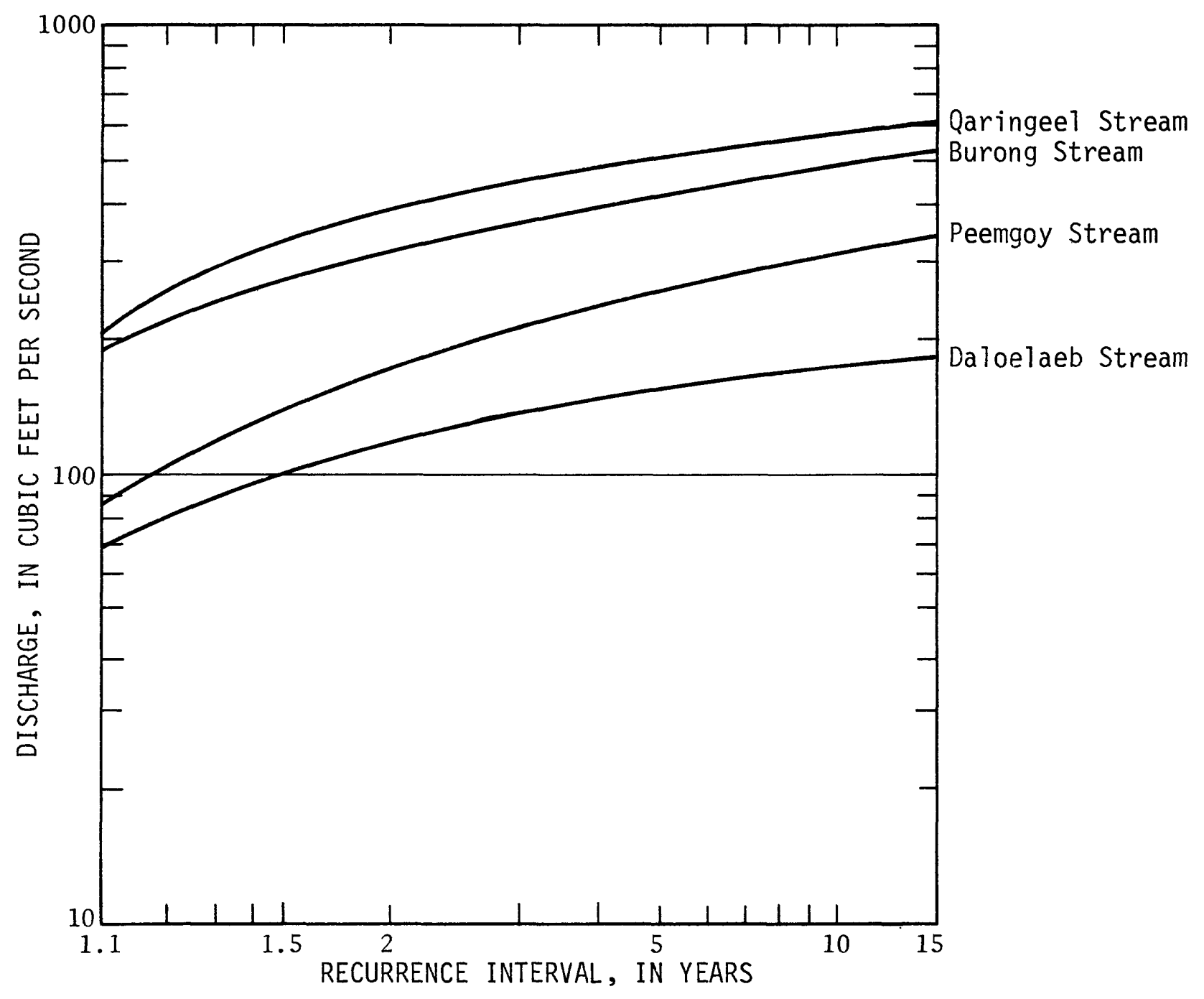

Figure 14. Magnitude and frequency of annual and instantaneous peak flows for four continuous-record stations on Yap Island, 1969-79. 
Correlation of partial record with continuous record

A low-flow partial-record station is operated to determine the low-flow characteristics of a stream through correlation with concurrent discharges at continuous-record gaging stations.

The discharge measurements of five partial-record stations were correlated with discharge records for nearby gaging stations (table 8). Because Mabuuq Stream, is nearly equidistant from Peemgoy and Burong Streams, a correlation with both streams was made, and this yielded almost identical results. The correlation with Burong Stream was selected because of the better correlation coefficient and lower standard error.

Discharge measurements for all partial-record stations could not be correlated with discharges at continuous-record stations because flow characteristics of Faraq and Galngun Swamp outlets differ from those of the continuousrecord stations and discharge of Yanbilang Stream, Gagil-Tamil proved to be too small for correlation.

Figures 15-19 show the regression lines of the five partial-record stations. From these lines, a reasonable estimate of low flows can be made using the known discharge of the nearest continuous-record station.

\section{Historical and existing developments}

Because of the prolonged dry season, normally from January to May, the limited quantity of rain stored as ground water, and the small drainage areas, all streams on Yap Island are dry part of the year. As a consequence, there is a need for surface-water storage. The first storage dam was built on Tamaney Stream during the German Administration. This earthen dam, about 8 feet high and 100 feet long at an altitude of about 25 feet, was built to store water primarily for a communication station and a nearby German settlement. The center of the dam was subsequently washed out by floodflows. Local residents say that the reservoir wasn't used during the Japanese Administration.

Gitaem was the site of the first central water supply system in Yap. An earthen dam was built across Dalibaech Stream in 1951 with a storage capacity of $2 \mathrm{Mgal}$ (million gallons). Water from the reservoir was distributed by 3-and 4inch galvanized pipes. Later (1965), a treatment plant was installed with a 200gal/min (gallons per minute) capacity. 
Table 8. Correlation between discharges at low-flow partial-record and continuous-record stations

[Y, discharge at partial-record station;

$X$, discharge at continuous-record station]

\begin{tabular}{|c|c|c|c|c|c|c|}
\hline $\begin{array}{l}\text { Partial- } \\
\text { record } \\
\text { station }\end{array}$ & $\begin{array}{l}\text { Drain- } \\
\text { age } \\
\text { area } \\
\text { (square } \\
\text { miles) }\end{array}$ & $\begin{array}{l}\text { Contin- } \\
\text { uous } \\
\text { record } \\
\text { station }\end{array}$ & $\begin{array}{l}\text { Drain- } \\
\text { age } \\
\text { area } \\
\text { (square } \\
\text { miles) }\end{array}$ & $\begin{array}{l}\text { Corre- } \\
\text { lation } \\
\text { coeffi- } \\
\text { cient }\end{array}$ & $\begin{array}{c}\text { Standard } \\
\text { error } \\
\text { in } \\
\text { percent }\end{array}$ & $\begin{array}{l}\text { Regression } \\
\text { equation }\end{array}$ \\
\hline $\begin{array}{l}\text { Tamaney } \\
\text { Stream, } \\
\text { Yap }\end{array}$ & 0.17 & $\begin{array}{l}\text { Qar ingeel } \\
\text { Stream, } \\
\text { Yap }\end{array}$ & 0.24 & 0.93 & 0.12 & $Y=0.702 x^{0.897}$ \\
\hline $\begin{array}{l}\text { Ripu } \\
\text { Stream, } \\
\text { Yap }\end{array}$ & .29 & $\begin{array}{l}\text { Qar ingeel } \\
\text { Stream, } \\
\text { Yap }\end{array}$ & .24 & .95 & .10 & $Y=.844 x^{0.913}$ \\
\hline $\begin{array}{c}\text { Tholomar } \\
\text { Stream, } \\
\text { Yap }\end{array}$ & .13 & $\begin{array}{l}\text { Qar ingeel } \\
\text { Stream, } \\
\text { Yap }\end{array}$ & .24 & .96 & .12 & $Y=1.009 \times 0.899$ \\
\hline \multirow[t]{2}{*}{$\begin{array}{l}\text { Mabuuq } \\
\text { Stream, } \\
\text { Yap }\end{array}$} & .24 & $\begin{array}{l}\text { Peemgoy } \\
\text { Stream, } \\
\text { Yap }\end{array}$ & .14 & .93 & .21 & $Y=1.792 \times 0.895$ \\
\hline & & $\begin{array}{l}\text { Burong } \\
\text { Stream, } \\
\text { Yap }\end{array}$ & .23 & .96 & .14 & $Y=.865 x^{0.870}$ \\
\hline $\begin{array}{l}\text { Gilaew } \\
\text { Stream, } \\
\text { Gagil- } \\
\text { Tamil }\end{array}$ & .15 & $\begin{array}{l}\text { Gilaew } \\
\text { Spring, } \\
\text { Gagil- } \\
\text { Tamil }\end{array}$ & -- & .88 & .17 & $Y=1.819 x^{0.872}$ \\
\hline
\end{tabular}




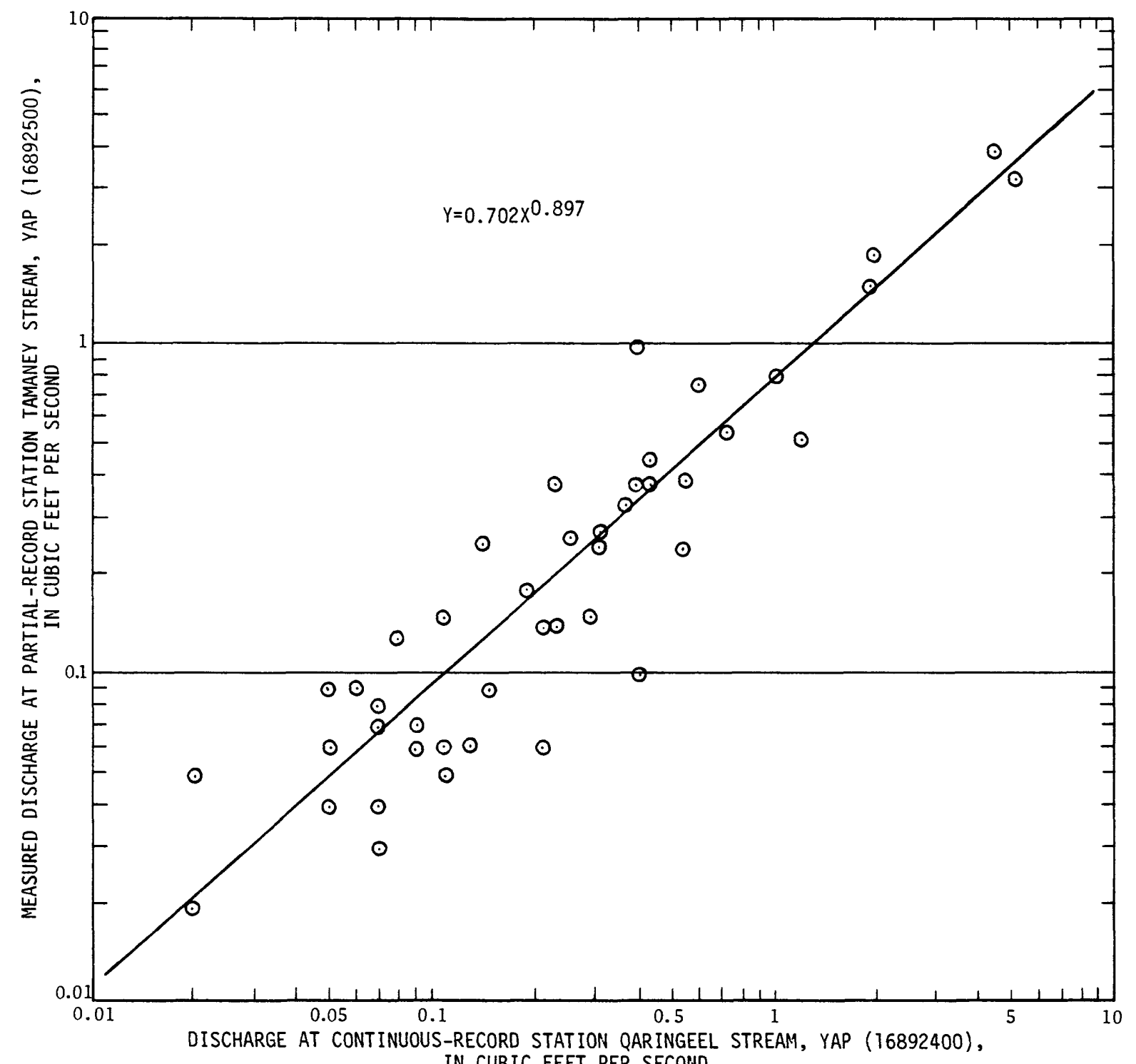

IN CUBIC FEET PER SECOND

Figure 15. Correlation between discharges at 1amaney and Qaringeel Streams. 


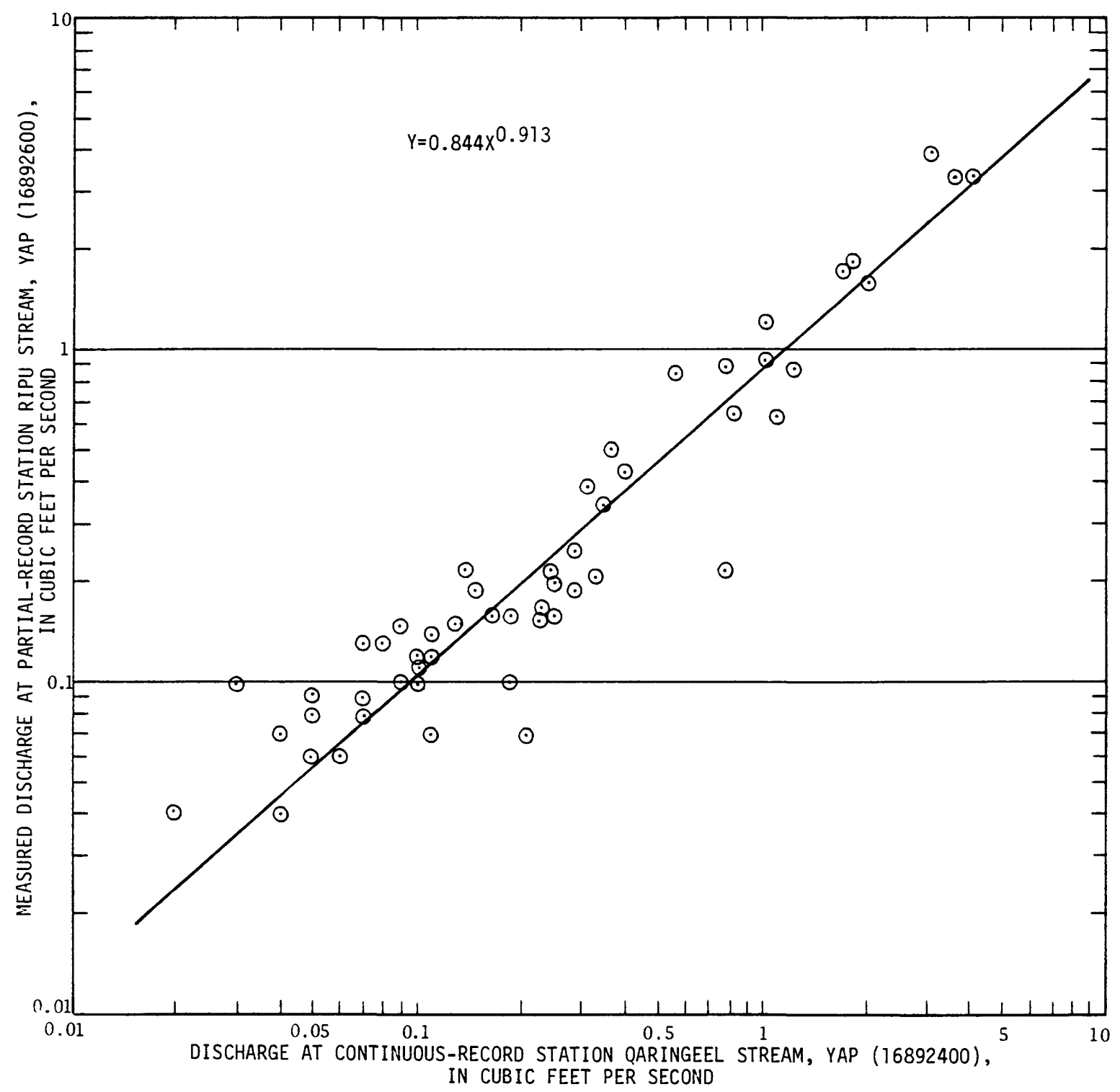

Figure 16. Correlation between discharges at Ripu and Qaringeel Streams. 


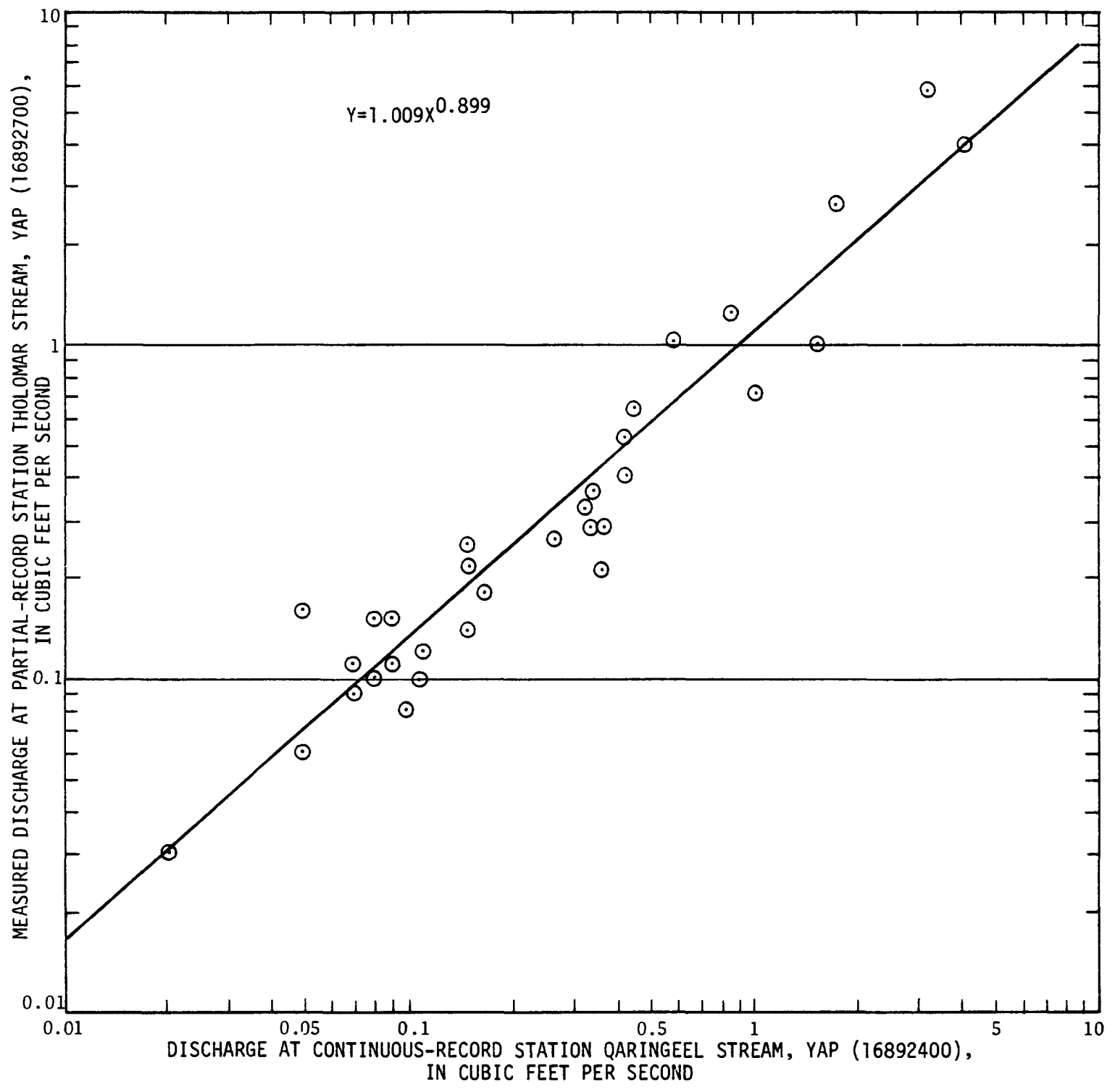

Figure 17. Correlation between discharges at Tholomar and Qaringeel Streams. 


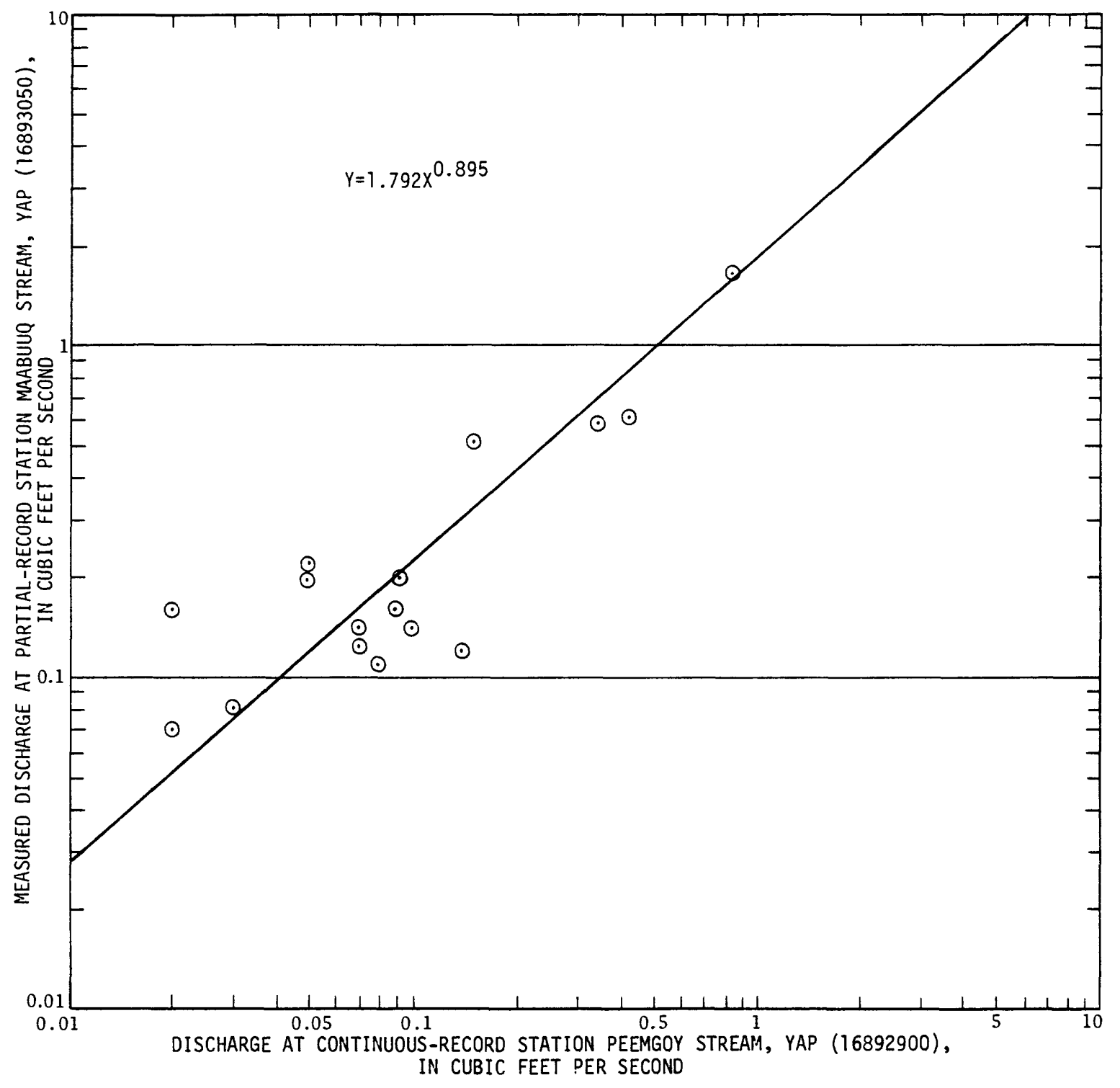

Figure 18. Correlation between discharges at Maabuuq and Peemgoy Streams. 


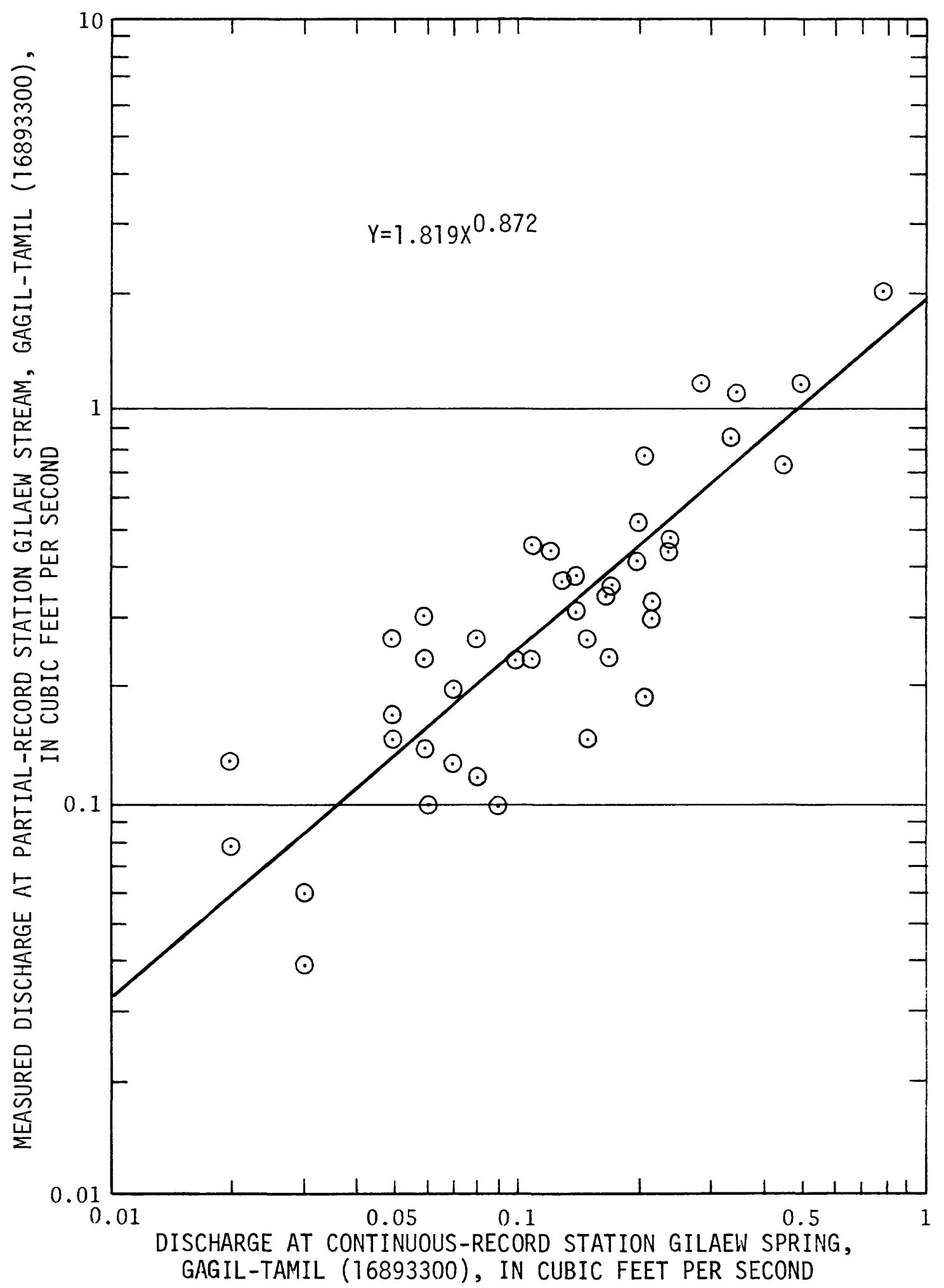

Figure 19. Correlation between discharges at Gilaew Stream and Gilaew Spring. 
Miller and Arnow (written communication, 1965) estimated that 20,000-25,000 gal/d (gallons per day) were pumped from the Gitaem Reservoir to a 42,000-gallon tank for use at the high school plus faculty homes and to three 12,000-gallon concrete tanks in Colonia built by the Japanese. Also 40,000 to 50,000 gal/d were distributed by gravity to Colonia. In 1959, a 450,000-gallon emergency storage reservoir was constructed at the Colonia dock area. This emergency reservoir also received rain runoff from the roof of the supply building. Water from this reservoir was used to supply ships and, via two booster pumps near the Spanish well, to the three 12,000-gallon tanks. Leakage of the old 4-inch distribution pipes was estimated by Austin, Smith and Associates, Inc. (1967) to be 40-45 percent of the total water production.

The supply of drinking water for Colonia of ten would be insufficient during the dry season. It then was necessary to haul water from a pond at the airfield and to severely limit consumption. This pond, which is called Airport Swamp or Luweech Swamp, averages about 500 feet in diameter and is estimated to be 10-15 feet deep. It has never been known to go dry (fig. 20).

A new dam at Gitaem was completed in 1975 and increased the water-storage capacity by $25 \mathrm{Mgal}$ (figs. 21 and 22 ).

Water production of the treatment plant at the lower dam is metered and a $\log$ is kept at the site (fig. 23). No production figures were available for periods when the meters were not working. For 1978, however, meter readings were almost complete and showed a mean monthly clear-water production of $9 \mathrm{Mgal}$ with a maximum monthly output of $11 \mathrm{Mgal}$ during September of that year.

In 1975, part of the old distribution system was replaced by 6-inch to 10inch asbestos distribution pipes. Two 1-Mgal storage tanks were then built at Nimaar and in Dalipeebinaew ( $\mathrm{fig} .24$ ).

By 1980 , almost all of the remaining 4-inch pipes were replaced, but the problem of leakage remained. This leakage is caused by poor connections between the old and new pipes, breaks in the new pipes where insufficient cushion material was used, and open or dripping water fixtures. 


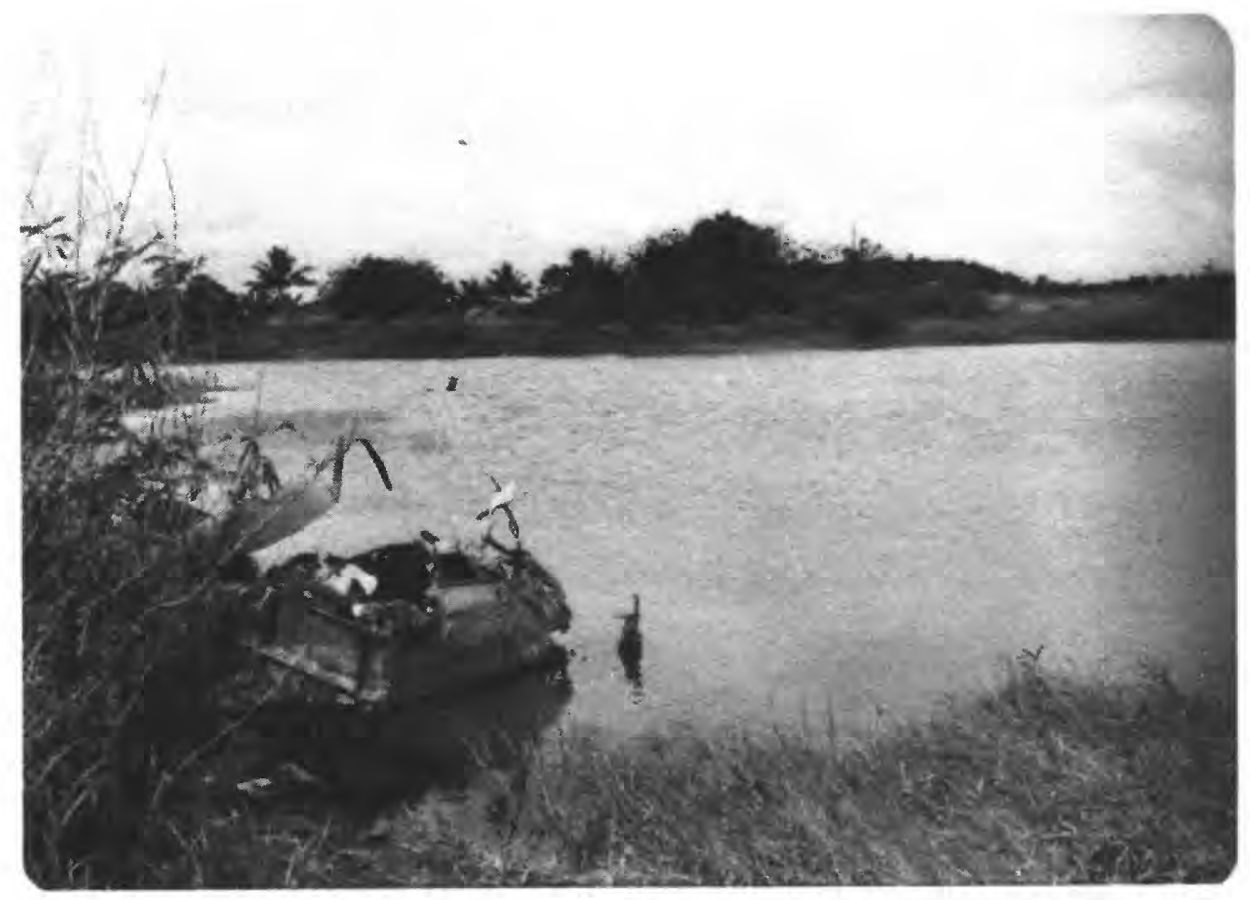

Figure 20. Airport swamp with wreck of Japanese fighter plane (view facing north). 


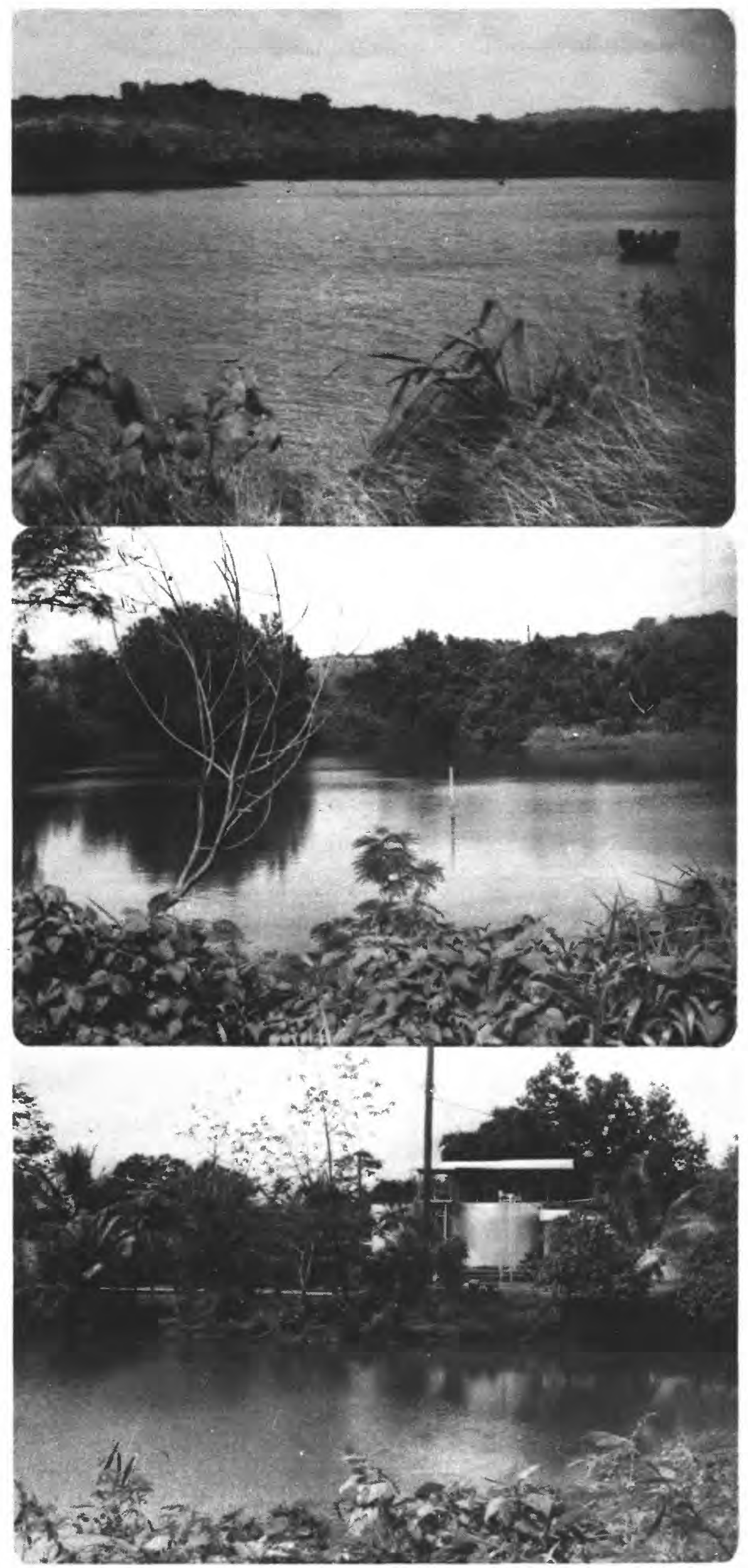

Figure 21.

25-Mgal (upper)

reservoir at Gitaem, Yap (view facing north).

Figure 22.

2-Mgal (lower) reservoir at Gitaem, Yap (view facing north).

Figure 23.

Treatment plant at Gitaem, Yap (view facing west). 


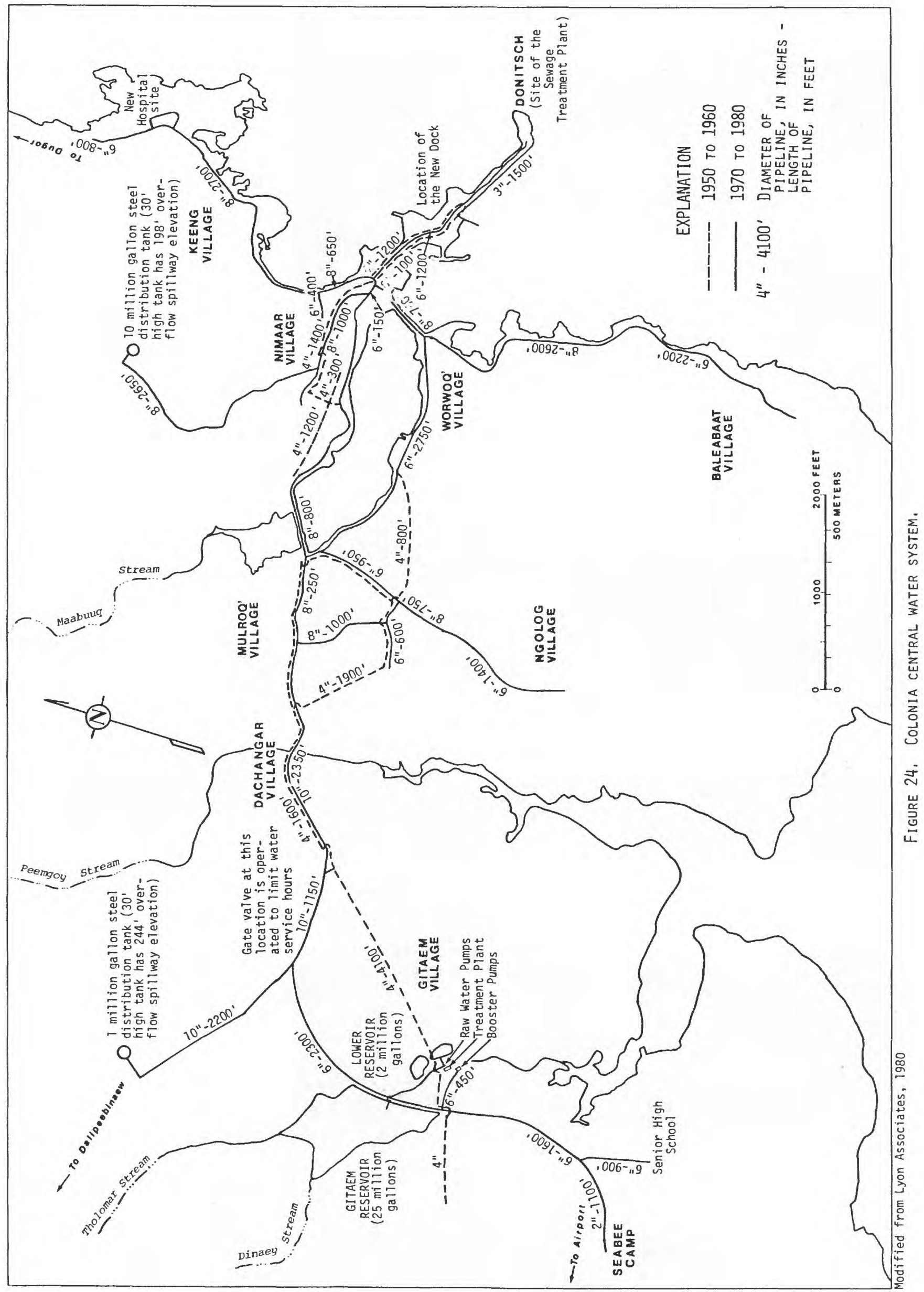


Lyon Associates (1980) calculated leakage to be $240 \mathrm{gal} / \mathrm{min}$. This necessitated closing the distribution system except for a few hours per day as the amount of leakage during a 24-hour period would be 345,000 gallons, exceeding the capacity of the treatment plant.

Young and others (1977) took six grab samples from the distribution system (date and location of samples unspecified, table 9) which showed that although the total coliform count in the upper Gitaem Reservoir was 5,800 per $100 \mathrm{~mL}$ (milliliters) and 95 per $100 \mathrm{~mL}$ in the lower reservoir, the levels in the distribution system were very low.

On April 8, 1979, the tap water in Colonia had a pH of 9.1 and a specific conductance of 170 umhos (micromhos) (USGS). The reason for this high pH reading is not known. From table 9 it appears the $\mathrm{pH}$ varies depending on where the sample was taken from the distribution system.

A chemical analysis of a water sample taken by the Geological Survey on September 20, 1980 of the finished water from the Gitaem treatment plant is shown in table 57 in the Hydrologic Data section. The $\mathrm{pH}$ reading for this sample appears to be normal.

\section{Ground Water}

Historical developments

Historically, villages depended upon rain catchments, shallow dug wells, and springs for water. The only known ground-water development was a well dug by the Spanish in a coastal flat of Colonia. After the construction of the dam on Dalibaech Stream in 1951, the well was used only occasionally until abandoned because of a slow recovery rate. During the Japanese Administration, concrete cisterns were built and wells dug in some villages, but most of these have fallen into disrepair.

In the early days of the American Administration (1947), a 10-foot deep, 10foot diameter well was dug about 300 feet west of the Spanish well in Colonia (see figure 28). At the time, the Spanish and the American wells were connected by a pipeline, and water was pumped from the American well to the Spanish well and from there to service tanks. It is not known whether the American well was used for any length of time. 
Table 9. Results of chemical and microbiological analyses on six grab sampler from the Colonic water-distribution system

[Total dissolved solids estimated on the basis of 65 percent of conductivity, as indicated in U.S. Geological Survey

Water Supply Paper 1454. All determinations were made in the field (Young and others, 1977)]

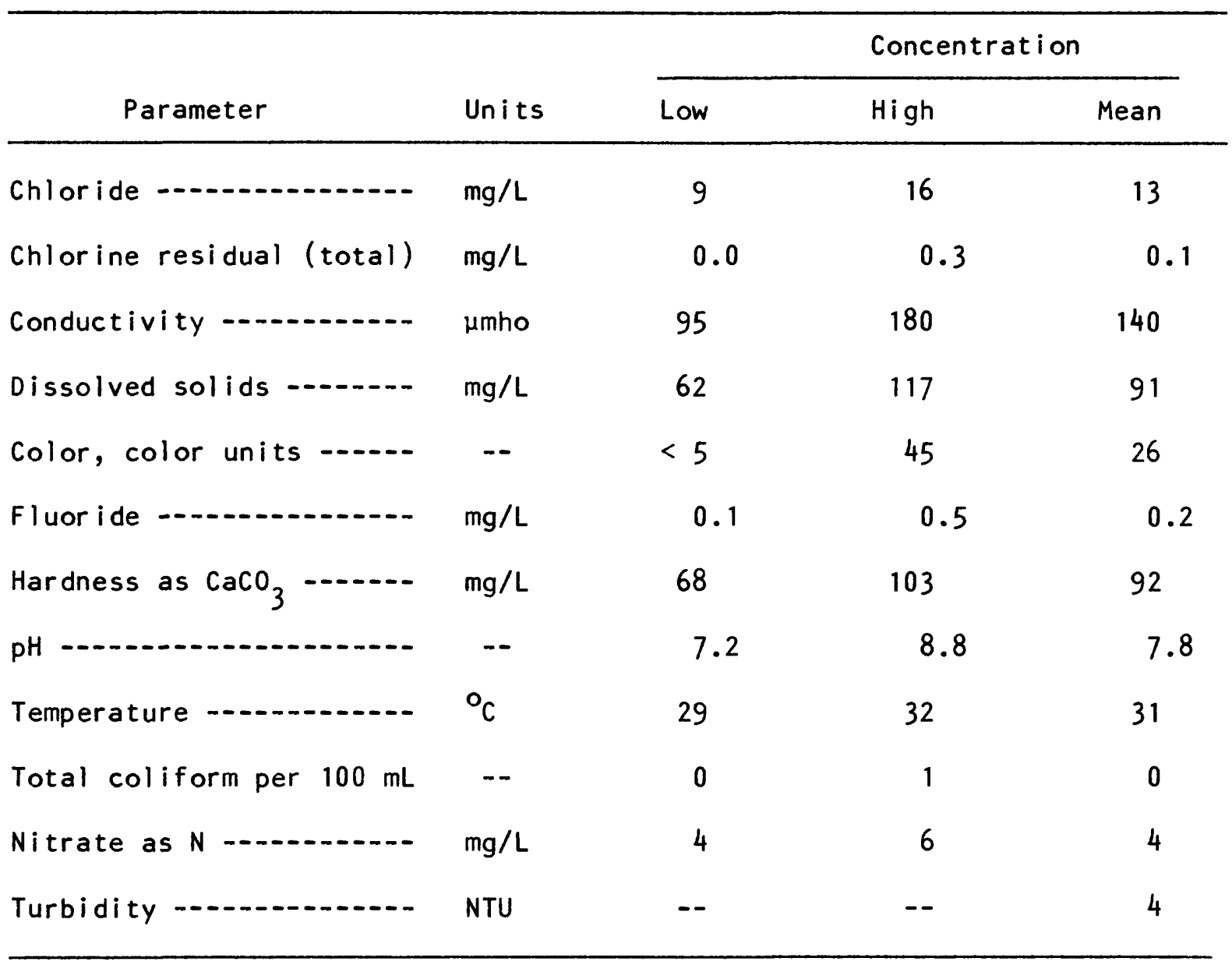

50 
Nature and occurrence

In "Military Geology of the Yap Islands," the authors concluded that because of dense bedrock with clayfilled fractures, the rock would have low permeability and contain little water. This was concluded on the basis of surface reconnaissance, as no drilling equipment was available.

Sunn, Low, Tom, and Hara, Inc. (1971) recognized the availability of ground water in central Tamil and, to a certain extent, in southern Yap on the basis of tests made on existing shallow wells and hand augering. Two wells were located on Tamil, one about 1,600 feet south of the LORAN station, the other about 2,300 feet north of Tamilang School at altitudes of 50 and 40 feet above mean sea level, respectively (fig. 25). At both sites the water surface was 3 inches below ground level but was quickly drawn down when bailed or pumped. The authors concluded that development of ground water in the central valley of Tamil might not be feasible as the ground water is perched at the shallow depth on stiff clayey silt and the aquifers have low permeability with a very limited storage capacity.

An existing spring at an altitude of 40 feet in Daabach on the west coast of Tamil, with a flow rate of $3.7 \mathrm{gal} / \mathrm{min}$ (measuring date not given), could supply water to the local inhabitants but this was not thought feasible for development as dwellings are widely scattered (fig. 25). However, Nance (1979) reports that the spring supplied water through a 2 -inch polyethylene pipe to Rumuug village on Yap Island.

At Gagil municipality, two shallow borings were drilled on east Gagil near the coast, but because of contamination of the ground water by decayed organic matter, no pumping tests were made and the area was considered unsuitable for water supply.

In Kanifaay, in southern Yap, two shallow wells were found. The first, about 650 feet west of the existing church and school in a narrow ravine at about a 15-foot altitude (fig. 25), has a diameter of 4 feet and is partly lined with steel casing with the water table standing several inches below the collar. Local residents reported that the well water was used for drinking. Information on the yield was not available. 


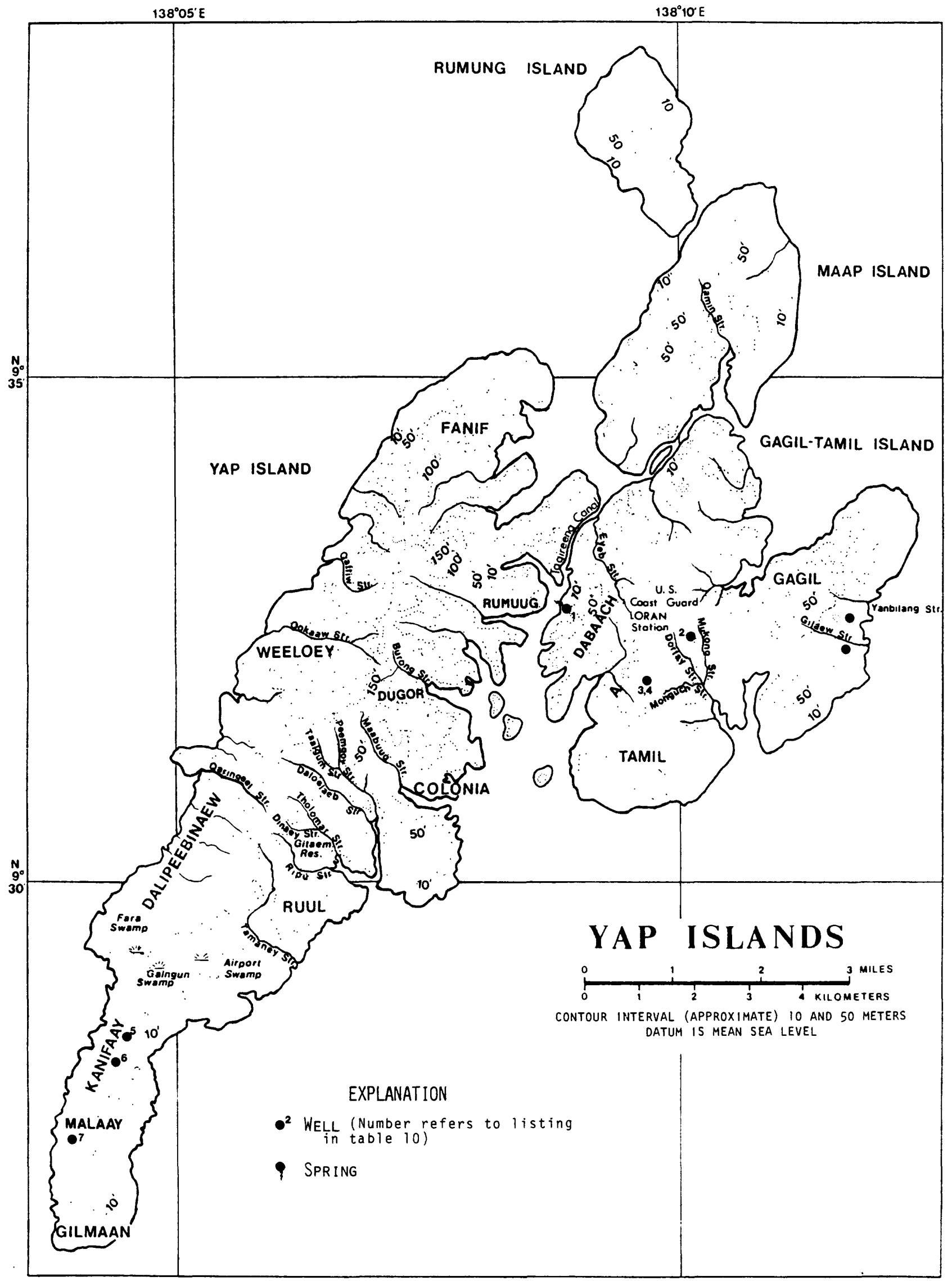

Figure 25. Location of wells and spring on Gagil-Tamil and SOUTHERN Yap, 1971. 
The second well is located southwest of the first, at an altitude of approximately 5 feet. It is about 4 feet square and lined with schist boulders. The water table was standing at about 1.4 feet below ground surface. According to local residents the well was abandoned because of salinity and poor supply during the dry season.

Three 6-inch-diameter, 9-foot-deep holes were drilled for pumping and observation about 250 feet east of the central-road and Malaay village-road intersection. Water was encountered at a depth of 3.2 feet but dropped 1.6 feet after 4 hours when pumped at a rate of $6 \mathrm{gal} / \mathrm{min}$, remaining at that level for an additional 2 hours of pumping.

From their investigation the authors (Sunn, Low, Tom, and Hara, 1971) concluded that shallow ground-water sources in southern Yap could be developed satisfactorily throughout most of Kanifaay municipality, using infiltration galleries in the wider coastal flats and shallow dug wells above narrow flats. Measurements of chloride and dissolved solids at seven sites are listed in table 10 .

Table 10. Partial chemical analyses of water samples taken January 1971

[Source: Sunn, Low, Tom and Hara, 1971]

\begin{tabular}{llcc}
\hline $\begin{array}{c}\text { Site } \\
\text { Number }\end{array}$ & Location & $\begin{array}{c}\text { Chloride } \\
(\mathrm{mg} / \mathrm{L})\end{array}$ & $\begin{array}{c}\text { Total } \\
\text { dissolved } \\
\text { solids } \\
\text { (mg/L) }\end{array}$ \\
\hline 1 & Daabach (Deboch Village) Spring, Tamil & 10.5 & 136 \\
2 & Test well near LORAN station, Tamil & 10 & 58 \\
3 & Test well near Tamil School & 15 & 20 \\
4 & Test well near Tamil School & 10.5 & 88 \\
5 & Existing well in Kanifaay & 13.5 & 276 \\
6 & Existing well in Kanifaay & 7 & 360 \\
7 & Test well in Malaay (Malai), Kanifaay & 7 & 178 \\
\hline
\end{tabular}


In 1977, while testing drilling equipment for subsurface investigations for a proposed new airport, Lyon Associates Inc. (Nance, 1979) drilled a test hole behind the Communication Station near the existing airport. The bit penetrated 30 feet of clayey soil followed by 70 feet of sandy silt. The hole was cased with 2-inch galvanized pipe, and since then the well has been producing water for the Communication Station at a rate of about 300-500 gal/d. (For chemical analyses of the water by USGS, see table 60.)

In 1979, 15 exploratory wells were drilled by Lyon Associates (fig. 26). One hole was drilled in serpentine rock next to Gagil School. Below 13 feet of sand and silt, decomposed serpentine was encountered grading into highly fractured rock 7 feet farther down. No water was found. Four wells were drilled in Tamil and, below a surface layer of 5-14 feet of clayey soil, sandy silt was found to a depth ranging from 33 feet to about 100 feet where basement rock of schist was encountered. Similar conditions were encountered at three drilling sites near the Yap Airport. The basement rock was almost impermeable and formed a bottom to the sand and silt which contained some water. Because of the areal extent of this layer of sand and silt, this aquifer should be able to yield a limited amount of water (Nance, 1979).

In southern Yap, where three wells also were drilled, no permeable material was encountered, as the clayey silt was found to be resting directly on the basement rock. This rock, decomposed schist at the top and fractured schist below, was considered impermeable as the fractures appeared to be filled with clay (Nance, 1979). This differs from the findings of Sunn, Low, Tom, and Hara (1971) who concluded that shallow wells in or near the coastal flats could be developed satisfactorily.

On the west coast of Yap Island four wells were drilled, three in schist and one in the alluvial material of the Qokaaw River valley. Permeability of the rock formation was poor and ground-water yield questionable, at best. The lokaaw well proved to be located in an old mangrove swamp. 


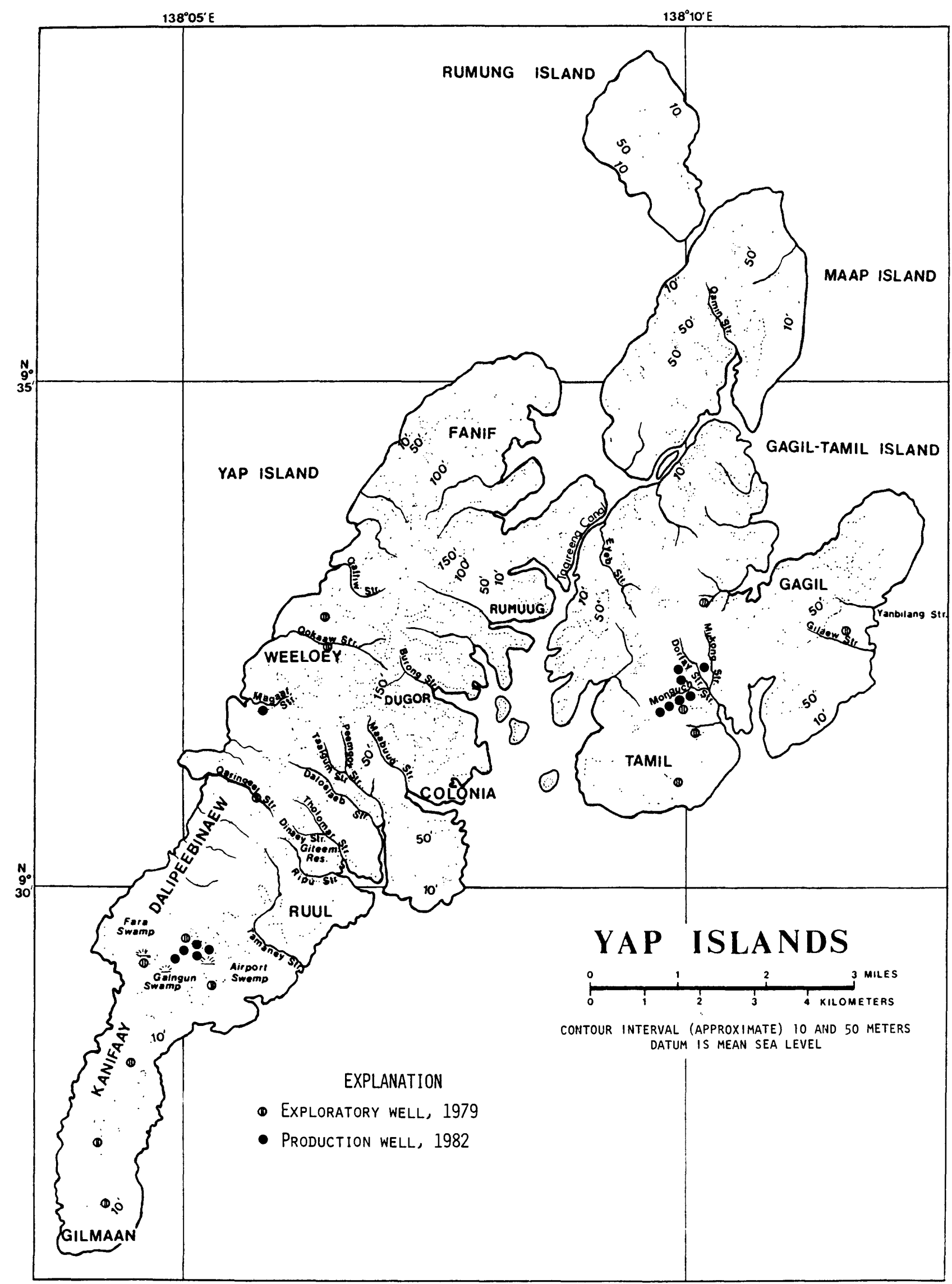

Figure 26. LOCATION OF WELLS DRILLED IN 1979 AND 1982. 
Lyon Associates (1980) concluded that the large aquifers in central Tamil and the airport area would be well suited for ground-water development. Although the permeability of the deeper sandy silt is not high, the central Tamil aquifer could provide water for most of the people on Gagil-Tamil, and the airport aquifer could supply all of southern Yap. Water use in the villages is estimated to be as low as 20-40 gallons per person per day. Drilling logs, pumping tests, and a listing of the springs, seeps, and dug wells of the Yap Islands can be found in "Yap Islands, Groundwater Exploration April to August 1979" by Tom Nance for Lyon Associates, Inc.

Following the recommendations of Nance, 13 wells were drilled in the first few months of 1982--7 in the central valley of Tamil, 5 near the Yap airport, and 1 at Magaaf Stream, Yap (fig. 26). On Tamil, the depths of the 4 southernmost wells varied from 71 to 87 feet below mean sea level and the depths of the other 3 wells varied from 93 to 145 feet. The water-bearing formation of the Mukong Stream well was white coral rock and that of the other 6 wells, medium-hard brown rock. The combined aquifer yield is expected to exceed $200 \mathrm{gal} / \mathrm{min}$ (Nance, 1982). A 24-hour pumping test of three of the southernmost well s caused drawdown at all wells except the Mukong Stream well. This indicates that the Mukong Stream well draws from a separate aquifer. Water from the wells will be pumped to a 100,000-gallon tank for distribution to nearby villages.

Five wells were drilled northwest of the Airport Swamp on Yap Island. All were drilled until hard schist rock was encountered at a depth of 25 to 50 feet below mean sea level. The water-bearing rock, just above the hard schist, consisted of softer greenish-gray and gray rock. A combined yield of $100 \mathrm{gal} / \mathrm{min}$ is expected (Nance, 1982). The water will be used to supply villages in the southern part of the island.

Chemical analyses of water from each aquifer, the two on Tamil and the one near the airport, are given in table 61 and show the water to be of good quality.

The well drilled at Magaaf Stream was located 4 feet from the test hole drilled in 1979. At this well, the water comes from schist rock in the middle depth and the bottom of the well. The yield of the well during the dry season is expected to be at least $10 \mathrm{gal} / \mathrm{min}$.

Drilling logs of the 13 wells and of four test holes and results of pumping tests can be found in "Yap I sland Water Well Development, January to March 1982," by Tom Nance (1982) for Lyon Associates, Inc. Readings of the depth to water of 12 of the wells are given in table 11. 
Table 11. Depth to water, in feet, of wells on Yap and Gagil-Tamil

[Measuring point is top of casing]

\begin{tabular}{|c|c|c|c|c|}
\hline \multirow[t]{2}{*}{ Well } & $\begin{array}{l}\text { Altitude } \\
\text { top of } \\
\text { casing } \\
(f t)\end{array}$ & \multicolumn{3}{|r|}{ Depth to water } \\
\hline & & \multicolumn{3}{|c|}{ Nance, 1982} \\
\hline \multirow[t]{2}{*}{ Yap Island } & & & 1982 & \\
\hline & & $\begin{array}{l}\text { Feb. } \\
19\end{array}$ & $\begin{array}{c}\text { Mar. } \\
2 \\
\end{array}$ & $\begin{array}{c}\text { Mar. } \\
9 \\
\end{array}$ \\
\hline $\begin{array}{l}\text { Yugamanman } 1 \\
\text { Yugamanman } 2 \\
\text { Timlang } 1 \\
\text { Timlang } 2 \\
\text { Timlang } 3\end{array}$ & $\begin{array}{l}42.68 \\
38.83 \\
42.68 \\
40.43 \\
44.22\end{array}$ & $\begin{array}{r}-- \\
9.01 \\
9.10 \\
12.33\end{array}$ & $\begin{array}{c}-- \\
-- \\
10.43 \\
10.32 \\
13.44\end{array}$ & $\begin{array}{l}15.52 \\
12.83 \\
11.30 \\
11.79 \\
13.02\end{array}$ \\
\hline
\end{tabular}

U.S. Geological Survey

Yap I sland

Magaf

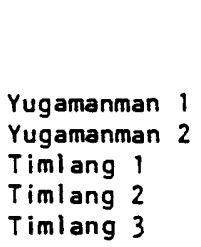

Gagi l-Tami I

Monguch 1

Monguch 2

Monguch 3

Monguch 4

Mukong

Dorfay 4"

Dorfay 6"1

-.

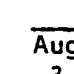

Sept. Sept. Sept.

$\frac{3}{8.94} \frac{1}{8.95} \frac{16}{--}$

Sept.
30

July

29

42.68

38.83

42.68

40.43

44.22

13.30

11.15
8.19

8.35

10.30

10.30

4.54

6.43

June

26

21.38

26.47

$-$

-

29.93

30.92

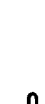

\section{0}

1.75

1.58

5.39

9.64

7.23

11.22

$$
0
$$

2.97

1.74

5.63

9.78

7.81

11.49
--

13.05

10.80

7.43

8.02

Sept.

29

0

1.84

1.70
5.57

-

8.00
11.37
.17

.17
2.32

2.35

6.43

10.19

9.13

11.67

\subsection{3}

12.06

8.61

9.51

-.

16.38

13.40

11.05

12.86

--

$\begin{array}{rr} & \\ .40 & .64 \\ 2.66 & 2.97 \\ 2.77 & 3.13 \\ 6.89 & 7.41 \\ 10.38 & 10.57 \\ 9.56 & 9.65 \\ 11.86 & 11.93\end{array}$

Note: Yugamanman wells also called Faraq-Lamaer wells and Timlang wells also called Weather Bureau wells. 1/ From Nance, 1982.
15.60
12.85
9.80
11.58

19.69

16.19

14.82

17.26

23.38
19.60

19.60
20.60

1983

Feb. Mar.

-. $=$

Feb.

Feb.

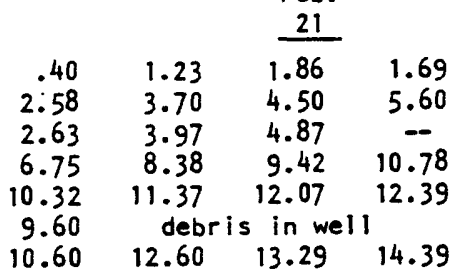




\section{Water Quality}

$\underline{\text { General }}$

Rainfall is the source of all surface water of the Yap Islands. The quality of the surface water is good as the concentration of all chemicals analyzed are well within the maximum permissible level recommended for domestic use by the World Health Organization (1971).

A number of stream-water samples were collected from pools at gaging stations where the streams were either not flowing or almost dry when visited. These samples may not be representative of regular streamflow and results are not included in the following assessment of the surface water.

The dissolved solids concentration of surface water on the Island of Yap ranged from 48 to $104 \mathrm{mg} / \mathrm{L}$ (milligrams per liter) and on Gagil-Tamil from 23-83 $\mathrm{mg} / \mathrm{L}$. Silica concentrations ranging from 9.5 to $23 \mathrm{mg} / \mathrm{L}$ and const ituting from 20 to 35 percent of the dissolved solids on Yap and concentrations of 4.4 to $18 \mathrm{mg} / \mathrm{L}$ constituting from 16 to 36 percent of the dissolved solids on Gagil-Tamil, are characteristic of rain water flowing over tropical volcanic terrain. 0ther constituents in decreasing order of concentration were chloride, magnesium, calcium, sodium, sulfate, potassium, nitrite plus nitrate nitrogen, and fluoride.

The iron concentration of surface water on Yap Island ranged from 81-450 $\mu \mathrm{g} / \mathrm{L}$ (micrograms per liter) with a mean of $237 \mu \mathrm{g} / \mathrm{L}$ (25 analyses). Iron concentrations for streams on Gagil-Tamil were as high as 1,000 $\mathrm{gg} / \mathrm{L}$ and averaged 332 $\mu \mathrm{g} / \mathrm{L}$ ( 15 analyses). Iron is a minor element in water but can cause considerable problems when the concentration exceeds $300 \mu \mathrm{g} / \mathrm{L}$. It can cause problems with taste, discoloration, turbidity, and growth of iron bacteria. The World Health Organization (1971) recommended a desirable level of $100 \mu \mathrm{g} / \mathrm{L}$ and a maximum permissible level of $1,000 \mu \mathrm{g} / \mathrm{L}$.

Runoff from tropical storms is usually flashy and can cause turbidity problems in stream water and coastal waters. However, storm duration is generally short and streams revert to base flow with clear water within a short time. Physical quality data, in terms of specific conductance, pH, temperature and turbidity, are included in the chemical analyses as an integral part of the baseline information. 
Specific conductance is expressed in micromhos per centimeter at $25^{\circ} \mathrm{C}$. It is a measure of the ability of water to transmit an electric current and is used as an indicator of the concentration of dissolved solids in water; the more dissolved solids, the greater the conductance. The specific conductance of stream water on the Yap I slands did not exceed 138 umhos.

A measure of acidity or basicity is $\mathrm{pH}$. In natural water, the level of $\mathrm{pH}$ depends on chemical and biological processes. For streams on Yap Island, pH values ranged from 7.1 to 7.4 and for Gagil-Tamil from 6.1 to 7.3. The levels are within the recommended range for public water supply (World Health Organization, 1971).

\section{Chemical analyses}

Before 1979 there were no systematic chemical analyses made of water from sources in the Yap Islands. In 1928, Hajime Arai took 144 samples from water sources in the Japanese administered islands; a number of these samples were from Yap (Naval Medical Association Bulletin). The analytical results are not listed here because a copy of this publication could not be obtained.

In response to a request by the High Commissioner of the Trust Territory of the Pacific Islands, Ted Arnow of the U.S. Geological Survey reported on the water-supply conditions on Yap (written communication, Nov. 12, 1952). On September 30, 1952, he collected a water sample from the Spanish well in Colonia for chemical analyses (fig. 27). The water had a pH of 7.2 , a specific conductance of 513 umhos and the dissolved constituents listed in table 12.

Water samples for bacteriological and chemical analyses were collected at seven locations in the Yap Islands by Austin, Smith, and Associates (1967) in August 1967 and the results of the chemical analyses are listed in table 13. Bacteriological analysis revealed 600 coliform colonies in a $10-\mathrm{mL}$ sample taken from the Airport Swamp, while untreated water at the Gitaem Reservoir and water from Chamorro Bay and at several locations along the coast near Colonia had in excess of 24,000 coliform colonies per $10 \mathrm{~mL}$.

A water sample taken by the U.S. Geological Survey on August 11, 1978 from the well at the Communication Station showed $20 \mathrm{mg} / \mathrm{L}$ chloride and on April 8 , 1979, the $\mathrm{pH}$ and specific conductance of water from the Airport Swamp were 8.5 and 160 umhos (USGS). In August 1979, water samples were taken for Lyon Associates (Nance, 1979) from the Faraq test well on Yap and from Monguch Stream on Gagil-Tamil. The analytical results are listed in table 14. 


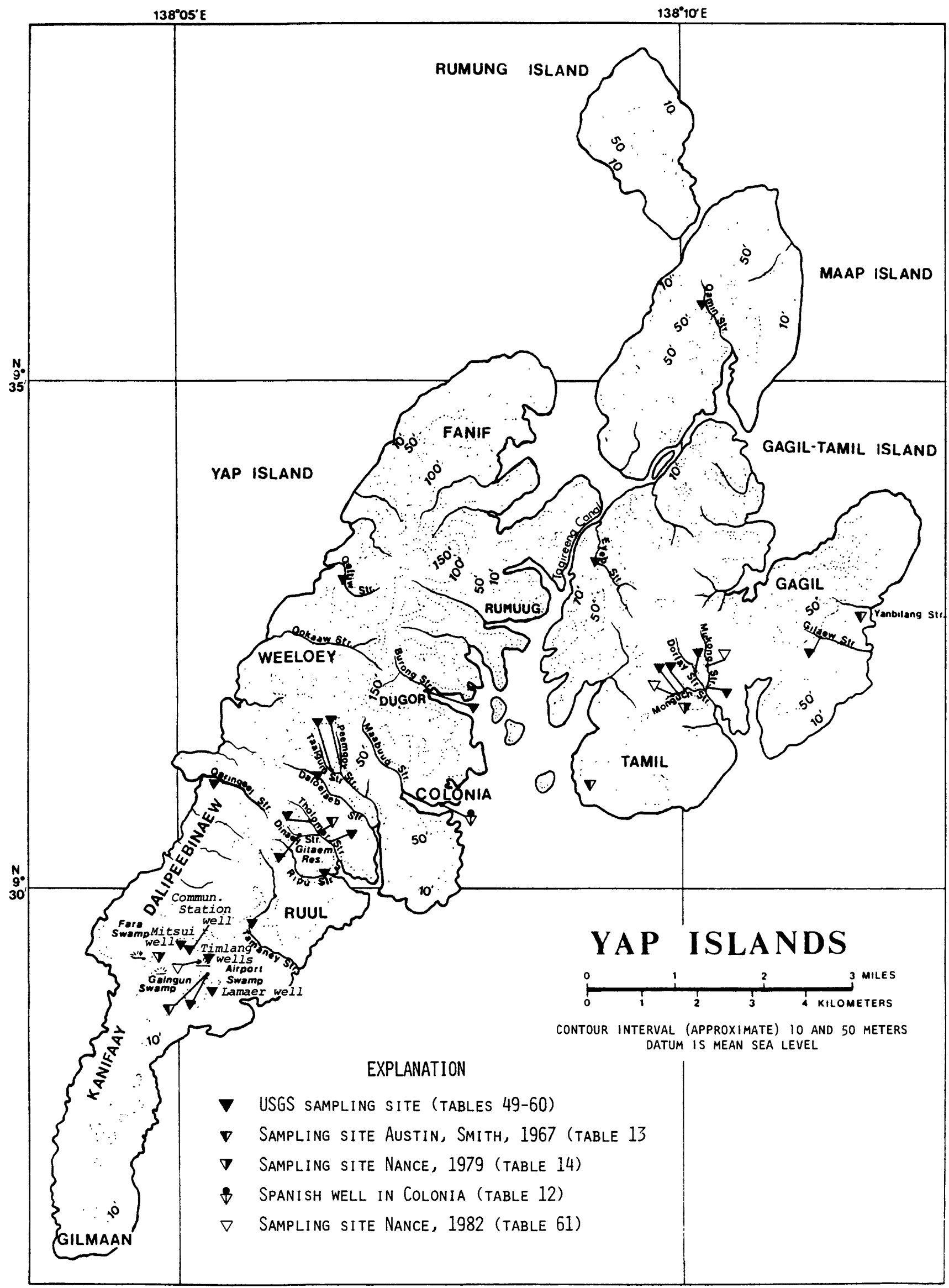

Figure 27. LOCATION OF SITES WHERE CHEMICAL ANALYSES OF WATER WERE MADE. 
Table 12. Chemical analysis of water from the Spanish well (1952)

[Collected: September 30, 1952. Analyzed by U.S. Geological Survey, Salt Lake City Laboratory]

\begin{tabular}{|c|c|}
\hline $\begin{array}{l}\text { Dissolved } \\
\text { const ituent }\end{array}$ & $\mathrm{Mg} / \mathrm{L}-\underline{\prime}$ \\
\hline Silica $\left(\mathrm{SiO}_{2}\right)$ & 37 \\
\hline I ron $(\mathrm{Fe})$ - & .04 \\
\hline Calcium (Ca) - & 28 \\
\hline Magnesi um（Mg）-1 - & 43 \\
\hline Sodium $(\mathrm{Na})$ & 21 \\
\hline Potass i um (K) & .5 \\
\hline Bicarbonate $\left(\mathrm{HCO}_{3}\right)$ & 316 \\
\hline Sulphate $\left(\mathrm{SO}_{4}\right)$ & 7.6 \\
\hline Chloride (Cl) & 15 \\
\hline Fluoride (F) - & 0 \\
\hline Nitrate $\left(\mathrm{NO}_{3}\right)$ & 1.9 \\
\hline Hardness - & 247 \\
\hline Dissolved solids (Residue at $180^{\circ} \mathrm{C}$ ) & 285 \\
\hline
\end{tabular}

1/ Originally reported in parts per million by Miller and Arnow (written communication, 1965). Parts per million is numerically equivalent to milligrams per liter. 
Table 13. Chemical analyses reported by Austin, Smith and Associates (1967) [Collected: August 1967. Units reported in parts per million]

\begin{tabular}{|c|c|c|c|c|c|c|c|}
\hline & $\begin{array}{c}\text { A i rport } \\
\text { Swamp, } \\
\text { Yap }\end{array}$ & $\begin{array}{l}\text { Colonia } \\
\underline{1} \text { (un- } \\
\text { treated) }\end{array}$ & $\begin{array}{c}\text { Colonia } \\
\underline{2}(\text { treated })\end{array}$ & $\begin{array}{c}\text { Stream } \\
\text { on } \\
\text { Tamil }\end{array}$ & $\begin{array}{c}\text { Stream } \\
\text { on } \\
\text { Gagil }\end{array}$ & $\begin{array}{l}\text { Seep } \\
\text { on } \\
\text { Maap }\end{array}$ & $\begin{array}{c}\text { Seep } \\
\text { on } \\
\text { Rumung }\end{array}$ \\
\hline pH - - - - - & 8.0 & 7.6 & 8.5 & 8.1 & 8.2 & 6.8 & 8.0 \\
\hline Turbidity -- & 0 & 50 & 20 & 0 & 0 & 15 & 10 \\
\hline Alkalinity - & 15 & 30 & 10 & 30 & 95 & 155 & 105 \\
\hline $\mathrm{CaCO}_{3} \ldots$ & 10 & 25 & 50 & 10 & 80 & 140 & 85 \\
\hline Chloride -.- & 8 & 12 & 16 & 10 & 15 & 25 & 25 \\
\hline Iron & .1 & .3 & .2 & .15 & .05 & .8 & .35 \\
\hline Copper - - - & .05 & .05 & .05 & .05 & .15 & .1 & .25 \\
\hline Manganese -- & .5 & .3 & .3 & .4 & 1.2 & 1.8 & 2.1 \\
\hline Sulphate -- & 7 & 13 & 12 & 9 & 11 & 17 & 12 \\
\hline Nitrate $\ldots$ & - & 4.4 & 8.0 & 35 & 18 & 14 & 25 \\
\hline Silica & 8 & -- & 14 & 20 & 40 & 75 & 53 \\
\hline Phosphate -- & 3.7 & -- & .2 & .2 & .1 & .6 & .1 \\
\hline
\end{tabular}

1/ Untreated source of Colonia water-supply system is Tholomar Stream, Yap.

2/ Treatment not specified. 
Table 14. Chemical analyses made for Lyon Associates (1979)

[Source: Nance, 1979. Samples analyzed by Brewer Analytical

Laboratories, Honolulu, August 31 to September 14, 1979.

Units reported in milligrams per liter]

\begin{tabular}{|c|c|c|}
\hline Chemical constituent & $\begin{array}{c}\text { Faraq test } \\
\text { well, Yap } \\
\text { Aug. 18, } 1979\end{array}$ & $\begin{array}{c}\text { Monguch Stream, } \\
\text { Gagi I-Tamil } \\
\text { Aug. 19, } 1979\end{array}$ \\
\hline Fluoride & 0.02 & 0.01 \\
\hline Nitrate nitrogen & .14 & .05 \\
\hline Cyan ide -1. & $<.01$ & $<.01$ \\
\hline Sulfate $-1,-10$ & 3 & 4 \\
\hline Total dissolved solids & 156 & 55 \\
\hline Arsenic & $<.05$ & $<.05$ \\
\hline Selen ium -1 & $<.010$ & $<.010$ \\
\hline Barium & $<1$ & $<1$ \\
\hline Cadmi um & $<.010$ & $<.010$ \\
\hline Chromi um & $<.05$ & $<.05$ \\
\hline 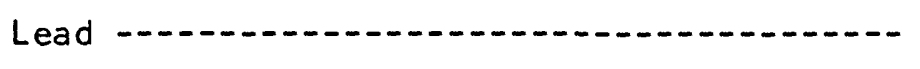 & .02 & .02 \\
\hline Silver & $<.001$ & $<.001$ \\
\hline Copper & .01 & .01 \\
\hline 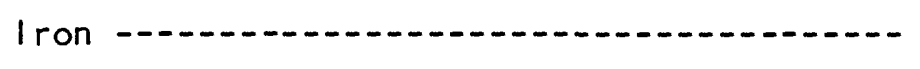 & .16 & .04 \\
\hline Manganese & .34 & .35 \\
\hline Zinc & 1.08 & .01 \\
\hline Mercury & $<.00005$ & $<.00005$ \\
\hline
\end{tabular}


In 1979, the U.S. Geological Survey began a program to collect and analyze water samples from all major water sources in the Yap Islands. Results of chemical analyses made of water from 10 streams on the Island of Yap are remarkably similar. The chemical analyses of water from one spring and four streams on Gagil-Tamil show more variation. Water from Monguch Stream proved to be very low in dissolved solids but high in iron concentration. The concentrations of constituents of ground water in Yap and Gagil-Tamil Island are similar to those of the surface water except for a noticeably greater concentration of silica and less dissolved iron in ground water. Tables 49-60 in the Hydrologic Data section list the data obtained thus far at the following locations:

Table

Gaging stations sites:

Qatliw (Atelu) Stream, Yap 49

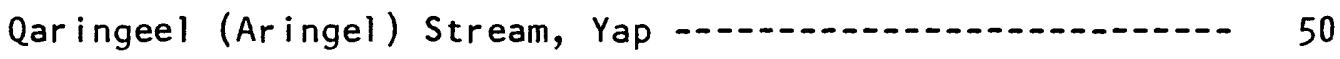

Daloelaeb (Dalolab) Stream, Yap -....... 51

Peemgoy (Pemgoy) Stream, Yap

Taalgum (Talagu) Stream, Yap _... 53

Burong Stream, Yap -

Mukong Stream, Gagil-Tamil 55

Eyeb Stream, Gagil-Tamil 56

Low-flow partial-record sites:

Tamaney Stream, Yap 57

Ripu Stream, Yap - 57

Dinaey (Dinay) Stream, Yap 57

Tholomar (Thalomar) Stream, Yap - 57

Monguch Stream, Gagil-Tamil - 58

Gilaew (Bileiy) Spring, Gagil-Tamil - 58

Qamin (Amin) Stream, Maap _... 58 
Miscellaneous sites:

Dorfay Stream, Gagil-Tamil - 58

Airport Swamp, Yap -_. 59

Water treatment plant, Yap - 59

Timlang 3 well, Yap - 60

Lamaer well, Yap

Communication Station well, Yap - 60

Mitsui well, Yap -_. 60

Monguch 1 well, Gagil-Tamil 60

\section{Water temperatures}

Stream temperatures do not vary much on the Yap Islands. They fluctuate somewhat with ambient conditions and are normally highest in midafternoon. Temperature is an important consideration because of its effect on chemical reactions and biological activities.

Water temperatures are normally obtained when a discharge measurement of streamflow is made. These temperatures are listed in tables 62-81 in the Hydrologic Data section. 


\section{APPLICATION OF DATA FOR FUTURE WATER DEVELOPMENT}

\section{Reservoirs}

Population growth and higher per-capita water consumption will increase the demand for potable water in Colonia. Population is expected to be nearly 2,000 in 1987 (Hawai i Architects and Engineers, Inc., 1968). Not included in this estimate are those government employees who work and live in Colonia during the week and live elsewhere on the weekends. Lyon Associates (1980) calculated the water demand in 1980 as $118,000 \mathrm{gal} / \mathrm{d}$ and estimated a demand of $192,000 \mathrm{gal} / \mathrm{d}$ in 1990 and $258,000 \mathrm{gal} / \mathrm{d}$ in 2000, using the 3.3 percent annual growth rate of the Quarterly Bulletin of Statistics (Trust Territory of the Pacific Islands, 1979).

A demand to extend the water-distribution system outside Colonia and other areas that are presently served is anticipated. As saltwater conversion is too expensive and substantial ground-water development appears difficult, the most feasible way to increase the public water supply is by surface-water development. Miller and Arnow (written communication, 1965) evaluated some potential surfacewater sites as follows:

On the basis of the above estimated requirements, (in 1965, it was expected that there would be about 3,000 people in the area requiring water service) field investigations were made of several streams that could provide substantially larger supplies than are presently being used. The investigations were mainly in the headwater areas to secure a source of supply for gravity feed to places of use and to greatly reduce the chances for pollution that exist at lower reservoir sites. The sources investigated are described below, and possible dam sites are shown **: (fig. 28).

Mabu Stream.--Mabu Stream heads on the south side of Mt. Matade and drains into Chamorro Bay near Colonia. A dam site was found just below the confluence of two tributaries at about the 50-meter contour. A rough estimate indicates that a dam $30 \mathrm{feet}$ high and 100 to $150 \mathrm{feet}$ long would have a storage capacity of about 20 million gallons.

Pemgoy Stream.--Pemgoy Stream drains the basin immediately west of Mabu. Below its confluence with Talagu Stream at about 25 meters in elevation, it is known as Keyar Stream and flows southeast to Ngolog Bay at Dachngar. A dam site was found at about 35 meters in elevation approximately 500 feet above its confluence with Talagu Stream. A dam at this site approximately 25 feet high and 90 feet long would form a reservoir having a storage capacity of about $10 \mathrm{million}$ gallons. A 35-foot dam about 100 feet long would impound about $20 \mathrm{million}$ gallons. 


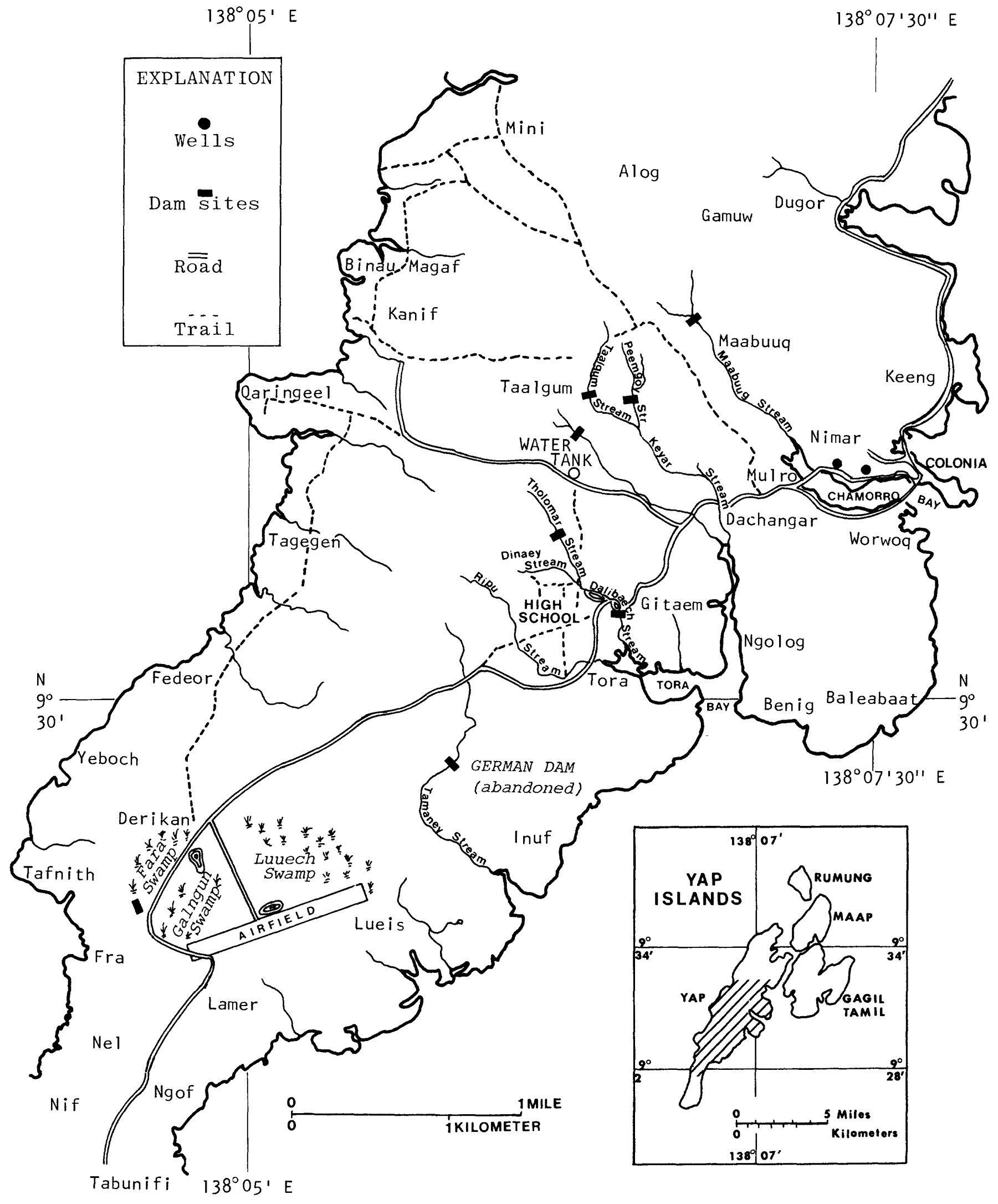

Figure 28. Map of south central Yap Island showing possible dam sites (written communication, Miller and Arnow, 1965). 
Talagu Stream.--Talagu Stream presented a good potential dam site at an elevation of about 50 meters. Storage behind a 25-foot dam, 80 feet long, would be about 10 million gallons.

Dalolab Stream.--Dalolab Stream drains the basin immediately southwest of the Talagu-Pemgoy basin and north of the cross-island road to Kanif. It also flows into Ngolog Bay at Dachngar. A 42,000-gallon temporary water-service storage tank is located on a hill between the road and Dalolab Stream at about 77 meters in elevation. A dam site was found at an elevation of about 45 meters roughly 1,000 feet north of the water-tank hill. Storage behind a 25-foot dam, 100 feet long, would be about 10 million gallons.

To illustrate possible yield from a small dam, mass curves of monthly mean discharges (1969-79) were drawn for Daloelaeb (Dalolab), Peemgoy (Pemgoy), and Taalgum (Talagu) Streams. Mass curves are used for storage analyses. Any desired draft rate can be represented by a straight line of appropriate slope drawn for the most critical period. The needed storage is indicated by the maximum vertical distance between the draft rate slope and the mass curve. Figures 29, 30 , and 31 show the maximum draft rate for three streams and the required storage. No evaporation losses were considered. These would amount to an average of about half a foot per month (see table 25 in the Hydrologic Data section).

Because the discharge of the three streams during 1969-79 did not fluctuate much, practically all flow could have been utilized with the storage and draft rate shown. As this is the maximum draft rate, any smaller storage with a lesser draft rate could be designed.

The suitability of water from Daloelaeb, Peemgoy and Taalgum Streams for domestic use was shown by chemical analyses of the streamflow (tables 51-53, in the Hydrologic Data section).

Sunn, Low, Tom and Hara, Inc. (1971) proposed a dam below the gaging station site on Mukong Stream, Gagil-Tamil. Concluding that development of adequate ground-water sources would not be feasible, they suggested the following:

Consideration, therefore, is given to the development of surface waters flowing through the large central valley of Tomil. The drainage area is relatively large and the terrain features appear conducive to the construction of a dam which could impound sufficient quantities of water to meet the needs of both Tomil and Gagil. 


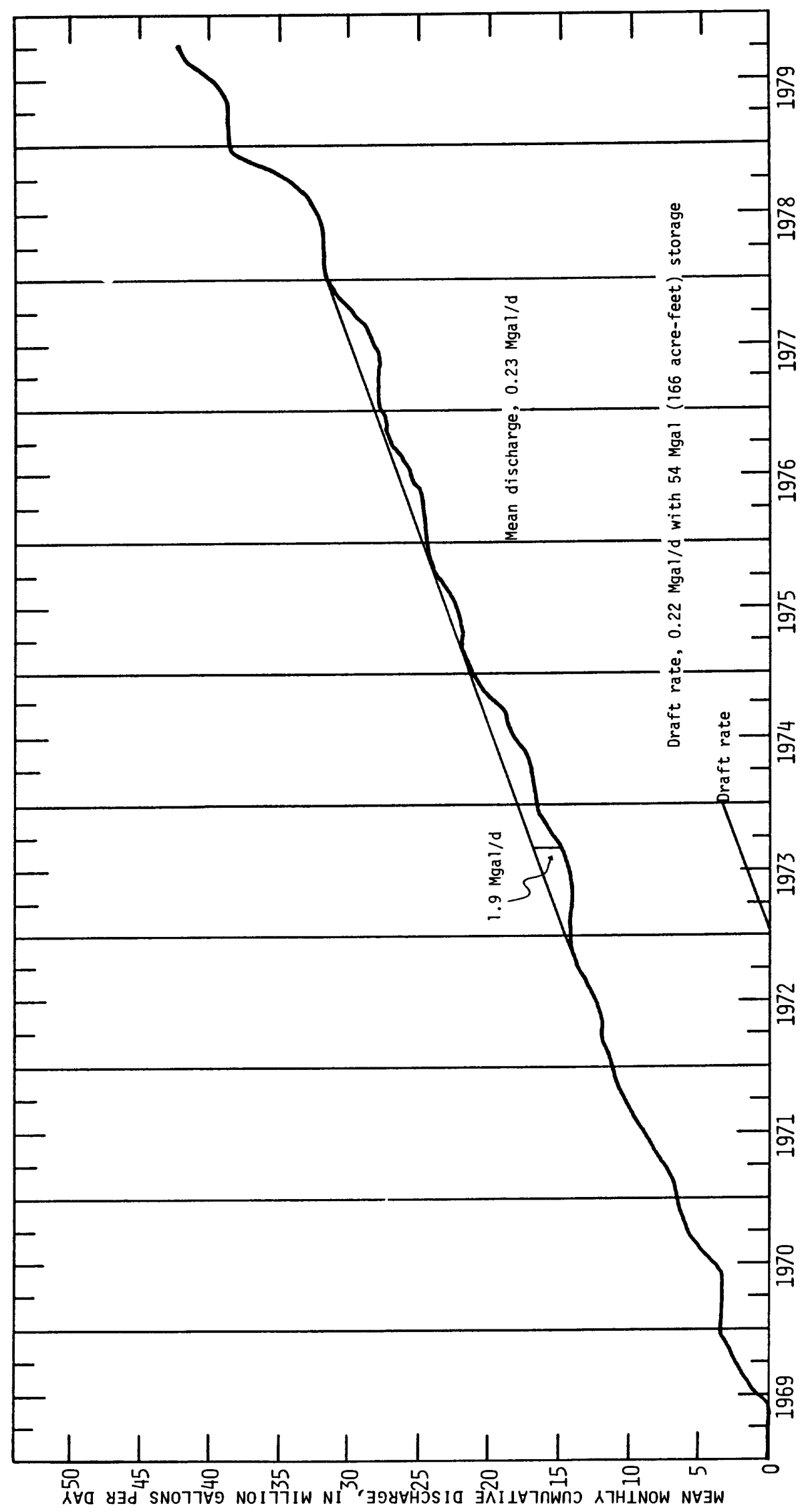

69 


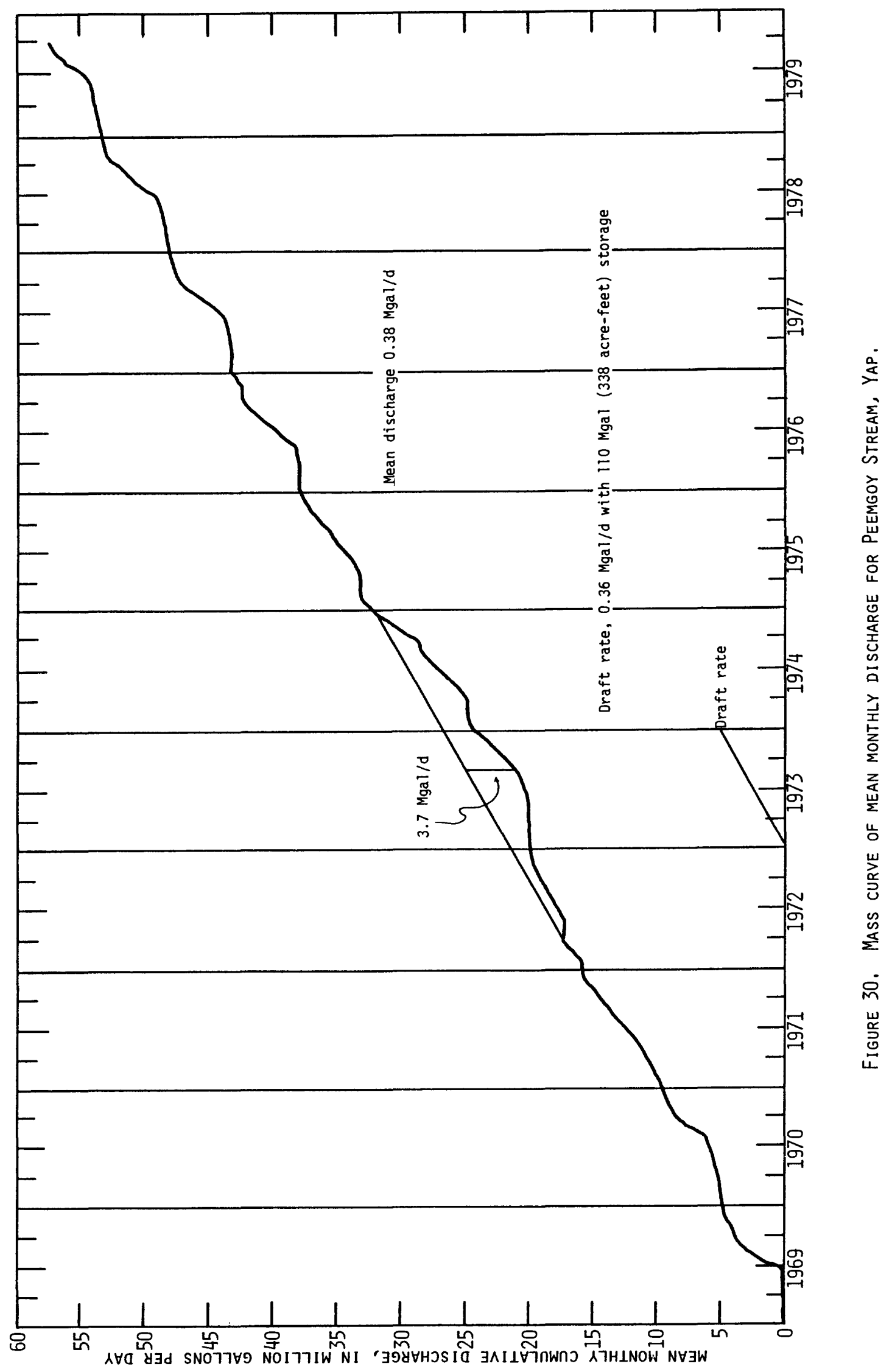




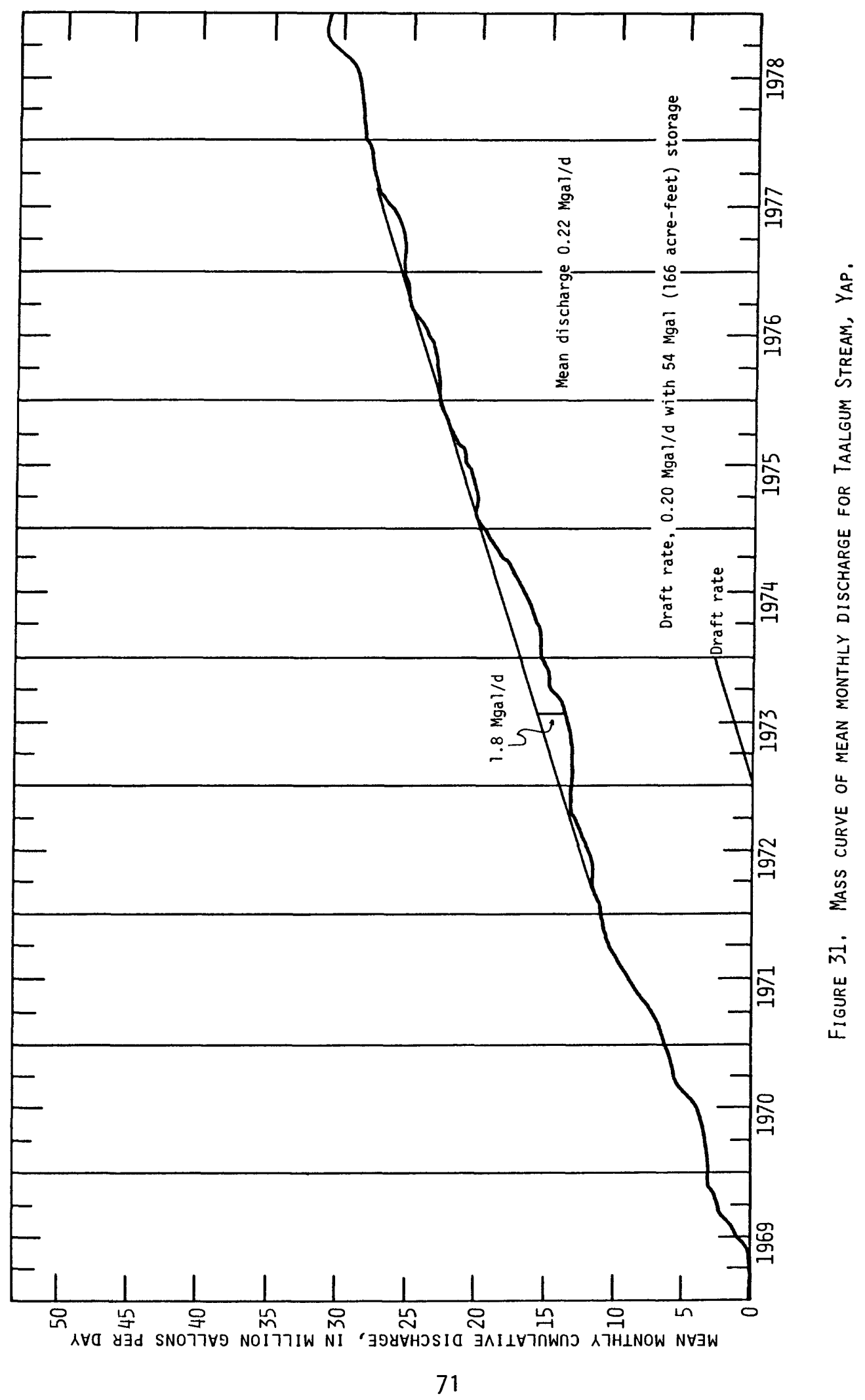


Studies based on U.S. Geological Survey maps indicate that a 10-foot high earthen dam located near Maa' village could impound approximately 4.0 million gallons of water, or the equivalent of about 10 weeks storage capacity at present design water consumption rates for Tomil and Gagil. The dam would consist of an earth embankment with an impermeable core, a concrete spillway to pass excess flows, and a low level sluice pipe. Initially the dam would span approximately 600 feet, be 10 feet high from the lowest point of the river, and have a top width of 20 feet. The dam height could easily be raised to provide increased storage capacities and to accomodate future water requirements. Initial water treatment facilities could consist of infiltration galleries which would filter the water prior to chlorination. As water consumption increases, water treatment facilities could be modified or expanded to meet increased demands. Gasoline powered pumps will deliver the treated water through transmission mains to reservoirs located in Tomil and Gagil. Two 100,000 gallon reservoirs are proposed, each providing approximately 5 days storage capacity. One reservoir shall be sited on a high point near Tomil School and the other reservoir sited in Gachpar village, Gagil. Transmission lines will then convey water to community distribution facilities in the village.

It should be noted that all recommendations were made before any streamflow data were available.

\section{Rain Catchments}

Although Yapese do not use much water for drinking (coconut water and canned drinks are preferred), some rainwater always has been collected mainly for food preparation. Runoff from roofs or palms is stored in cans, bottles, drums, and various other containers. Because of an average yearly rainfall of more than 120 inches, the use of roofs for rain catchment should provide a good source of water. However, as the rainfall is seasonal, storage is required for water during the dry season.

Small concrete reservoirs (usually $6 \times 6 \times 8$ feet, with a spigot at the base) were built in many villages during the Japanese Administration, but few, if any, are still in use. These reservoirs were filled by rainwater from the roofs of government buildings.

In Colonia, where most of the larger buildings are, few roofs have been used for rain catchments. Because of the cost of constructing many separate storage facilities, their maintenance, prevention of contamination and treatment required, a public water system is preferred. To provide areas outside Colonia with a public water system would be difficult, so the supply of water in these areas will probably come mainly from individual rain catchments or from small scale local development of spring or streamflow. 
To project a water supply derived from a roof catchment, mass curves were drawn for the dry periods during 2 years of average rainfall $(1960,1965)$ and for 2 extremely dry years $(1966,1973)$.

On figures 32-35, the draft rates for these years are shown for a catchment area of $100 \mathrm{ft}^{2}$ with storage facilities of 100,200 , and $300 \mathrm{gallons}$, assuming 100 percent recovery.

Similar determinations were made for catchment areas of 200 and $300 \mathrm{ft}^{2}$, and the results are given in tables 15 and 16 . 


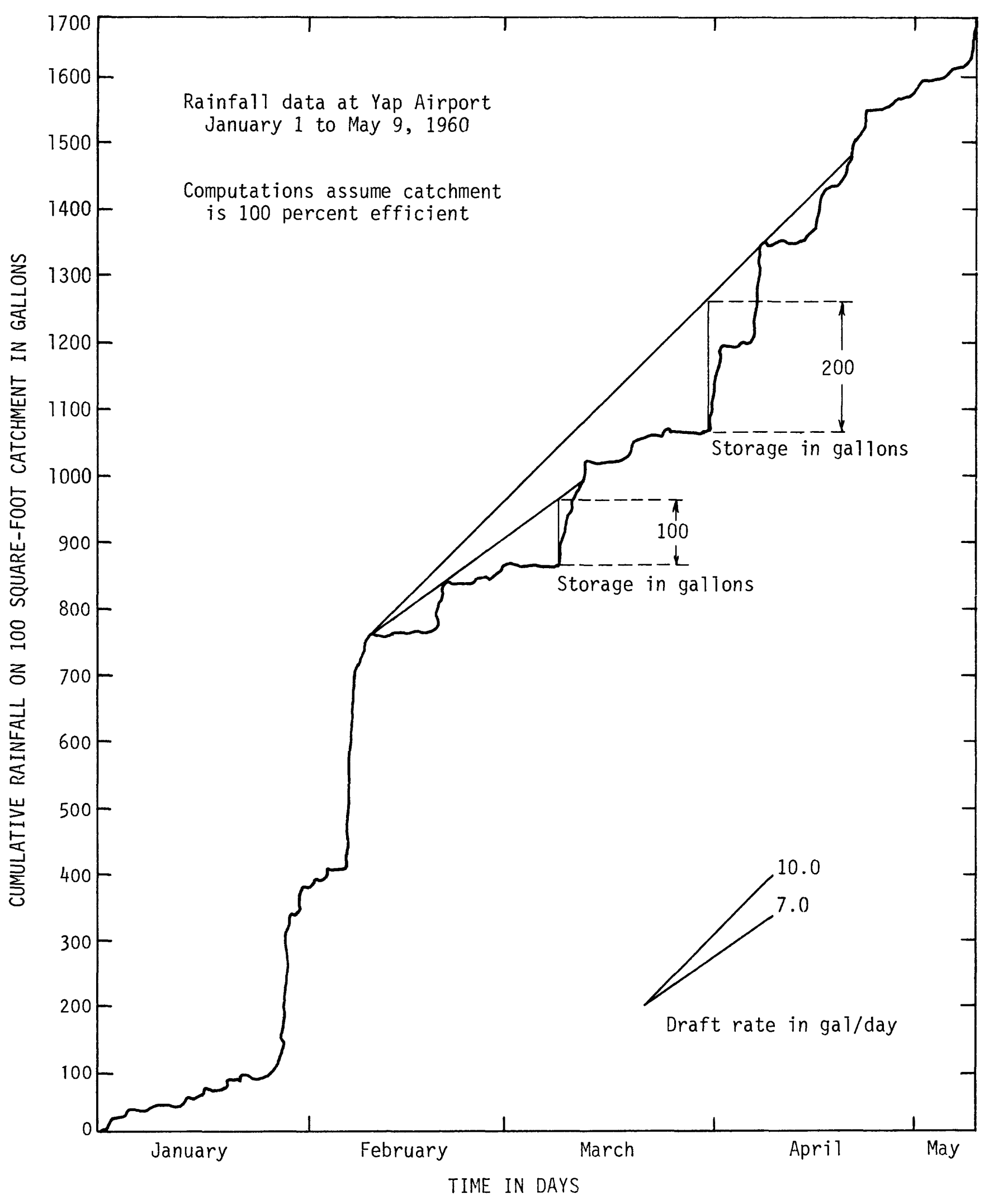

Figure 32. Determination of daily draft rates and storage requirements for rainfall catchment in Yap Islands for the dry period in a year with average rainfall (1960). 


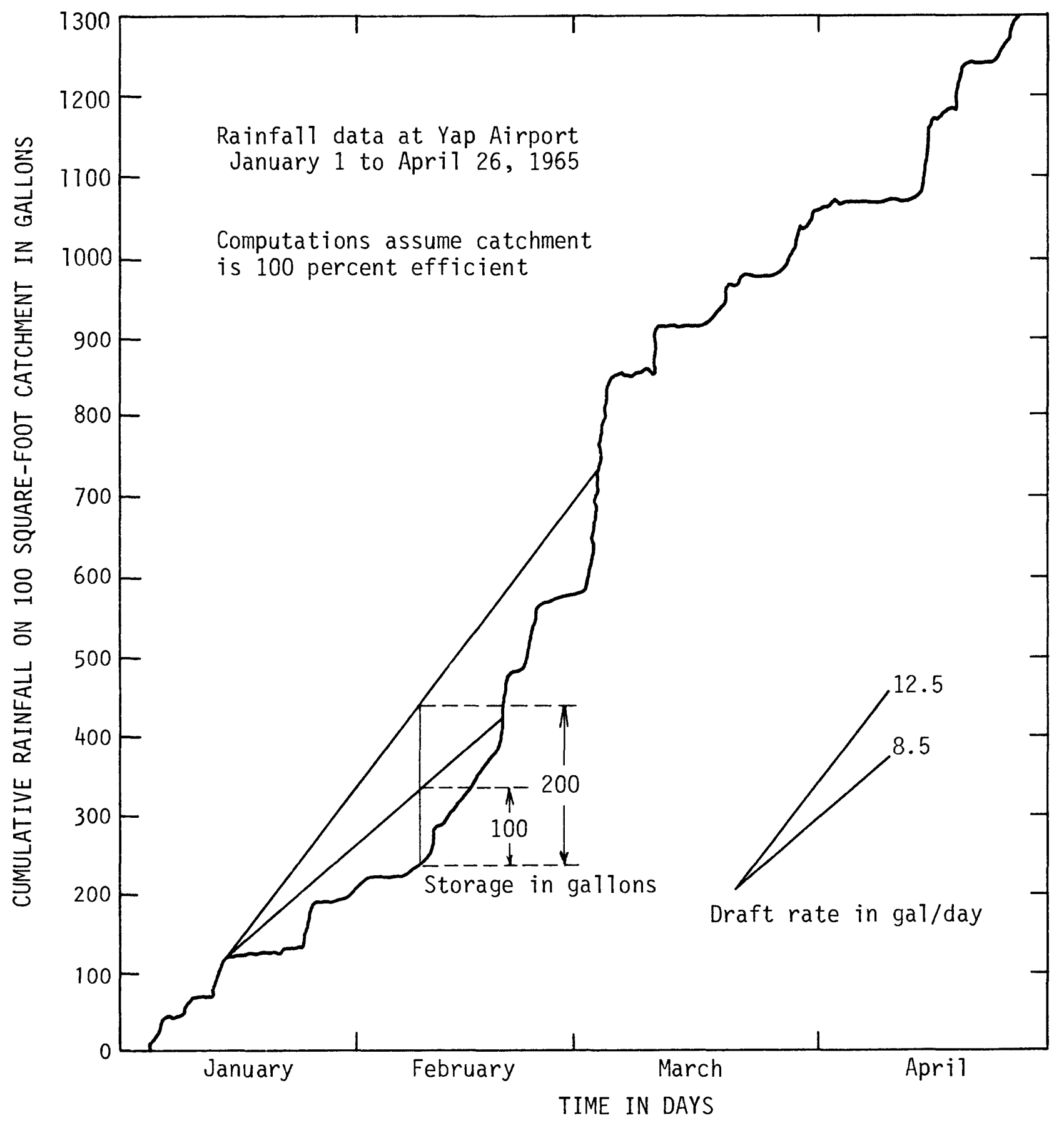

Figure 33. Determination of daily draft rates and storage requirements for rainfall catchment in Yap Islands for the period in a year with average rainfall (1965). 


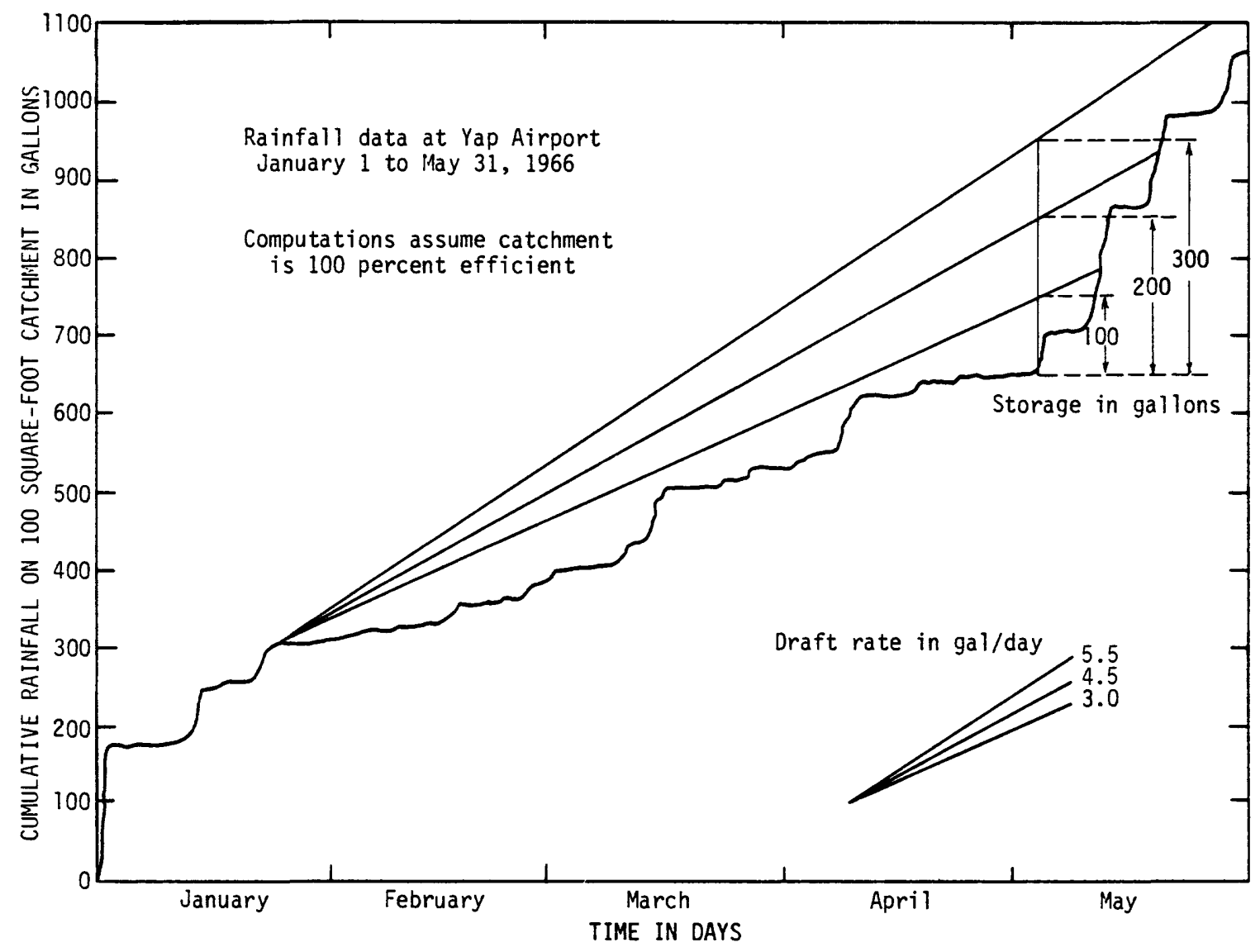

Figure 34. Determination of daily draft rates and storage requirements for rainfall catchment in Yap Islands for the dry period in a very dry year (1966). 


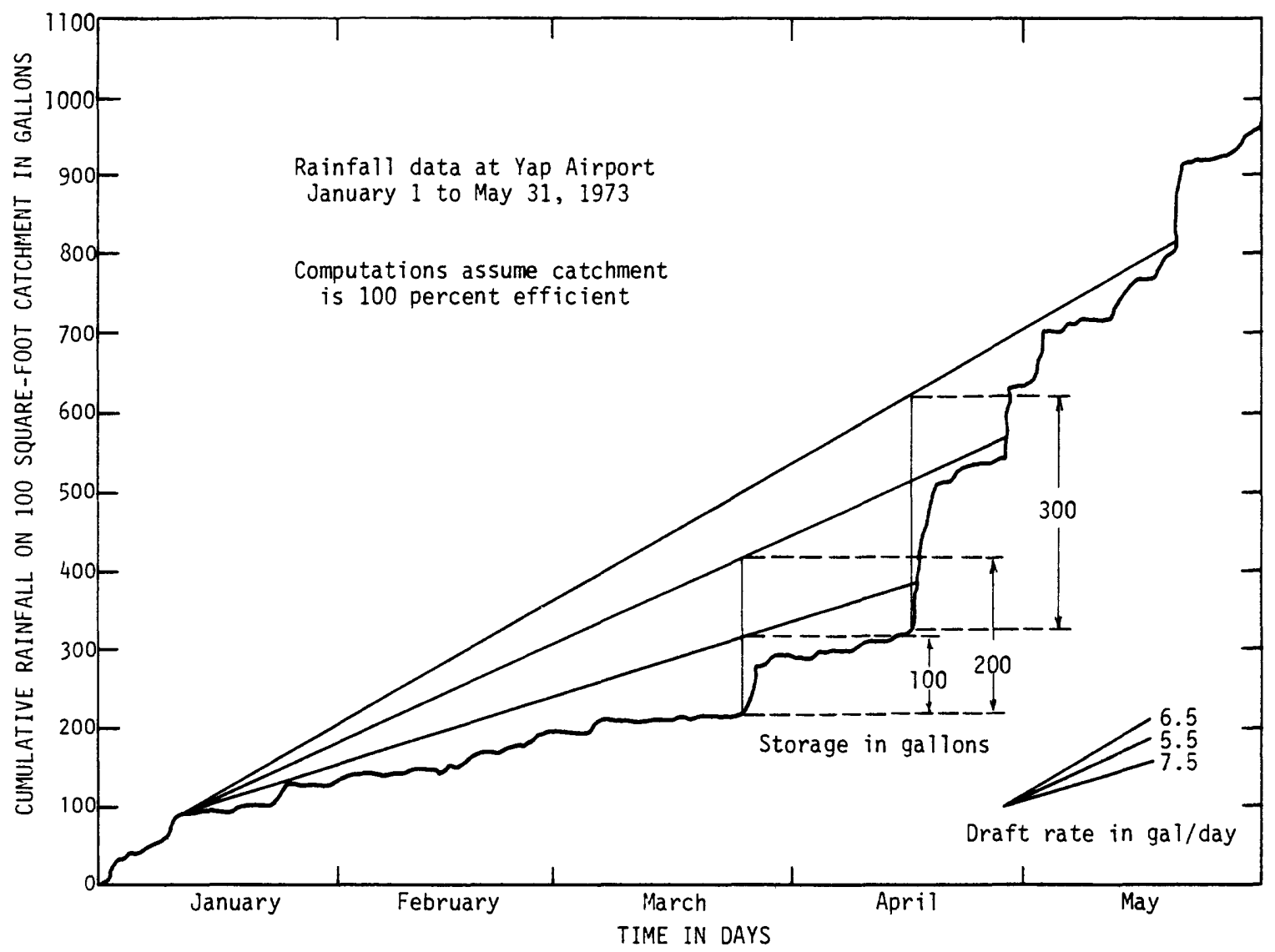

Figure 35. Determination of daily draft rates and storage requirements for rainfall catchment in Yap Islands for the dry period in a very dry year (1973). 
Table 15. Draft rate, in gallons, for available storage for several catchment sizes during the dry period of years with average rainfall

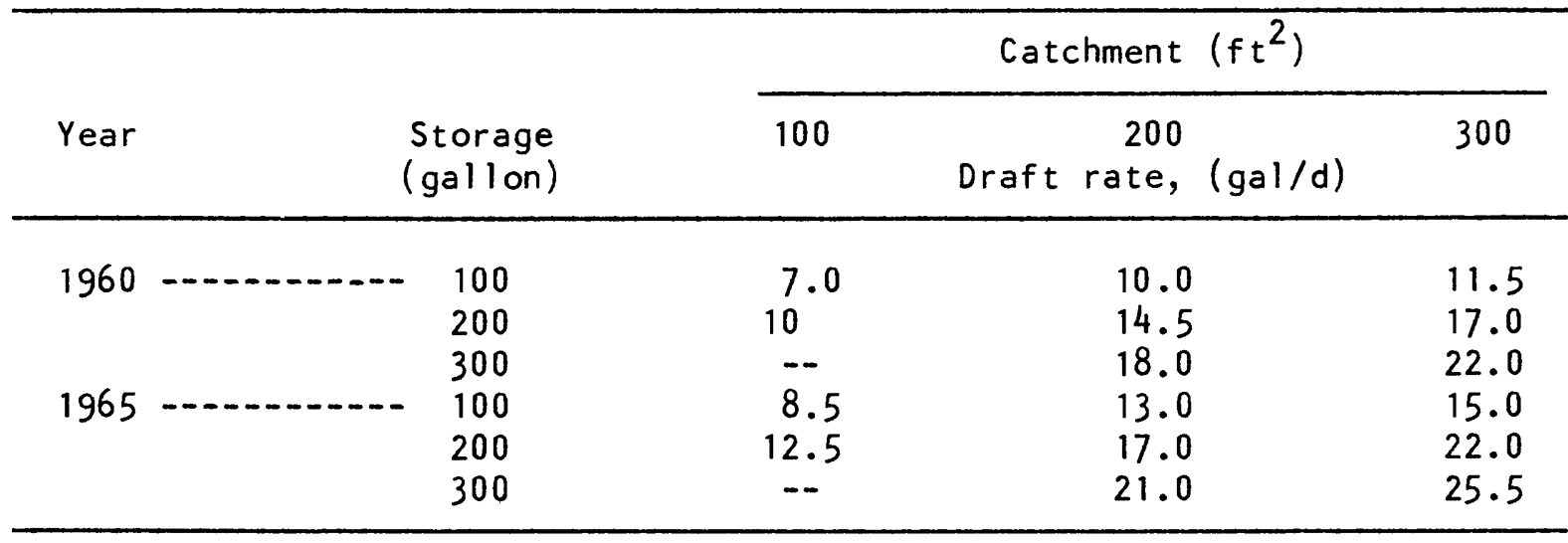

Table 16. Draft rate, in gallons, for available storage for several catchment sizes during very dry years

\begin{tabular}{|c|c|c|c|c|}
\hline \multirow[b]{2}{*}{ Year } & \multirow[b]{2}{*}{$\begin{array}{l}\text { Storage } \\
\text { gallon) }\end{array}$} & \multicolumn{3}{|c|}{ Catchment $\left(\mathrm{ft}^{2}\right)$} \\
\hline & & 100 & $\begin{array}{l}200 \\
\text { Draft rate, (gal/d) }\end{array}$ & 300 \\
\hline $\begin{array}{l}1966 \\
\text { (January- } \\
\text { May) } \\
1973 \\
\text { (January- } \\
\text { May) }\end{array}$ & $\begin{array}{l}100 \\
200 \\
300 \\
100 \\
200 \\
300\end{array}$ & $\begin{array}{l}4.5 \\
5.5 \\
6.5 \\
3.0 \\
4.5 \\
5.5\end{array}$ & $\begin{array}{r}6.6 \\
9.0 \\
10.0 \\
5.0 \\
6.5 \\
8.0\end{array}$ & $\begin{array}{r}8.0 \\
12.5 \\
13.5 \\
6.5 \\
8.0 \\
9.5\end{array}$ \\
\hline
\end{tabular}




\section{SUMMARY}

As the population of the Yap Islands continues to increase and the demand for water keeps growing, additional sources of water will have to be developed.

The largest amount of water available is from surface water. However, as all streams on the Island of Yap are dry part of the year, storage facilities would have to be constructed. Water from these reservoirs would be needed for the Central Water Supply System in and around Colonia. In a few areas, ground water would be available for small-scale development and local distribution. This could be supplemented by water from seeps and small streams and in many areas on Gagil-Tamil by diversions from some of the perennial streams.

For all areas outside the Colonia Central Water System, individual rain catchments from the roofs of dwellings should be encouraged. Because no single water source will be able to provide the needed water supply, it will be necessary to combine all available sources in each area to meet the demand. 
HYDROLOGIC DATA

Rainfall

Page

German rainfall records on

Rumung, 1899-1900 84

Yap Island, 1901-14 84

Japanese rainfall records on Yap Island, 1915-43 85

U.S. National Weather Service rainfall record on Yap Island, 1948-83

U.S. Coast Guard rainfall records on Gagil-Tamil, 1969-73, $1976 \ldots$

U.S. Geological Survey rainfall records at

Protestant Mission, Colonia, Yap, 1974-76, 1978

Taalgum Stream, Yap, 1974-79 89

LORAN station, Gagil-Tamii, 1981-83 91

\section{Evaporation}

Evaporation data for Guam (1956-82) and Yap (1978-82) 93

\section{Air Temperatures}

Air temperatures on Yap Island

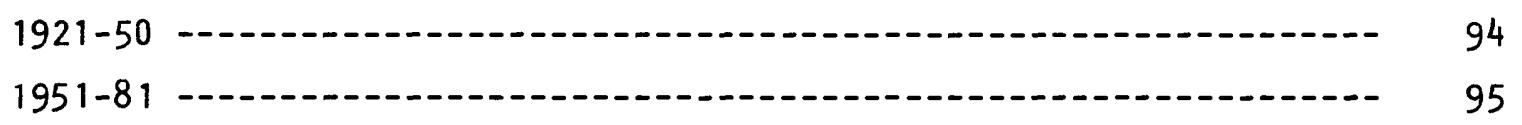




\section{Streamflow Records}

\section{Gaging stations}

In tables 28-36, peak discharges, annual minimum discharges, and annual discharges are given for the following gaging stations:

Page

16892000 Qatliw (Atelu) Stream, Yap, 1982

16892400 Qaringeel (Aringel) Stream, Yap, 1968-82 - 98

16892800 Daloelaeb (Dalolab) Stream, Yap, 1968-81_- 103

16892900 Peemgoy (Pemgoy) Stream, Yap, 1968-82 108

16893000 Taalgum (Talagu) Stream, Yap, 1968-79

16893100 Burong Stream, Yap, 1968-82 118

16893200 Mukong Stream, Gagil-Tamil, 1974-82 123

16893300 Gilaew (Bileiy) Spring, Gagil-Tamil, 1968-74_a. 128

16893400 Eyeb Stream, Gagil-Tamil, 1982

\section{Low-flow partial-record stations}

In tables 37-47, the discharge measurements made at the following low-flow partial-record stations are listed:

16892450 Faraq (Fara) Swamp outlets, Yap, 1968-73

16892460 Galngun Swamp outlet, Yap, 1968-73 133

16892500 Tamaney Stream, Yap, 1968-82 134

16892600 Ripu Stream, Yap, 1968-82 135

16892650 Dinaey (Dinay) Stream, Yap, 1980-82 136

16892700 Tholomar (Thalomar) Stream, Yap, 1965, 1968-74, 1980-82 137

16893050 Mabuuq (Mabu) Stream, Yap, 1968-72 138

16893180 Monguch Stream, Gagil-Tamil, 1979-82 _._. 139

16893310 Gilaew (Bileiy) Stream, Gagil-Tamil, 1968-80

16893350 Yanbilang Stream, Gagil-Tamil, 1968-72

16893500 Qamin (Amin) Stream, Maap, 1980-81_... 142

Miscellaneous measurements

Discharge measurements made at miscellaneous sites 


\section{Water Quality}

\section{Chemical analyses}

Tables 49-60 list the physical properties and constituents of water samples collected and analyzed by the U.S. Geological Survey during 1979-82 for the following locations:

Page

16892000 Qatliw (Atelu) Stream, Yap 144

16892400 Qaringeel (Aringel) Stream, Yap

16892500 Tamaney Stream, Yap 152

16892600 Ripu Stream, Yap 152

16892650 Dinaey (Dinay) Stream, Yap 152

16892680 Tholomar (Thalomar) Stream, Yap 152

16892800 Daloelaeb (Dalolab) Stream, Yap

16892900 Peemgoy (Pemgoy) Stream, Yap 147

16893000 Taalgum (Talagu) Stream, Yap 148

16893100 Burong Stream, Yap

16893180 Monguch Stream, Gagil-Tamil 153

16893190 Dorfay Stream, Gagil-Tamil 153

16893200 Mukong Stream, Gagil-Tamil 150

16893300 Gilaew (Bileiy) Spring, Gagil-Tamil 153

16893400 Eyeb Stream, Gagil-Tamil 151

16893500 Qamin (Amin) Stream, Maap

Water-treatment plant, Yap 154

Airport Swamp, Yap - 154

Timlang 3 well, Yap

Lamaer well , Yap - 155

Communication Station well, Yap 155

Mitsui well, Yap - 155

Monguch 1 well, Gagil-Tamil 155 


\section{Water temperatures}

Water temperatures and instantaneous discharge obtained at the following gaging station and low-flow partial-record station sites are given in tables 62-81. Concurrent air temperatures are listed where available.

\begin{tabular}{|c|c|}
\hline 16892000 & Qatliw (Atelu) Stream, Yap \\
\hline 16892400 & Qar ingeel (Aringel) Stream, Yap \\
\hline 16892450 & Faraq (Fara) Swamp outlets, Yap --- \\
\hline 16892460 & Galngun Swamp outlet, Yap \\
\hline 16892500 & Tamaney Stream, Yap \\
\hline 16892600 & Ripu Stream, Yap \\
\hline 16892650 & Dinaey (Dinay) Stream, Yap \\
\hline 16892680 & Tholomar (Thalomar) Stream, Yap - \\
\hline 16892800 & Daloelaeb (Dalolab) Stream, Yap -..- \\
\hline 16892900 & Peemgoy (Pemgoy) Stream, Yap \\
\hline 16893000 & Taalgum (Talagu) Stream, Yap \\
\hline 16893050 & Mabuuq (Mabu) Stream, Yap \\
\hline 16893100 & Burong Stream, Yap \\
\hline 16893180 & Monguch Stream, Gagil-Tamil -..- \\
\hline 16893200 & Mukong Stream, Gagil-Tamil \\
\hline 16893300 & Gilaew (Bileiy) Spring, Gagil-Tamil \\
\hline 16893310 & Gilaew (Bileiy) Stream, Gagil-Tamil \\
\hline 16893350 & Yanbilang Stream, Gagil-Tamil \\
\hline 16893400 & Eyeb Stream, Gagil-Tamil $\ldots$ \\
\hline 16893500 & Qamin (Amin) Stream, Maap \\
\hline
\end{tabular}


Table 17. Monthly and annual rainfall, in inches, during the German Administration

[Converted from millimeters to inches]

Rumung

Source: "Mittheilungen von Forschungreisenden und Gelehrten aus den deutschen Schutzgebieten", 1901.

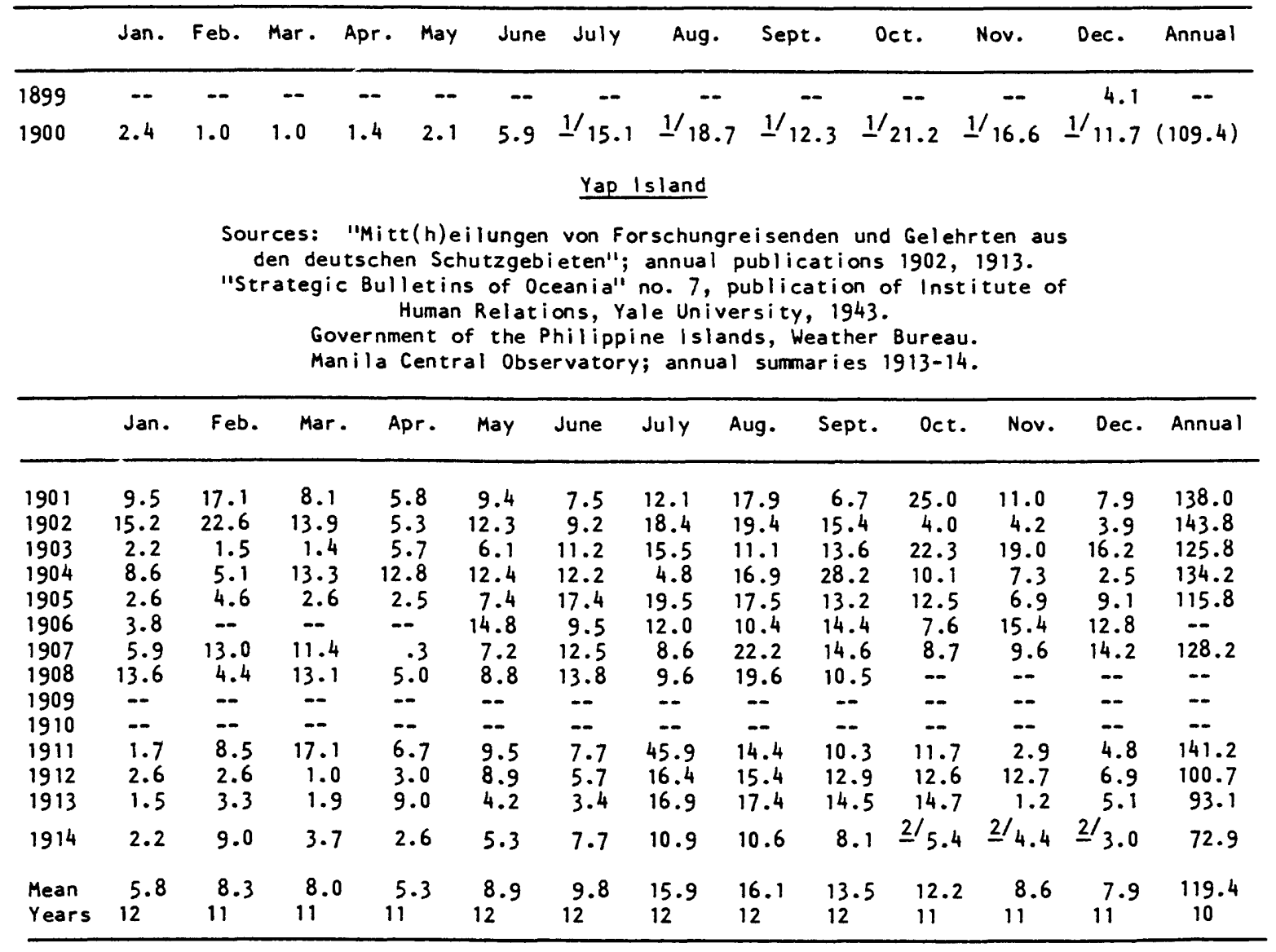

$1 /$ Publications do not report date of change of location to Yap Island. Name of observer from June 22, 1900 is the same as for 1901, 1902. For 1901, latitude and longitude were given for the Yap Island location.

2/ October to December 1914 included in German period although the Yap Islands were al ready occupied by Japan. 
Table 18. Monthly and annual rainfall, in inches, during the Japanese Administration

[Converted from millimeters to inches]

Sources: Government of the Philippine |slands, Weather Bureau, Manila Central

Observatory; annual summaries, 1915-20.

"World Weather Records," publication of Smithsonian Institution, 1934, $(1921-30)$, and $1947,(1931-40)$.

U.S. Weather Bureau, 1959 (1941-43).

\begin{tabular}{|c|c|c|c|c|c|c|c|c|c|c|c|c|c|}
\hline & Jan. & Feb. & Mar. & Apr. & May & June & July & lug. & Sept. & Oct. & Nov. & Dec. & Annual \\
\hline $\begin{array}{l}1915 \\
1916 \\
1917 \\
1918 \\
1919 \\
1920 \\
1921 \\
1922 \\
1923 \\
1924 \\
1925 \\
1926 \\
1927 \\
1928 \\
1929 \\
1930 \\
1931 \\
1932 \\
1933 \\
1934 \\
1935 \\
1936 \\
1937 \\
1938 \\
1939 \\
1940 \\
1941 \\
1942 \\
1943\end{array}$ & $\begin{array}{r}3.2 \\
13.9 \\
8.7 \\
10.3 \\
2.5 \\
9.2 \\
3.8 \\
9.1 \\
11.4 \\
2.6 \\
3.6 \\
18.1 \\
5.0 \\
3.9 \\
16.7 \\
6.0 \\
5.3 \\
5.4 \\
2.3 \\
6.9 \\
7.8 \\
4.9 \\
3.3 \\
8.0 \\
10.1 \\
5.8 \\
4.6 \\
6.0 \\
19.3\end{array}$ & $\begin{array}{r}0.7 \\
17.6 \\
4.2 \\
7.6 \\
2.3 \\
9.5 \\
1.6 \\
2.8 \\
6.2 \\
1.2 \\
3.8 \\
3.7 \\
13.0 \\
4.8 \\
5.8 \\
4.5 \\
1.6 \\
7.1 \\
7.7 \\
6.4 \\
4.4 \\
1.8 \\
3.2 \\
3.2 \\
5.5 \\
6.8 \\
2.4 \\
1.2 \\
5.5\end{array}$ & $\begin{array}{c}2.9 \\
12.0 \\
6.8 \\
4.1 \\
2.4 \\
3.7 \\
-.- \\
8.4 \\
6.6 \\
1.0 \\
1.4 \\
2.1 \\
3.6 \\
4.2 \\
.8 \\
1.3 \\
1.0 \\
10.4 \\
3.5 \\
7.3 \\
5.7 \\
8.5 \\
5.5 \\
4.7 \\
2.9 \\
5.7 \\
3.0 \\
2.2 \\
4.5\end{array}$ & $\begin{array}{r}2.8 \\
7.7 \\
2.8 \\
12.7 \\
2.4 \\
2.8 \\
9.2 \\
3.0 \\
5.1 \\
3.1 \\
4.6 \\
.2 \\
5.0 \\
5.7 \\
10.6 \\
3.4 \\
3.0 \\
2.6 \\
7.7 \\
7.9 \\
6.9 \\
4.4 \\
6.4 \\
8.3 \\
7.6 \\
15.2 \\
1.0 \\
5.4 \\
9.5\end{array}$ & $\begin{array}{r}11.9 \\
13.2 \\
12.2 \\
3.7 \\
7.8 \\
8.6 \\
13.2 \\
5.3 \\
11.0 \\
8.7 \\
8.1 \\
2.6 \\
8.7 \\
19.3 \\
8.1 \\
8.4 \\
9.2 \\
15.8 \\
8.9 \\
7.0 \\
10.2 \\
14.6 \\
6.5 \\
12.1 \\
9.8 \\
4.9 \\
12.1 \\
7.6 \\
9.9\end{array}$ & $\begin{array}{r}15.6 \\
15.8 \\
7.9 \\
8.9 \\
2 / 4.4 \\
10.5 \\
7.8 \\
9.1 \\
20.8 \\
9.4 \\
8.9 \\
10.6 \\
9.6 \\
13.4 \\
5.2 \\
16.1 \\
5.9 \\
7.9 \\
6.9 \\
9.0 \\
6.9 \\
8.5 \\
10.2 \\
11.9 \\
4.4 \\
16.5 \\
15.0 \\
6.5 \\
15.3\end{array}$ & $\begin{array}{r}12.2 \\
9.5 \\
13.9 \\
19.6 \\
16.7 \\
31.1 \\
8.7 \\
11.8 \\
24.9 \\
19.7 \\
22.0 \\
13.5 \\
25.7 \\
16.6 \\
15.9 \\
26.9 \\
9.5 \\
21.1 \\
14.5 \\
14.6 \\
15.3 \\
20.2 \\
10.8 \\
14.3 \\
15.5 \\
24.4 \\
14.2 \\
17.9 \\
18.5\end{array}$ & $\begin{array}{r}18.8 \\
9.8 \\
9.0 \\
17.9 \\
19.1 \\
11.8 \\
10.9 \\
19.1 \\
28.1 \\
11.6 \\
20.2 \\
22.2 \\
25.5 \\
6.6 \\
16.3 \\
16.9 \\
14.3 \\
7.8 \\
8.8 \\
25.0 \\
8.6 \\
22.4 \\
19.0 \\
8.1 \\
14.7 \\
32.1 \\
20.4 \\
19.0 \\
11.2\end{array}$ & $\begin{array}{r}5.8 \\
17.7 \\
17.5 \\
8.0 \\
10.4 \\
8.1 \\
10.7 \\
19.3 \\
12.2 \\
11.4 \\
8.3 \\
16.4 \\
7.7 \\
18.6 \\
10.6 \\
19.0 \\
15.2 \\
18.7 \\
9.5 \\
15.6 \\
20.3 \\
15.9 \\
11.2 \\
20.4 \\
16.5 \\
14.5 \\
12.2 \\
13.9 \\
16.2\end{array}$ & $\begin{array}{r}12.8 \\
15.3 \\
8.3 \\
8.7 \\
11.6 \\
10.3 \\
10.2 \\
5.7 \\
7.4 \\
15.2 \\
22.6 \\
17.1 \\
8.6 \\
11.4 \\
14.4 \\
6.7 \\
22.9 \\
9.5 \\
24.0 \\
11.1 \\
9.9 \\
14.6 \\
17.7 \\
12.6 \\
17.8 \\
6.8 \\
3.7 \\
12.2 \\
10.9\end{array}$ & $\begin{array}{r}8.4 \\
13.3 \\
11.7 \\
7.7 \\
10.1 \\
8.9 \\
13.9 \\
8.8 \\
7.2 \\
22.5 \\
7.9 \\
9.9 \\
13.2 \\
10.0 \\
9.1 \\
9.0 \\
19.4 \\
6.7 \\
10.7 \\
14.7 \\
12.7 \\
3.6 \\
8.0 \\
10.1 \\
17.3 \\
8.6 \\
11.0 \\
5.2 \\
14.4\end{array}$ & $\begin{array}{r}14.4 \\
6.4 \\
9.4 \\
5.9 \\
6.8 \\
(3) \\
12.2 \\
10.1 \\
6.5 \\
13.8 \\
414.3 \\
14.6 \\
6.6 \\
12.9 \\
2.2 \\
6.2 \\
19.4 \\
10.9 \\
18.8 \\
10.2 \\
8.0 \\
6.8 \\
6.6 \\
5.9 \\
23.1 \\
5.4 \\
7.6 \\
7.4 \\
10.4 \\
8.2\end{array}$ & $\begin{array}{c}1 / 109.4 \\
152.2 \\
112.4 \\
2114.7 \\
236.5 \\
-- \\
-- \\
112.5 \\
147.4 \\
120.2 \\
125.7 \\
123.0 \\
138.6 \\
116.7 \\
119.7 \\
137.6 \\
118.2 \\
131.8 \\
114.5 \\
133.5 \\
115.5 \\
126.0 \\
107.7 \\
136.8 \\
127.5 \\
148.9 \\
107.0 \\
107.5 \\
143.4\end{array}$ \\
\hline $\begin{array}{l}\text { Mean } \\
\text { Years } \\
\text { Per- } \\
\text { cent }\end{array}$ & $\begin{array}{c}7.5 \\
29 \\
6.1\end{array}$ & $\begin{array}{l}5.0 \\
29 \\
4.1\end{array}$ & $\begin{array}{r}2^{4} .5 \\
3.6\end{array}$ & $\begin{array}{l}5.8 \\
29 \\
4.7\end{array}$ & $\begin{array}{c}9.6 \\
29\end{array}$ & $\begin{array}{l}10.3 \\
29\end{array}$ & $\begin{array}{l}17.2 \\
29\end{array}$ & $\begin{array}{l}16.4 \\
29\end{array}$ & $\begin{array}{l}13.9 \\
29\end{array}$ & $\begin{array}{l}12.4 \\
29\end{array}$ & $\begin{array}{l}10.8 \\
29 \\
8.8\end{array}$ & ${ }_{28}^{9.9}$ & $\begin{array}{c}123.9 \\
27\end{array}$ \\
\hline
\end{tabular}

1/ 1 day missing.

2/ 4 days missing.

(3) Rain gage destroyed by typhoon of Dec. 17, 1920.

4/ Rain gage destroyed by typhoon of Dec. 15, 1925 after 2 p.m.. Replaced on Dec. 16.

Total of monthly means: 123.3 inches. 
Table 19. Monthly and annual rainfall, in inches, for the period 1948-83

Obtained by U.S. Navy during 1948-51 and by National Weather Service since 1952 (U.S. National Oceanic and Atmospheric Administration, 1981, 1982-83).

Location: 1948 to March 1968, lat $9^{\circ} 31^{\prime}$, long $138^{\circ} 08^{\prime}$ (next to Raiview Hotel).

Location: March 1968 to present, lat $9^{\circ} 29^{\prime}$, long $138^{\circ} 05^{\prime}$, altitude $44 \mathrm{ft}$, at Yap Airfield.

A 4-inch rain gage was used to Dec. 31,1953 and an 8-inch gage thereafter.

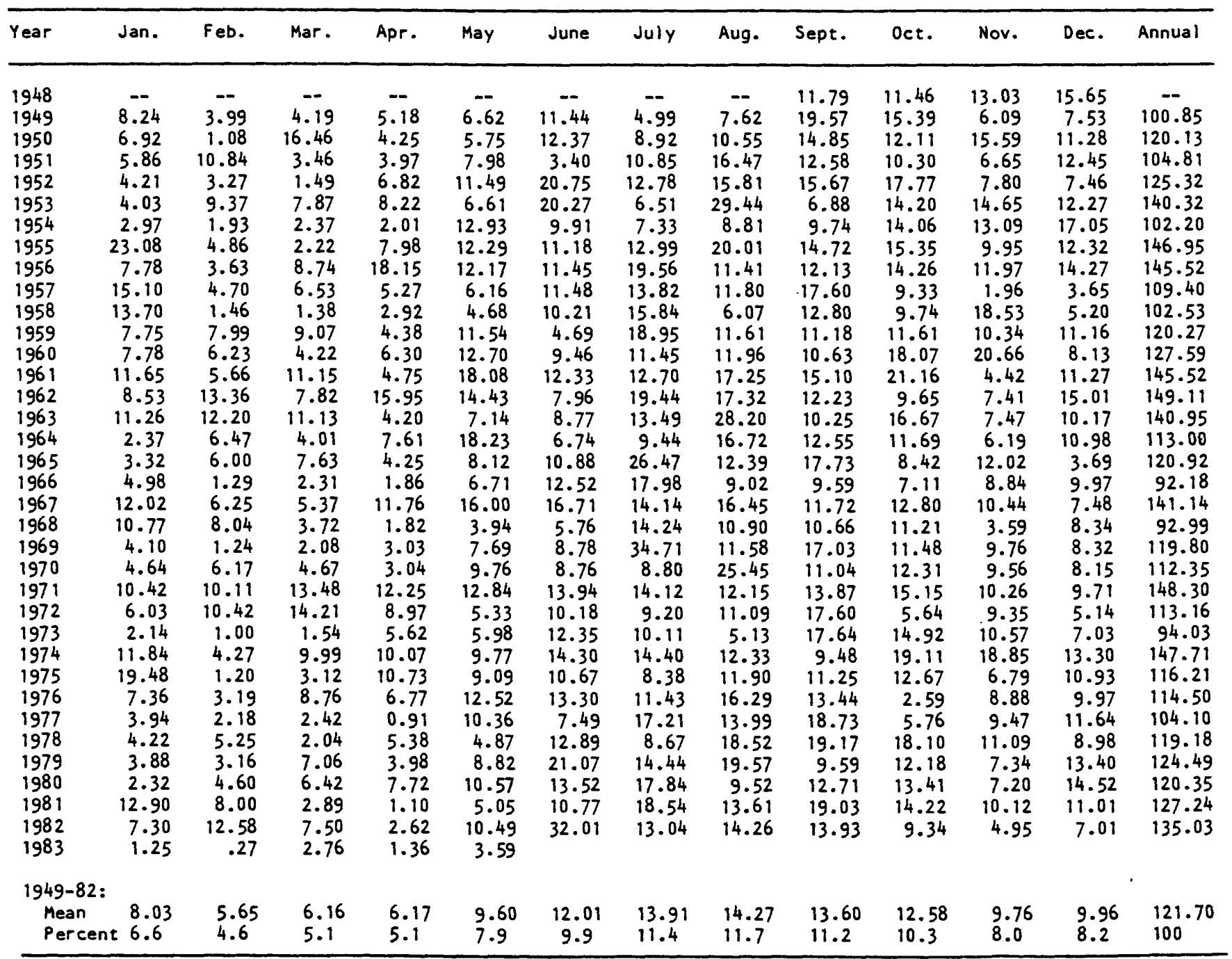


Table 20. Mean monthly rainfall, in inches, for a period of 27-28 years

prior to 1938 (years not identified)

Location: Lat $9^{\circ} 30^{\prime} \mathrm{N}$., long $138^{\circ} 08^{\prime} \mathrm{E}$.

Source: "Sailing Directions for the Pacific Islands," U.S. Navy

Department, Hydrographic Office, 1938.

\begin{tabular}{lllllllllllll}
\hline Jan. & Feb. & Mar. & Apr. & May & June July & Aug. & Sept. & Oct. & Nov. & Dec. & Annual \\
\hline 6.54 & 5.89 & 4.98 & 5.11 & 9.99 & 9.89 & 16.88 & 16.35 & 12.54 & 11.81 & 9.97 & 9.08 & 119.03 \\
\hline
\end{tabular}

Table 21. Monthly and annual rainfall, in inches, at Gagil-Tamil, 1969-73, 1976

Source: U.S. Coast Guard LORAN station, Gagil-Tamil

\begin{tabular}{lcrrrrr}
\hline Year & Jan. & Feb. & Mar. & Apr. & May & June \\
\hline 1969 & 4.68 & 2.32 & 2.30 & 4.38 & 13.46 & 9.42 \\
1970 & 4.22 & 5.00 & 4.55 & 4.06 & 11.94 & 11.56 \\
1971 & 9.65 & 10.29 & 11.95 & 10.29 & 16.99 & 13.38 \\
1972 & -- & -- & 9.52 & 8.60 & 2.61 & 10.65 \\
1973 & 1.11 & 1.09 & -- & -- & -- & -- \\
1976 & -- & -- & 5.18 & 8.96 & 12.64 & 14.91 \\
\hline
\end{tabular}

\begin{tabular}{lcccccccc}
\hline Year & July & Aug. & Sept. & Oct. & Nov. & Dec. & Annual \\
\hline 1969 & 23.38 & 12.30 & 11.91 & 12.25 & 12.08 & 10.78 & 119.26 \\
1970 & 10.70 & $* 4.10$ & $* 5.22$ & $* 4.82$ & $* 5.82$ & 7.58 & $* 79.56$ \\
1971 & 20.50 & 14.01 & 10.34 & 15.30 & 9.20 & 5.49 & 147.39 \\
1972 & 11.54 & 14.95 & 22.49 & 6.02 & 6.15 & 5.11 & -- \\
1973 & -- & -- & -- & -- & -- & -- & -- \\
1976 & 9.43 & 14.11 & 12.75 & 3.03 & 7.12 & 12.64 & -- \\
\hline
\end{tabular}

* Appears incorrect. 
Table 22. Cumulative rainfall readings, in inches, at Protestant Mission, Colonia, Yap

[Lat $9^{\circ} 30^{\prime} 44^{\prime \prime} \mathrm{N}$., long $138^{\circ} 07^{\prime} 29^{\prime \prime}$ E., near front of Mission Church in Colonia; altitude, $25 \mathrm{ft}$ (from topographic map)]

Period Rainfall Period Rainfall

$\underline{1974}$

Apr. 6-23 -

May $9-16$

May 16 to June 11 -..- 9.6

June 11 to July 11 -.-- 11.2
July 11-30

Sept. 14 to Oct. $10 \ldots-7.8$

Oct. 10. to Nov. 6 -...- 17.2

Nov. 6 to Dec. 6 -...- 11.2

1975

Apr. 26 to May 5 -..- 6.2

May $5-14$

May 14 to June $18 \ldots . .-8.0$

June 18 to July $14 \ldots \ldots$

July 14-29 _.._._._.- 1.8

July 29 to Aug. $15 \ldots$

1976

Dec. 23 to Jan. 9 -.---

1.7

2.7

1.2

0

5.0

1.0

4.5

2.3

$\begin{array}{lr}\text { Apr. } 20 \text { to May } 3-\cdots- & 1.6 \\ \text { May 3-20 } & -\end{array}$

$\begin{array}{lr}\text { Apr. } 20 \text { to May } 3-\ldots- & 1.6 \\ \text { May 3-20 } & \end{array}$
Jan. 19 to Feb. 3 -.-- 1.5

1.1

Apr. $1-12$

May 5-26 -

$\begin{array}{lll}\text { May } 26 \text { to June } 16 \ldots \ldots- & 6.2 \\ \text { June } 16-29 & \end{array}$

$\begin{array}{lll}\text { May } 26 \text { to June } 16 \ldots \ldots- & 6.2 \\ \text { June } 16-29 & \end{array}$

June 29 to July $25 \ldots$
Aug. 15-28

Aug. 28 to Sept. $22 \ldots-$-.- 5.9

Sept. 22 to Oct. 9 -..- 5.2

Oct. 9 to Nov. $5 \ldots . .-7.1$

Nov. 5 to Dec. $14 \ldots .1$

Dec. 4-23 - 4.0
May 20 to June $16 \ldots-\ldots$

June 16 to July 6 -...- 13.0

July 6-27 -.---.--- 11.0

July 27 to Aug. 11 -..- 6.5

Aug. 11-27 _...... 7.2

Aug. 27 to Sept. 17 -.- 10.9

Oct. 10 to Nov. 2 -.-.- 1.1

Nov. 2 to Dec. 3 -....- 10.9

Dec. 3-30 -.... 5.2

1978

July 25 to Aug. 30 -.-- 18.3

Aug. 30 to Sept. $19 \ldots 14.5$

Sept. 19-29 _- 2.8

Sept. 29 to Oct. 31 -.- 16.6

Oct. 31 to Nov. $30 \ldots-\ldots-7.7$

Nov. 30 to Dec. $12 \ldots-\ldots 5$

Dec. 12-28 _... 
Table 23. Cumulative rainfall readings, in inches, at Taalgum Stream,

[Lat $9^{\circ} 31^{\prime} 02^{\prime \prime} \mathrm{N} .$, long $138^{\circ} 06^{\prime} 33^{\prime \prime} \mathrm{E}$., on hillside along foot trail to

Taalgum River gaging station; altitude, $200 \mathrm{ft}$ (from topographic map)]

\begin{tabular}{llll}
\hline Period Rainfall & Period & Rainfall \\
\hline
\end{tabular}

1974

May 8-17 - 3.2

May 17 to June $11-\ldots--11.6$

June 11 to July $11 \ldots 12.0$

July 11-30 -......... 6.5
Sept. 12 to Oct. 10 -.- 7.5

Oct. 10 to Nov. 7 ...- 17.0

Nov. 7 to Dec. $12 \ldots-.-11.8$

Dec. 12-31 _....... 6.5

$\underline{1975}$

Jan. 1-12

Apr. 26 to May 5 -...- 5.3

May 6-14 -.......-.- 1.5

May 14 to June $17 \ldots \ldots$ 10...

June 17 to July $14 \ldots \ldots$

July 14-29 _........... 1.1

July 29 to Aug. $14 \ldots \ldots-12.8$
Aug. 14-28

Aug. 28 to Sept $22 \ldots . .5$

Sept. 22 to Oct. 9 ... 4.2

Oct. 9 to Nov. 5 ....- 8.0

Nov. 5 to Dec. 4 ..... 6.7

Dec. 4-23 _........ 4.4

1976

Dec. 23 to Jan. 9 -..- 1.5

Jan. 9-27 -........ 3.3

Jan. 27 to Feb. 3 -..- 1.6

Feb. 3-17 -......... 0

Feb. 17 to Mar. 2 -..- 7.0

Mar. 2-11 _........... 4.0

Mar. 11 to Apr. $2 \ldots . .5$

Apr. 2-20 _........ 8.0

Apr. 20 to May $3 \ldots 2.1$

May 3-20 -........... 11.0

May 20 to June $16 \ldots$

$\underline{1977}$

Dec. 30 to Jan. 21 -..- 2.2

June 7 to July 1 ..... 4.8

July to Aug. $16 \ldots 21.1$

Nov. 3-16
June 16 to July $6 \ldots \ldots$

July 6-27 -.......... 9.1

July 27 to Aug. 11 -.- 7.8

Aug. 11-27 -....... 9.0

Aug. 27 to Sept. 17 -.- 9.7

Oct. 10 to Nov. 2 .... 4.7

Nov. 2 to Dec. 3 ....- 10.5

Dec. 3-30 -...... 9.5

Total

Nov. 16-30 - 16.2

Nov. 30 to Dec. $16 \ldots . .8$

Dec. 16-29 
Table 23. Cumulative rainfall readings, in inches, at Taalgum Stream--Continued

\begin{tabular}{|c|c|c|c|c|}
\hline Period & Rainfall & & Period & Rainfall \\
\hline \multicolumn{5}{|c|}{1978} \\
\hline $\begin{array}{l}\text { Jan. } 19 \text { to Feb. } 3 \\
\text { Feb. } 3-23 \\
\text { Feb. } 23 \text { to Mar. } 16 \\
\text { Apr. } 1-12 \\
\text { May } 5-26 \\
\text { May } 26 \text { to June } 16 \\
\text { June } 16-29 \\
\text { June } 29 \text { to July } 25\end{array}$ & $\begin{array}{l}1.8 \\
3.2 \\
1.2 \\
5.0 \\
3.4 \\
5.1 \\
6.3 \\
7.0\end{array}$ & & $\begin{array}{l}\text { July } 25 \text { to Aug. } 30 \\
\text { Aug. } 30 \text { to Sept. } 19 \\
\text { Sept. } 19-29- \\
\text { Sept. } 29 \text { to Oct. } 31 \\
\text { Oct. } 31 \text { to Nov. } 15 \\
\text { Nov. } 15-30 \text { - } \\
\text { Nov. } 30 \text { to Dec. } 13 \\
\text { Dec. } 13-28\end{array}$ & $\begin{array}{r}21.2 \\
14.9 \\
3.2 \\
16.1 \\
6.5 \\
3.6 \\
5.9 \\
1.2\end{array}$ \\
\hline \multicolumn{5}{|c|}{1979} \\
\hline $\begin{array}{l}\text { Dec. } 28 \text { to Jan. } 18 \\
\text { Jan. } 18-30 \\
\text { Feb. } 14-28 \\
\text { Feb. } 28 \text { to Mar. } 16 \\
\text { Mar. } 16-29 \\
\text { May } 17-31 \\
\text { May } 31 \text { to June } 13 \\
\text { June } 13-29 \\
\text { June } 29 \text { to July } 11 \\
\text { July } 11-26\end{array}$ & $\begin{array}{r}5.0 \\
-\quad 1.6 \\
-\quad 1.0 \\
-\quad 5.4 \\
-\quad 0 \\
-\quad 1.8 \\
-\quad 4.1 \\
-\quad 9.5 \\
-\quad 10.4 \\
-\quad 3.2\end{array}$ & & $\begin{array}{l}\text { July } 26 \text { to Aug. } 8 \\
\text { Aug. } 8-21 \text { - } \\
\text { Aug. } 21 \text { to Sept. } 5 \\
\text { Sept. } 5-19-19 \\
\text { Sept. } 19 \text { to } 0 \text { ct. } 5 \\
\text { Oct. } 5-30 \text { - } \\
\text { Oct. } 30 \text { to Nov. } 19 \\
\text { Nov. } 19 \text { to Dec. } 4 \\
\text { Dec. } 4-28\end{array}$ & $\begin{array}{r}7.1 \\
10.9 \\
3.7 \\
1.2 \\
14.1 \\
6.1 \\
5.8 \\
2.1 \\
12.0\end{array}$ \\
\hline
\end{tabular}


Table 24. Daily rainfall, in inches, at continuous-record rain gage at LORAN station, Gagil Tamil

[Lat $9^{\circ} 32^{\prime} 52^{\prime \prime}$ N., long $138^{\circ} 10^{\prime} 09^{\prime \prime}$ E., in front of the LORAN station administration building; altitude, $70 \mathrm{ft}$ (from topographic map)]

\begin{tabular}{|c|c|c|c|c|c|c|c|c|c|c|c|c|c|}
\hline \multirow[b]{2}{*}{ Day } & \multirow{2}{*}{$\frac{1981}{\text { Dec. }}$} & \multicolumn{12}{|c|}{1982} \\
\hline & & Jan. & Feb. & Mar. & Apr. & May & June & July & Jg. & pt. & t. & v. & $\overline{e c}$ \\
\hline 1 & - & 0.41 & 0 & 0 & -- & 0.06 & 0.05 & $\star$ & 0.47 & 0.01 & 1.20 & 0.37 & 0.07 \\
\hline 2 & - & 0 & 0 & 0 & -- & .35 & 0 & $\star$ & 0 & .25 & .67 & 0 & .01 \\
\hline 3 & - & 0 & 0 & .01 & $-\infty$ & .01 & 0 & $\star$ & 0 & .20 & 0 & 0 & 0 \\
\hline 4 & $-\infty$ & 0 & .68 & .05 & $-\infty$ & 0 & .07 & $\star$ & 0 & 0 & .11 & 0 & 0 \\
\hline 5 & 0 & 0 & 1.69 & 0 & - & .01 & 0 & * & .07 & 1.14 & .29 & .01 & .62 \\
\hline 6 & .67 & 0 & 2.90 & .31 & - & .46 & 0 & $\star$ & 0 & & .48 & .05 & .79 \\
\hline 7 & .38 & 0 & .01 & $\star$ & - & .30 & .55 & 22.52 & .40 & .96 & 1.14 & 0 & .25 \\
\hline 8 & 0 & 0 & .65 & $\star$ & - & 0 & .05 & .47 & 0 & 0 & .68 & 1.14 & .49 \\
\hline 9 & .42 & .41 & .01 & $\star$ & -- & .36 & .08 & .04 & 0 & 0 & .72 & 0 & .55 \\
\hline 10 & .52 & .70 & 0 & $\star$ & 0.41 & 0 & 2.02 & .19 & .40 & 0 & .07 & .36 & .71 \\
\hline 11 & .07 & .16 & 0 & $\star$ & .01 & .22 & 0 & .48 & .04 & 0 & 0 & 0 & .86 \\
\hline 12 & .68 & 0 & 0 & $\star$ & 0 & .08 & 0 & .32 & .06 & 0 & .01 & 0 & .19 \\
\hline 13 & 0 & 0 & 0 & $\star$ & 0 & .05 & 0 & .02 & 0 & 2.54 & .48 & .49 & 1.13 \\
\hline 14 & .11 & 0 & 2.75 & $\star$ & 0 & .17 & 0 & 0 & .49 & 1.99 & 0 & .12 & 0 \\
\hline 15 & .06 & 0 & 0 & $\star$ & 0 & 1.54 & .02 & 4.69 & 1.09 & .17 & 0 & .25 & 0 \\
\hline 16 & .04 & 0 & 0 & .41 & .88 & 1.69 & 1.75 & 1.13 & 3.20 & 0 & 0 & .10 & 0 \\
\hline 17 & 0 & .17 & 0 & -- & 0 & .10 & .89 & 0 & .06 & 0 & .66 & 0 & 0 \\
\hline 18 & 0 & .08 & .10 & - & 0 & 1.50 & .06 & .40 & 0 & 0 & .64 & 0 & 0 \\
\hline 19 & .05 & 0 & .08 & - & 0 & 0 & .28 & .22 & 1.68 & 0 & .07 & 0 & 0 \\
\hline 20 & 0 & 0 & .32 & $-\infty$ & 0 & .10 & 7.08 & 1.20 & .62 & 0 & .38 & 0 & 0 \\
\hline 21 & .02 & 0 & 0 & - & .28 & .08 & $\star$ & 0 & 1.60 & 0 & .11 & 0 & 0 \\
\hline 22 & .07 & 0 & .01 & - & .01 & 0 & $\star$ & 0 & .55 & 0 & 0 & .84 & 0 \\
\hline 23 & 3.31 & .59 & .32 & -- & 0 & 0 & * & 1.37 & .07 & 0 & .65 & .04 & 0 \\
\hline 24 & .19 & 4.84 & .02 & -- & 0 & 0 & * & .10 & 0 & 0 & .25 & 0 & .60 \\
\hline 25 & .80 & 0 & .03 & -- & 0 & 0 & * & .40 & 0 & 1.67 & 0 & .11 & 0 \\
\hline 26 & .04 & 0 & 1.15 & $=$ & 0 & 0 & $\star$ & .11 & .82 & .08 & 0 & .02 & 0 \\
\hline 27 & 0 & 0 & 0 & -- & .36 & .28 & $\star$ & 0 & 1.45 & .05 & 0 & .01 & 0 \\
\hline 28 & 0 & 0 & 0 & - & 0 & .06 & $\star$ & 0 & .95 & .24 & 0 & .01 & 0 \\
\hline 29 & 0 & 0 & & -- & 0 & 0 & $\star$ & .06 & 1.31 & 0 & .06 & .26 & .02 \\
\hline 30 & 0 & 0 & & - & 0 & .08 & $\star$ & 0 & 1.54 & 1.31 & 0 & .82 & 0 \\
\hline 31 & 0 & 0 & & - & & .05 & & 0 & .12 & & .59 & & 0 \\
\hline Total & $(8.5)$ & 7.36 & 10.72 & $(7.0)$ & $(3.2)$ & 7.55 & $\star$ & $(46.62)$ & 16.99 & 11.09 & 9.26 & 5.00 & 6.29 \\
\hline
\end{tabular}

* Included in following total.

Recorded rainfall June $20(1300)$ to June 21 (0600): 15.48 inches (June 21, 0000-0600, 8.64 inches). Rainfall at Yap airport: June 21, 13.17 inches; June 21-30, 17.93 inches; July $1-7,3.13$ inches.

No rainfall record December 1-4, 1981 and March 17 to April 9, 1982. Rainfall estimated on basis of rainfall at Yap airport.

Total for 1982: 131.08 inches. 

Table 24. Daily rainfall, in inches, at continuous-record rain gage

1983

\begin{tabular}{|c|c|c|c|c|c|c|c|}
\hline Year & Jan. & Feb. & Mar. & Apr. & May & June & July \\
\hline 1 & 0.10 & 0 & 0 & 0 & 0 & 0 & 0.02 \\
\hline 2 & .01 & 0 & 0 & 0 & .05 & 0 & .29 \\
\hline 3 & 0 & 0 & .06 & 0 & 0 & 1.27 & 1.10 \\
\hline 4 & 0 & 0 & 0 & 0 & .02 & 0 & .84 \\
\hline 5 & 0 & 0 & 0 & .05 & .02 & 0 & .23 \\
\hline 6 & .05 & 0 & 0 & 0 & 0 & 0 & .11 \\
\hline 7 & 0 & 0 & 0 & .12 & 0 & 0 & .18 \\
\hline 8 & 0 & 0 & 0 & 0 & .02 & 0 & .20 \\
\hline 9 & 0 & 0 & 0 & 0 & .29 & 0 & \\
\hline 10 & 0 & 0 & 0 & 0 & 0 & .96 & \\
\hline 11 & 0 & .07 & 0 & 0 & 0 & .13 & \\
\hline 12 & 0 & .02 & 0 & 0 & 0 & 0 & \\
\hline 13 & 0 & 0 & 0 & 0 & 0 & 0 & \\
\hline 14 & 0 & 0 & 0 & .02 & 0 & .84 & \\
\hline 15 & 0 & 0 & 0 & .01 & 0 & .02 & \\
\hline 16 & .22 & 0 & .02 & .17 & 0 & .19 & \\
\hline 17 & .11 & 0 & 0 & .01 & 0 & 0 & \\
\hline 18 & .04 & 0 & 0 & .05 & 0 & .12 & \\
\hline 19 & 0 & 0 & 0 & 0 & 0 & .70 & \\
\hline 20 & 0 & 0 & 0 & 0 & .32 & $\star$ & \\
\hline 21 & 0 & 0 & 0 & 0 & 0 & $\hbar$ & \\
\hline 22 & 0 & 0 & 0 & 0 & 0 & \pm & \\
\hline 23 & 0 & 0 & 0 & 0 & 0 & $*$ & \\
\hline 24 & 0 & 0 & 0 & 0 & 0 & $\star$ & \\
\hline 25 & 0 & 0 & 0 & 0 & 1.20 & $\star$ & \\
\hline 26 & .17 & 0 & 0 & .02 & .31 & $\star$ & \\
\hline 27 & 0 & .10 & 0 & 0 & 0 & $\star$ & \\
\hline 28 & 0 & 0 & 0 & 0 & 0 & 2.83 & \\
\hline 29 & 0 & & 2.10 & 0 & .12 & .35 & \\
\hline 30 & 0 & & .06 & 0 & .70 & .52 & \\
\hline 31 & 0 & & 0 & & 0 & & \\
\hline Total & 0.70 & 0.19 & 2.24 & 0.45 & 3.05 & 7.93 & \\
\hline
\end{tabular}


Evaporation

Table 25. Monthly and annual evaporation data for Guam and Yap

[Source: U.S. National Oceanic and Atmospheric Administration, 1956-72, 1973-82]

Year Jan. Feb. Mar. Apr. May June July Aug. Sept. Oct. Nov. Dec. Annual

Evaporation data for Guam (in inches)

(January 1956 to May 1958 at Fena Lake, August 1958 to present at Weather Service station)

\begin{tabular}{|c|c|c|c|c|c|c|c|c|c|c|c|c|c|}
\hline $\begin{array}{l}1956 \\
1957 \\
1958\end{array}$ & $\begin{array}{l}6.83 \\
6.18 \\
7.48\end{array}$ & $\begin{array}{l}6.54 \\
5.99 \\
6.08\end{array}$ & $\begin{array}{l}8.24 \\
7.32 \\
7.65\end{array}$ & $\begin{array}{l}9.13 \\
8.42 \\
9.34\end{array}$ & $\begin{array}{l}8.82 \\
8.71 \\
9.49\end{array}$ & $\begin{array}{c}7.81 \\
9.10 \\
--\end{array}$ & $\begin{array}{c}5.74 \\
7.41 \\
--\end{array}$ & $\begin{array}{l}5.86 \\
7.76\end{array}$ & $\begin{array}{l}4.49 \\
6.52\end{array}$ & $\begin{array}{l}5.01 \\
5.57\end{array}$ & $\begin{array}{l}5.26 \\
7.28\end{array}$ & $\begin{array}{l}5.92 \\
7.22\end{array}$ & $\begin{array}{c}79.65 \\
87.48 \\
--\end{array}$ \\
\hline $\begin{array}{l}1959 \\
1960 \\
1961 \\
1962 \\
1963 \\
1964 \\
1965 \\
1966 \\
1967 \\
1968 \\
1969 \\
1970 \\
1971 \\
1972 \\
1973 \\
1974 \\
1975 \\
1976 \\
1977 \\
1978 \\
1979 \\
1980 \\
1981\end{array}$ & $\begin{array}{l}5.63 \\
4.86 \\
4.27 \\
6.15 \\
4.73 \\
5.91 \\
5.35 \\
7.07 \\
5.18 \\
5.89 \\
5.57 \\
4.68 \\
4.61 \\
6.55 \\
5.94 \\
5.81 \\
6.13 \\
6.27 \\
6.64 \\
7.30 \\
7.26 \\
7.73 \\
5.54 \\
-.\end{array}$ & $\begin{array}{l}6.66 \\
6.26 \\
5.73 \\
4.94 \\
4.31 \\
6.39 \\
6.31 \\
6.55 \\
5.32 \\
6.31 \\
-.0 \\
5.90 \\
6.21 \\
6.65 \\
5.46 \\
6.62 \\
6.80 \\
5.58 \\
6.49 \\
6.10 \\
6.68 \\
6.43 \\
7.22 \\
6.20\end{array}$ & $\begin{array}{l}7.60 \\
7.05 \\
6.27 \\
7.81 \\
6.44 \\
7.01 \\
8.58 \\
7.78 \\
5.32 \\
8.50 \\
8.46 \\
7.93 \\
6.41 \\
5.75 \\
7.47 \\
6.90 \\
8.08 \\
7.22 \\
8.20 \\
9.46 \\
7.76 \\
7.85 \\
8.94 \\
7.64\end{array}$ & $\begin{array}{l}7.58 \\
8.05 \\
7.00 \\
6.17 \\
6.57 \\
6.99 \\
-.-17 \\
9.17 \\
6.07 \\
7.57 \\
8.96 \\
8.98 \\
6.65 \\
7.85 \\
8.46 \\
8.27 \\
8.35 \\
7.62 \\
9.03 \\
7.72 \\
9.50 \\
7.93 \\
8.13 \\
8.28\end{array}$ & $\begin{array}{r}9.03 \\
7.17 \\
6.87 \\
7.00 \\
6.21 \\
6.76 \\
-- \\
8.88 \\
7.00 \\
7.58 \\
8.04 \\
8.06 \\
8.77 \\
8.06 \\
8.14 \\
7.21 \\
9.01 \\
7.37 \\
8.48 \\
8.85 \\
10.33 \\
8.05 \\
6.80 \\
8.06\end{array}$ & $\begin{array}{l}7.96 \\
6.54 \\
5.57 \\
5.20 \\
5.37 \\
7.47 \\
-- \\
7.37 \\
5.43 \\
5.89 \\
8.06 \\
7.30 \\
6.03 \\
7.26 \\
6.49 \\
5.88 \\
9.29 \\
7.65 \\
7.89 \\
6.55 \\
8.44 \\
6.91 \\
7.14 \\
6.90\end{array}$ & $\begin{array}{l}6.98 \\
5.41 \\
5.08 \\
4.99 \\
5.09 \\
6.18 \\
7.35 \\
7.21 \\
5.06 \\
5.77 \\
5.74 \\
6.27 \\
5.38 \\
5.66 \\
5.46 \\
-.- \\
6.18 \\
6.59 \\
7.83 \\
5.90 \\
6.44 \\
6.33 \\
6.78 \\
5.89\end{array}$ & $\begin{array}{l}5.48 \\
5.31 \\
4.71 \\
4.67 \\
4.91 \\
5.82 \\
4.75 \\
6.75 \\
4.71 \\
4.71 \\
4.95 \\
5.67 \\
4.28 \\
5.91 \\
5.00 \\
4.79 \\
5.09 \\
5.69 \\
6.33 \\
6.99 \\
6.10 \\
6.34 \\
4.84\end{array}$ & $\begin{array}{l}5.61 \\
4.52 \\
4.38 \\
4.44 \\
4.28 \\
4.29 \\
4.58 \\
4.59 \\
4.76 \\
4.64 \\
4.49 \\
4.90 \\
4.86 \\
5.78 \\
5.87 \\
5.64 \\
5.61 \\
6.14 \\
5.47 \\
5.24 \\
5.33 \\
5.26 \\
5.14\end{array}$ & $\begin{array}{l}6.08 \\
5.12 \\
4.30 \\
4.63 \\
5.00 \\
5.26 \\
4.73 \\
5.56 \\
5.36 \\
4.60 \\
5.53 \\
4.55 \\
4.62 \\
5.74 \\
5.55 \\
5.33 \\
6.28 \\
5.70 \\
7.36 \\
5.53 \\
6.32 \\
5.16 \\
5.98 \\
7.01 \\
5.27\end{array}$ & $\begin{array}{l}4.64 \\
4.59 \\
5.03 \\
5.07 \\
4.45 \\
5.11 \\
5.95 \\
5.81 \\
5.39 \\
5.72 \\
4.32\end{array}$ & $\begin{array}{l}5.30 \\
4.89 \\
5.16 \\
4.96 \\
5.26 \\
-. \\
6.50 \\
5.88 \\
5.92 \\
5.67 \\
5.35 \\
5.78 \\
6.02 \\
7.31 \\
5.67 \\
5.29 \\
6.93 \\
6.39 \\
6.56 \\
6.90 \\
5.95 \\
6.36 \\
6.20 \\
5.15 \\
6.31\end{array}$ & $\begin{array}{c}-- \\
75.87 \\
68.92 \\
64.56 \\
66.16 \\
-- \\
73.22 \\
-- \\
80.17 \\
64.72 \\
72.15 \\
-- \\
74.70 \\
74.39 \\
74.58 \\
74.73 \\
-.- \\
84.49 \\
80.45 \\
85.49 \\
81.04 \\
85.46 \\
80.49 \\
83.30 \\
--\end{array}$ \\
\hline $\tan$ & 5.98 & 6.14 & 7.87 & 7.99 & 8.03 & 7.02 & 6.11 & 5.56 & 5.22 & 5.45 & 5.65 & 5.96 & 76.76 \\
\hline \multicolumn{14}{|c|}{ Evaporation data for Yap (in inches) } \\
\hline $\begin{array}{l}1978 \\
1979 \\
1980 \\
1981 \\
1982\end{array}$ & $\begin{array}{l}-- \\
6.52 \\
5.41 \\
3.99 \\
6.58\end{array}$ & $\begin{array}{l}-- \\
6.74 \\
6.16 \\
5.56 \\
5.60\end{array}$ & $\begin{array}{l}-- \\
7.49 \\
6.96 \\
7.48 \\
7.12\end{array}$ & $\begin{array}{l}-- \\
8.21 \\
6.87 \\
7.69 \\
7.56\end{array}$ & $\begin{array}{l}-. \\
7.41 \\
6.32 \\
8.41 \\
5.58\end{array}$ & $\begin{array}{c}-- \\
5.90 \\
5.97 \\
4.36 \\
5.70\end{array}$ & $\begin{array}{l}5.58 \\
5.55 \\
6.25 \\
5.31 \\
6.82\end{array}$ & $\begin{array}{l}6.70 \\
6.33 \\
5.96 \\
6.65 \\
7.75\end{array}$ & $\begin{array}{l}5.15 \\
6.15 \\
4.78 \\
7.01 \\
5.70\end{array}$ & $\begin{array}{l}5.33 \\
8.60 \\
6.54 \\
5.56\end{array}$ & $\begin{array}{l}5.06 \\
6.11 \\
5.24 \\
4.91 \\
5.76\end{array}$ & $\begin{array}{l}7.23 \\
6.11 \\
5.55 \\
5.35 \\
6.37\end{array}$ & $\begin{array}{c}-- \\
81.12 \\
72.01 \\
72.28 \\
76.42\end{array}$ \\
\hline ted & 5.62 & 6.02 & 7.26 & 7.58 & 6.93 & 5.48 & 5.90 & 6.68 & 5.76 & 6.38 & 5.42 & 6.12 & 75.46 \\
\hline
\end{tabular}

Totals of monthly means: Guam 76.98 , Yap 75.15 inches. 
Air Temperatures

Table 26. Monthly and annual mean air temperatures for Yap (1921-50)

Sources: "World Weather Records," publication of Smithsonian Institution,

$1934(1921-30)$, and $1947(1931-40)$.

U.S. Weather Bureau, $1959(1941-50)$.

Temperature in ${ }^{\circ} \mathrm{C}$

\begin{tabular}{|c|c|c|c|c|c|c|c|c|c|c|c|c|c|}
\hline Year & Jan. & Feb. & Mar. & Apr. & May & June & July & Aug. & Sept. & oct. & Nov. & Dec. & Annual \\
\hline $\begin{array}{l}1921 \\
1922 \\
1923 \\
1924 \\
1925 \\
1926 \\
1927 \\
1928 \\
1929 \\
1930 \\
1931 \\
1932 \\
1933 \\
1934 \\
1935 \\
1936 \\
1937 \\
1938 \\
1939 \\
1940 \\
1941 \\
1942 \\
1943 \\
1948 \\
1949 \\
1950\end{array}$ & $\begin{array}{c}-- \\
26.4 \\
26.5 \\
26.2 \\
27.0 \\
26.4 \\
26.9 \\
26.9 \\
26.1 \\
26.8 \\
26.4 \\
27.0 \\
26.6 \\
27.2 \\
26.4 \\
26.6 \\
26.7 \\
26.9 \\
26.6 \\
26.9 \\
26.5 \\
26.5 \\
26.5 \\
-- \\
26.7 \\
27.8\end{array}$ & $\begin{array}{c}-- \\
26.7 \\
26.3 \\
26.5 \\
26.9 \\
26.6 \\
26.6 \\
27.0 \\
26.0 \\
26.5 \\
26.0 \\
26.2 \\
26.5 \\
26.7 \\
26.8 \\
26.6 \\
26.6 \\
26.7 \\
26.7 \\
26.3 \\
26.4 \\
26.9 \\
26.7 \\
-. \\
27.1 \\
27.7\end{array}$ & $\begin{array}{c}-- \\
26.9 \\
26.7 \\
26.8 \\
27.2 \\
26.9 \\
27.3 \\
27.3 \\
26.6 \\
27.4 \\
26.6 \\
26.5 \\
26.9 \\
27.0 \\
27.0 \\
26.9 \\
26.7 \\
26.9 \\
26.9 \\
27.0 \\
26.9 \\
27.2 \\
26.7 \\
-- \\
27.6 \\
27.8\end{array}$ & $\begin{array}{r}-. \\
27.4 \\
27.3 \\
27.2 \\
27.3 \\
27.8 \\
27.4 \\
27.6 \\
26.8 \\
27.6 \\
27.5 \\
27.0 \\
27.3 \\
27.2 \\
27.3 \\
27.2 \\
27.2 \\
27.2 \\
27.4 \\
27.0 \\
27.6 \\
27.3 \\
27.0 \\
-. \\
28.3 \\
28.3\end{array}$ & $\begin{array}{c}-- \\
27.4 \\
27.0 \\
27.2 \\
27.2 \\
28.3 \\
27.4 \\
27.4 \\
27.0 \\
27.8 \\
27.9 \\
27.0 \\
27.4 \\
27.5 \\
27.5 \\
27.0 \\
27.5 \\
27.0 \\
27.3 \\
27.7 \\
27.6 \\
27.4 \\
27.2 \\
-- \\
28.1 \\
28.2\end{array}$ & $\begin{array}{c}- \\
27.1 \\
26.7 \\
27.2 \\
27.4 \\
27.8 \\
27.3 \\
27.1 \\
27.5 \\
27.7 \\
27.9 \\
27.2 \\
27.3 \\
27.3 \\
27.6 \\
27.4 \\
27.2 \\
27.0 \\
27.8 \\
27.5 \\
27.2 \\
27.6 \\
26.8 \\
-. \\
27.7 \\
27.8\end{array}$ & $\begin{array}{r}27.0 \\
26.5 \\
26.4 \\
26.7 \\
26.5 \\
27.1 \\
27.0 \\
27.1 \\
26.4 \\
27.4 \\
27.6 \\
26.8 \\
26.8 \\
26.9 \\
26.9 \\
26.8 \\
27.1 \\
27.1 \\
26.8 \\
26.8 \\
26.7 \\
26.3 \\
26.8 \\
. . \\
28.0 \\
27.7\end{array}$ & $\begin{array}{c}26.8 \\
26.4 \\
26.0 \\
27.0 \\
26.6 \\
26.6 \\
26.4 \\
27.3 \\
26.5 \\
27.8 \\
27.0 \\
27.0 \\
27.1 \\
26.9 \\
27.3 \\
26.8 \\
26.9 \\
27.2 \\
27.1 \\
26.7 \\
26.4 \\
26.5 \\
26.6 \\
-. \\
27.4 \\
27.9\end{array}$ & $\begin{array}{l}26.7 \\
26.7 \\
26.8 \\
26.9 \\
27.1 \\
26.7 \\
-. \\
26.6 \\
26.6 \\
27.9 \\
27.0 \\
26.6 \\
27.0 \\
27.1 \\
26.9 \\
27.0 \\
26.9 \\
26.7 \\
26.8 \\
26.9 \\
27.0 \\
26.7 \\
27.0 \\
27.4 \\
27.4 \\
27.6\end{array}$ & $\begin{array}{l}27.0 \\
27.2 \\
27.0 \\
26.7 \\
26.6 \\
27.0 \\
-- \\
27.0 \\
26.9 \\
28.6 \\
26.8 \\
27.5 \\
26.5 \\
27.2 \\
27.1 \\
27.1 \\
27.0 \\
26.9 \\
27.1 \\
27.3 \\
27.2 \\
26.9 \\
27.0 \\
27.1 \\
27.6 \\
27.6\end{array}$ & $\begin{array}{l}26.9 \\
27.0 \\
26.8 \\
26.7 \\
27.0 \\
27.2 \\
27.2 \\
27.0 \\
26.8 \\
28.1 \\
26.8 \\
27.2 \\
26.8 \\
26.8 \\
27.1 \\
27.4 \\
27.2 \\
27.0 \\
27.0 \\
27.2 \\
27.3 \\
27.1 \\
26.9 \\
27.2 \\
28.3 \\
27.7\end{array}$ & $\begin{array}{c}26.6 \\
27.0 \\
26.9 \\
26.8 \\
-.- \\
27.3 \\
27.2 \\
27.0 \\
26.6 \\
27.0 \\
27.1 \\
26.8 \\
26.9 \\
26.9 \\
26.9 \\
27.2 \\
27.3 \\
26.5 \\
27.1 \\
26.9 \\
26.8 \\
26.9 \\
27.0 \\
26.8 \\
27.9 \\
27.3\end{array}$ & $\begin{array}{c}-- \\
26.9 \\
26.7 \\
26.8 \\
-- \\
27.1 \\
-- \\
27.1 \\
26.6 \\
27.5 \\
27.1 \\
26.9 \\
26.9 \\
27.1 \\
27.1 \\
27.0 \\
27.0 \\
26.9 \\
27.0 \\
27.0 \\
27.0 \\
26.9 \\
26.9 \\
-- \\
27.7 \\
27.8\end{array}$ \\
\hline
\end{tabular}


Table 27. Monthly and annual mean air temperatures for Yap (1951-81)

Source: U.S. National Oceanic and Atmospheric Administration, 1981.

Temperatures converted from ${ }^{\circ} \mathrm{F}$ to ${ }^{\circ} \mathrm{C}$

\begin{tabular}{|c|c|c|c|c|c|c|c|c|c|c|c|c|c|}
\hline Year & Jan. & Feb. & Mar. & Apr. & May & June & July & Aug. & Sept. & oct. & Nov. & Dec. & Annual \\
\hline $\begin{array}{l}1951 \\
1952 \\
1953 \\
1954 \\
1955 \\
1956 \\
1957 \\
1958 \\
1959 \\
1960 \\
1961 \\
1962 \\
1963 \\
1964 \\
1965 \\
1966 \\
1967 \\
1968 \\
1969 \\
1970 \\
1971 \\
1972 \\
1973 \\
1974 \\
1975 \\
1976 \\
1977 \\
1978 \\
1979 \\
1980 \\
1981\end{array}$ & $\begin{array}{l}27.3 \\
26.9 \\
27.4 \\
27.2 \\
26.5 \\
26.8 \\
26.8 \\
26 \\
26.8 \\
27.4 \\
27.4 \\
27.0 \\
27.1 \\
26.8 \\
26.9 \\
27.3 \\
27 \\
26.4 \\
26.6 \\
26.6 \\
26.7 \\
27.1 \\
26.8 \\
26 \\
26.8 \\
26.5 \\
26.3 \\
26.3 \\
26.7 \\
26.2 \\
26.7 \\
26.8 \\
\end{array}$ & 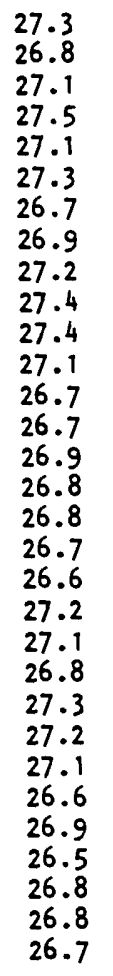 & 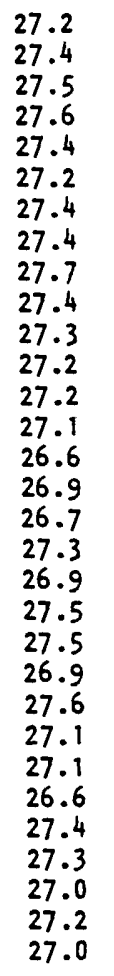 & $\begin{array}{l}28.0 \\
28.2 \\
27.7 \\
28.4 \\
27.9 \\
27.3 \\
\mid \\
27.7 \\
27.7 \\
27.8 \\
\mid \\
27.8 \\
27.8 \\
\mid\end{array}$ & 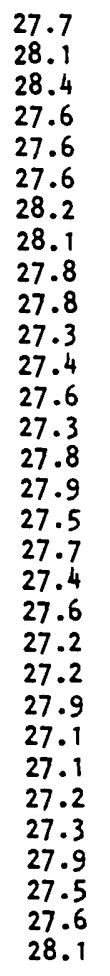 & $\begin{array}{l}27.9 \\
27.4 \\
27.6 \\
27.8 \\
27.6 \\
27.7 \\
27 \\
\mid\end{array}$ & $\begin{array}{l}27.6 \\
28.1 \\
28.1 \\
27.8 \\
27.6 \\
27.7 \\
27.3 \\
27.3 \\
27.3 \\
27.2 \\
27.7 \\
26.7 \\
\mid \\
27.1 \\
\\
27.2 \\
27.4 \\
26.1 \\
\end{array}$ & 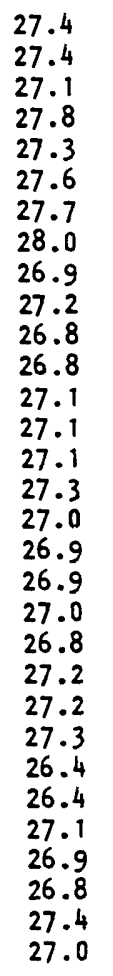 & $\begin{array}{l}28.0 \\
27.4 \\
27.8 \\
27.7 \\
27.8 \\
27.4 \\
27.8 \\
27 \\
27.4 \\
\mid \\
27.2 \\
27.6 \\
\end{array}$ & 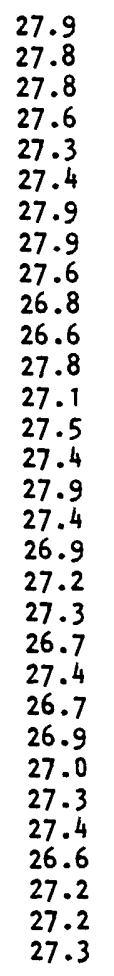 & $\begin{array}{l}28.1 \\
28.0 \\
27.3 \\
27.4 \\
27.6 \\
27.4 \\
28.1 \\
27.4 \\
27.9 \\
27.7 \\
26.7 \\
27.6 \\
\mid \\
27.5 \\
27.6 \\
27.2 \\
27.6 \\
\\
27.2 \\
27.3 \\
27.1 \\
\end{array}$ & 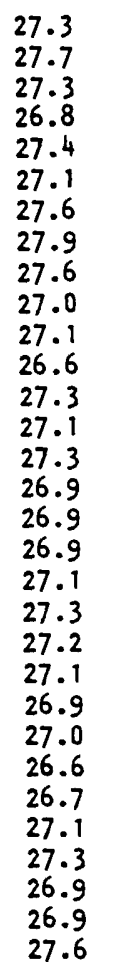 & $\begin{array}{l}27.6 \\
27.6 \\
27.6 \\
27.6 \\
27.4 \\
27.4 \\
27.6 \\
27.6 \\
27.5 \\
27.4 \\
27.1 \\
27.2 \\
27.3 \\
27.2 \\
27.1 \\
27.3 \\
27.1 \\
27.1 \\
27.1 \\
27.4 \\
27.0 \\
27.2 \\
27.3 \\
27.0 \\
26.8 \\
26.7 \\
27.2 \\
27.1 \\
27.2 \\
27.2 \\
27.2\end{array}$ \\
\hline $\begin{array}{c}1922-81= \\
\text { Mean }\end{array}$ & 26.9 & 27.0 & 27.3 & 27.7 & 27.7 & 27.4 & 27.3 & 27.2 & 27.3 & 27.3 & 27.4 & 27.2 & 27.3 \\
\hline $\begin{array}{l}\text { Maximum } \\
\text { Year }\end{array}$ & $\begin{array}{l}27.8 \\
1950\end{array}$ & $\begin{array}{l}27.7 \\
1950\end{array}$ & $\begin{array}{l}27.8 \\
1950\end{array}$ & $\begin{array}{l}28.4 \\
1954\end{array}$ & $\begin{array}{l}28.4 \\
1953\end{array}$ & $\begin{array}{l}28.4 \\
1957\end{array}$ & $\begin{array}{l}28.3 \\
1972\end{array}$ & $\begin{array}{l}28.0 \\
1958\end{array}$ & $\begin{array}{l}28.0 \\
1951\end{array}$ & $\begin{array}{l}28.6 \\
1930\end{array}$ & $\begin{array}{l}28.3 \\
1949\end{array}$ & $\begin{array}{l}27.9 \\
1949\end{array}$ & $\begin{array}{c}28.6 \\
10 / 1930\end{array}$ \\
\hline $\begin{array}{l}\text { Mininum } \\
\text { Year }\end{array}$ & $\begin{array}{l}26.1 \\
1929\end{array}$ & $\begin{array}{l}26.0 \\
1929 \\
1931\end{array}$ & $\begin{array}{l}26.5 \\
1932\end{array}$ & $\begin{array}{l}26.6 \\
1976\end{array}$ & $\begin{array}{l}27.0 \\
1923 \\
1929 \\
1932 \\
1936 \\
1938\end{array}$ & $\begin{array}{l}26.6 \\
1975\end{array}$ & $\begin{array}{l}26.1 \\
1965\end{array}$ & $\begin{array}{l}26.0 \\
1923\end{array}$ & $\begin{array}{l}26.4 \\
1976\end{array}$ & $\begin{array}{l}26.5 \\
1933\end{array}$ & $\begin{array}{l}26.7 \\
1924 \\
1961\end{array}$ & $\begin{array}{l}26.5 \\
1938\end{array}$ & $\begin{array}{c}26.0 \\
8 / 1923 \\
2 / 1929 \\
2 / 1931\end{array}$ \\
\hline
\end{tabular}




\section{Streamflow records}

\section{Gaging stations}

Table 28. Streamflow records of Qatliw Stream, Yap (16892000)

(Formerly published as Atelu Stream, Yap)

Location: Lat $9^{\circ} 32^{\prime} 58^{\prime \prime} \mathrm{N}$. , long $138^{\circ} 06^{\prime} 41^{\prime \prime} \mathrm{E} ., 90 \mathrm{ft}$ downstream from confluence with major tributary, $0.4 \mathrm{mi}$ northeast of Bael School and $0.5 \mathrm{mi}$ upstream from mouth.

Drainage area: $0.31 \mathrm{mi}^{2}$.

Period of record: 0ccasional low-flow measurements water years 1980-81.

Continuous record February to September 1982.

Gage: Water-stage recorder and concrete control. Altitude of gage is 35

ft (from topographic map).

Remarks: Records good. No diversion above station.

Extremes for period of record: Maximum discharge, $874 \mathrm{ft}^{3} / \mathrm{s}$ June 21,1982

(gage height, $5.96 \mathrm{ft}$ ), from rating curve extended above $9.9 \mathrm{ft}^{3} / \mathrm{s}$ on

basis of estimate of peak flow; no flow for several days.

A. Discharge measurements, in cubic feet per second

\begin{tabular}{|c|c|c|c|}
\hline \multicolumn{2}{|c|}{$\frac{0.2 \mathrm{mi} \text { upstream from mouth }}{\text { Date }}$ Discharge } & \multicolumn{2}{|c|}{$\begin{array}{l}\text { At gaging station, } \\
\frac{0.5 \mathrm{mi} \text { upstream from mouth }}{\text { Date }} \text { Discharge }\end{array}$} \\
\hline Sept. $20,1980 \ldots$ & 0.18 & July $21,1981 \ldots$ & 1.2 \\
\hline Oct. $21,1980 \ldots$ & 6.7 & Dec. $31,1981 \ldots$ & 1/. .01 \\
\hline Mar. 25, 1981 & 0 & Jan. 22, $1982 \ldots$ & $\underline{1 / .01}$ \\
\hline Apr. 8, $1981 \ldots$ & 0 & Feb. $12,1982 \ldots$ & .05 \\
\hline July $21,1981 \ldots$ & .90 & Mar. $25,1982 \ldots$ & .24 \\
\hline June 18,1982 & 3.2 & June $18,1982 \ldots$ & 2.7 \\
\hline July 14,1982 & .08 & July $14,1982 \ldots$ & .05 \\
\hline
\end{tabular}

1/ Estimated. 
Table 28. Streamflow records of Qatliw Stream, Yap---Continued B. Monthly discharges, in cubic feet per second

\begin{tabular}{|c|c|c|c|c|c|c|c|c|c|}
\hline Year & & Feb. & Mar. & Apr. & May & June & July & Aug. & Sept. \\
\hline \multirow[t]{2}{*}{1982} & Total & 48.20 & 15.42 & 0.59 & 13.67 & 230.98 & 50.42 & 69.71 & 45.19 \\
\hline & $\begin{array}{l}\text { Mean } \\
\text { Max. } \\
\text { Min. }\end{array}$ & $\begin{array}{c}1.72 \\
15 \\
.03\end{array}$ & $10^{.50}$ & $\begin{array}{l}.020 \\
.05 \\
0\end{array}$ & $\begin{array}{l}.44 \\
4.3 \\
0\end{array}$ & $\begin{array}{c}7.70 \\
106 \\
0\end{array}$ & $\begin{array}{l}1.63 \\
.02\end{array}$ & $\begin{array}{c}2.25 \\
15 \\
.02\end{array}$ & $\begin{array}{r}1.51 \\
14 \\
.01\end{array}$ \\
\hline
\end{tabular}

Peak discharges above base $\left(200 \mathrm{ft}^{3} / \mathrm{s}\right)$ : Feb. $6(0800) 385 \mathrm{ft}^{3} / \mathrm{s}(4.30 \mathrm{ft})$; June $21(0445) 874 \mathrm{ft}^{3} / \mathrm{s}(5.96 \mathrm{ft})$. 
Table 29. Streamflow records of Qaringeel Stream, Yap (16892400)

(Formerly published as Aringel Stream, Yap)

Location: Lat $9^{\circ} 31^{\prime} 02^{\prime \prime} \mathrm{N}$. , long $138^{\circ} 05^{\prime} 31^{\prime \prime} \mathrm{E}$., on right bank at Qaringeel and 0.3 mile southwest of Dalipeebinaew School.

Drainage area: $0.24 \mathrm{mi}^{2}$.

Period of record: April 1968 to September 1982.

Gage: Water-stage recorder and concrete control. Altitude of gage is

$15 \mathrm{ft}$ (from topographic map).

Remarks: Records fair. No diversion above station.

Average discharge: 14 years, $1.12 \mathrm{ft}^{3} / \mathrm{s}(811$ acre-ft/yr).

Extremes for period of record: Maximum discharge, $674 \mathrm{ft}^{3} / \mathrm{s}$ July 13 , 1981 (gage height, $7.82 \mathrm{ft}$ ), from rating curve extended above 20 $\mathrm{ft}^{3} / \mathrm{s}$; no flow for many days most years.

Discharge measurement made prior to beginning of continuous

discharge record

Oct. 9, $1967 \ldots .10 \mathrm{ft}^{3} / \mathrm{s}$ 
Table 29. Streamflow records of Qaringeel Stream, Yap--Cont inued A. Annual maximum discharge $(*)$ and peak discharges above base $\left(200 \mathrm{ft}^{3} / \mathrm{s}\right)$

\begin{tabular}{|c|c|c|c|c|c|c|c|}
\hline Date & Time & $\begin{array}{l}\text { Dis- } \\
\text { charge } \\
\left(f t^{3} / \mathrm{s}\right)\end{array}$ & $\begin{array}{c}\text { Gage } \\
\text { height } \\
(f t)\end{array}$ & Date & Time & $\begin{array}{l}\text { Dis- } \\
\text { charge } \\
\left(\mathrm{ft}^{3} / \mathrm{s}\right)\end{array}$ & $\begin{array}{c}\text { Gage } \\
\text { height } \\
(f t)\end{array}$ \\
\hline Sept. 22, 1968 & 0630 & $\star 210$ & 5.00 & $\begin{array}{l}\text { oct. } 9,1975 \\
\text { oct. } 17,1975\end{array}$ & $\begin{array}{l}+2300 \\
+1700\end{array}$ & $\begin{array}{r}222 \\
* 340\end{array}$ & $\begin{array}{l}a / 5.10 \\
a / 5.90\end{array}$ \\
\hline July 13, 1969 & 0030 & $* 376$ & 6.14 & May 12,1976 & 0700 & 295 & 5.60 \\
\hline July 23,1969 & 0500 & 313 & 5.72 & June 16, 1976 & 1330 & 292 & 5.58 \\
\hline July 29,1969 & 0630 & 208 & 4.98 & Aug. 6,1976 & 0730 & 241 & 5.24 \\
\hline $\begin{array}{l}\text { Aug. } 5,1969 \\
\text { Sept. } 10,1969\end{array}$ & $\begin{array}{l}0700 \\
0330\end{array}$ & $\begin{array}{l}325 \\
212\end{array}$ & $\begin{array}{l}5.80 \\
5.02\end{array}$ & Aug. 19, 1976 & 1300 & 266 & 5.41 \\
\hline & & & & Sept. 3, 1977 & 1030 & $* 195$ & 4.86 \\
\hline oct. 27,1969 & 1130 & 225 & 5.12 & & & & \\
\hline Aug. 15,1970 & 0800 & 271 & 5.44 & Aug. 19, 1978 & +1730 & 203 & $a / 4.94$ \\
\hline Aug. 21,1970 & 0130 & $* 408$ & 6.35 & Sept. 14,1978 & +0300 & $* 520$ & $\bar{a} / 7.05$ \\
\hline Aug. 26,1970 & 1830 & 265 & 5.40 & Sept. 17,1978 & +1230 & -- & -- \\
\hline Aug. 31,1970 & 1030 & 247 & 5.28 & & & & \\
\hline Sept. 19,1970 & 1630 & 250 & 5.30 & $\begin{array}{l}\text { June } 26,1979 \\
\text { Aug. } 17,1979\end{array}$ & $\begin{array}{l}1300 \\
0830\end{array}$ & $\begin{array}{r}242 \\
* 334\end{array}$ & $\begin{array}{l}5.25 \\
5.86\end{array}$ \\
\hline Oct. 14,1970 & 0200 & 306 & 5.67 & & & & \\
\hline Jan. 20,1971 & 2230 & 235 & 5.20 & 0ct. 1, 1979 & 2400 & 202 & 4.93 \\
\hline Apr. 24,1971 & 0500 & $\div 403$ & 6.32 & May 22,1980 & 1000 & 240 & 5.23 \\
\hline July 9, 1971 & 0030 & 203 & 4.94 & July 1,1980 & 0100 & 373 & 6.12 \\
\hline $\begin{array}{l}\text { Aug. } 6,1971 \\
\text { Sept. } 6,1971\end{array}$ & $\begin{array}{l}0800 \\
0600\end{array}$ & $\begin{array}{l}250 \\
262\end{array}$ & $\begin{array}{l}5.30 \\
5.38\end{array}$ & July 4,1980 & 0400 & $* 374$ & 6.13 \\
\hline & & & & Oct. 18,1980 & 1700 & 201 & 4.92 \\
\hline Mar. 6, 1972 & 1130 & $* 290$ & 5.57 & Dec. 2,1980 & 1800 & 277 & 5.48 \\
\hline Sept. 8, 1972 & 0200 & 207 & 4.95 & July 13,1981 & 2300 & $* 674$ & 7.82 \\
\hline Sept. 16, 1972 & 1430 & 204 & 4.93 & $\begin{array}{l}\text { July } 27,1981 \\
\text { Aug. } 5,1981\end{array}$ & $\begin{array}{l}0230 \\
1830\end{array}$ & $\begin{array}{l}355 \\
300\end{array}$ & $\begin{array}{l}6.00 \\
5.63\end{array}$ \\
\hline Sept. 15,1973 & +2200 & $* 457$ & $a / 6.68$ & & & & \\
\hline & & & & Dec. 23,1981 & 0700 & 358 & 6.02 \\
\hline June 6,1974 & 0100 & +210 & +5.0 & Feb. 6,1982 & 0800 & 260 & 5.37 \\
\hline June 20,1974 & 0100 & 202 & 4.93 & May 18,1982 & +1600 & 232 & $a / 5.18$ \\
\hline July 2, 1974 & 1700 & $\div 434$ & $a / 6.53$ & $\begin{array}{ll}\text { June } 21, & 1982 \\
\text { Aug. } 30, & 1982\end{array}$ & $\begin{array}{l}0500 \\
0530\end{array}$ & $\begin{array}{r}* 445 \\
304\end{array}$ & $\begin{array}{l}6.60 \\
5.66\end{array}$ \\
\hline $\begin{array}{ll}\text { Nov. } & 4,1974 \\
\text { Jan. } 21, & 1975\end{array}$ & $\begin{array}{l}0930 \\
0330\end{array}$ & $\begin{array}{r}* 277 \\
206\end{array}$ & $\begin{array}{l}5.48 \\
4.96\end{array}$ & & & & \\
\hline
\end{tabular}

+ About.

a/ From floodmark. 
Table 29. Streamflow records of Qaringeel Stream, Yap--Cont inued

B. Annual minimum discharge

\begin{tabular}{llclll}
\hline $\begin{array}{l}\text { Water } \\
\text { year }\end{array}$ & Date & $\begin{array}{c}\text { Discharge } \\
\left(\mathrm{ft}^{3} / \mathrm{s}\right)\end{array}$ & $\begin{array}{c}\text { Water } \\
\text { year }\end{array}$ & Date & $\begin{array}{c}\text { Discharge } \\
\left(\mathrm{ft}^{3} / \mathrm{s}\right)\end{array}$ \\
\hline 1968 a/ & Many days (46) & 0 & 1976 & Many days (56) & 0 \\
1969 & Many days (118) & 0 & 1977 & Many days (118) & 0 \\
1970 & Many days (63) & 0 & 1978 & Many days (122) & 0 \\
1971 & April 18, 19 & .01 & 1979 & Many days (97) & 0 \\
1972 & Many days (36) & 0 & 1980 & Many days (58) & 0 \\
1973 & Many days (135) & 0 & 1981 & Many days (61) & 0 \\
1974 & Many days (19) & 0 & 1982 & Many days (52) & 0 \\
1975 & Many days (76) & 0 & & &
\end{tabular}




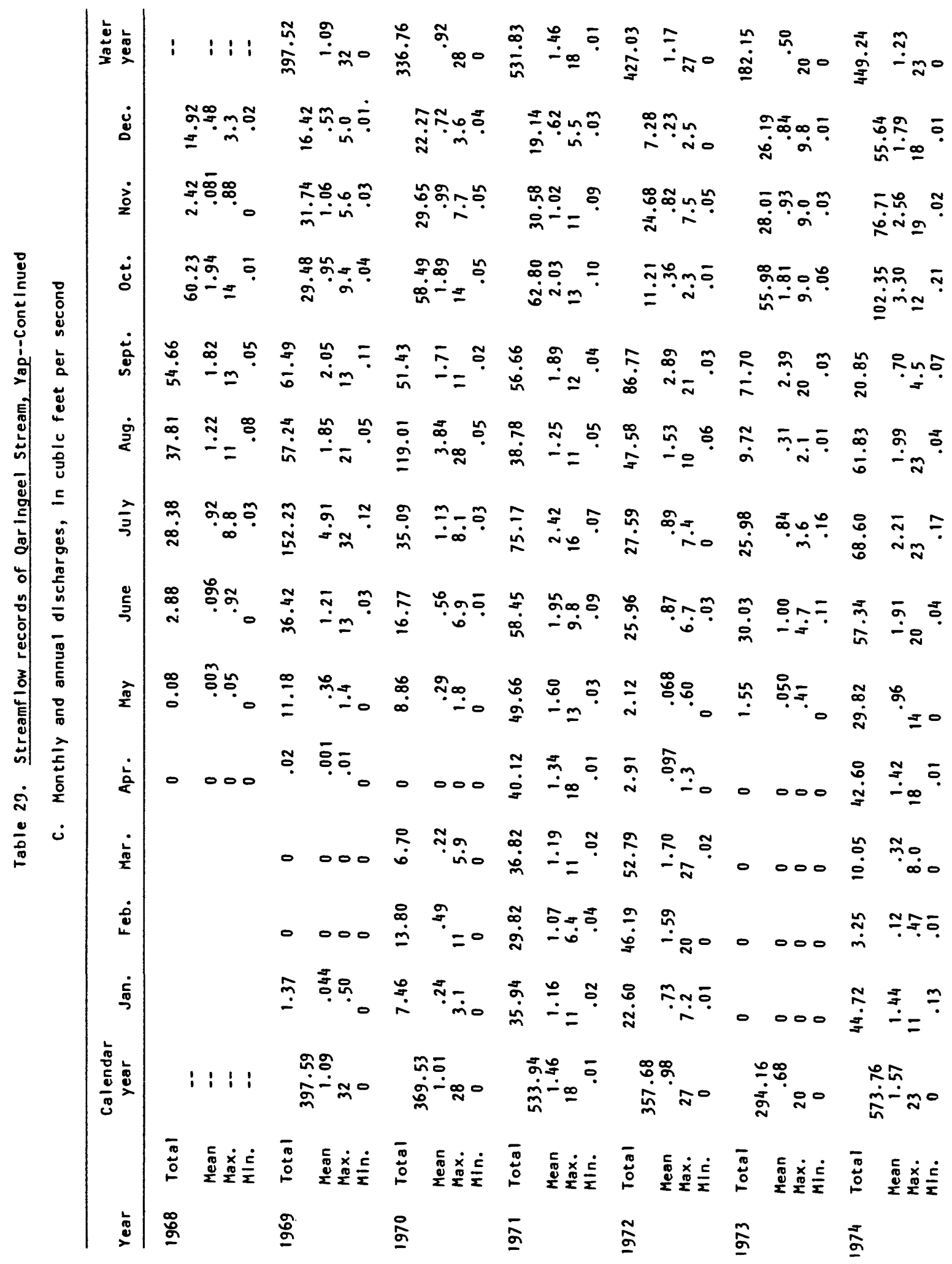




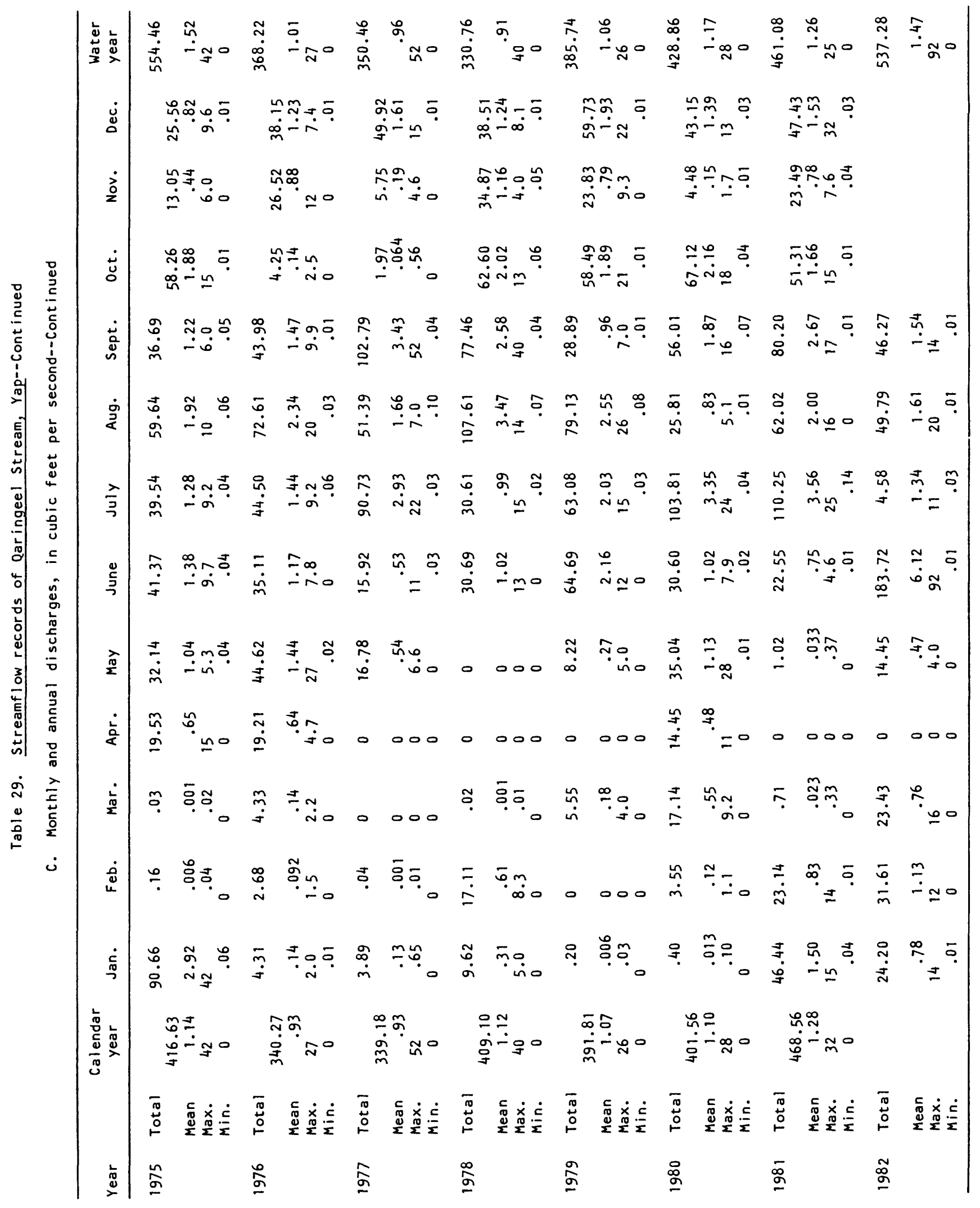


Table 30. Streamflow records of Daloelaeb Stream, Yap (16892800)

(Formerly published as Dalolab Stream, Yap)

Location: Lat $9^{\circ} 31^{\prime} 05^{\prime \prime} \mathrm{N}$. , long $138^{\circ} 06^{\prime} 21^{\prime \prime} \mathrm{E}$., on left bank $0.17 \mathrm{mi}$ north of Daloelaeb Hill water tank and $1.3 \mathrm{mi}$ northwest of Protestant Mission Church in Colonia.

Drainage area: $0.07 \mathrm{mi}^{2}$.

Period of record: April 1968 to December 1981 (discontinued).

Gage: Water-stage recorder and concrete control. Altitude of gage is $110 \mathrm{ft}$ from topographic map).

Remarks: Records good. No diversion above station.

Average discharge: 13 years, $0.366 \mathrm{ft}^{3} / \mathrm{s}$ ( 265 acre-ft/yr).

Extremes for period of record: Maximum discharge, $180 \mathrm{ft}^{3} / \mathrm{s}$ Sept. 15, 1973

(gage height, $4.80 \mathrm{ft}$, from floodmark in well), from rating curve extended above $17 \mathrm{ft}^{3} / \mathrm{s}$; no flow for many days each year.

Discharge measurement made after the end of continuous discharge record

Sept. 15,1982

$0.09 \mathrm{ft}^{3} / \mathrm{s}$ 
Table 30. Streamflow records of Daloelaeb Stream, Yap--Cont inued

A. Annual maximum discharge $(*)$ and peak discharges above base $\left(75 \mathrm{ft}^{3} / \mathrm{s}\right)$

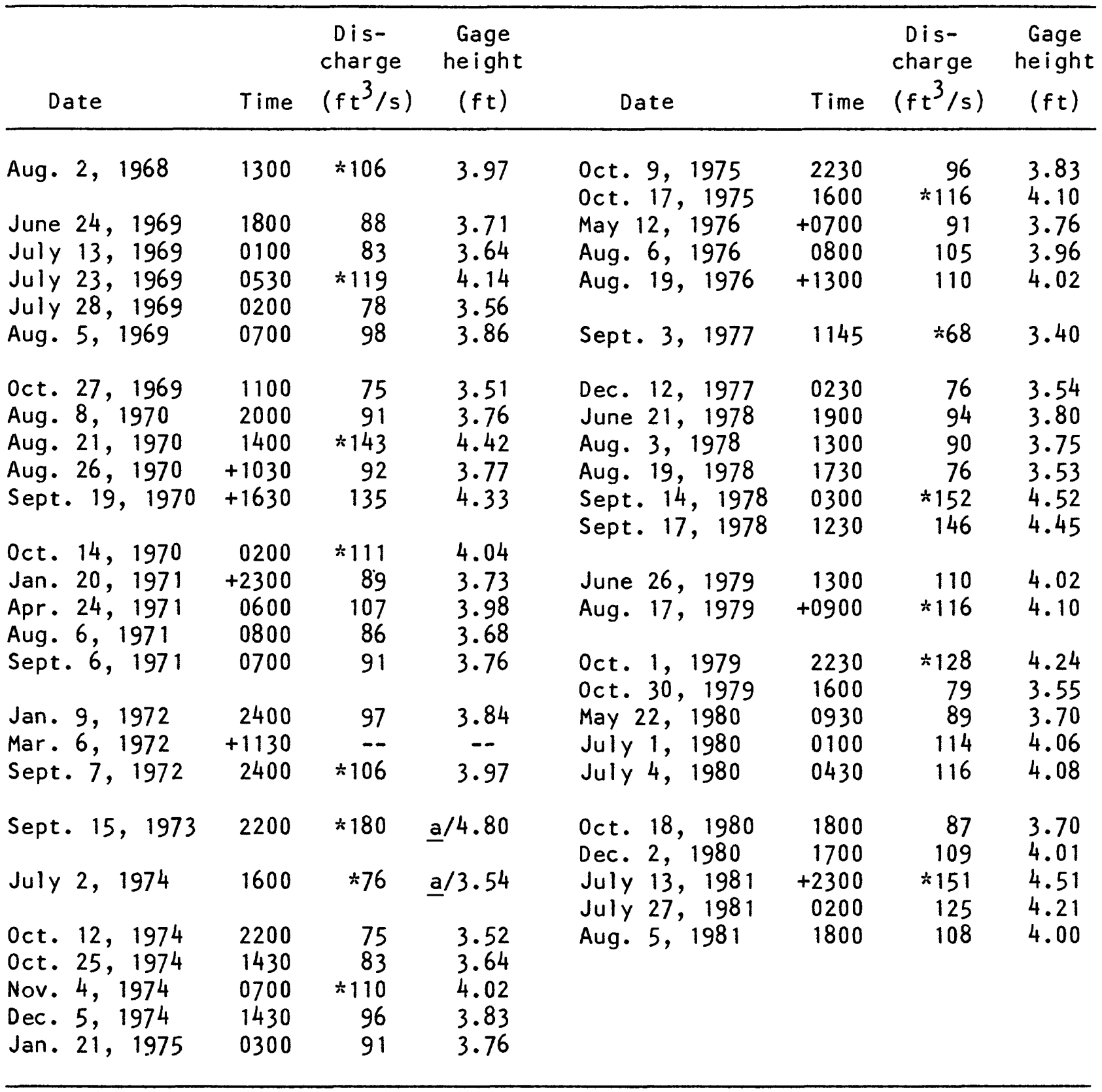

+ About.

a/ From floodmark. 
Table 30. Streamflow records of Daloelaeb Stream, Yap--Cont inued

B. Annual minimum discharge

\begin{tabular}{llclll}
\hline $\begin{array}{l}\text { Water } \\
\text { year }\end{array}$ & Date & $\begin{array}{c}\text { Discharge } \\
\left(\mathrm{ft}^{3} / \mathrm{s}\right)\end{array}$ & $\begin{array}{l}\text { Water } \\
\text { year }\end{array}$ & Date & $\begin{array}{c}\text { Discharge } \\
\left(\mathrm{ft}^{3} / \mathrm{s}\right)\end{array}$ \\
\hline $1968 \mathrm{a} /$ & Many days (94) & 0 & 1975 & Many days (108) & 0 \\
1969 & Many days (197) & 0 & 1976 & Many days (116) & 0 \\
1970 & Many days (136) & 0 & 1977 & Many days (163) & 0 \\
1971 & Many days (23) & 0 & 1978 & Many days (220) & 0 \\
1972 & Many days (73) & 0 & 1979 & Many days (147) & 0 \\
1973 & Many days (190) & 0 & 1980 & Many days (143) & 0 \\
1974 & Many days (74) & 0 & 1981 & Many days (135) & 0 \\
\hline
\end{tabular}

al April to September 1968. 


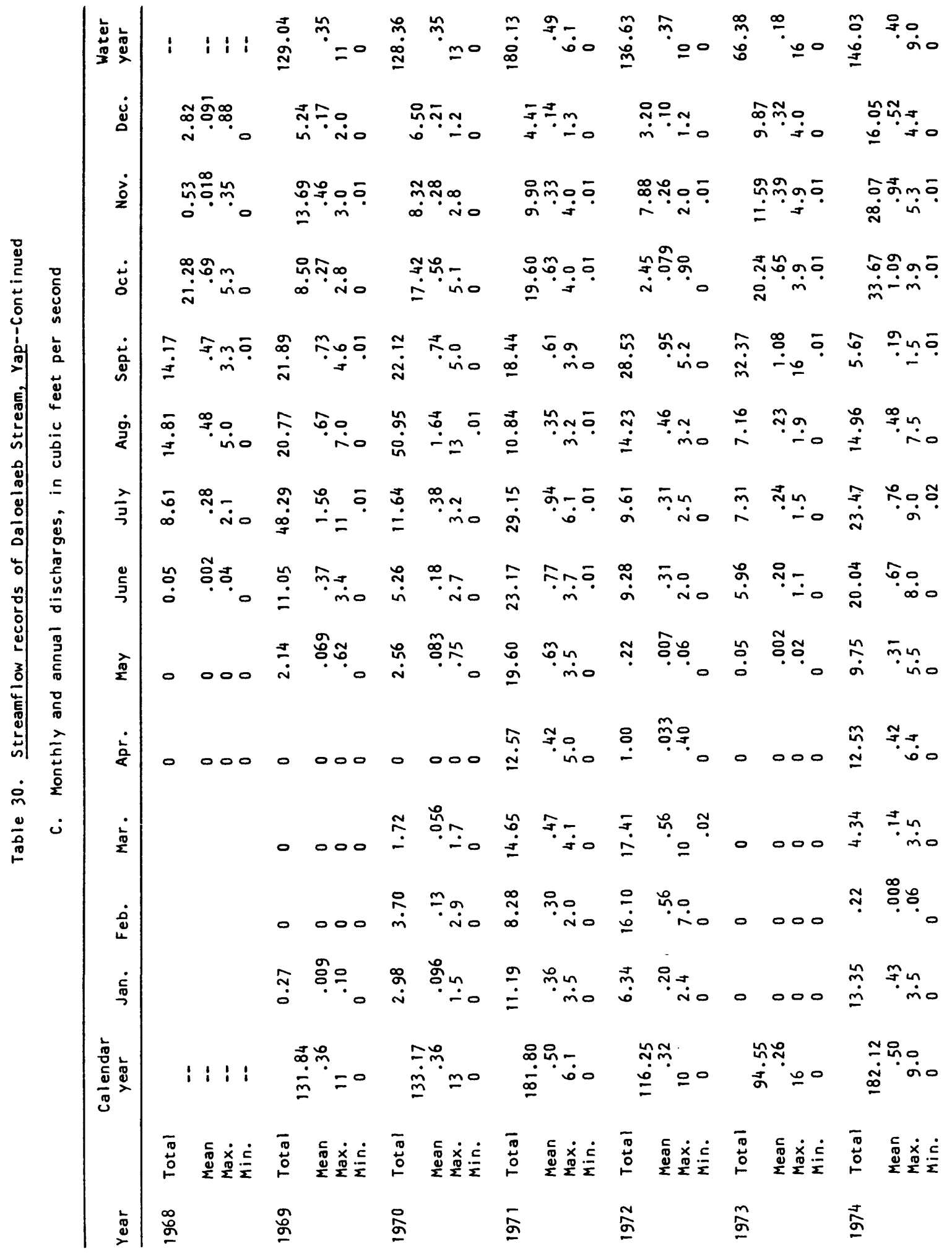




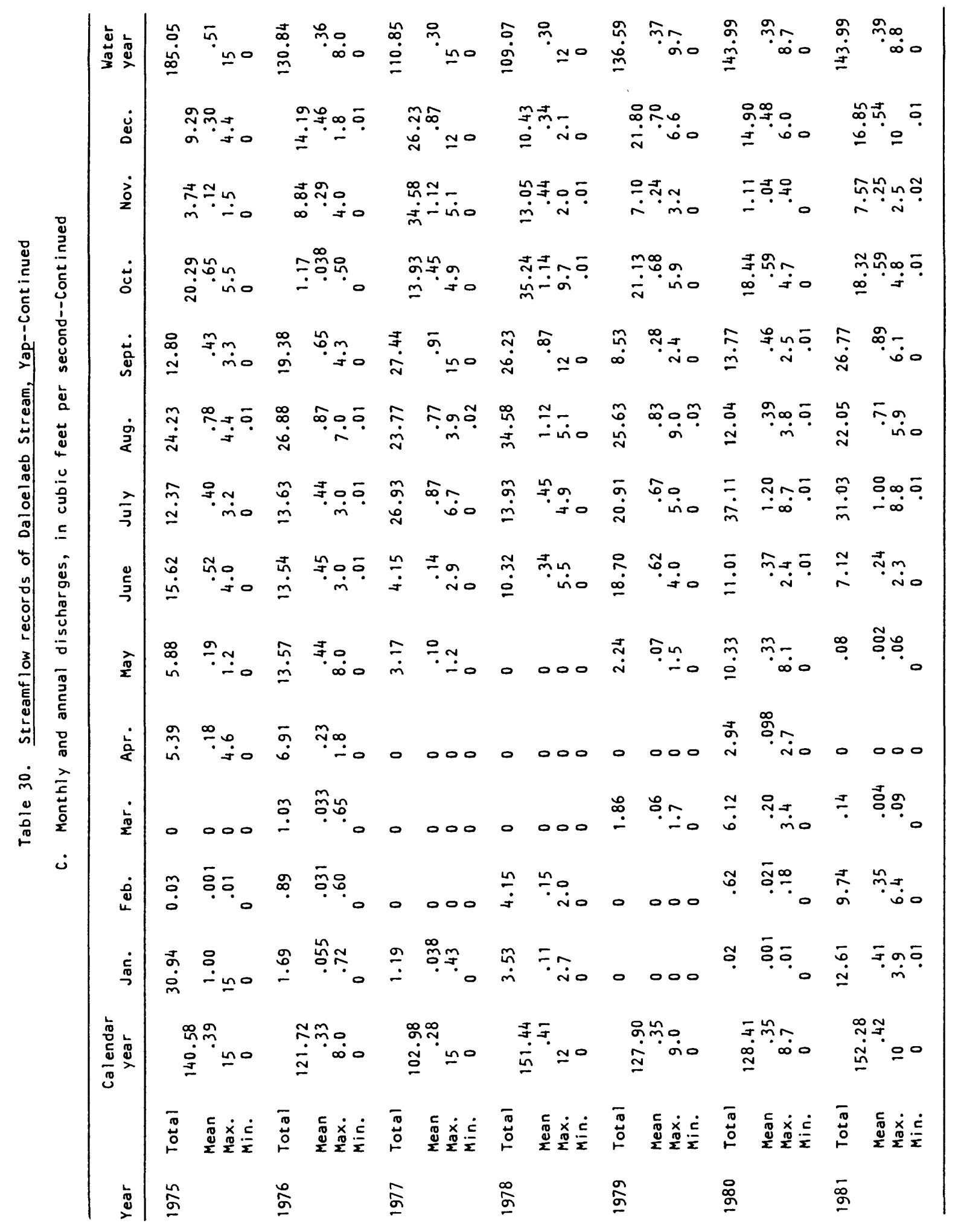


Table 31. Streamflow records of Peemgoy Stream, Yap (16892900)

(Formerly published as Pemgoy Stream, Yap)

Location: Lat $9^{\circ} 31^{\prime} 07^{\prime \prime} \mathrm{N}$. , long $138^{\circ} 06^{\prime} 36^{\prime \prime} \mathrm{E}$., on right bank at Taalgum, $100 \mathrm{ft}$ upstream from confluence with Taalgum Stream, $0.3 \mathrm{mi}$ southeast of

Mount Peemgoy, and $1.0 \mathrm{mi}$ northwest of Protestant Mission Church in Colonia. Drainage area: $0.14 \mathrm{mi}^{2}$.

Period of record: April 1968 to July 1982 (discontinued).

Gage: Water-stage recorder. Concrete control since Mar. 30, 1974. Altitude of gage is $60 \mathrm{ft}$ (from topographic map).

Remarks: Records fair. No diversion above station.

Average discharge: 13 years (water years 1969-81), $0.591 \mathrm{ft}^{3} / \mathrm{s}(428 \mathrm{acre}-\mathrm{ft} / \mathrm{yr})$. Extremes for period of record: Maximum discharge, $335 \mathrm{ft}^{3} / \mathrm{s}$ July 13, 1981

(gage height, $5.40 \mathrm{ft}$ ), from rating curve extended above $15 \mathrm{ft}^{3} / \mathrm{s}$; no flow for many days most years.

Discharge measurements, in cubic feet per second, made outside the

\section{period of continuous discharge record}

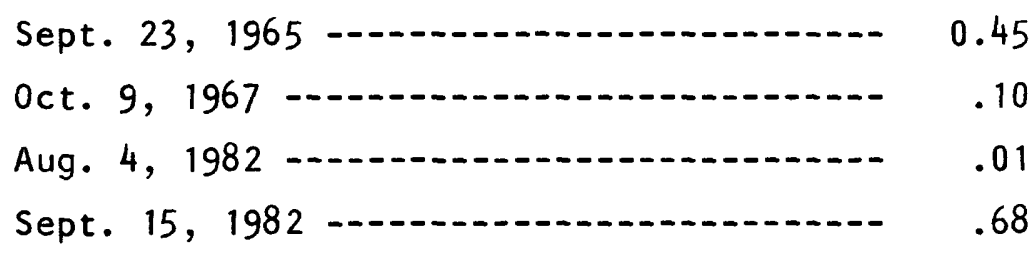


Table 31. Streamflow records of Peemgoy Stream, Yap--Continued

A. Annual maximum discharge $(*)$ and peak discharges above base $\left(70 \mathrm{ft}^{3} / \mathrm{s}\right)$

\begin{tabular}{|c|c|c|c|c|c|c|c|}
\hline Date & Time & $\begin{array}{l}\text { Dis- } \\
\text { charge } \\
\left(\mathrm{ft}^{3} / \mathrm{s}\right)\end{array}$ & $\begin{array}{l}\text { Gage } \\
\text { height } \\
(f t)\end{array}$ & Date & Time & $\begin{array}{l}\text { Dis- } \\
\text { charge } \\
\left(\mathrm{ft}^{3} / \mathrm{s}\right)\end{array}$ & $\begin{array}{l}\text { Gage } \\
\text { height } \\
(f t)\end{array}$ \\
\hline Aug. 2, 1968 & 1300 & $\star 66$ & 2.94 & Sept. 3, 1977 & +1100 & $\star 87$ & $\mathrm{a} / 3.24$ \\
\hline $\begin{array}{l}\text { July } 23,1969 \\
\text { Aug. } 5,1969\end{array}$ & $\begin{array}{l}0500 \\
0630\end{array}$ & $\begin{array}{r}* 161 \\
104\end{array}$ & $\begin{array}{l}4.06 \\
3.45\end{array}$ & $\begin{array}{l}\text { June } 21,1978 \\
\text { Aug. } 3,1978 \\
\text { Sept. } 14,1978\end{array}$ & $\begin{array}{l}1900 \\
1300 \\
0230\end{array}$ & $\begin{array}{r}75 \\
72 \\
* 314\end{array}$ & $\begin{array}{r}3.07 \\
3.03 \\
a / 5.26\end{array}$ \\
\hline Aug. 8, 1970 & 1930 & 79 & 3.13 & Sept. 17,1978 & 1230 & 192 & $\underline{a} / 4.34$ \\
\hline $\begin{array}{l}\text { Aug. } 15,1970 \\
\text { Aug. } 21,1970 \\
\text { Aug. } 26,1970\end{array}$ & $\begin{array}{r}0630 \\
+1300 \\
1800\end{array}$ & $\begin{array}{r}76 \\
198 \\
74\end{array}$ & $\begin{array}{r}3.08 \\
a / 4.39 \\
3.05\end{array}$ & $\begin{array}{ll}\text { June } 26, & 1979 \\
\text { Aug. } 17, & 1979\end{array}$ & $\begin{array}{l}1230 \\
0900\end{array}$ & $\begin{array}{r}86 \\
* 165\end{array}$ & $\begin{array}{l}3.22 \\
4.10\end{array}$ \\
\hline Sept. 19, 1970 & 1630 & $* 207$ & 4.47 & $\begin{array}{lll}\text { Oct. } & 1,1979 \\
\text { Oct. } & 30,1979\end{array}$ & $\begin{array}{l}2300 \\
1500\end{array}$ & $\begin{array}{r}\div 234 \\
90\end{array}$ & $\begin{array}{l}4.68 \\
3.28\end{array}$ \\
\hline $\begin{array}{l}\text { Oct. 14, } 1970 \\
\text { Jan. 20, } 1971 \\
\text { Sept. 6, } 1971\end{array}$ & $\begin{array}{l}0200 \\
2230 \\
0600\end{array}$ & $\begin{array}{r}86 \\
71 \\
* 90\end{array}$ & $\begin{array}{l}3.22 \\
3.02 \\
3.23\end{array}$ & $\begin{array}{ll}\text { May } 22, & 1980 \\
\text { July } 1, & 1980 \\
\text { July } 4, & 1980\end{array}$ & $\begin{array}{r}0830 \\
+0100 \\
+0400\end{array}$ & $\begin{array}{r}88 \\
+150 \\
179\end{array}$ & $\begin{array}{l}3.25 \\
-- \\
4.22\end{array}$ \\
\hline $\begin{array}{l}\text { Oct. } 3,1971 \\
\text { Mar. 6, } 1972 \\
\text { June } 25,1972 \\
\text { Sept. } 8,1972\end{array}$ & $\begin{array}{r}+0030 \\
1100 \\
0130 \\
0030\end{array}$ & $\begin{array}{r}112 \\
151 \\
76 \\
* 173\end{array}$ & $\begin{array}{r}3.54 \\
3.96 \\
3.09 \\
a / 4.17\end{array}$ & $\begin{array}{l}\text { Dec. } 2,1980 \\
\text { July } 13,1981 \\
\text { July } 27,1981 \\
\text { Aug. } 5,1981\end{array}$ & $\begin{array}{l}1730 \\
2300 \\
0300 \\
1800\end{array}$ & $\begin{array}{r}96 \\
* 335 \\
228 \\
94\end{array}$ & $\begin{array}{l}3.33 \\
5.40 \\
4.63 \\
3.33\end{array}$ \\
\hline $\begin{array}{l}\text { Sept. } 15,1973 \\
\text { Nov. } 17,1973 \\
\text { June } 6,1974 \\
\text { June } 20,1974 \\
\text { July } 2,1974\end{array}$ & $\begin{array}{l}2200 \\
1900 \\
0030 \\
0100 \\
1700\end{array}$ & $\begin{array}{r}* 240 \\
81 \\
83 \\
88 \\
* 156\end{array}$ & $\begin{array}{l}4.72 \\
2.86 \\
3.18 \\
3.25 \\
4.01\end{array}$ & $\begin{array}{l}\text { Oct. } 31,1981 \\
\text { Dec. } 23,1981 \\
\text { Feb. } 6,1982 \\
\text { Mar. 22, } 1982 \\
\text { June } 21,1982\end{array}$ & $\begin{array}{l}0200 \\
0700 \\
0800 \\
2230 \\
0600\end{array}$ & $\begin{array}{r}71 \\
117 \\
128 \\
86 \\
+303\end{array}$ & $\begin{array}{r}3.02 \\
3.60 \\
a / 3.72 \\
3.22 \\
5.18\end{array}$ \\
\hline $\begin{array}{ll}\text { Nov. } 4, & 1974 \\
\text { Jan. } 21, & 1975\end{array}$ & $\begin{array}{r}+0800 \\
0300\end{array}$ & $\begin{array}{r}+\div 150 \\
102\end{array}$ & $3 . \overline{42}$ & & & & \\
\hline $\begin{array}{l}\text { Oct. } 9,1975 \\
\text { Oct. 17, } 1975 \\
\text { May 12, } 1976 \\
\text { Aug. 6, } 1976 \\
\text { Aug. 19, } 1976 \\
\text { Sept. 4, } 1976\end{array}$ & $\begin{array}{r}2300 \\
1730 \\
+0700 \\
+0700 \\
1300 \\
0500\end{array}$ & $\begin{array}{r}74 \\
82 \\
+100 \\
106 \\
+110 \\
75\end{array}$ & $\begin{array}{l}3.06 \\
3.17 \\
-- \\
3.47 \\
3.52 \\
3.07\end{array}$ & & & & \\
\hline
\end{tabular}

+ About

a/ From floodmark. 
Table 31. Streamflow records of Peemgoy Stream, Yap--Cont inued

B. Annual minimum discharge

\begin{tabular}{llllll}
\hline $\begin{array}{l}\text { Water } \\
\text { year }\end{array}$ & Date & $\begin{array}{c}\text { Discharge } \\
\left(\mathrm{ft}^{3} / \mathrm{s}\right)\end{array}$ & $\begin{array}{l}\text { Water } \\
\text { year }\end{array}$ & Date & $\begin{array}{c}\text { Discharge } \\
\left(\mathrm{ft}^{3} / \mathrm{s}\right)\end{array}$ \\
\hline 1968 al & Many days (87) & 0 & 1976 & Many days (15) & 0 \\
1969 & Many days (107) & 0 & 1977 & Many days (63) & 0 \\
1970 & Many days (68) & 0 & 1978 & Several days (8) & 0 \\
1971 & Many days & .01 & 1979 & Feb. 16, Mar. 30 & 0 \\
1972 & Many days (86) & 0 & 1980 & Feb. 2 & 0 \\
1973 & Many months (165) & 0 & 1981 & Many days (59) & 0 \\
1974 & Many days (16) & 0 & 1982 b/ & Many days & .01 \\
1975 & Many days (34) & 0 & & & \\
\hline a/ April to September 1968. & & & &
\end{tabular}




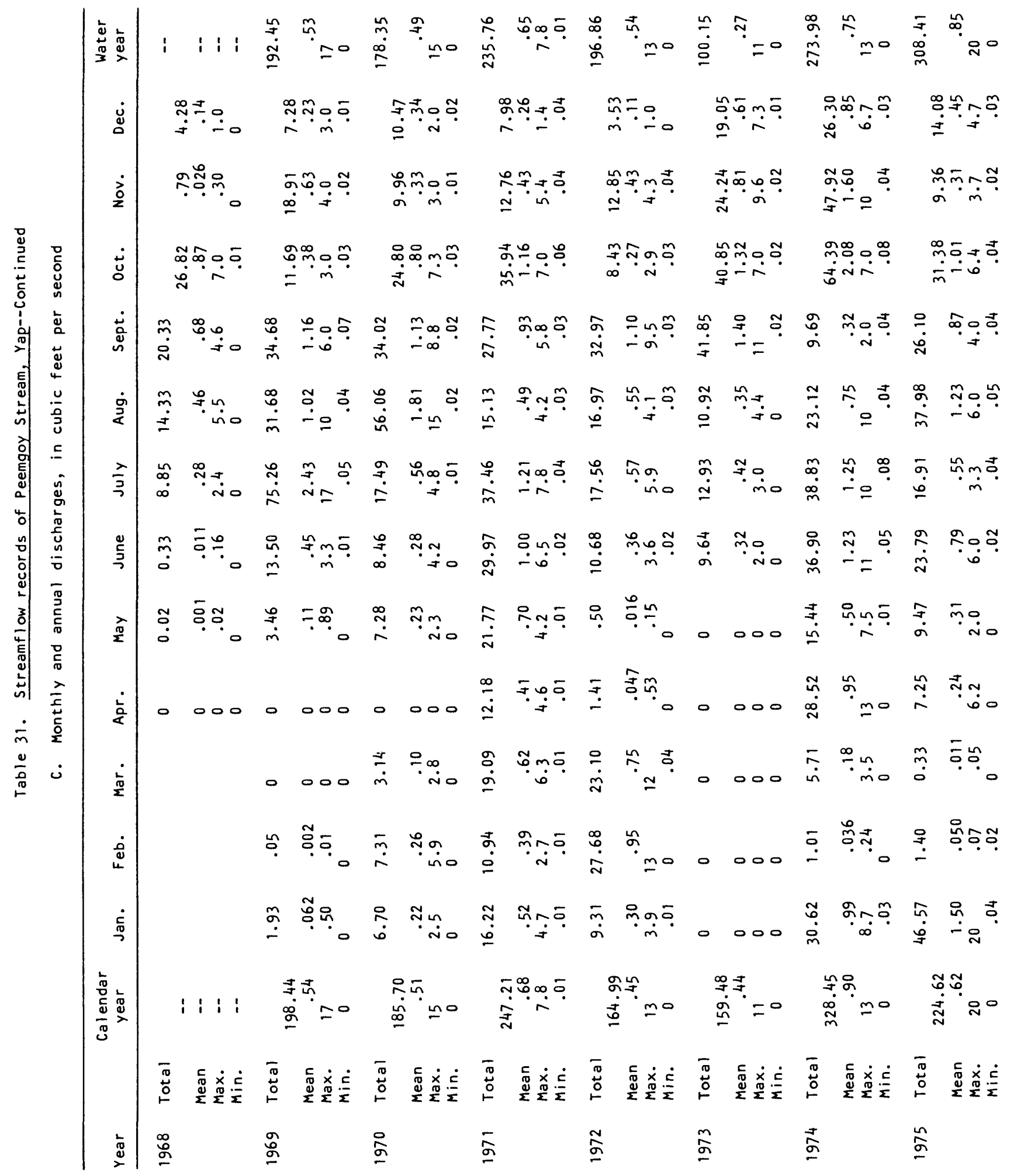




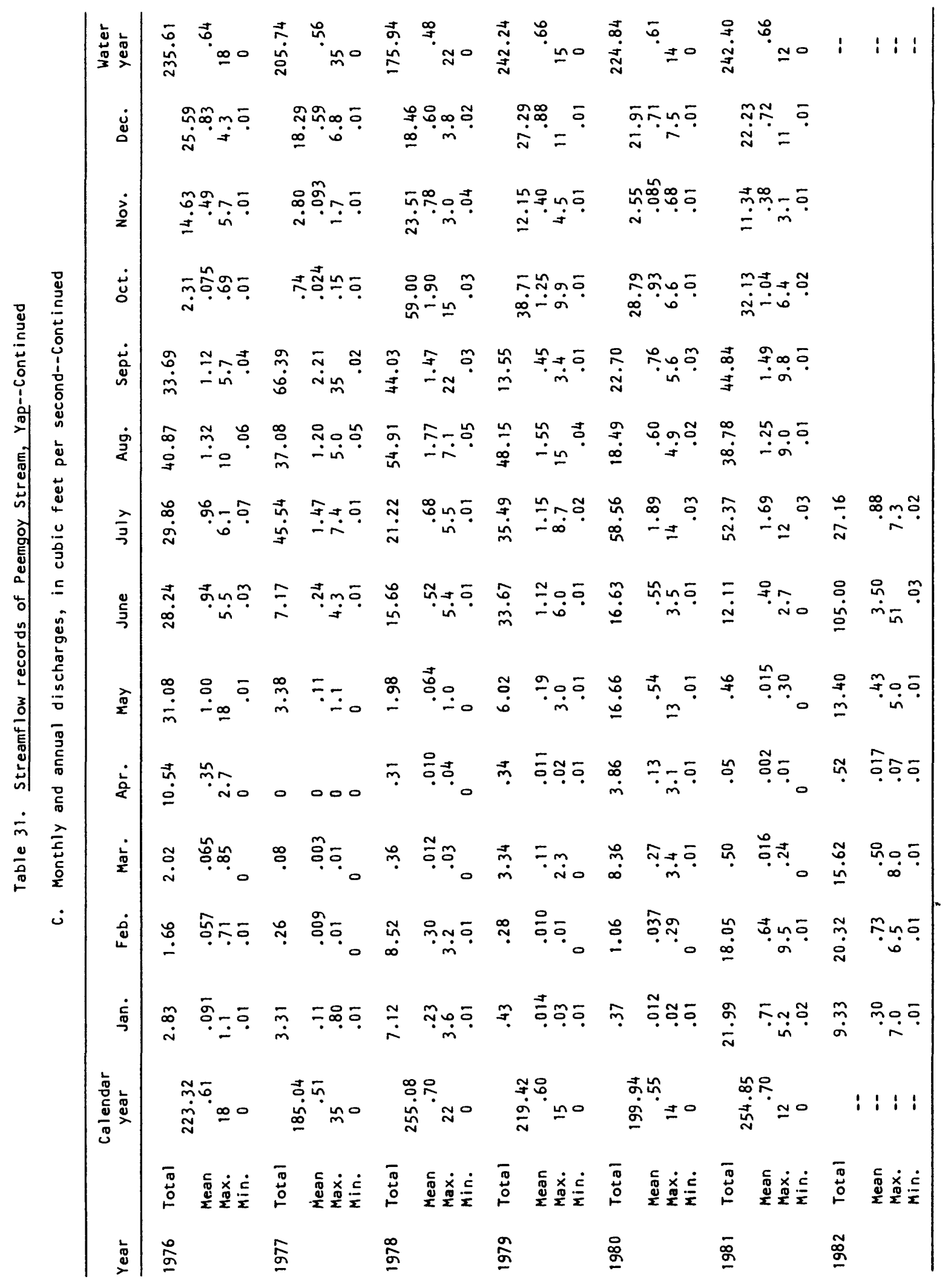


Table 32. Streamflow records of Taalgum Stream, Yap (16893000)

(Formerly published as Talagu Stream, Yap)

Location: Lat $9^{\circ} 31^{\prime} 09^{\prime \prime}$ N., long $138^{\circ} 06^{\prime} 32^{\prime \prime} \mathrm{E}$, , on left bank at Taalgum,

$300 \mathrm{ft}$ upstream from confluence with Pemgoy Stream, and $1.2 \mathrm{mi}$ northwest

of Protestant Mission Church in Colonia.

Drainage area: $0.08 \mathrm{mi}^{2}$.

Period of record: April 1968 to April 1979 (discontinued).

Gage: Water-stage recorder. Concrete control since Apr. 3, 1975. Altitude of gage is $100 \mathrm{ft}$ (from topographic map).

Remarks: Records fair. No diversion above station.

Average discharge: 10 years (water years 1969-78), $0.341 \mathrm{ft}^{3} / \mathrm{s}$ (247 acre-ft/yr). Extremes for period of record: Maximum discharge, $330 \mathrm{ft}^{3} / \mathrm{s}$ Sept. 14, 1978 (gage height, $3.98 \mathrm{ft}$ ), from rating curve extended above $9.0 \mathrm{ft}^{3} / \mathrm{s}$; no flow for many days each year.

A. Discharge measurements, in cubic feet per second, made outside the period of continuous discharge record

\begin{tabular}{|c|c|c|c|c|c|}
\hline Date & & Discharge & Date & & Discharge \\
\hline $9-20-65$ & 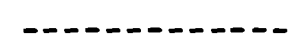 & 0.05 & $9-19-79$ & 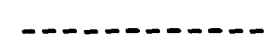 & $\mathrm{e} / 0.01$ \\
\hline $9-23-65$ & 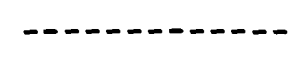 & .19 & $10-5-79$ & 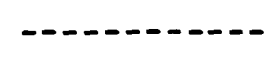 & .03 \\
\hline $10-9-67$ & 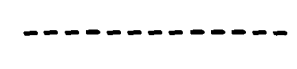 & .08 & $10-30-79$ & - - - - - - - & e/ .01 \\
\hline $6-13-79$ & 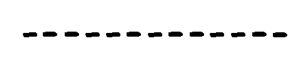 & .23 & $11-9-79$ & 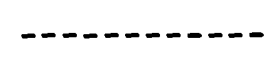 & e/ .01 \\
\hline $6-29-79$ & - - - - - - - - & .72 & $12-4-79$ & 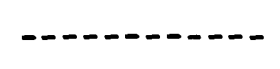 & e/ .01 \\
\hline $7-11-79$ & - - & 1.4 & $12-28-79$ & 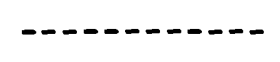 & .03 \\
\hline $7-26-79$ & $-\cdots+-1-n$ & .63 & $1-23-80$ & $-\ldots-\ldots$ & 0 \\
\hline $8-8-79$ & 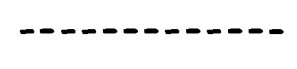 & .14 & $2-1-80$ & - - - - - - - & 0 \\
\hline $8-21-79$ & 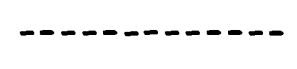 & .06 & $9-17-80$ & - - - - - - - - - & .56 \\
\hline $9-5-79$ & - & $\mathrm{e} / .01$ & $9-15-82$ & - & .25 \\
\hline
\end{tabular}

ef Estimated. 
Table 32. Streamflow records of Taalgum Stream, Yap--Continued

B. Annual maximum discharge $(*)$ and peak discharges above base $\left(50 \mathrm{ft}^{3} / \mathrm{s}\right)$

\begin{tabular}{|c|c|c|c|c|c|c|c|}
\hline Date & Time & $\begin{array}{l}\text { Dis- } \\
\text { charge } \\
\left(f t^{3} / \mathrm{s}\right)\end{array}$ & $\begin{array}{l}\text { Gage } \\
\text { height } \\
(f t)\end{array}$ & Date & Time & $\begin{array}{l}\text { Dis- } \\
\text { charge } \\
\left(f t^{3} / s\right)\end{array}$ & $\begin{array}{c}\text { Gage } \\
\text { height } \\
(f t)\end{array}$ \\
\hline Aug. 2, 1968 & 1300 & $* 66$ & 2.36 & 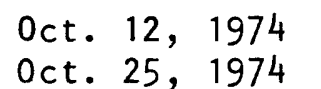 & $\begin{array}{l}2230 \\
1500\end{array}$ & $\begin{array}{l}54 \\
55\end{array}$ & $\begin{array}{l}2.17 \\
2.18\end{array}$ \\
\hline $\begin{array}{l}\text { July } 13,1969 \\
\text { July } 23,1969 \\
\text { Aug. } 5,1969\end{array}$ & $\begin{array}{l}0100 \\
0500 \\
0700\end{array}$ & $\begin{array}{r}55 \\
* 137 \\
85\end{array}$ & $\begin{array}{l}2.18 \\
3.22 \\
2.62\end{array}$ & $\begin{array}{ll}\text { Nov. } 4, & 1974 \\
\text { Jan. } 21, & 1975 \\
\text { Aug. } 26, & 1975\end{array}$ & $\begin{array}{l}0800 \\
0400 \\
1330\end{array}$ & $\begin{array}{r}* 114 \\
82 \\
63\end{array}$ & $\begin{array}{l}2.97 \\
2.58 \\
2.36\end{array}$ \\
\hline $\begin{array}{l}\text { Feb. } 23,1970 \\
\text { Aug. } 5,1970 \\
\text { Aug. } 15,1970 \\
\text { Aug. } 21,1970 \\
\text { Aug. } 26,1970 \\
\text { Sept. } 19,1970\end{array}$ & $\begin{array}{r}+0700 \\
2000 \\
0630 \\
1300 \\
1800 \\
1700\end{array}$ & $\begin{array}{r}85 \\
53 \\
65 \\
+145 \\
63 \\
138\end{array}$ & $\begin{array}{r}a / 2.63 \\
2.15 \\
2.34 \\
3.30 \\
2.31 \\
3.23\end{array}$ & $\begin{array}{l}\text { Oct. } 9,1975 \\
\text { Oct. } 17,1975 \\
\text { May } 12,1976 \\
\text { Aug. } 6,1976 \\
\text { Aug. 19, } 1976 \\
\text { Sept. 4, } 1976\end{array}$ & $\begin{array}{l}2300 \\
1730 \\
0700 \\
0700 \\
1300 \\
0500\end{array}$ & $\begin{array}{r}85 \\
* 128 \\
127 \\
108 \\
113 \\
+55\end{array}$ & $\begin{array}{r}2.57 \\
2.91 \\
2.90 \\
a / 2.76 \\
a / 2.80 \\
-.-\end{array}$ \\
\hline $\begin{array}{ll}\text { Oct. } 14, & 1970 \\
\text { Jan. } 20, & 1971\end{array}$ & $\begin{array}{l}0230 \\
2300\end{array}$ & $\begin{array}{l}72 \\
57\end{array}$ & $\begin{array}{l}2.44 \\
2.22\end{array}$ & Sept. 3, 1977 & 1000 & $* 79$ & 2.52 \\
\hline $\begin{array}{l}\text { Apr. 24, } 1971 \\
\text { July 8, } 1971 \\
\text { Sept. 6, } 1971\end{array}$ & $\begin{array}{r}0500 \\
+2400 \\
0930\end{array}$ & $\begin{array}{r}63 \\
57 \\
\div 81\end{array}$ & $\begin{array}{r}2.32 \\
a / 2.21 \\
2.57\end{array}$ & $\begin{array}{l}\text { Nov. } 27,1977 \\
\text { Dec. } 12,1977 \\
\text { June } 21,1978 \\
\text { Aug. } 3,1978\end{array}$ & $\begin{array}{l}0800 \\
0200 \\
1930 \\
1300\end{array}$ & $\begin{array}{l}56 \\
54 \\
65 \\
61\end{array}$ & $\begin{array}{r}a / 2.28 \\
2.26 \\
2.38 \\
2.33\end{array}$ \\
\hline $\begin{array}{l}\text { Mar. 6, } 1972 \\
\text { Sept. 8, } 1972\end{array}$ & $\begin{array}{l}1100 \\
0200\end{array}$ & $\begin{array}{r}115 \\
+117\end{array}$ & $\begin{array}{r}2.98 \\
a / 3.00\end{array}$ & $\begin{array}{ll}\text { Sept. } 14, & 1978 \\
\text { Sept. } 17, & 1978\end{array}$ & $\begin{array}{l}0300 \\
1230\end{array}$ & $\begin{array}{r}* 330 \\
255\end{array}$ & $\begin{array}{l}3.98 \\
3.65\end{array}$ \\
\hline Sept. 15, 1973 & 2300 & $* 213$ & 3.98 & $\begin{array}{lll}\text { July } & 3, & 1979 \\
\text { Aug. } & 17, & 1979\end{array}$ & $\begin{array}{l}+1900 \\
+0900\end{array}$ & $\begin{array}{r}61 \\
* 164\end{array}$ & $\begin{array}{l}a / 2.33 \\
a / 3.14\end{array}$ \\
\hline $\begin{array}{l}\text { Apr. } 20,1974 \\
\text { June } 6,1974 \\
\text { June } 20,1974 \\
\text { July } 2,1974\end{array}$ & $\begin{array}{l}1200 \\
0130 \\
0130 \\
1730\end{array}$ & $\begin{array}{r}63 \\
68 \\
63 \\
+141\end{array}$ & $\begin{array}{l}2.31 \\
2.38 \\
2.32 \\
3.26\end{array}$ & & & & \\
\hline
\end{tabular}

+ About.

a/ From floodmark. 
Table 32. Streamflow records of Taalgum Stream, Yap--Continued c. Annual minimum discharge

\begin{tabular}{llclll}
\hline $\begin{array}{l}\text { Water } \\
\text { year }\end{array}$ & Date & $\begin{array}{c}\text { Discharge } \\
\left(\mathrm{ft}^{3} / \mathrm{s}\right)\end{array}$ & $\begin{array}{l}\text { Water } \\
\text { year }\end{array}$ & Date & $\begin{array}{c}\text { Discharge } \\
\left(\mathrm{ft}^{3} / \mathrm{s}\right)\end{array}$ \\
\hline 1968 a/ & Many days (111) & 0 & 1974 & Many days (42) & 0 \\
1969 & Many days (183) & 0 & 1975 & Many days (78) & 0 \\
1970 & Many days (178) & 0 & 1976 & Many days (58) & 0 \\
1971 & April 7,8 & 0 & 1977 & Many days (91) & 0 \\
1972 & Many days (74) & 0 & 1978 & Many days (137) & 0 \\
1973 & Many days (177) & 0 & $1979 \underline{\text { b } /}$ & Many days (106) & 0 \\
\hline
\end{tabular}

af April to September 1968.

b/ October 1978 to April 1979. 


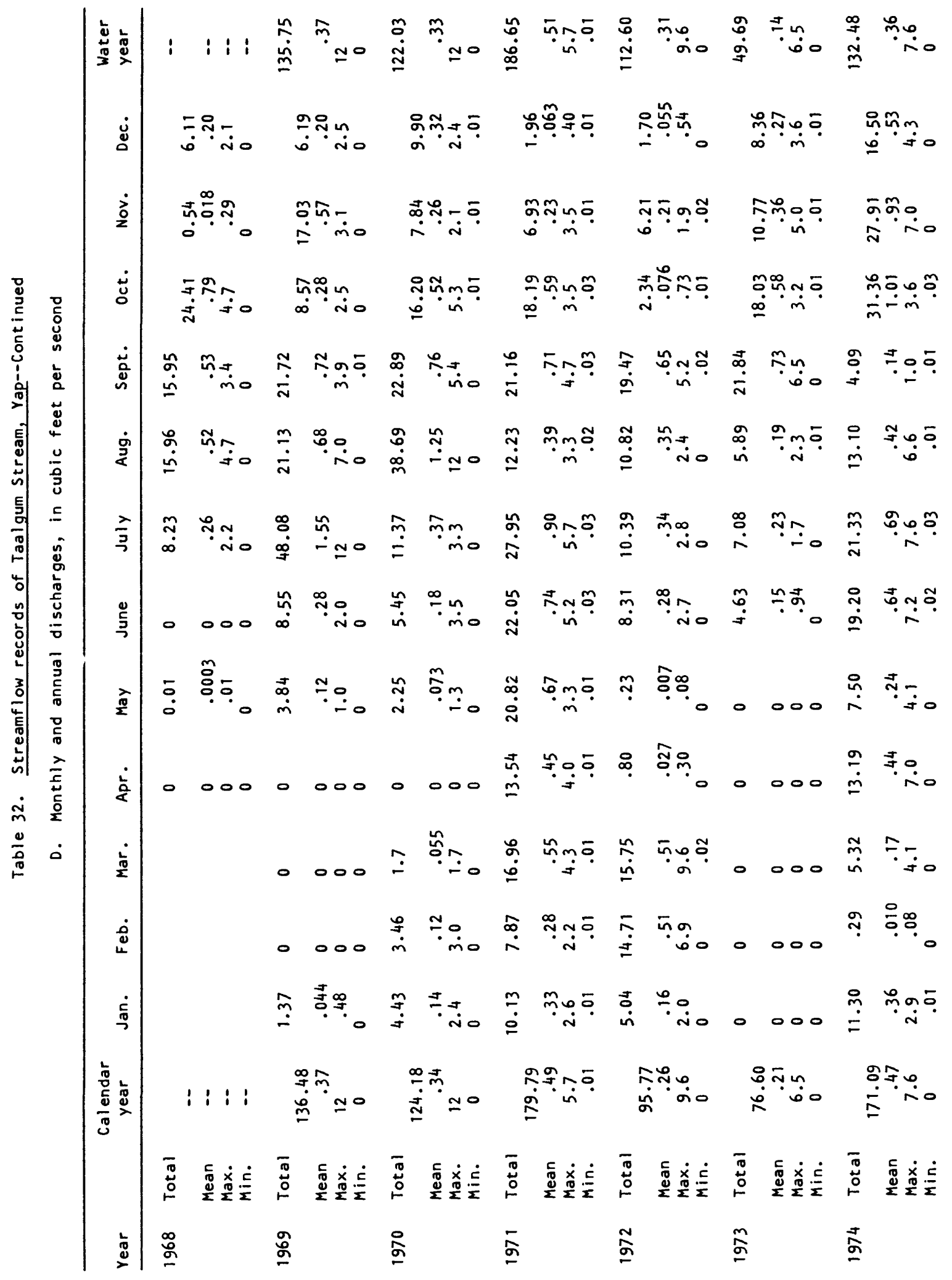




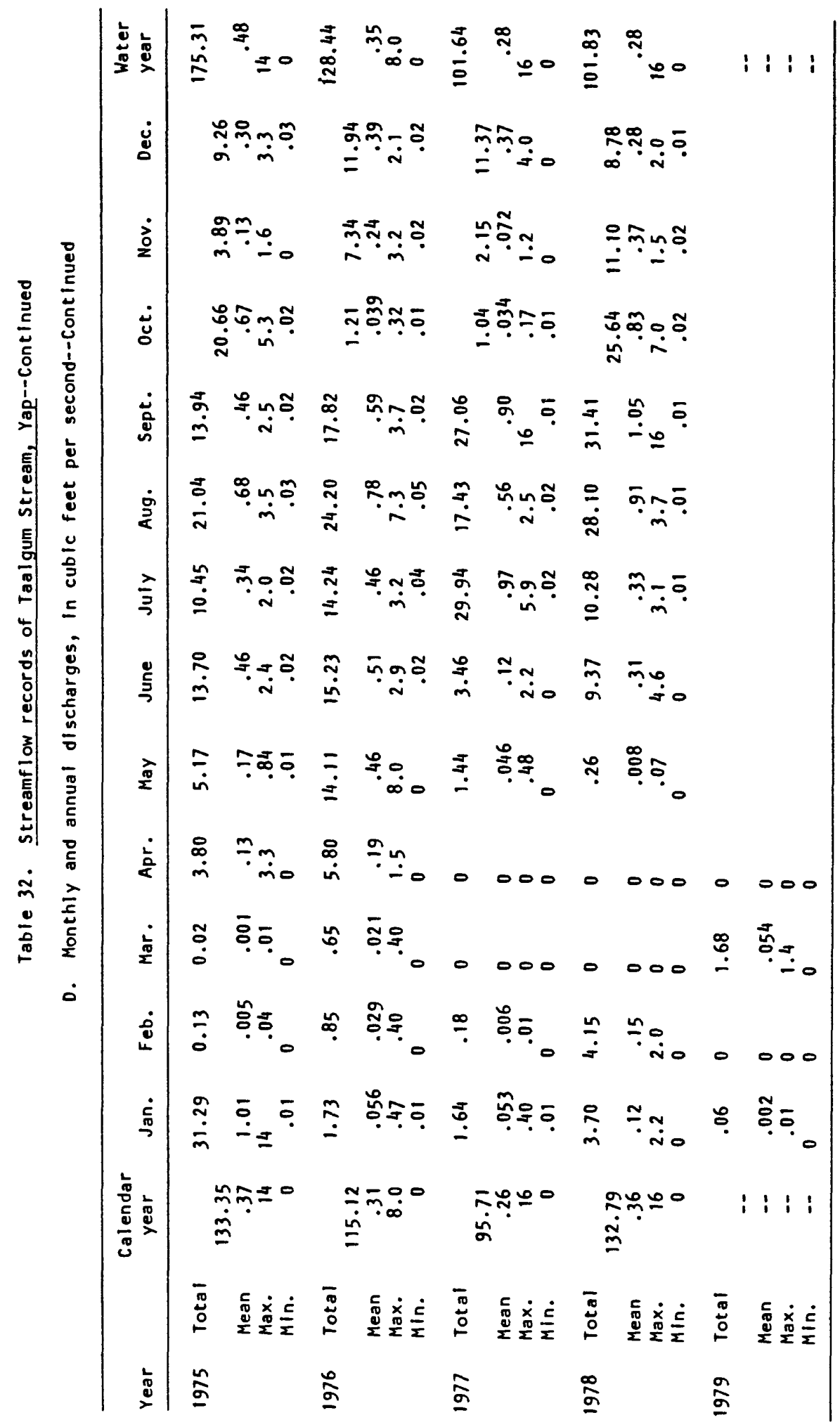


Table 33. Streamflow records for Burong Stream, Yap, (16893100)

Location: Lat $9^{\circ} 32^{\prime} 05^{\prime \prime}$ N., long $138^{\circ} 07^{\prime} 19^{\prime \prime} \mathrm{E}$., on left bank at Dugor, $0.25 \mathrm{mi}$ upstream from mouth, and $0.5 \mathrm{mi}$ northeast of Mount Gamuw. Drainage area: $0.23 \mathrm{mi}^{2}$.

Period of record: April 1968 to September 1982.

Gage: Water-stage recorder and concrete control. Altitude of gage is $15 \mathrm{ft}$ (from topographic map).

Remarks: Records good. No diversion above station.

Average discharge: 14 years, $0.973 \mathrm{ft}^{3} / \mathrm{s}(705$ acre-ft/yr).

Extremes for period of record: Maximum discharge, $550 \mathrm{ft}^{3} / \mathrm{s}$ June 21, 1982

(gage height, $5.45 \mathrm{ft}$ ), from rating curve extended above $15 \mathrm{ft}^{3} / \mathrm{s}$;

no flow for many days most years. 
Table 33. Streamflow records of Burong Stream, Yap--Continued

A. Annual maximum discharge $(*)$ and peak discharges above base $\left(75 \mathrm{ft}^{3} / \mathrm{s}\right)$

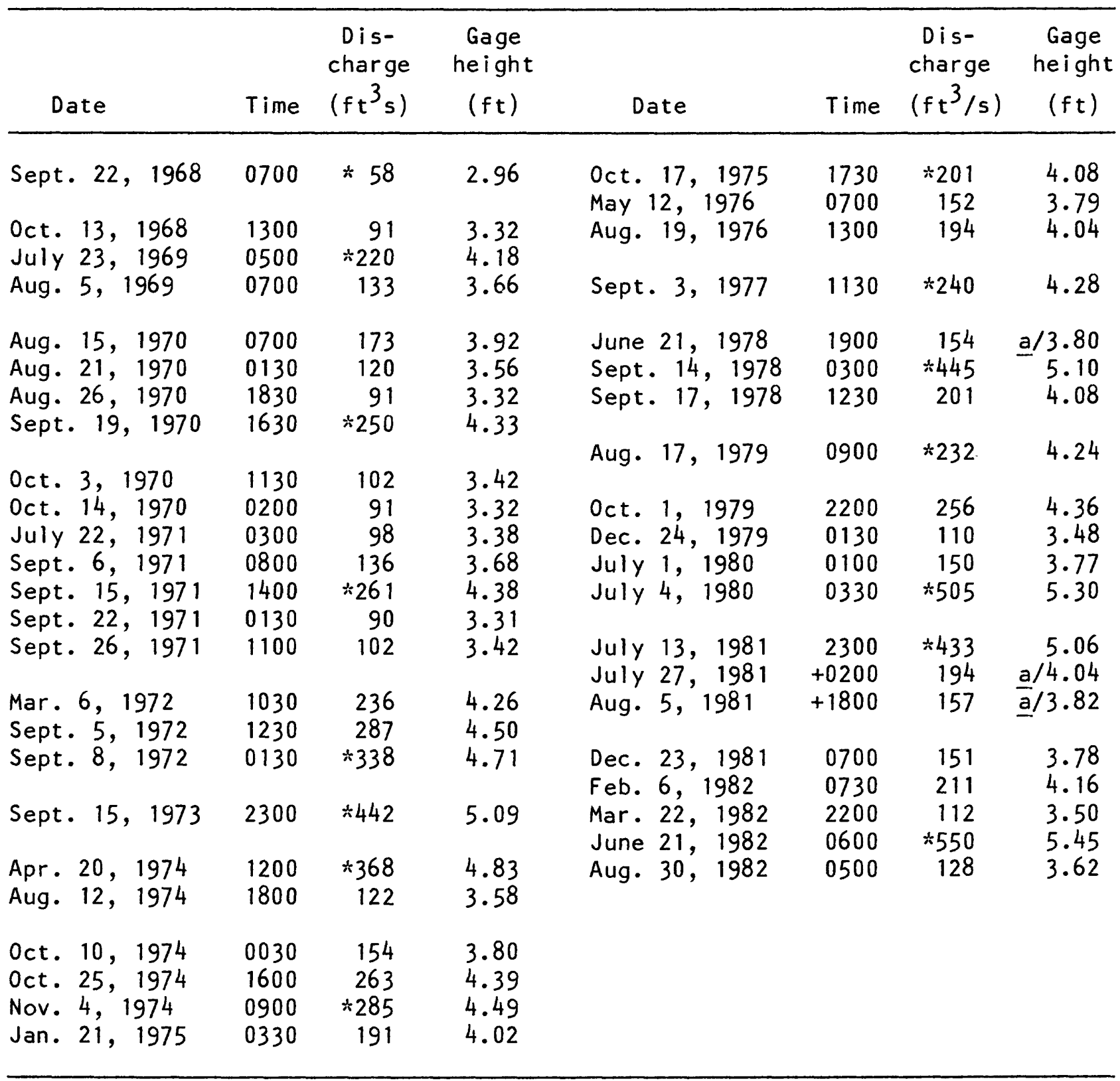

+ About.

a/ From floodmarks. 
Table 33. Streamflow records of Burong Stream, Yap--Continued

B. Annual minimum discharge

\begin{tabular}{llcllc}
\hline $\begin{array}{l}\text { Water } \\
\text { year }\end{array}$ & Date & $\begin{array}{c}\text { Discharge } \\
\left(\mathrm{ft}^{3} / \mathrm{s}\right)\end{array}$ & $\begin{array}{c}\text { Water } \\
\text { year }\end{array}$ & Date & $\begin{array}{c}\text { Discharge } \\
\left(\mathrm{ft}^{3} / \mathrm{s}\right)\end{array}$ \\
\hline 1968 a / & Many days (100) & 0 & 1976 & Many days (65) & 0 \\
1969 & Many days (179) & 0 & 1977 & Many days (131) & 0 \\
1970 & Many days (91) & 0 & 1978 & Many days (126) & 0 \\
1971 & February 1 & .01 & 1979 & Many days (132) & 0 \\
1972 & Many days (44) & 0 & 1980 & Many days (83) & 0 \\
1973 & Many days (172) & 0 & 1981 & Many days (94) & 0 \\
1974 & Many days (22) & 0 & 1982 & Many days (32) & 0 \\
1975 & Many days (84) & 0 & & & \\
\hline
\end{tabular}

af April to September 1968 . 


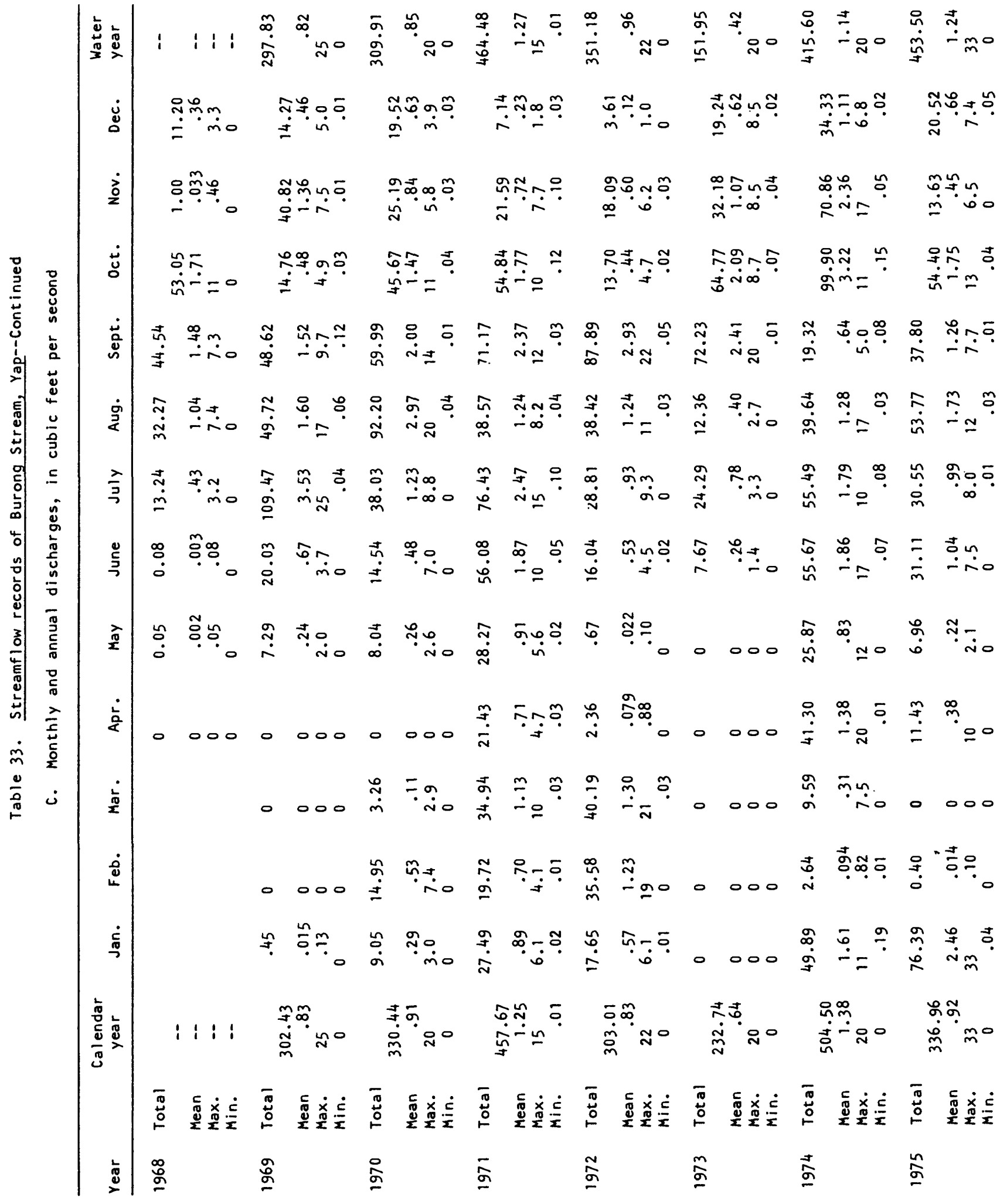




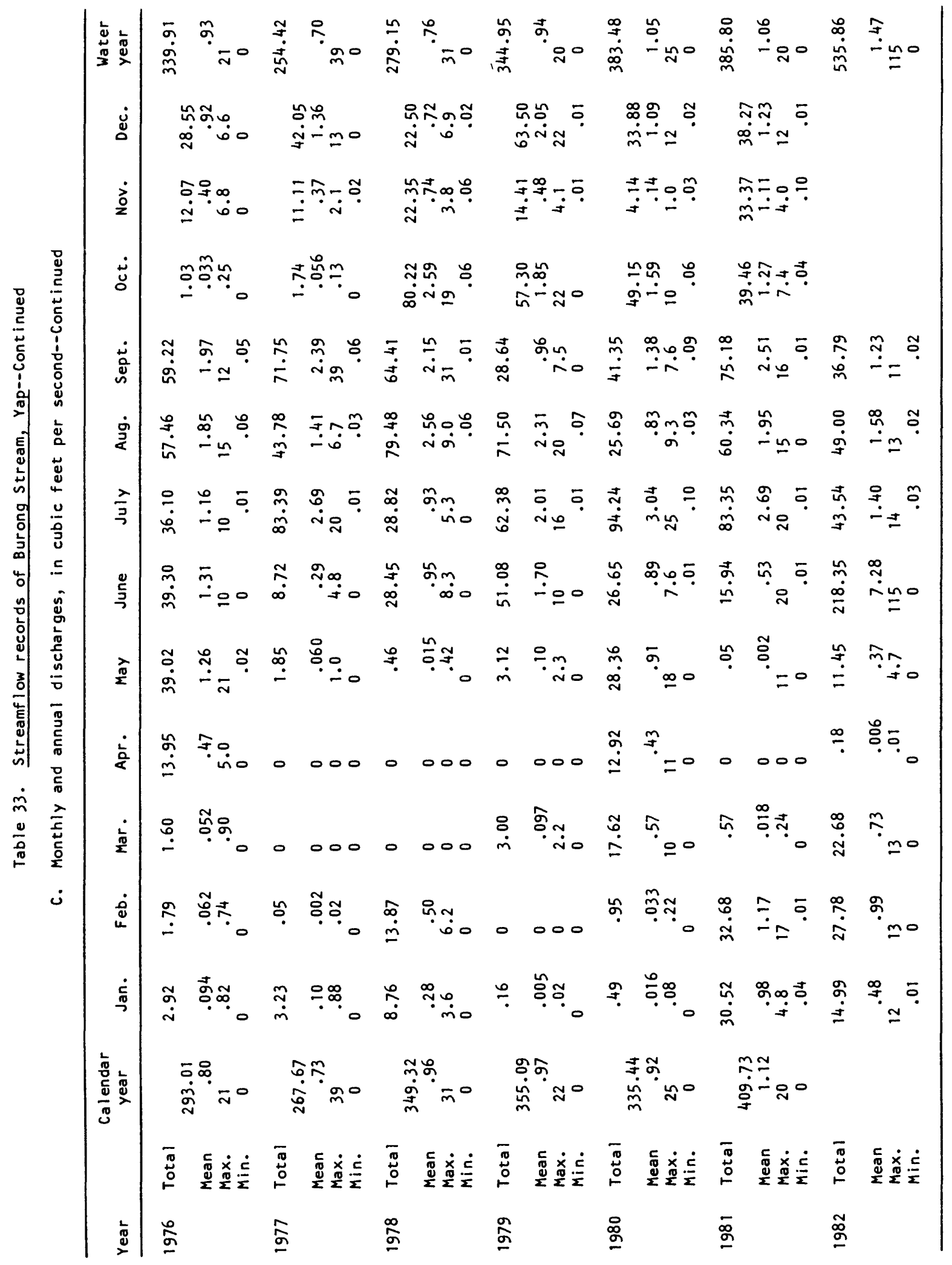


Table 34. Streamflow records of Mukong Stream, Gagil-Tamil (16893200)

Location: Lat $9^{\circ} 32^{\prime} 05^{\prime \prime} \mathrm{N}$. , long $138^{\circ} 10^{\prime} 18^{\prime \prime} \mathrm{E}$., on right bank $0.2 \mathrm{mi}$ upstream from mouth and $0.9 \mathrm{mi}$ south of U.S. Coast Guard LORAN station. Drainage area: $0.50 \mathrm{mi}^{2}$.

Period of record: 0ccasional low-flow measurements, water years 1972-75. Continuous record December 1974 to June 1978, October 1978 to September 1982 (July to September 1978, stage-discharge relation indefinite due to blocked control).

Gage: Water-stage recorder. Altitude of gage is $5 \mathrm{ft}$ (from topographic map).

Remarks: Records fair. Since 1978, small amount of water is pumped at times from site about $500 \mathrm{ft}$ upstream for domestic use in nearby village.

Average discharge: 6 years (water years, 1976-77, 1979-82), $2.08 \mathrm{ft}^{3} / \mathrm{s}(1,510$ acre-ft/yr).

Extremes for period of continuous record: Maximum discharge, $153 \mathrm{ft}^{3} / \mathrm{s}$ June 21, 1982 (gage height, 4.10 ft), from rating curve extended above 18 $\mathrm{ft}^{3} / \mathrm{s}$; minimum discharge, $0.07 \mathrm{ft}^{3} / \mathrm{s} \mathrm{Apr.} \mathrm{9,} \mathrm{1979,} \mathrm{Mar.} \mathrm{15,} \mathrm{1980,}$ May 4, 1981. 
Table 34. Streamflow records of Mukong Stream, Gagil-Tamil--Cont inued

A. Discharge measurements, in cubic feet per second, made outside the periods of continuous discharge record

\begin{tabular}{|c|c|c|c|c|c|c|}
\hline Date & Discharge & Date & & Discharge & Date & Discharge \\
\hline $12-4-71-\cdots$ & 0.55 & $1-29-73$ & --- & 0.21 & $4-19-74 \quad--$ & 1.3 \\
\hline $1-14-72-\cdots$ & .93 & $2-16-73$ & --- & .06 & $5-7-74---$ & .65 \\
\hline $2-24-72 \cdots$ & 6.9 & $2-26-73$ & -- & .12 & $5-17-74 \quad--$ & 1.4 \\
\hline $3-23-72-\cdots$ & 3.3 & $5-7-73$ & -- & .18 & $6-5-74-\cdots$ & 8.7 \\
\hline $4-21-72---$ & 1.7 & $6-20-73$ & -- & .35 & $7-10-74 \ldots$ & 3.0 \\
\hline $5-18-72-\cdots$ & .28 & $7-2-73$ & -- & 3.7 & $8-16-74 \quad--$ & 2.2 \\
\hline $6-16-72 \cdots$ & 1.2 & $8-15-73$ & -- & .79 & $9-12-74 \quad \cdots$ & .98 \\
\hline $7-15-72---$ & 1.2 & $8-29-73$ & -- & 1.2 & $10-3-74=-$ & 3.1 \\
\hline $8-10-72---$ & 3.6 & $12-4-73$ & --- & 1.1 & $7-21-78---$ & .86 \\
\hline $10-12-72-\cdots$ & 1.1 & $1-16-74$ & -- & 2.8 & $8-30-78 \cdots$ & 2.4 \\
\hline $10-16-72 \ldots$ & 1.2 & $2-4-74$ & $\cdots$ & 1.2 & $9-14-78 \quad \cdots$ & 6.1 \\
\hline $12-19-72 \ldots$ & 1.1 & $2-14-74$ & -- & 1.5 & $9-29-78 \quad \cdots$ & 1.6 \\
\hline $1-9-73 \ldots$ & .28 & $3-7-74$ & $\cdots$ & .34 & & \\
\hline
\end{tabular}


Table 34. Streamflow records of Mukong Stream, Gagil-Tamil--Continued

B. Annual maximum discharge $(*)$ and peak discharges above base $\left(25 \mathrm{ft}^{3} / \mathrm{s}, 1974-79 ; 50 \mathrm{ft}^{3} / \mathrm{s}, 1980-82\right)$

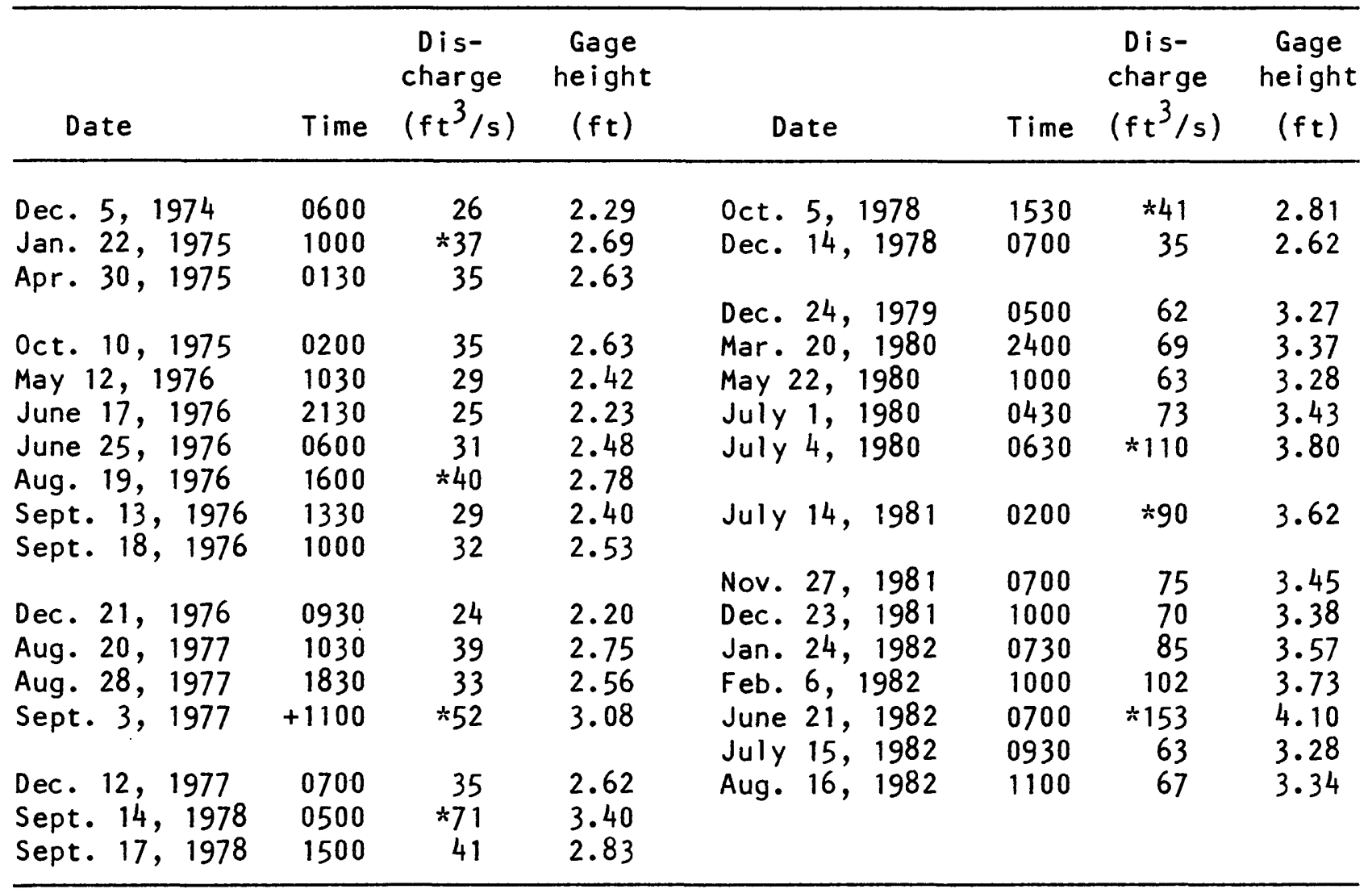

+ About.

C. Annual minimum discharge

\begin{tabular}{|c|c|c|c|c|c|}
\hline $\begin{array}{l}\text { Water } \\
\text { year }\end{array}$ & Date & $\begin{array}{c}\text { Discharge } \\
\left(\mathrm{ft}^{3} / \mathrm{s}\right)\end{array}$ & $\begin{array}{l}\text { Water } \\
\text { year }\end{array}$ & Date & $\begin{array}{c}\text { Discharge } \\
\left(\mathrm{ft}^{3} / \mathrm{s}\right)\end{array}$ \\
\hline $\begin{array}{l}1975^{\text {al }} \\
1976 \\
1977 \\
1978\end{array}$ & $\begin{array}{l}\text { Several days in } \\
\text { April } \\
\text { March 15-17 } \\
\text { Part of each day, } \\
\text { April 3-9 } \\
\text { Several days in } \\
\text { April, May }\end{array}$ & $\begin{array}{r}0.11 \\
.12 \\
.11 \\
.09\end{array}$ & $\begin{array}{l}1979 \\
1980 \\
1981 \\
1982\end{array}$ & $\begin{array}{l}\text { April } 9 \\
\text { March } 15 \\
\text { May } 4 \\
\text { March } 5,6\end{array}$ & $\begin{array}{r}0.07 \\
.07 \\
.07 \\
.20\end{array}$ \\
\hline
\end{tabular}

af December 1974 to September 1975. 


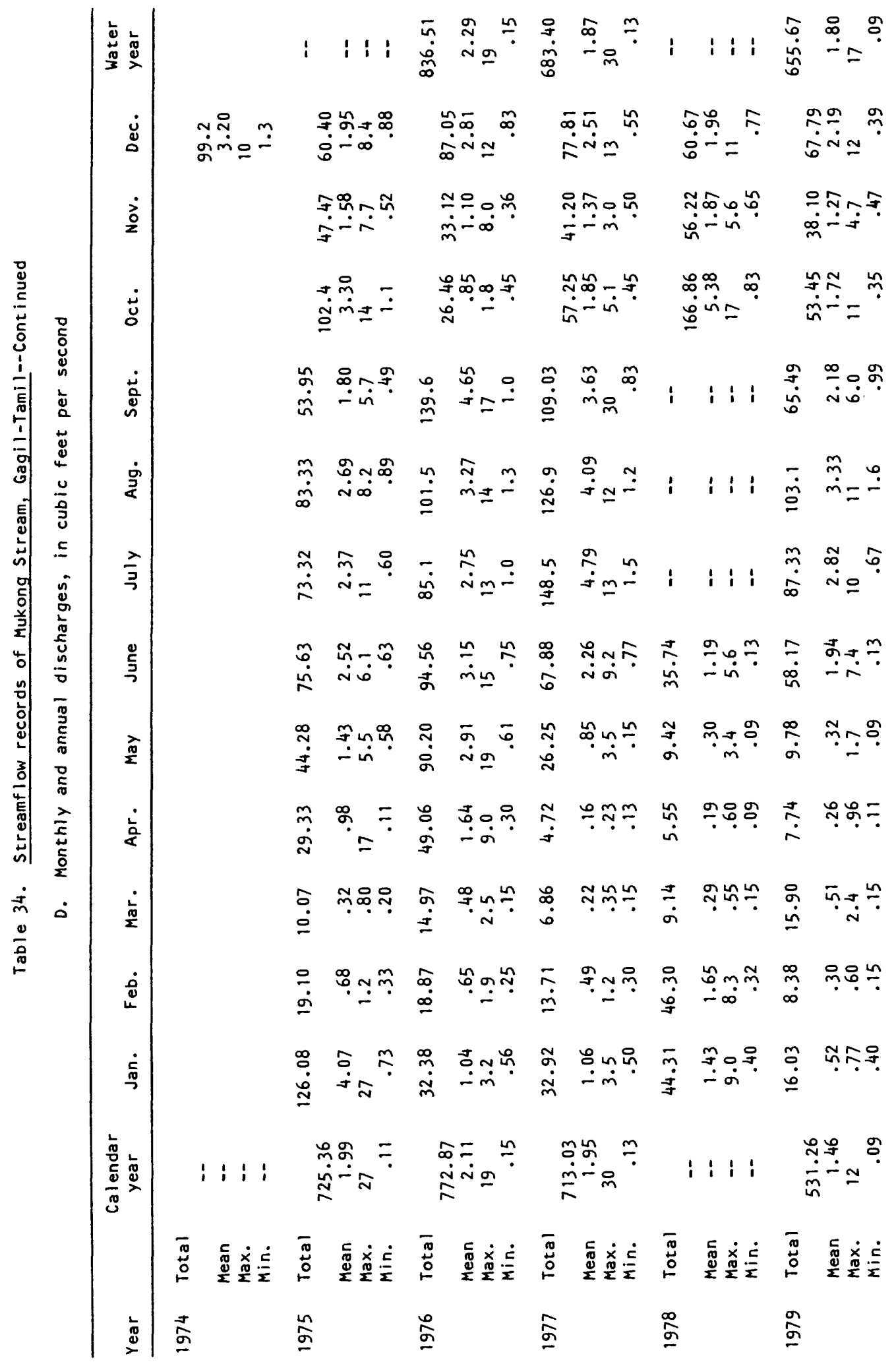




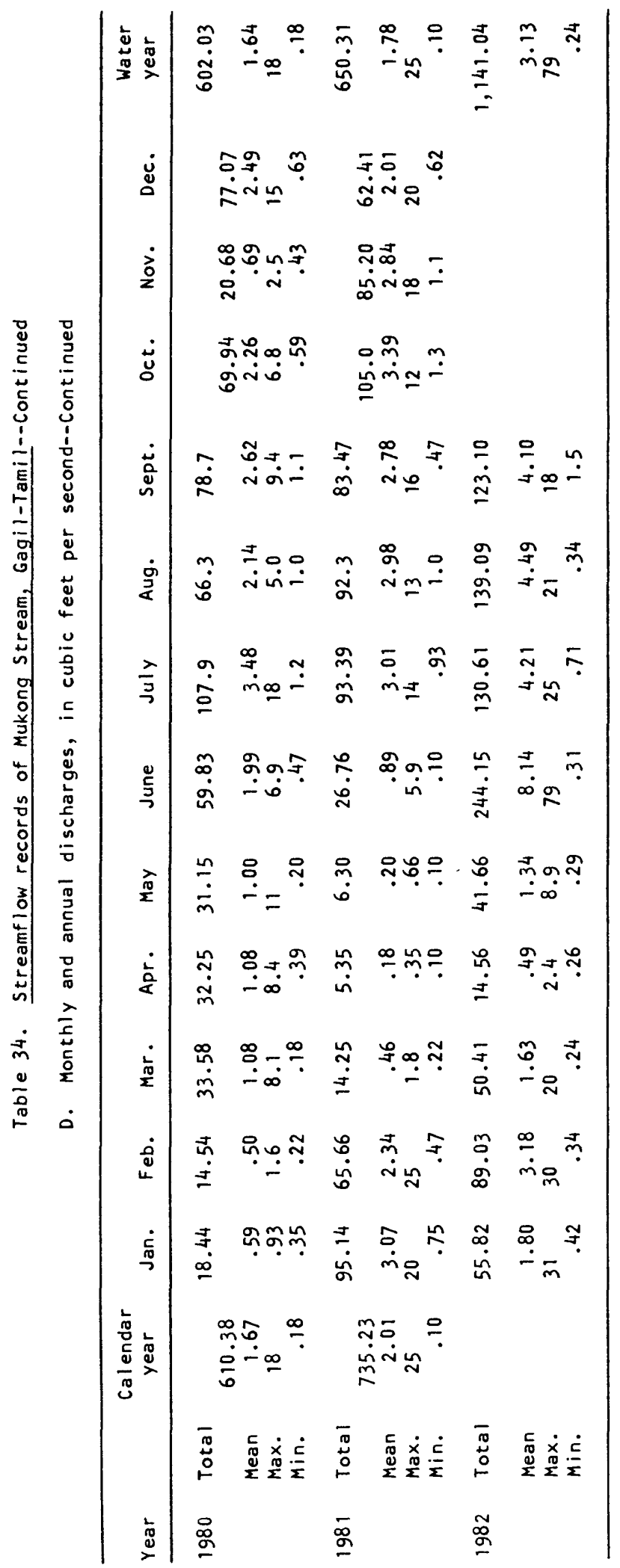


Table 35. Streamflow records of Gilaew Spring, Gagil-Tamil (16893300)

(Formerly published as Bileiy Spring, Gagil-Tomil)

Location: Lat $9^{\circ} 32^{\prime} 16^{\prime \prime} \mathrm{N}$. , long $138^{\circ} 11^{\prime} 17^{\prime \prime} \mathrm{E}$. , on right bank at Binaew,

$200 \mathrm{ft}$ downstream from main spring and $0.5 \mathrm{mile}$ southwest of Gagil Elementary School.

Period of record: Continuous-record station April 1968 to September 1974

(discontinued). Low-flow partial-record station 1975-82.

Gage: Water-stage recorder until September 1974. Altitude is $60 \mathrm{ft}$ (from

topographic map).

Average discharge: 6 years, $0.129 \mathrm{ft}^{3} / \mathrm{s}(93.4$ acre-ft/yr).

Remarks: Records fair. No diversion above station.

Extremes for period of continuous record: Maximum daily discharge, $1.5 \mathrm{ft}^{3} / \mathrm{s}$

Sept. 8, 1972; no flow for many days in 1968-69, 1973.

A. Discharge measurements, in cubic feet per second, made after the end of continuous discharge record

\begin{tabular}{|c|c|c|c|c|c|c|}
\hline Date & Discharge & Date & & Discharge & Date & Discharge \\
\hline $10-3-74=-$ & 0.05 & $5-19-76$ & --- & 0.42 & $7-21-78---$ & 0.03 \\
\hline $11-9-74--$ & .45 & $8-9-76$ & --- & .09 & $8-30-78---$ & .02 \\
\hline $4-2-75=--$ & $\underline{\mathrm{e}} / .01$ & $10-10-76$ & --- & .07 & $10-26-78---$ & .02 \\
\hline $4-30-75 \cdots$ & .10 & $12-2-76$ & -- & .20 & $11-28-78---$ & .02 \\
\hline $7-8-75-\cdots$ & .18 & $1-20-77$ & --- & .07 & $12-28-78---$ & 0 \\
\hline $8-27-75---$ & .16 & $11-29-77$ & --- & .01 & $12-27-79---$ & .18 \\
\hline $10-7-75---$ & .10 & $12-29-77$ & --- & .03 & $9-16-80---$ & .40 \\
\hline $12-3-75---$ & .04 & $2-1-78$ & -- & .03 & $10-20-80---$ & .21 \\
\hline $1-8-76--$ & .08 & $3-15-78$ & --- & .02 & $7-18-81--$ & .11 \\
\hline $4-1-76=-$ & .05 & $4-12-78$ & -- & .01 & $5-6-82 \ldots$ & .02 \\
\hline
\end{tabular}

ef Estimated. 


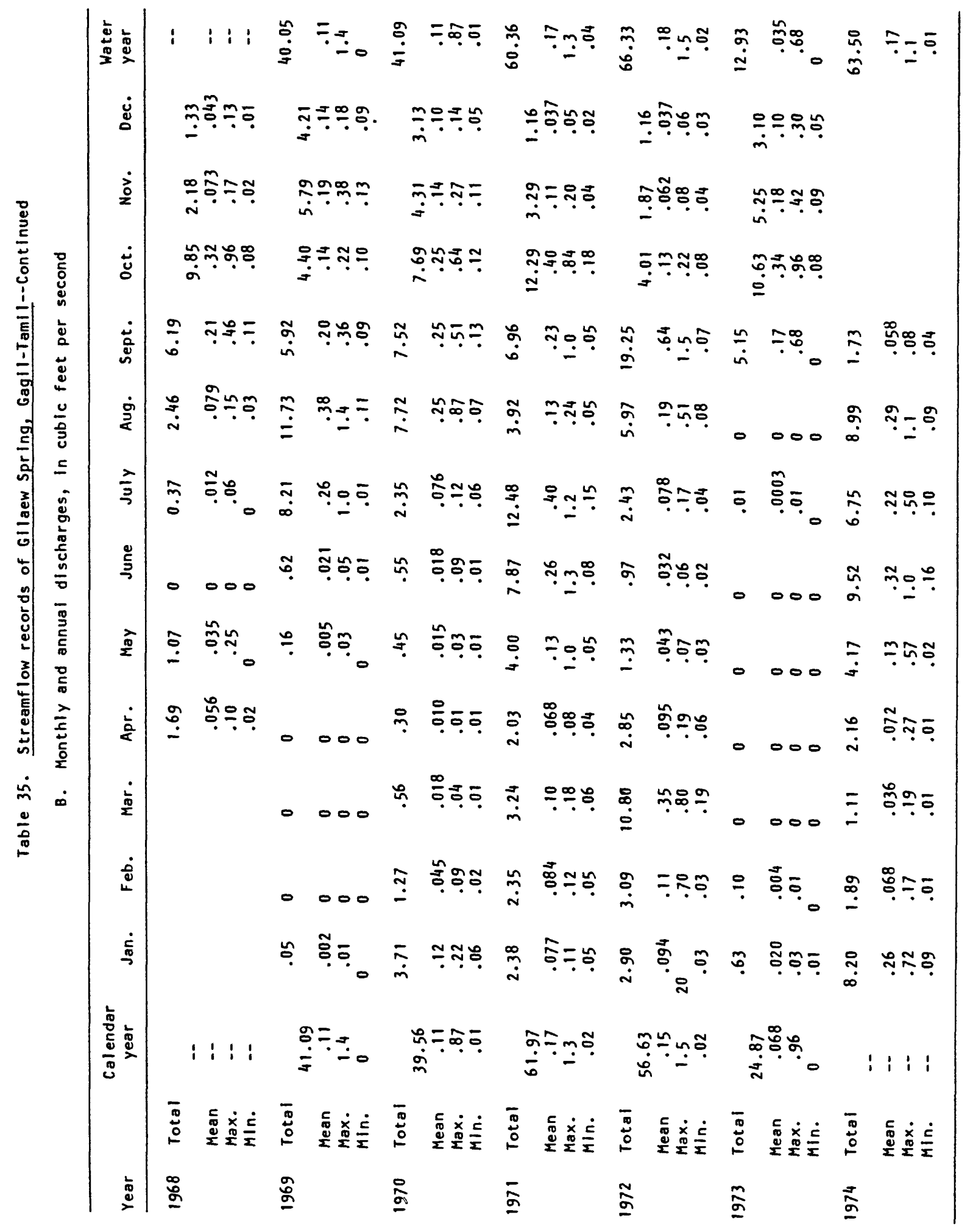


Table 36. Streamflow records of Eyeb Stream, Gagil-Tamil (16893400)

Location: Lat $9^{\circ} 33^{\prime} 11^{\prime \prime} \mathrm{N}$. , long $138^{\circ} 09^{\prime} 14^{\prime \prime} \mathrm{E} ., 0.6 \mathrm{mi}$ southeast of Tagireeng Canal bridge and $1.1 \mathrm{mi}$ northwest of U.S. Coast Guard LORAN station. Drainage area: $0.22 \mathrm{mi}^{2}$.

Period of record: 0ccasional low-flow measurements water years 1980-81.

Cont inuous record January to September 1982.

Gage: Water-stage recorder and concrete control. Altitude of gage is 15

$\mathrm{ft}$ (from topographic map).

Remarks: Records good. No diversion above station.

Extremes for period of record: Maximum discharge, $490 \mathrm{ft}^{3} / \mathrm{s}$ June 21 ,

1982 (gage height, $6.22 \mathrm{ft}$ ), from rating curve extended above $14 \mathrm{ft} 3 / \mathrm{s}$ on basis of estimate of peak flow; minimum discharge, $0.12 \mathrm{ft}^{3} / \mathrm{s}$ May 8 , $9,14,15,1982$.

A. Discharge measurements, in cubic feet per second, made outside the period of continuous discharge record

\begin{tabular}{|c|c|c|c|c|}
\hline Date & & Discharge & Date & Discharge \\
\hline $9-19-80$ & $-\cdots+-\cdots-1$ & 1.9 & $7-18-81-\cdots$ & 2.2 \\
\hline $10-20-80$ & --------- & 4.6 & $10-18-82-\cdots$ & .97 \\
\hline $3-24-81$ & -------- & .20 & $11-10-82-\cdots$ & .77 \\
\hline $4-7-81$ & ----------- & 19 & $11-24-82-\cdots$ & .58 \\
\hline $4-27-81$ & ---------- & .04 & $12-9-82--$ & 2.4 \\
\hline $5-14-81$ & $-\cdots-\cdots-1$ & .07 & $12-28-82-\cdots$ & .47 \\
\hline
\end{tabular}


Table 36. Streamflow records of Eyeb Stream, Gagil-Tamil--Continued

B. Monthly discharge, in cubic feet per second

\begin{tabular}{lcccccc}
\hline Year & & Jan. & Feb. & Mar. & Apr. & May \\
\hline \multirow{2}{*}{1982} & Total & 49.71 & 79.90 & 37.11 & 11.44 & 21.79 \\
& Mean & 1.60 & 2.85 & 1.20 & .38 & .70 \\
& Max. & 26 & 23 & 8.3 & 1.2 & 4.4 \\
& Min. & .41 & .69 & .36 & .19 & .15
\end{tabular}

\begin{tabular}{lccccc}
\hline Year & & June & July & Aug. & Sept. \\
\hline 1982 & Total & 291.17 & 122.77 & 95.70 & 80.37 \\
& Mean & 9.71 & 3.96 & 3.09 & 2.68 \\
& Max. & 130 & 27 & 20 & 15 \\
& Min. & .27 & .97 & .51 & .83 \\
\hline
\end{tabular}

Peak discharges above base $\left(150 \mathrm{ft}^{3} / \mathrm{s}\right)$ : Feb. $6(0830)$ $207 \mathrm{ft}^{3} / \mathrm{s}(4.66 \mathrm{ft})$; June $21(0430) 490 \mathrm{ft}^{3} / \mathrm{s}(6.22 \mathrm{ft})$; Aug. $16(0900) 153 \mathrm{ft}^{3} / \mathrm{s}(4.14 \mathrm{ft})$. 
Low-flow partial-record stations

Table 37. Discharge measurements, in cubic feet per second, of Faraq Swamp outlets, Yap (16892450)

Location: Lat $9^{\circ} 29^{\prime} 08^{\prime \prime}$ N., long $138^{\circ} 04^{\prime} 24^{\prime \prime} \mathrm{E}$., and lat $9^{\circ} 29^{\prime} 15^{\prime \prime} \mathrm{N}$. , long $138^{\circ} 04^{\prime} 21^{\prime \prime} \mathrm{E} ., 0.9 \mathrm{mi}$ northwest of Lamear and $4.1 \mathrm{mi}$ southwest of Colonia, at altitude $5 \mathrm{ft}$ (from topographic map).

Drainage area: $0.29 \mathrm{mi}^{2}$.

Period of record: 1968-73.

\begin{tabular}{|c|c|c|c|c|c|c|c|}
\hline Date & & Discharge & Date & & Discharge & Date & Discharge \\
\hline $10-9-67$ & -- & 0.25 & $11-25-70$ & -- & 0.22 & $10-20-71 \cdots$ & 0.08 \\
\hline $9-25-68$ & -- & .58 & $12-.18-70$ & -- & .25 & $2-24-72=-$ & .76 \\
\hline $9-20-69$ & $-\cdots$ & .48 & $11-12-70$ & -- & .12 & $3-23-72-\cdots$ & .12 \\
\hline $10-16-69$ & -- & .26 & $1-5-71$ & -- & .03 & $4-20-72 \cdots$ & .04 \\
\hline $6-4-70$ & $\cdots$ & .07 & $7-1-71$ & -- & .09 & $7-16-72 \ldots$ & .04 \\
\hline $7-30-70$ & -- & .30 & $7-7-71$ & -- & .20 & $8-10-72 \ldots$ & .16 \\
\hline $9-1-70$ & -- & 4.4 & $7-20-71$ & $\cdots$ & .24 & $9-20-72 \ldots$ & .30 \\
\hline $10-5-70$ & -- & .49 & $7-27-71$ & -- & .08 & $10-12-72-\cdots$ & .06 \\
\hline $10-30-70$ & -- & .14 & $8-4-71$ & -- & .04 & & \\
\hline
\end{tabular}


Table 38. Discharge measurements, in cubic feet per second, of Galngun Swamp outlet, Yap (16892460)

Location: Lat $9^{\circ} 29^{\prime} 04^{\prime \prime} \mathrm{N}$., long $138^{\circ} 04^{\prime} 40^{\prime \prime} \mathrm{E}, 0.5 \mathrm{mi}$ northwest of Lamear and $3.9 \mathrm{mi}$ southwest of Colonia, at altitude $30 \mathrm{ft}$ (from topographic map).

Drainage area: $0.16 \mathrm{mi}^{2}$.

Period of record: 1968-73.

\begin{tabular}{|c|c|c|c|c|c|}
\hline Date & Discharge & Date & Discharge & Date & Discharge \\
\hline $10-9-67-\cdots$ & 0.23 & $11-13-70=--$ & 0.25 & $10-20-71---$ & 0.16 \\
\hline $9-25-68 \cdots$ & .50 & $11-25-70=-$ & .34 & $1-13-72---$ & .26 \\
\hline $10-15-68---$ & 1.2 & $12-22-70 \quad-$. & .23 & $2-24-72 \ldots$ & .25 \\
\hline $9-20-69-\cdots$ & .40 & $1-5-71---$ & .14 & $3-23-72-\cdots$ & .29 \\
\hline $7-14-70 \quad \cdots$ & .15 & $1-28-71 \quad \cdots$ & .30 & $4-20-72 \ldots$ & .17 \\
\hline $7-30-70 \quad--$ & .24 & $6-30-71 \ldots$ & .05 & $5-18-72$ & .16 \\
\hline $9-1-70-\cdots$ & 2.8 & $7-7-71 \quad--$ & .35 & $7-15-72-\cdots$ & .20 \\
\hline $9-18-70 \ldots$ & .15 & $7-20-71---$ & .42 & $8-10-72 \quad \cdots$ & .21 \\
\hline $10-5-70 \cdots$ & .23 & $7-27-71 \cdots$ & .31 & $9-19-72 \ldots$ & .50 \\
\hline $10-29-70=-$ & .40 & $8-4-71-\cdots$ & .17 & $10-12-72=-$ & .23 \\
\hline
\end{tabular}


Table 39. Discharge measurements, in cubic feet per second,

of Tamaney Stream, Yap (16892500)

Location: Lat $9^{\circ} 29^{\prime} 49^{\prime \prime}$ N., long $138^{\circ} 05^{\prime} 52^{\prime \prime}$ E., at abandoned German dam,

$0.2 \mathrm{mi}$ upstream from mouth and $1.1 \mathrm{mi}$ southwest of U.S. Weather Bureau

Station at airport, at altitude $30 \mathrm{ft}$ (from topographic map).

Drainage area: $0.17 \mathrm{mi}^{2}$.

Period of record: 1968-82.

\begin{tabular}{|c|c|c|c|c|c|c|c|c|c|c|c|}
\hline Date & & Discharge & Date & & Discharge & Date & & Discharge & Date & & ischarge \\
\hline $8-22-68$ & -- & 0.97 & $12-22-70$ & -- & 0.04 & $5-24-74$ & -- & 1.6 & $12-30-77$ & --- & 0 \\
\hline $9-4-68$ & -- & .53 & $1-5-71$ & -- & .13 & $6-14-74$ & --- & .25 & $2-1-78$ & --- & .05 \\
\hline $10-17-68$ & -- & 3.2 & $1-27-71$ & --- & .04 & $7-14-74$ & --- & .26 & $3-16-78$ & --- & 0 \\
\hline $9-19-69$ & --- & .45 & $6-30-71$ & -- & . 1.1 & $9-13-74$ & -- & .27 & $6-29-78$ & --- & .09 \\
\hline $9-30-69$ & -- & .38 & $7-7-71$ & -- & .07 & $4-4-75$ & --- & 0 & $7-25-78$ & --- & 0 \\
\hline $10-14-69$ & -- & .15 & $7-20-71$ & -- & .06 & $5-2-75$ & --- & .25 & $8-31-78$ & --- & .07 \\
\hline $11-6-69$ & --- & .24 & $7-27-71$ & -- & .03 & $6-20-75$ & -- & 1.6 & $10-30-78$ & --- & .10 \\
\hline $11-20-69$ & -- & .06 & $8-4-71$ & --- & .06 & $7-15-75$ & -- & .52 & $11-30-78$ & --- & .10 \\
\hline $3-11-70$ & -- & 0 & $9-17-71$ & -- & .07 & $8-29-75$ & -- & .23 & $12-28-78$ & --- & 0 \\
\hline $3-24-70$ & --- & 0 & $10-20-71$ & --- & .74 & $10-9-75$ & --- & .14 & $6-29-79$ & --- & .81 \\
\hline $4-7-70$ & -- & 0 & $1-13-72$ & -- & .06 & $12-5-75$ & -- & .12 & $8-21-79$ & -- & .05 \\
\hline $4-29-70$ & --- & 0 & $2-24-72$ & -- & 11 & $1-9-76$ & -- & .04 & $12-27-79$ & --- & .16 \\
\hline $5-12-70$ & -- & .39 & $3-23-72$ & --- & .04 & $2-18-76$ & --- & $\mathrm{e} / .01$ & $2-1-80$ & -- & 0 \\
\hline $7-14-70$ & -- & .07 & $4-20-72$ & -- & .08 & $4-2-76$ & -- & .32 & $9-17-80$ & -- & 1.4 \\
\hline $7-30-70$ & --- & .39 & $7-15-72$ & -- & .06 & $5-21-76$ & -- & .15 & $10-20-80$ & -- & 1.1 \\
\hline $9-2-70$ & -- & 3.8 & $8-10-72$ & -- & .08 & $7-6-76$ & --- & .09 & $7-17-81$ & --- & .46 \\
\hline $9-22-70$ & -- & .38 & $9-20-72$ & --- & .09 & $8-11-76$ & --- & .74 & $5-5-82$ & --- & .05 \\
\hline $10-6-70$ & --- & .10 & $10-12-72$ & -- & .02 & $10-10-76$ & --- & 0 & $6-17-82$ & --- & .52 \\
\hline $10-29-70$ & -- & .07 & $2-19-74$ & -- & .18 & $12-3-76$ & -- & .23 & & & \\
\hline $11-13-70$ & --- & .14 & $3-11-74$ & -- & .20 & $1-21-77$ & -- & .26 & & & \\
\hline $11-25-70$ & --- & .38 & $4-21-74$ & --- & 1.9 & $11-30-77$ & --- & .07 & & & \\
\hline
\end{tabular}

ef Estimated. 
Table 40. Discharge measurements, in cubic feet per second,

of Ripu Stream, Yap (16892600)

Location: Lat $9^{\circ} 30^{\prime} 10^{\prime \prime} \mathrm{N}$. , long $138^{\circ} 06^{\prime} 24^{\prime \prime} \mathrm{E} ., 300 \mathrm{ft}$ upstream from mouth and $0.3 \mathrm{mi}$ southwest of Gitaem water-treatment plant at altitude 10

ft (from topographic map).

Drainage area: $0.29 \mathrm{mi}^{2}$.

Period of record: 1968-82.

\begin{tabular}{|c|c|c|c|c|c|c|c|c|c|c|c|}
\hline Date & & Discharge & Date & & Discharge & Date & & Discharge & Date & & ischarge \\
\hline $3-7-68$ & --- & 0.63 & $9-22-70$ & -- & 0.21 & $9-20-72$ & -- & 0.16 & $8-11-76$ & -- & 0.86 \\
\hline $7-29-68$ & -- & 3.5 & $10-7-70$ & -- & .16 & $10-12-72$ & -- & .04 & $10-10-76$ & -- & 0 \\
\hline $8-8-68$ & -- & .88 & $10-30-70$ & -- & .06 & $7-16-73$ & -- & .10 & $12-3-76$ & -- & .43 \\
\hline $9-4-68$ & -- & .61 & $11-13-70$ & -- & .16 & $2-17-74$ & -- & .39 & $1-21-77$ & -- & .16 \\
\hline $9-17-68$ & -- & .07 & $11-27-70$ & -- & .62 & $3-11-74$ & -- & .20 & $11-30-77$ & -- & .08 \\
\hline $10-17-68$ & $-\cdots$ & 3.3 & $12-22-70$ & -- & .09 & $4-21-74$ & -- & 1.8 & $12-30-77$ & -- & 0 \\
\hline $12-6-68$ & -- & .25 & $1-5-71$ & -- & .06 & $5-23-74$ & -- & 1.7 & $2-1-78$ & -- & .01 \\
\hline $6-14-69$ & -- & .50 & $1-26-71$ & -- & .12 & $6-14-74$ & -- & .19 & $3-16-78$ & -- & 0 \\
\hline $6-28-69$ & -- & .15 & $6-30-71$ & -- & .09 & $7-14-74$ & -- & .20 & $6-29-78$ & -- & .09 \\
\hline $9-19-69$ & -- & .43 & $7-6-71$ & -- & .10 & $9-13-74$ & -- & .21 & $7-25-78$ & -- & .01 \\
\hline $9-29-69$ & -- & 3.8 & $7-20-71$ & -- & .07 & $4-4-75$ & -- & 0 & $8-31-78$ & -- & .13 \\
\hline $10-16-69$ & -- & .19 & $7-27-71$ & -- & .13 & $5-2-75$ & -- & .22 & $10-30-78$ & -- & .11 \\
\hline $11-4-69$ & -- & .15 & $8-3-71$ & -- & .08 & $6-20-75$ & -- & 1.6 & $11-30-78$ & -- & .11 \\
\hline $11-20-69$ & -- & .07 & $9-17-71$ & -- & .40 & $7-15-75$ & -- & .85 & $12-28-78$ & -- & 0 \\
\hline $3-11-70$ & -- & 0 & $10-20-71$ & --- & .57 & $8-29-75$ & -- & .33 & $6-29-79$ & -- & 1.2 \\
\hline $3-24-70$ & -- & 0 & $12-3-71$ & -- & .04 & $10-9-75$ & -- & .17 & $8-21-79$ & -- & .14 \\
\hline $4-7-70$ & -- & 0 & $1-13-72$ & -- & .11 & $12-5-75$ & -- & .93 & $12-27-79$ & -- & .09 \\
\hline $4-29-70$ & -- & 0 & $3-23-72$ & -- & .34 & $1-9-76$ & -- & .07 & $9-17-80$ & -- & 1.5 \\
\hline $5-26-70$ & -- & 0 & $4-20-72$ & -- & .09 & $2-18-76$ & -- & $\underline{\mathrm{e}} / .01$ & $10-21-80$ & -- & .62 \\
\hline $7-14-70$ & -- & .10 & $5-18-72$ & --- & .004 & $4-2-76$ & -- & .84 & $7-17-81$ & --- & .43 \\
\hline $7-31-70$ & -- & .05 & $7-15-72$ & -- & .08 & $5-21-76$ & -- & .12 & $5-5-82$ & -- & .03 \\
\hline $9-2-70$ & -- & 3.3 & $8-10-72$ & -- & .22 & $7-2-76$ & -- & .09 & $6-17-82$ & -- & .73 \\
\hline
\end{tabular}

ef Est imated. 
Table 41. Discharge measurements, in cubic feet per second, of Dinaey Stream, Yap (16892650)

Location: Lat $9^{\circ} 30^{\prime} 32^{\prime \prime} \mathrm{N}$. , long $138^{\circ} 06^{\prime} 15^{\prime \prime} \mathrm{E}$, at upper Gitaem Reservoir, $0.4 \mathrm{mi}$ northwest of water-treatment plant and $1.5 \mathrm{mi}$ southwest of Colonia, at altitude $75 \mathrm{ft}$ (from topographic map).

Drainage area: $0.04 \mathrm{mi}^{2}$.

Period of record: 1980-82.

\begin{tabular}{ll}
\hline Date & Discharge \\
\hline $9-18-80$ & 0.14 \\
$10-21-80$ & .19 \\
$3-25-81$ & 0 \\
$4-8-81$ & 0 \\
$7-17-81$ & .06 \\
$5-5-82$ & .01 (estimated) \\
$6-17-82$ & \\
\hline
\end{tabular}


Table 42. Discharge measurements, in cubic feet per second, of Tholomar Stream, Yap (16892700)

Location: Lat $9^{\circ} 30^{\prime} 34^{\prime \prime} \mathrm{N}$. , long $138^{\circ} 06^{\prime} 21^{\prime \prime} \mathrm{E} ., 5 \mathrm{ft}$ upstream from confluence with Dinaey Stream and $1.4 \mathrm{mi}$ southwest of Colonia, at altitude $70 \mathrm{ft}$ (from topographic map). Site covered by water from new Gitaem dam since 1975. Reestablished in 1980 as station 16892680 at site $800 \mathrm{ft}$ upstream, at lat $9^{\circ} 30^{\prime} 37^{\prime \prime} \mathrm{N}$. , long $138^{\circ} 06^{\prime} 18^{\prime \prime} \mathrm{E}$., drainage area $0.10 \mathrm{mi}^{2}$, and altitude $75 \mathrm{ft}$ (from topographic map).

Drainage area: $0.13 \mathrm{mi}^{2}$.

Period of record: $1965,1968-74,1980-82$.

\begin{tabular}{|c|c|c|c|c|c|c|c|c|c|c|}
\hline Date & & Discharge & Date & & Discharge & Date & & Discharge & Date & Discharge \\
\hline $9-23-65$ & -- & 0.29 & $4-29-70$ & $\cdots$ & 0 & $7-6-71$ & -- & 0.15 & $2-17-74$ & $\ldots \quad 0.27$ \\
\hline $3-23-68$ & --- & .04 & $7-14-70$ & --- & .08 & $7-20-71$ & --- & .10 & $3-11-74$ & --- \\
\hline $8-8-68$ & -- & 1.0 & $7-30-70$ & -- & .74 & $7-21-71$ & -- & .15 & $4-21-74$ & ---2.6 \\
\hline $9-4-68$ & --- & 1.2 & $9-2-70$ & -- & 3.8 & $8-3-71$ & -- & .40 & & \\
\hline $10-17-68$ & -- & 5.6 & $9-23-70$ & -- & .26 & $10-21-71$ & --- & .27 & $9-18-80$ & --- \\
\hline $6-14-69$ & -- & .36 & $10-6-70$ & -- & .28 & $1-13-72$ & -- & .11 & $10-21-80$ & -- \\
\hline $6-27-69$ & -- & .12 & $10-29-70$ & -- & .11 & $4-20-72$ & -- & .09 & $3-25-81$ & $\cdots 0$ \\
\hline $9-19-69$ & -- & .52 & $11-13-70$ & -- & .22 & $5-18-72$ & -- & .01 & $4-8-81$ & $\cdots 0$ \\
\hline $9-30-69$ & -- & .64 & $11-27-70$ & -- & .70 & $7-15-72$ & -- & .06 & $7-23-81$ & -- \\
\hline $10-14-69$ & -- & .32 & $12-22-70$ & -- & .16 & $8-11-72$ & --- & .21 & $5-5-82$ & $\ldots 1 / .01$ \\
\hline $11-4-69$ & --- & .25 & $1-6-71$ & --- & .18 & $9-20-72$ & -- & .14 & $6-17-82$ & --- \\
\hline $3-24-70$ & --- & 0 & $1-27-71$ & -- & .10 & $10-13-72$ & -- & .03 & & \\
\hline $4-8-70$ & -- & 0 & $7-1-71$ & -- & 1.0 & $1-11-73$ & --- & .02 & & \\
\hline
\end{tabular}

1/ Estimated. 
Table 43. Discharge measurements, in cubic feet per second, of Mabuug Stream, Yap (16893050)

Location: Lat $9^{\circ} 31^{\prime} 14^{\prime \prime} \mathrm{N}$. , long $138^{\circ} 07^{\prime} 00^{\prime \prime} \mathrm{E}$, at Mabuuq, $0.4 \mathrm{mi}$ upstream from mouth and $0.9 \mathrm{mi}$ northwest of Ganiir bridge in Colonia, at altitude $45 \mathrm{ft}$ (from topographic map).

Drainage area: $0.30 \mathrm{mi}^{2}$.

Period of record: 1968-72.

\begin{tabular}{|c|c|c|c|c|c|c|c|}
\hline Date & & Discharge & Date & & Discharge & Date & Discharge \\
\hline $9-26-68$ & -- & 0.14 & $5-26-70$ & --- & 0 & $7-1-71 \cdots$ & 0.59 \\
\hline $10-16-68$ & $\cdots$ & 27 & $7-14-70$ & -- & .03 & $7-6-71 \cdots$ & .20 \\
\hline $6-14-69$ & -- & .20 & $7-30-70$ & -- & .08 & $7-19-71 \ldots$ & .22 \\
\hline $9-18-69$ & --- & .14 & $9-2-70$ & -- & 7.2 & $8-3-71=-$ & .58 \\
\hline $10-8-69$ & -- & .14 & $9-24-70$ & --- & 1.6 & $10-21-71 \ldots$ & .11 \\
\hline $11-4-69$ & --- & .37 & $10-7-70$ & -- & .12 & $1-14-72=-$ & .08 \\
\hline $11-20-69$ & -- & .11 & $10-29-70$ & -- & .36 & $3-25-72---$ & .17 \\
\hline $1-21-70$ & $\cdots$ & .42 & $11-13-70$ & -- & .16 & $4-21-72---$ & .01 \\
\hline $3-11-70$ & -- & 0 & $11-27-70$ & $\ldots$ & .60 & $6-16-72-\cdots$ & .51 \\
\hline $4-8-70$ & -- & 0 & $12-22-70$ & -- & .18 & $8-11-72-\cdots$ & .16 \\
\hline $4-29-70$ & $\cdots$ & 0 & $1-6-71$ & --- & .07 & $9-20-72 \ldots$ & .13 \\
\hline
\end{tabular}


Table 44. Discharge measurements, in cubic feet per second, of Monguch Stream, Gagil-Tamil (16893180)

Location: Lat $9^{\circ} 31^{\prime} 59^{\prime \prime} \mathrm{N}$. , long $138^{\circ} 09^{\prime} 57^{\prime \prime} \mathrm{E} ., 0.7 \mathrm{mi}$ northeast of Tamilang Elementary School and $1.0 \mathrm{mi}$ south of Coast Guard LORAN station, at altitude $20 \mathrm{ft}$ (from topographic map).

Drainage area: $0.18 \mathrm{mi}^{2}$.

Period of record: $1979-82$.

\begin{tabular}{|c|c|c|c|}
\hline Date & Discharge & Date & Discharge \\
\hline $5-3-79$ & $\cdots \cdots a n$ a $/ 0.02$ & $10-20-80-\cdots$ & 2.0 \\
\hline $5-5-79$ & 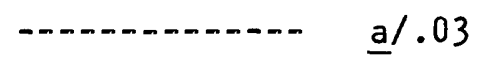 & $3-24-81-\ldots$ & .16 \\
\hline $5-7-79$ & $-\cdots-n-m-n-n$ & $4-7-81-\cdots-n-\cdots \cdots$ & .08 \\
\hline $5-11-79$ & 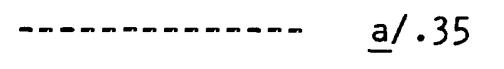 & $4-27-81 \quad \ldots-\ldots-n-1$ & .26 \\
\hline $5-15-79$ & 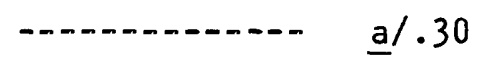 & $5-14-81-\ldots$ & .12 \\
\hline $5-29-79$ & $-m-n-m-n-m-n$ & $7-22-81-\ldots$ & 1.6 \\
\hline $5-30-79$ & $-\cdots-\cdots-m-\cdots$ & $5-6-82 \quad \cdots-\ldots$ & $\mathrm{b} / .08$ \\
\hline $6-4-79$ & $-\cdots-m-n-m-n$ & $6-15-82-\cdots-n-m-n$ & $\underline{b} / .20$ \\
\hline $7-25-79$ & $-\cdots-m-m-n-m$ & $9-16-82-\cdots$ & - 1.3 \\
\hline $9-16-80$ & 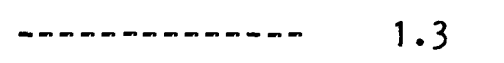 & & \\
\hline
\end{tabular}

a/ Measurements from Lyon Associates, 1980, made by V-notch weir and reported in gallons per minute.

b/ Measurements made near mouth at lat $9^{\circ} 32^{\prime} 03^{\prime \prime} \mathrm{N}$. , long $138^{\circ} 10^{\prime} 09^{\prime \prime} \mathrm{E}$. , altitude $5 \mathrm{ft}$ :

$$
\begin{aligned}
& 5-6-82 \\
& 6-15-82 \ldots \mathrm{ft}^{3} / \mathrm{s}
\end{aligned}
$$


Table 45. Discharge measurements, in cubic feet per second, of Gilaew Stream, Gagil-Tamil (16893310)

Location: Lat $9^{\circ} 32^{\prime} 12^{\prime \prime} \mathrm{N}$. , long $138^{\circ} 11^{\prime} 29^{\prime \prime} \mathrm{E}$, at road culvert, $0.3 \mathrm{mile}$ downstream from Gilaew Spring, $0.4 \mathrm{mi}$ upstream from mouth, and $0.45 \mathrm{mi}$ south of Gagil Elementary School, at altitude $15 \mathrm{ft}$ (from topographic map). Drainage area: $0.15 \mathrm{mi}^{2}$.

Period of record: $1968-80$.

\begin{tabular}{|c|c|c|c|c|c|c|c|c|c|c|c|}
\hline Date & & Discharge & Date & & Discharge & Date & & i scharge & Date & & ischarge \\
\hline $3-20-68$ & -- & 0.12 & $11-12-70$ & -. & 0.45 & $7-11-43$ & --- & $/ 0.02$ & $1-8-76$ & -- & 0.19 \\
\hline $8-19-68$ & -- & .27 & $11-25-70$ & -- & .54 & $3-7-74$ & -. & .13 & $2-18-76$ & -.- & .10 \\
\hline $10-4-68$ & $\ldots$ & .10 & $12-28-70$ & $\ldots$ & .14 & $4-19-74$ & $\ldots$ & .16 & $4-1-76$ & $\ldots$ & .11 \\
\hline $10-23-68$ & -.- & .25 & $1-6-71$ & -. & .15 & $5-7-74$ & $\ldots$ & .16 & $5-19-76$ & $\ldots$ & 1.7 \\
\hline $10-31-68$ & -- & .24 & $6-30-71$ & -- & 1.1 & $5-17-74$ & $-\cdots$ & .24 & $7-7-76$ & -- & .42 \\
\hline $11-19-68$ & -- & .16 & $7-8-71$ & -- & .27 & $6-5-74$ & -. & .78 & $8-9-76$ & -- & .71 \\
\hline $12-3-68$ & $\ldots$ & .31 & $7-19-71$ & -.- & .33 & $7-10-74$ & -. & .46 & $10-10-76$ & -. & .41 \\
\hline $1-7-69$ & -- & .10 & $7-27-71$ & -- & .73 & $8-16-74$ & -. & 1.2 & $12-2-76$ & $\cdots$ & .26 \\
\hline $2-10-69$ & -. & 0 & $8-3-71$ & -- & .30 & $9-12-74$ & $\ldots$ & .27 & $1-20-77$ & $\ldots$ & .10 \\
\hline $6-13-69$ & -- & e/.02 & $10-19-71$ & -- & .17 & $10-3-74$ & -- & .32 & $11-29-77$ & $\cdots$ & .13 \\
\hline $9-19-69$ & $\ldots$ & .36 & $1-14-72$ & $\ldots$ & .24 & $11-9-74$ & $\ldots$ & 1.4 & $12-29-77$ & -- & .13 \\
\hline $9-29-69$ & $\ldots$ & .46 & $2-24-72$ & $\ldots$ & .17 & $12-3-74$ & -. & .69 & $2-1-78$ & $\ldots$ & .07 \\
\hline $11-6-69$ & -- & .88 & $3-23-72$ & -- & .42 & $1-2-75$ & -- & .40 & $3-15-78$ & $\cdots$ & .06 \\
\hline $11-18-69$ & -.. & .32 & $4-21-72$ & -. & .10 & $2-13-75$ & $\ldots$ & .36 & $4-12-78$ & $\ldots$ & .02 \\
\hline $1-14-70$ & $\cdots$ & .24 & $5-18-72$ & $\ldots$ & .06 & $4-2-75$ & -- & .06 & $6-28-78$ & -- & .05 \\
\hline $1-29-70$ & -- & .20 & $6-16-72$ & -- & .08 & $4-30-75$ & -- & .29 & $7-21-78$ & $\ldots$ & .13 \\
\hline $8-31-70$ & -- & 1.2 & $7-15-72$ & -. & .13 & $5-20-75$ & -- & .19 & $8-30-78$ & -- & .11 \\
\hline $9-15-70$ & $\cdots$ & .15 & $8-10-72$ & -- & .48 & $7-8-75$ & -- & .80 & $10-26-78$ & $\cdots$ & .06 \\
\hline $9-29-70$ & -- & .19 & $9-18-72$ & -- & 2.0 & $8-27-75$ & -- & .36 & $11-28-78$ & -- & .14 \\
\hline $10-5-70$ & $\cdots$ & .35 & $10-12-72$ & -- & .39 & $10-7-75$ & -- & .64 & $12-27-78$ & $\ldots$ & .30 \\
\hline $10-30-70$ & -- & .38 & $1-9-73$ & -.. & .04 & $12-3-75$ & $\ldots$ & .20 & $12-27-79$ & -. & .18 \\
\hline
\end{tabular}

e/ Estimated. 
Table 46. Discharge measurements, in cubic feet per second, of Yanbilang Stream, Gagil-Tamil (16893350)

Location: Lat $9^{\circ} 32^{\prime} 45^{\prime \prime} \mathrm{N} .$, long $138^{\circ} 11^{\prime} 48^{\prime \prime} \mathrm{E} ., 250 \mathrm{ft}$ upstream from mouth and $0.3 \mathrm{mi}$ northeast of Gagil School, at altitude $5 \mathrm{ft}$ (from topographic map).

Drainage area: $0.03 \mathrm{mi}^{2}$.

Period of record: 1968-72.

\begin{tabular}{|c|c|c|c|c|c|c|c|}
\hline Date & & Discharge & Date & & Discharge & Date & Discharge \\
\hline $10-10-67$ & -- & 0.04 & $3-23-70$ & -- & 0 & $12-24-70=-$ & 0.02 \\
\hline $10-14-68$ & --- & 1.6 & $4-6-70$ & --- & 0 & $1-6-71=-$ & .21 \\
\hline $11-19-68$ & -- & 0 & $.4-21-70$ & --- & 0 & $1-26-71---$ & .01 \\
\hline $12-3-68$ & -- & .51 & $5-11-70$ & --- & 0 & $6-30-71--$ & .85 \\
\hline $1-7-69$ & -- & 0 & $8-31-70$ & --- & .71 & $7-8-71-\cdots$ & .28 \\
\hline $2-10-69$ & -- & 0 & $9-29-70$ & --- & .07 & $7-19-71--$ & .05 \\
\hline $4-18-69$ & --- & 0 & $10-7-70$ & --- & .04 & $7-27-71---$ & .80 \\
\hline $6-13-69$ & -- & $\underline{\mathrm{e}} / .01$ & $10-30-70$ & --- & .09 & $8-3-71---$ & .12 \\
\hline $10-15-69$ & -- & .02 & $11-12-70$ & --- & .12 & $10-19-71=-$ & .38 \\
\hline $11-6-69$ & -- & .12 & $11-25-70$ & --- & .05 & $2-25-72=-$ & .71 \\
\hline
\end{tabular}

e/ Estimated. 
Table 47. Discharge measurements, in cubic feet per second, of Qamin Stream, Maap (16893500)

Location: Lat $9^{\circ} 35^{\prime} 57^{\prime \prime} \mathrm{N}$. , long $138^{\circ} 10^{\prime} 15^{\prime \prime} \mathrm{E} ., 0.25 \mathrm{mi}$ southeast of Qamin and $0.8 \mathrm{mile}$ upstream from mouth at altitude $45 \mathrm{ft}$ (from topographic map).

Drainage area: $0.19 \mathrm{mi}^{2}$.

Period of record: 1980-81.

\begin{tabular}{|c|c|c|}
\hline Date & & Discharge \\
\hline $9-19-80$ & n-n-n-n & 0.49 \\
\hline $10-20-80$ & 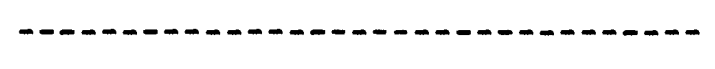 & 1.2 \\
\hline $3-24-81$ & 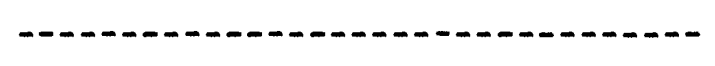 & .03 \\
\hline $4-8-81$ & 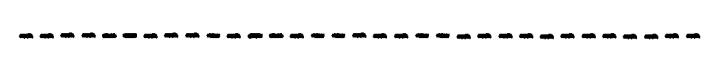 & 0 \\
\hline $7-18-81$ & 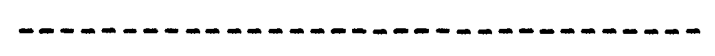 & .28 \\
\hline
\end{tabular}


Table 48. Discharge measurements, in cubic feet per second, made at miscellaneous sites

\begin{tabular}{|c|c|c|c|c|}
\hline \multirow[b]{2}{*}{ Stream } & \multirow{2}{*}{$\begin{array}{l}\text { Tribu- } \\
\text { tary to }\end{array}$} & \multirow[b]{2}{*}{ Location } & \multicolumn{2}{|c|}{ Measurement } \\
\hline & & & Date & Discharge \\
\hline Dalibaech & Pacific & Lat $9^{\circ} 30^{\prime} 32^{\prime \prime} \mathrm{N}$. , & $9-21-65$ & 0.19 \\
\hline Stream, Yap & Ocean & $\begin{array}{l}\text { long } 138^{\circ} 06^{\prime} 21^{\prime \prime} \mathrm{E} ., \\
\text { at inflow to reser- } \\
\text { voir, } 20 \mathrm{ft} \text { below } \\
\text { confluence of Tholomar } \\
\text { and Dinaey Streams, and } \\
1.4 \mathrm{mi} \text { southwest of } \\
\text { Colonia (Confluence } \\
\text { covered by water } \\
\text { from new Gitaem dam } \\
\text { since 1975). }\end{array}$ & $9-23-65$ & .46 \\
\hline Dorfay Stream, & Mukong & Lat $9^{\circ} 32^{\prime} 08^{\prime \prime} \mathrm{N}$. & $7-22-81$ & .93 \\
\hline Gagil-Tamil & Stream & long $138^{\circ} 10^{\prime} 13^{\prime \prime} \mathrm{E}$. , & $5-6-82$ & .12 \\
\hline$(16893190)$ & & at altitude $10 \mathrm{ft}$, & $6-15-82$ & .22 \\
\hline & & $\begin{array}{l}0.2 \mathrm{mi} \text { upstream from } \\
\text { mouth and } 0.9 \mathrm{mi} \text { north- } \\
\text { east of Tamilang School. }\end{array}$ & $9-16-82$ & .82 \\
\hline
\end{tabular}


Water Quality

Table 49. Chemical analyses of water from Qatliw (Atelu) Stream, Yap

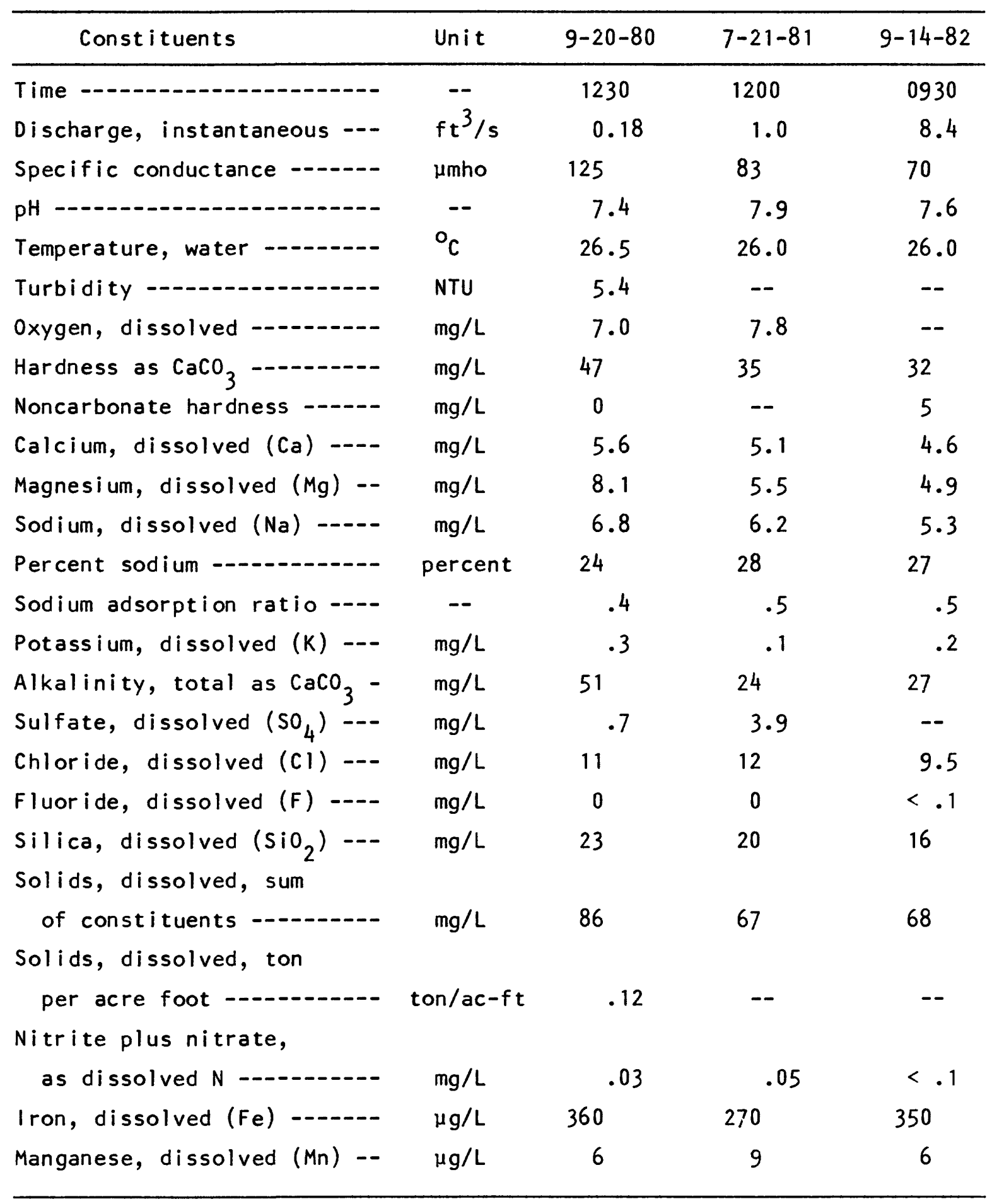


Table 50. Chemical analyses of water from Qaringeel (Aringel) Stream, Yap

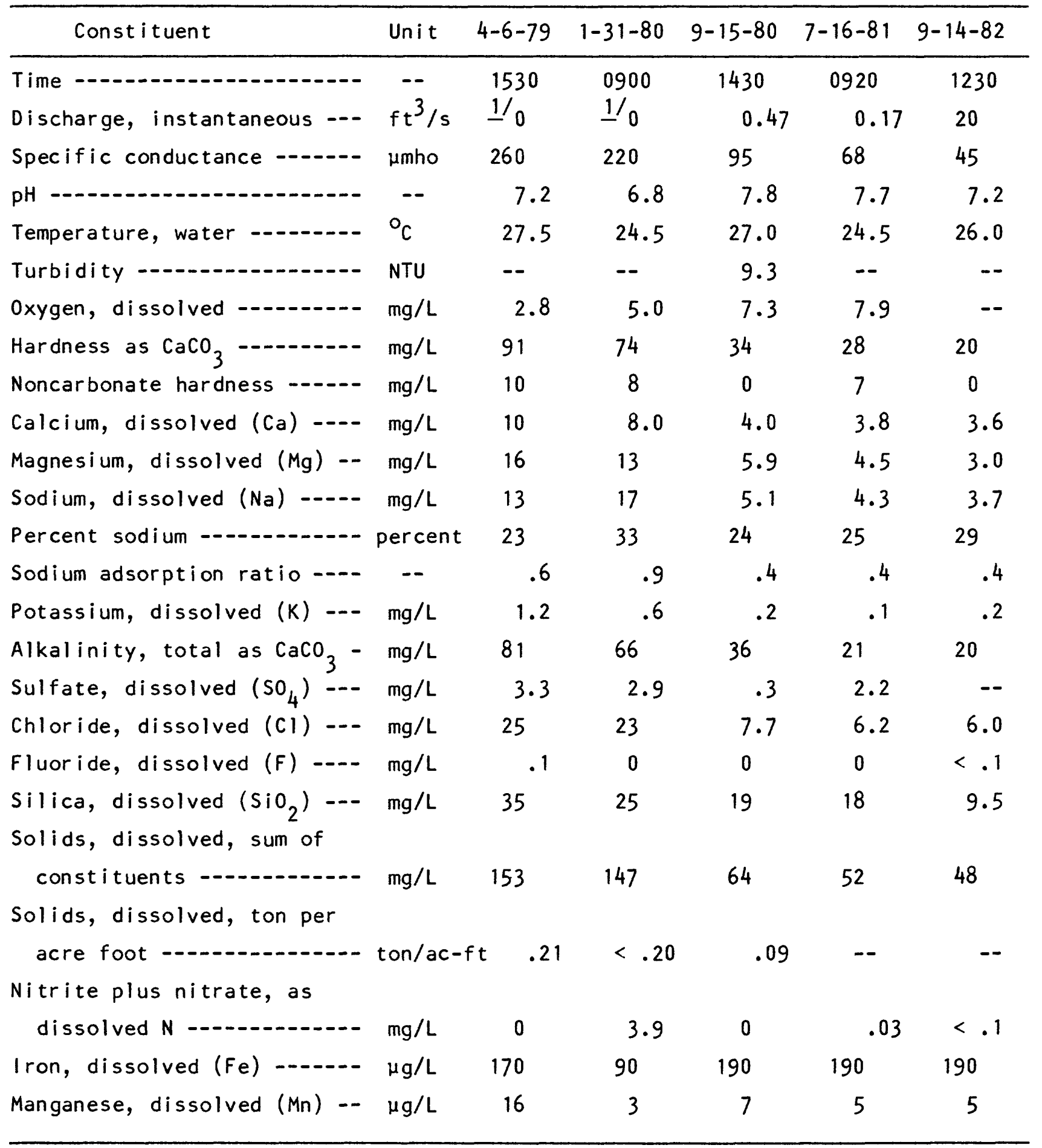

1/ Water sample taken from gage pool. 
Table 51. Chemical analyses of water from Daloelaeb (Dalolab) Stream, Yap.

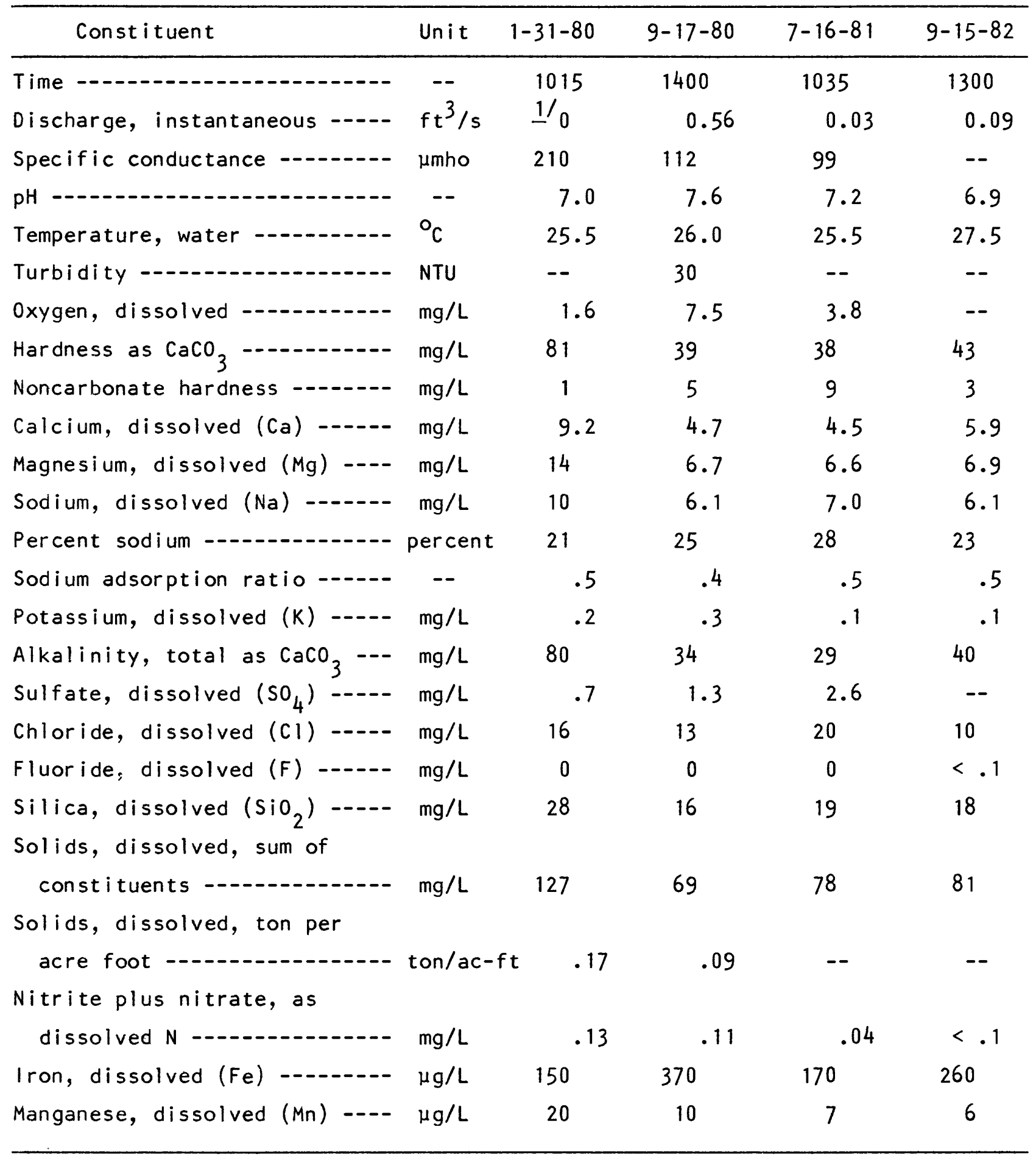

1/ Water sample taken from gage pool. 
Table 52. Chemical analyses of water from Peemgoy (Pemgoy) Stream, Yap

\begin{tabular}{|c|c|c|c|c|c|c|}
\hline Constituent & Unit & $4-7-79$ & $2-1-80$ & $9-17-80$ & $7-16-81$ & $9-15-82$ \\
\hline Time $-\cdots$ & -- & 1100 & 0915 & 1000 & 1235 & 0930 \\
\hline Discharge, instantaneous -..- & $\mathrm{ft}^{3} / \mathrm{s}$ & 0.01 & 0.01 & 0.27 & 0.08 & 0.68 \\
\hline Specific conductance & umho & 370 & 345 & 118 & 100 & -- \\
\hline 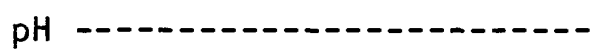 & -- & 7.5 & 7.5 & 7.5 & 7.6 & 7.4 \\
\hline Temperature, water & ${ }^{\circ} \mathrm{C}$ & 26.5 & 25.5 & 26.5 & 25.5 & 26.0 \\
\hline Turbidity & NTU & -- & -- & 8.4 & -- & -- \\
\hline Oxygen, dissolved - & $\mathrm{mg} / \mathrm{L}$ & 3.2 & 4.6 & 7.9 & 6.0 & -- \\
\hline Hardness as $\mathrm{CaCO}_{3}$ & $\mathrm{mg} / \mathrm{L}$ & 170 & 140 & 41 & 38 & 33 \\
\hline Noncarbonate hardness & $\mathrm{mg} / \mathrm{L}$ & 0 & 0 & 0 & 9 & 13 \\
\hline Calcium, dissolved ( $\mathrm{Ca}$ ) --- & $\mathrm{mg} / \mathrm{L}$ & 17 & 15 & 5.2 & 4.3 & 4.0 \\
\hline Magnesium, dissolved (Mg) -- & $\mathrm{mg} / \mathrm{L}$ & 30 & 25 & 6.9 & 6.5 & 5.7 \\
\hline Sodium, dissolved $(\mathrm{Na})$ & $\mathrm{mg} / \mathrm{L}$ & 14 & 13 & 6.3 & 6.8 & 5.6 \\
\hline Percent sodium & percent & 15 & 17 & 25 & 28 & 27 \\
\hline Sodium adsorption ratio ---- & -- & .5 & .5 & .4 & .5 & .5 \\
\hline Potassium, dissolved (K) --- & $\mathrm{mg} / \mathrm{L}$ & .4 & .5 & .4 & .1 & .1 \\
\hline Alkalinity, total as $\mathrm{CaCO}_{3}-$ & $\mathrm{mg} / \mathrm{L}$ & 170 & 150 & 54 & 29 & 20 \\
\hline Sulfate, dissolved $\left(\mathrm{SO}_{4}\right)$ & $\mathrm{mg} / \mathrm{L}$ & 3.3 & .4 & .2 & 2.0 & 10 \\
\hline Chloride, dissolved (Cl) & $\mathrm{mg} / \mathrm{L}$ & 12 & 14 & 10 & 17 & 8.7 \\
\hline Fluoride, dissolved (F) & $\mathrm{mg} / \mathrm{L}$ & .1 & 0 & 0 & 0 & $<.1$ \\
\hline $\begin{array}{l}\text { Silica, dissolved }\left(\mathrm{SiO}_{2}\right)-- \\
\text { Solids, dissolved, sum of }\end{array}$ & $\mathrm{mg} / \mathrm{L}$ & 61 & 51 & 18 & 22 & 20 \\
\hline Solids, dissolved, ton per & $\mathrm{mg} / \mathrm{L}$ & 241 & 210 & 79 & 77 & 69 \\
\hline Nitrite plus nitrate, as & ton/ac- $f t$ & .33 & .29 & .11 & -- & -- \\
\hline dissolved $N$ & $\mathrm{mg} / \mathrm{L}$ & .11 & .29 & 0 & .08 & .47 \\
\hline Iron, dissolved (Fe) & $\mu g / L$ & 130 & 260 & 150 & 130 & 350 \\
\hline Manganese, dissolved (Mn) -- & $\mu \mathrm{g} / \mathrm{L}$ & 50 & 30 & 10 & 4 & 5 \\
\hline
\end{tabular}


Table 53. Chemical analyses of water from Taalgum (Talagu) Stream, Yap

\begin{tabular}{|c|c|c|c|c|}
\hline Const ituent & Unit & $2-1-80$ & $9-17-80$ & $9-15-82$ \\
\hline Time & -- & 0830 & 1100 & 1000 \\
\hline Discharge, instantaneous - - & $f t^{3} / s$ & $1 / 0$ & 0.56 & 0.25 \\
\hline Specific conductance & umho & 134 & 112 & -- \\
\hline 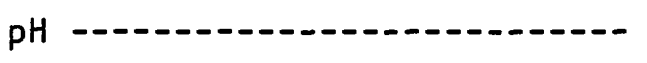 & -- & 6.6 & 7.1 & 7.0 \\
\hline Temperature, water & ${ }^{\circ} \mathrm{C}$ & $25 \cdot 5$ & 26.5 & 26.0 \\
\hline Turbidity - & NTU & -- & 6.9 & -- \\
\hline Oxygen, dissolved & $\mathrm{mg} / \mathrm{L}$ & 1.6 & 7.4 & -- \\
\hline Hardness as $\mathrm{CaCO}_{3}$ & $\mathrm{mg} / \mathrm{L}$ & 46 & 40 & 35 \\
\hline Noncarbonate hardness & $\mathrm{mg} / \mathrm{L}$ & 3 & 0 & 6 \\
\hline Calcium, dissolved ( $\mathrm{Ca}$ ) & $\mathrm{mg} / \mathrm{L}$ & 5.4 & 4.4 & 5.3 \\
\hline Magnesium, dissolved $(\mathrm{Mg}) \ldots$ & $\mathrm{mg} / \mathrm{L}$ & 7.8 & 7.0 & 5.4 \\
\hline Sodium, dissolved ( $\mathrm{Na}$ ) & $\mathrm{mg} / \mathrm{L}$ & 7.0 & 5.8 & 5.2 \\
\hline Percent sodium & percent & 25 & 24 & 24 \\
\hline Sodium adsorption ratio & -- & .5 & .4 & .4 \\
\hline Potassium, dissolved (K) & $\mathrm{mg} / \mathrm{L}$ & .1 & .4 & .1 \\
\hline Alkalinity, total as $\mathrm{CaCO}_{3} \ldots$ & $\mathrm{mg} / \mathrm{L}$ & 43 & 43 & 29 \\
\hline Sulfate, dissolved $\left(\mathrm{SO}_{4}\right) \ldots$ & $\mathrm{mg} / \mathrm{L}$ & .3 & .6 & -- \\
\hline Chloride, dissolved (Cl) & $\mathrm{mg} / \mathrm{L}$ & 14 & 11 & 8.5 \\
\hline Fluoride, dissolved (F) & $\mathrm{mg} / \mathrm{L}$ & 0 & 0 & $<.1$ \\
\hline Silica, dissolved $\left(\mathrm{SiO}_{2}\right)$ & $\mathrm{mg} / \mathrm{L}$ & 21 & 20 & 17 \\
\hline Solids, dissolved, sum of & 69 & & & \\
\hline constituents & $\mathrm{mg} / \mathrm{L}$ & 82 & 75 & 69 \\
\hline \multicolumn{5}{|l|}{ Solids, dissolved, ton per } \\
\hline acre foot & $\mathrm{ton} / \mathrm{ac}-\mathrm{ft}$ & .11 & .10 & -- \\
\hline \multicolumn{5}{|l|}{ Nitrite plus nitrate, as } \\
\hline dissolved $N$ & $\mathrm{mg} / \mathrm{L}$ & .16 & .01 & $<.1$ \\
\hline Iron, dissolved (Fe) & $\mu g / L$ & 30 & 140 & 270 \\
\hline Manganese, dissolved (Mn) $\ldots$ & $\mu \mathrm{g} / \mathrm{L}$ & 4 & 10 & 6 \\
\hline
\end{tabular}

$1 /$ Water sample taken from gage pool. 
Table 54. Chemical analyses of water from Burong Stream, Yap

\begin{tabular}{|c|c|c|c|c|c|}
\hline Constituent & Unit & $2-1-80$ & $9-18-80$ & $7-17-81$ & $9-17-82$ \\
\hline Time $-1-1-1-1$ & -- & 1645 & 1030 & 1520 & 0830 \\
\hline Discharge, instantaneous & $\mathrm{ft}^{3} / \mathrm{s}$ & $1 / 0$ & 2.0 & 1.3 & 0.14 \\
\hline Specific conductance & umho & 154 & 105 & 92 & 101 \\
\hline pH $-\cdots$ & -- & 7.0 & 7.1 & 7.3 & 7.0 \\
\hline Temperature, water & ${ }^{\circ} \mathrm{C}$ & 26.5 & 26.0 & 26.0 & 26.5 \\
\hline Turbidity & NTU & -- & 26 & -- & -- \\
\hline Oxygen, dissolved & $\mathrm{mg} / \mathrm{L}$ & -- & 7.4 & 6.5 & -- \\
\hline Hardness as $\mathrm{CaCO}_{3}$ & $\mathrm{mg} / \mathrm{L}$ & 55 & 39 & 37 & 43 \\
\hline Noncarbonate hardness & $\mathrm{mg} / \mathrm{L}$ & 3 & 0 & 7 & 3 \\
\hline Calcium, dissolved ( $\mathrm{Ca}$ ) ----- & $\mathrm{mg} / \mathrm{L}$ & 8.0 & 5.2 & 5.1 & 5.8 \\
\hline Magnesium, dissolved (Mg) -.-- & $\mathrm{mg} / \mathrm{L}$ & 8.4 & 6.2 & 6.0 & 7.0 \\
\hline Sodium, dissolved $(\mathrm{Na})$ & $\mathrm{mg} / \mathrm{L}$ & 7.3 & 5.6 & 6.3 & 5.4 \\
\hline Percent sodium & percent & 22 & 24 & 27 & 21 \\
\hline Sodium adsorption ratio & -- & .4 & .4 & .4 & .4 \\
\hline Potassium, dissolved (K) & $\mathrm{mg} / \mathrm{L}$ & .5 & .3 & .1 & .1 \\
\hline Alkalinity, total as $\mathrm{CaCO}_{3}$ & $\mathrm{mg} / \mathrm{L}$ & 52 & 43 & 30 & 40 \\
\hline Sulfate, dissolved $\left(\mathrm{SO}_{4}\right)$ & $\mathrm{mg} / \mathrm{L}$ & .4 & 1.1 & 3.1 & $<5$ \\
\hline Chloride, dissolved (Cl) - - & $\mathrm{mg} / \mathrm{L}$ & 13 & 8.2 & 9.0 & 8.1 \\
\hline Fluoride, dissolved (F) & $\mathrm{mg} / \mathrm{L}$ & 0 & 0 & 0 & $<.1$ \\
\hline $\begin{array}{l}\text { Silica, dissolved }\left(\mathrm{SiO}_{2}\right) \\
\text { Solids, dissolved, sum of }\end{array}$ & $\mathrm{mg} / \mathrm{L}$ & 20 & -- & 21 & 21 \\
\hline constituents & $\mathrm{mg} / \mathrm{L}$ & 94 & 60 & 69 & -- \\
\hline $\begin{array}{l}\text { Solids, dissolved, ton per } \\
\text { acre foot }\end{array}$ & $t o n / a c-f t$ & .13 & .08 & -- & -- \\
\hline Nitrite plus nitrate, as & & & & & \\
\hline dissolved N & $\mathrm{mg} / \mathrm{L}$ & 1.2 & .36 & .03 & .21 \\
\hline Iron, dissolved (Fe) & $\mu g / L$ & 60 & 380 & 260 & 81 \\
\hline Manganese, dissolved (Mn) ---- & $\mu g / L$ & 20 & 10 & 6 & 16 \\
\hline
\end{tabular}

1/ Water sample taken from gage pool. 
Table 55. Chemical analyses of water from Mukong Stream, Gagil-Tamil

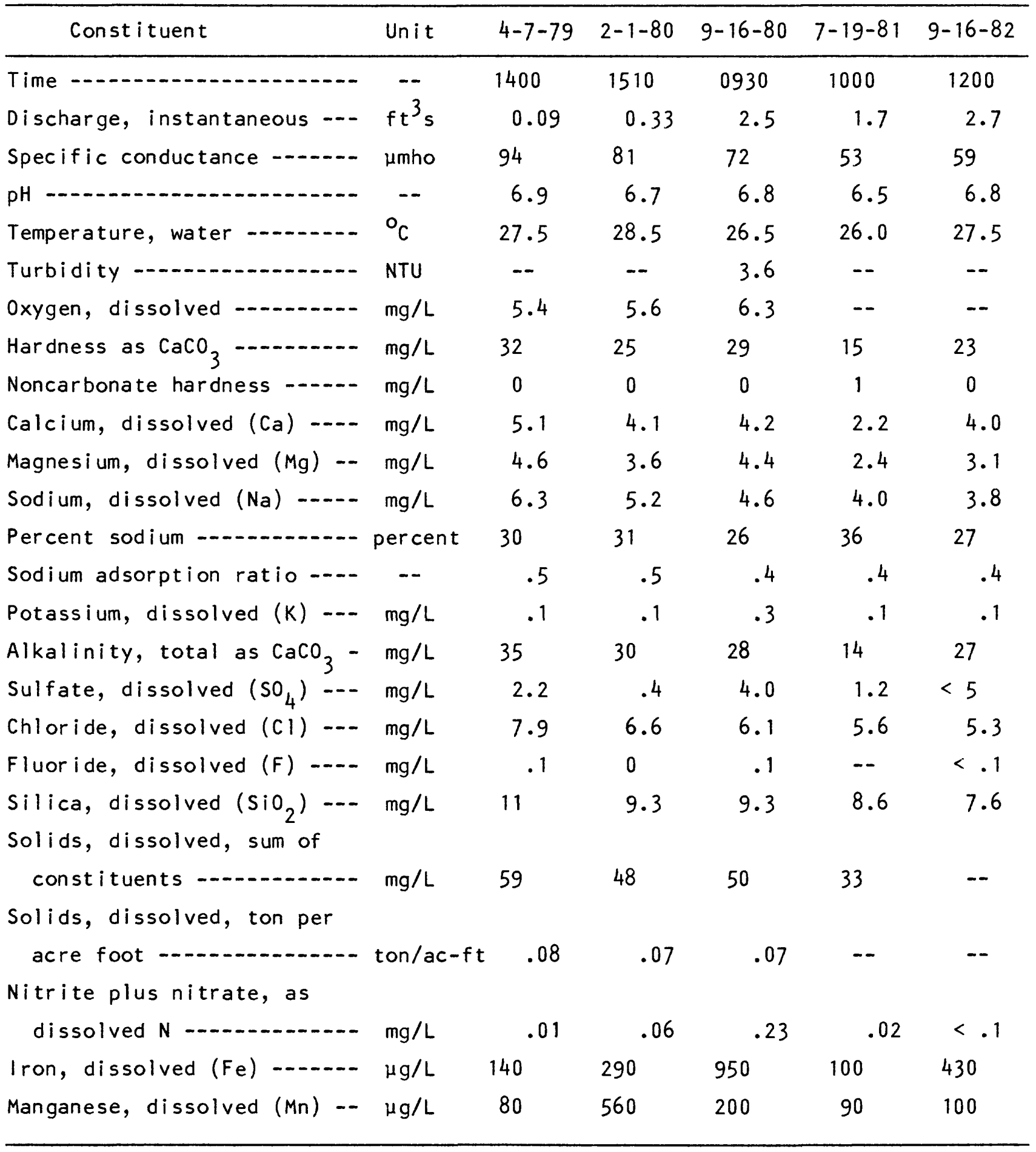


Table 56. Chemical analyses of water from Eyeb Stream, Gagil-Tamil

\begin{tabular}{|c|c|c|c|c|}
\hline Const ituent & Unit & $9-16-80$ & $7-18-81$ & $9-16-82$ \\
\hline Time & -- & 1130 & 1010 & 0915 \\
\hline Discharge, instantaneous -.. & $f t^{3} s$ & 1.9 & 2.2 & 2.5 \\
\hline Specific conductance & umho & 69 & 36 & 41 \\
\hline pH & -- & 6.8 & 6.8 & 6.9 \\
\hline Temperature, water & ${ }^{\circ} \mathrm{C}$ & 26.5 & 26.0 & 26.5 \\
\hline Turbidity & NTU & 1.4 & -- & -- \\
\hline Oxygen, dissolved & $\mathrm{mg} / \mathrm{L}$ & 6.9 & 7.2 & - \\
\hline Hardness as $\mathrm{CaCO}_{3}$ & $\mathrm{mg} / \mathrm{L}$ & 21 & 10 & 13 \\
\hline Noncarbonate hardness & $\mathrm{mg} / \mathrm{L}$ & 5 & 0 & 0 \\
\hline Calcium, dissolved $(\mathrm{Ca})$ & $\mathrm{mg} / \mathrm{L}$ & 5.6 & 2.1 & 2.7 \\
\hline Magnesium, dissolved (Mg) -- & $\mathrm{mg} / \mathrm{L}$ & 1.7 & 1.2 & 1.4 \\
\hline Sodium, dissolved ( $\mathrm{Na}$ ) & $\mathrm{mg} / \mathrm{L}$ & 4.1 & 4.0 & 3.6 \\
\hline Percent sodium & percent & 29 & 46 & 38 \\
\hline Sodium adsorption ratio -..- & -- & .4 & .5 & .5 \\
\hline Potassium, dissolved (K) -.- & $\mathrm{mg} / \mathrm{L}$ & .3 & .1 & .1 \\
\hline Alkalinity, total as $\mathrm{CaCO}_{3}-$ & $\mathrm{mg} / \mathrm{L}$ & 16 & 12 & 16 \\
\hline Sulfate, dissolved $\left(\mathrm{SO}_{4}\right) \ldots$ & $\mathrm{mg} / \mathrm{L}$ & 6.9 & .6 & $<5$ \\
\hline Chloride, dissolved (CI) --- & $\mathrm{mg} / \mathrm{L}$ & 6.0 & 5.2 & 5.3 \\
\hline Fluoride, dissolved (F) & $\mathrm{mg} / \mathrm{L}$ & 0 & 0 & $<.1$ \\
\hline $\begin{array}{l}\text { Silica, dissolved }\left(\mathrm{SiO}_{2}\right) \ldots- \\
\text { Solids, dissolved, sum }\end{array}$ & $\mathrm{mg} / \mathrm{L}$ & 7.2 & 7.6 & 6.0 \\
\hline $\begin{array}{l}\text { of constituents } \\
\text { Solids, dissolved, ton }\end{array}$ & $\mathrm{mg} / \mathrm{L}$ & 44 & 28 & -- \\
\hline $\begin{array}{l}\text { per acre foot } \\
\text { Nitrite plus nitrate, }\end{array}$ & ton/ac-ft & .06 & -- & -- \\
\hline as dissolved $\mathrm{N}$ & $\mathrm{mg} / \mathrm{L}$ & .43 & .02 & $<.1$ \\
\hline Iron, dissolved (Fe) & $\mu g / L$ & 390 & 160 & 120 \\
\hline Manganese, dissolved $(M n)$-- & $\mu g / L$ & 40 & 20 & 9 \\
\hline
\end{tabular}




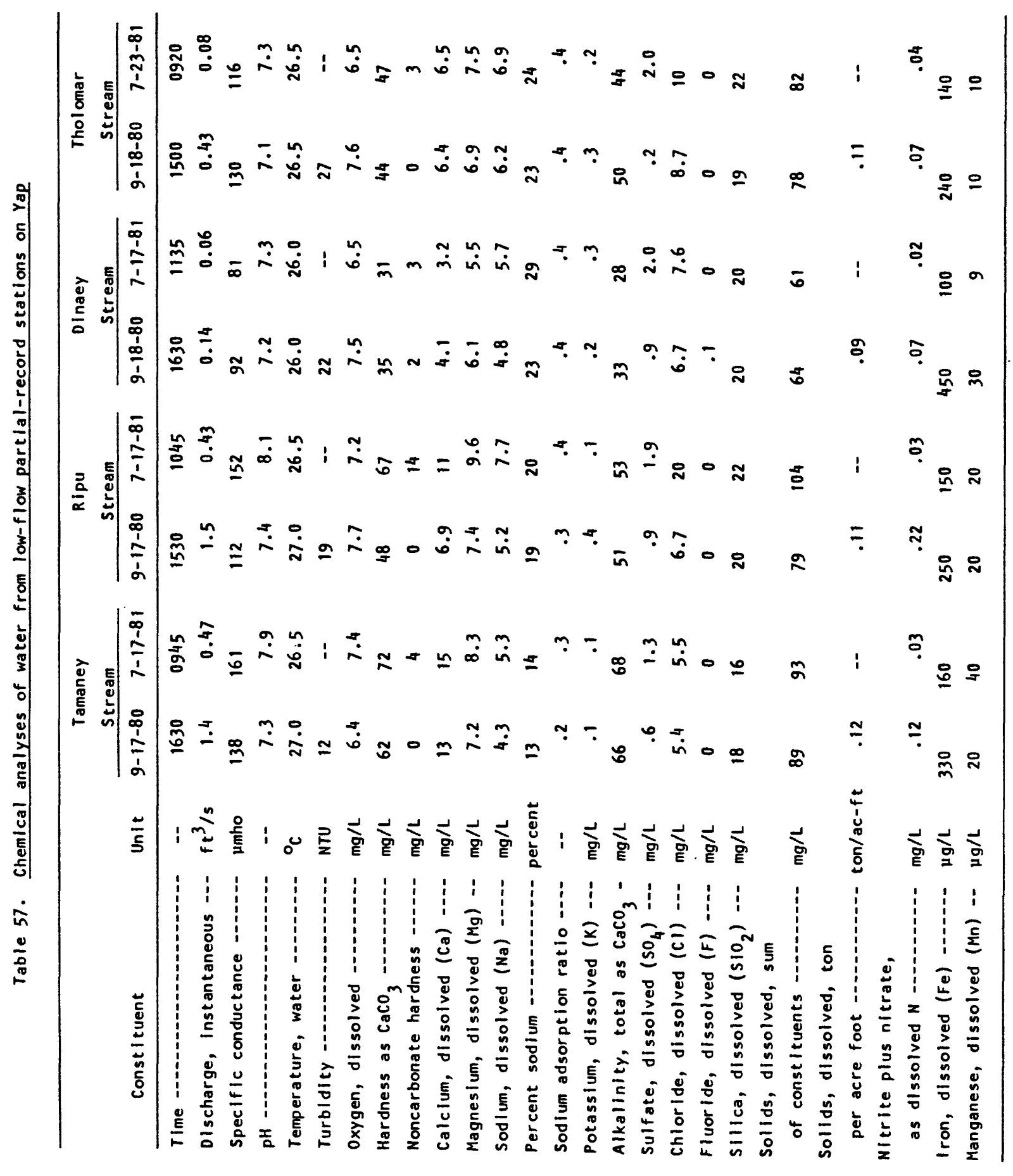




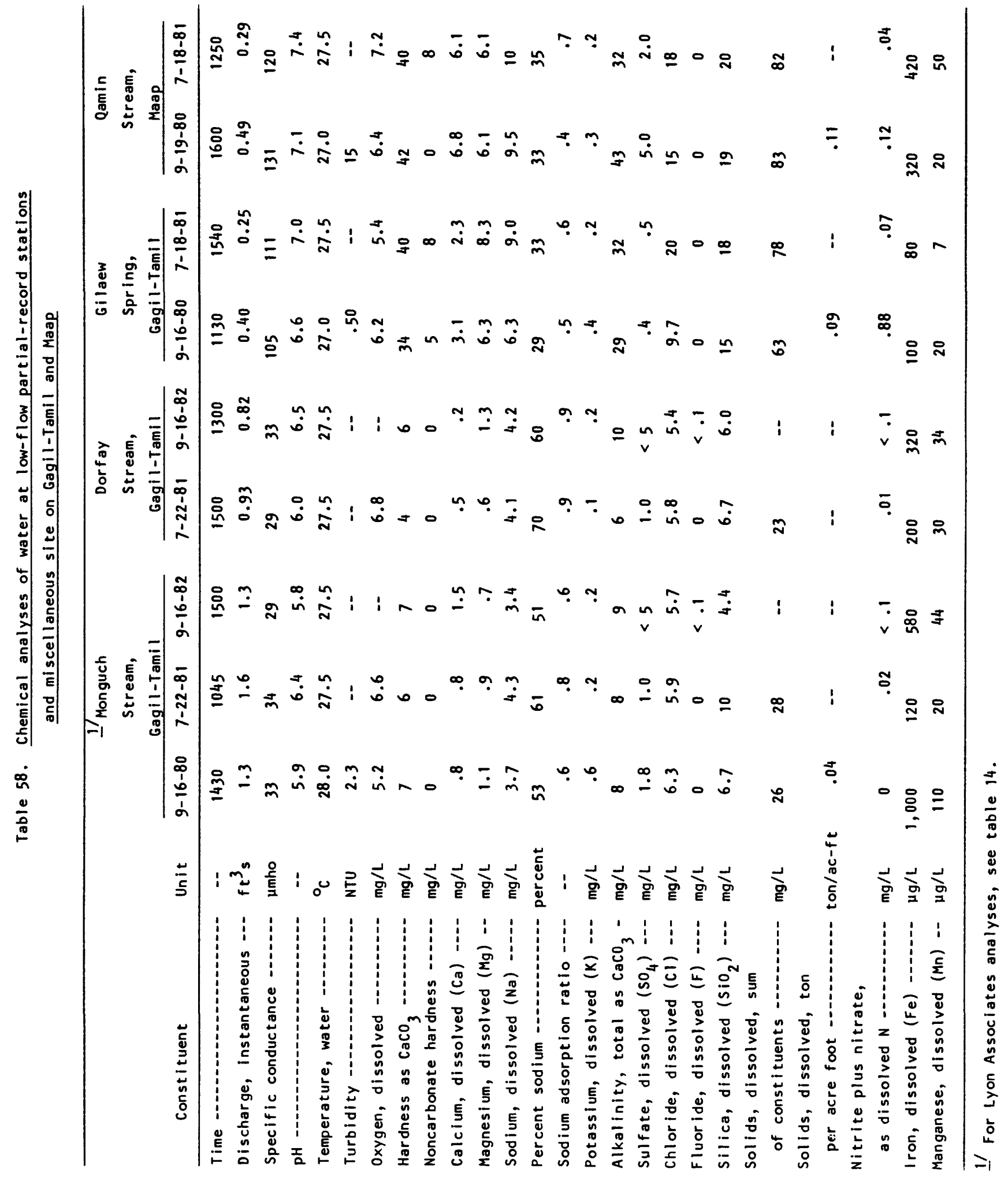


Table 59. Chemical analyses of water from Airport Swamp and Water Treatment Plant, Yap

\begin{tabular}{|c|c|c|c|c|c|c|}
\hline \multirow[b]{2}{*}{ Const i tuent } & \multirow[b]{2}{*}{ Unit } & \multicolumn{4}{|c|}{$\begin{array}{l}\text { 1/ Airport } \\
\text { Swamp }\end{array}$} & \multirow{2}{*}{$\begin{array}{l}2 / \text { Water } \\
\text { treatment } \\
\frac{p \text { lant }}{9-20-82}\end{array}$} \\
\hline & & $2-2-80$ & $9-20-80$ & $7-20-81$ & $9-15-82$ & \\
\hline 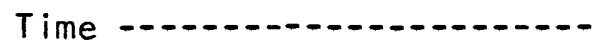 & -- & 0930 & 1030 & 1615 & 1520 & 1500 \\
\hline Specific conductance & $\mu \mathrm{mho}$ & 125 & 110 & 88 & -- & 145 \\
\hline 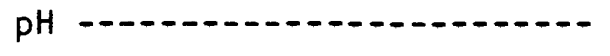 & -- & 7.7 & 7.3 & 8.5 & 7.6 & 7.2 \\
\hline Temperature, water & ${ }^{\circ} \mathrm{C}$ & 26.0 & 33.0 & 32.0 & 30.0 & -- \\
\hline Turbidity & NTU & -- & 15 & -- & -- & 60 \\
\hline Oxygen, dissolved & $\mathrm{mg} / \mathrm{L}$ & -- & 6.3 & 5.7 & -- & -- \\
\hline Hardness as $\mathrm{CaCO}_{3} \ldots$ & $\mathrm{mg} / \mathrm{L}$ & 41 & 43 & 36 & 41 & 56 \\
\hline Noncarbonate hardness & $\mathrm{mg} / \mathrm{L}$ & 1 & 2 & 8 & 1 & 13 \\
\hline Calcium, dissolved (Ca) & $\mathrm{mg} / \mathrm{L}$ & 13 & 14 & 12 & 13 & 14 \\
\hline Magnesium, dissolved (Mg) -- & $\mathrm{mg} / \mathrm{L}$ & 2.1 & 2.0 & 1.4 & 2.0 & 5.0 \\
\hline Sodium, dissolved ( $\mathrm{Na}$ ) & $\mathrm{mg} / \mathrm{L}$ & 5.5 & $4 \cdot 5$ & 2.3 & 3.9 & 5.6 \\
\hline Percent sodium & percent & 22 & 18 & 16 & 17 & 18 \\
\hline Sodium adsorption ratio & -- & .4 & .3 & .2 & .3 & .3 \\
\hline Potassium, dissolved (K) -.- & $\mathrm{mg} / \mathrm{L}$ & .5 & .7 & .8 & .5 & .5 \\
\hline Alkalinity, total as $\mathrm{CaCO}_{3}-$ & $\mathrm{mg} / \mathrm{L}$ & 40 & 41 & 28 & 40 & 43 \\
\hline Sulfate, dissolved $\left(\mathrm{SO}_{4}\right) \ldots$ & $\mathrm{mg} / \mathrm{L}$ & 4.7 & $3 \cdot 3$ & $<5$ & 6 & -- \\
\hline Chloride, dissolved $(\mathrm{Cl}) \ldots$ & $\mathrm{mg} / \mathrm{L}$ & 9.2 & 7.8 & 4.7 & 6.7 & 10 \\
\hline Fluoride, dissolved (F) $\ldots$ & $\mathrm{mg} / \mathrm{L}$ & 0 & .1 & 0 & $<.1$ & .1 \\
\hline $\begin{array}{l}\text { Silica, dissolved }\left(\mathrm{SiO}_{2}\right) \\
\text { Solids, dissolved, sum }\end{array}$ & $\mathrm{mg} / \mathrm{L}$ & 2.3 & 2.3 & 2.3 & 1.9 & 11 \\
\hline $\begin{array}{l}\text { of constituents } \\
\text { Solids, dissolved, ton }\end{array}$ & $\mathrm{mg} / \mathrm{L}$ & 61 & 61 & -- & 58 & 88 \\
\hline $\begin{array}{l}\text { per acre foot } \\
\text { Nitrite plus nitrate, }\end{array}$ & $\operatorname{ton} / a c-f t$ & .08 & .08 & -- & -- & .12 \\
\hline as dissolved $\mathrm{N}$ & $\mathrm{mg} / \mathrm{L}$ & .01 & .36 & .02 & $<.1$ & .12 \\
\hline Iron, dissolved (Fe) & $\mu g / L$ & 50 & 70 & 60 & 49 & 160 \\
\hline Manganese, dissolved $(M n)$-- & $\mu g / L$ & 9 & 10 & 40 & 11 & 30 \\
\hline
\end{tabular}

1/ Location: Lat $9^{\circ} 29^{\prime} 14^{\prime \prime} \mathrm{N}$. , long $138^{\circ} 05^{\prime} 06^{\prime \prime} \mathrm{E}$., altitude $33.6 \mathrm{ft}$, at old Yap airport. For 1967 analyses, see table 13.

2/ Finished water collected from rubber hose at plant. 


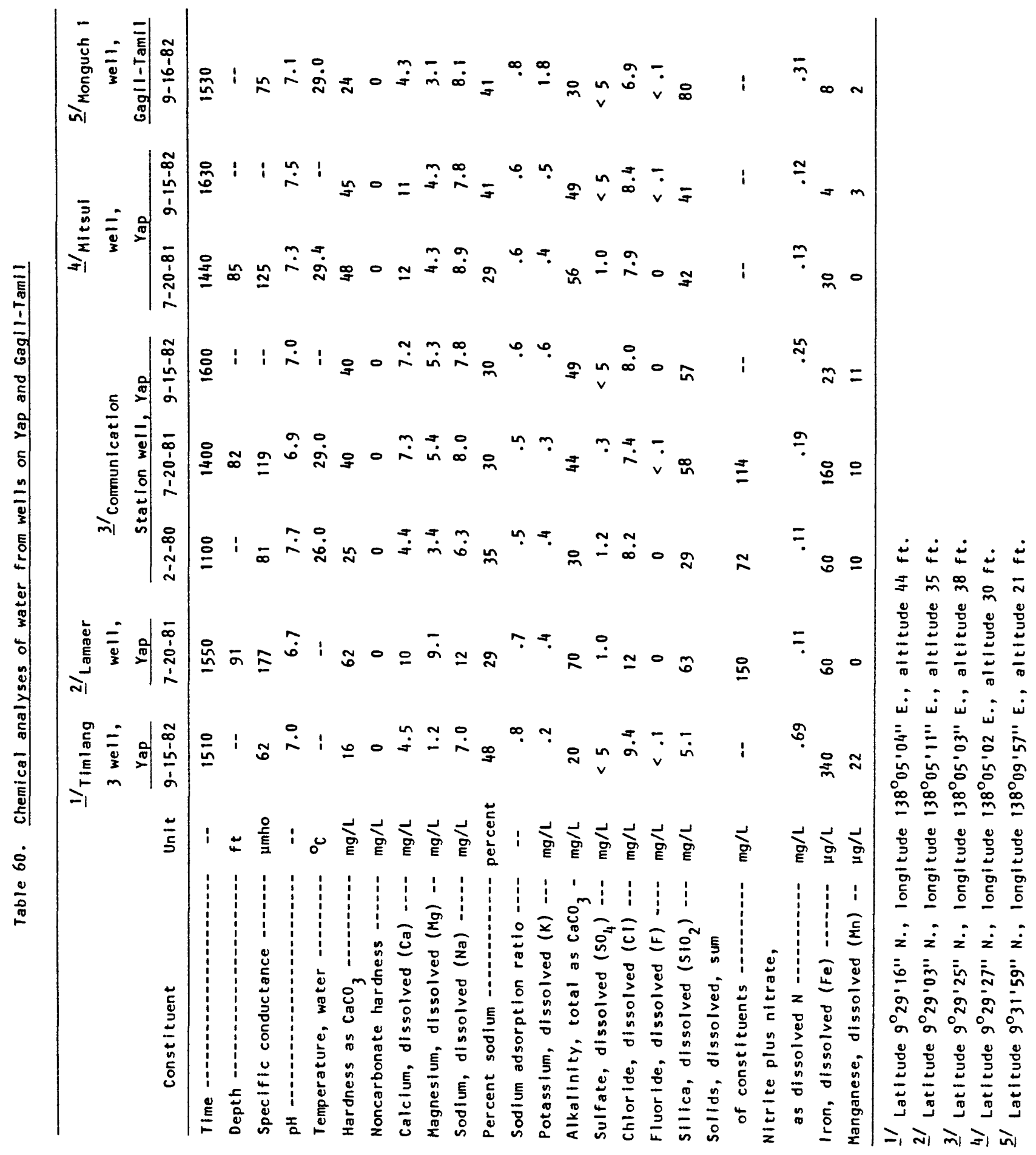


Table 61. Chemical analyses of water from Airport and Tamil aquifers (1982)

[Source: Nance, 1982. Samples analyzed by Brewer Analytical Laboratories, Honolulu, March 15-31, 1982]

\begin{tabular}{|c|c|c|c|c|}
\hline Constituent & Unit & $\begin{array}{c}\text { Timlang } 1 \\
\text { well, Yap } \\
2-20-82\end{array}$ & $\begin{array}{c}\text { Mukong Stream } \\
\text { well, } \\
\text { Gagi I-Tamil } \\
1-26-82\end{array}$ & $\begin{array}{c}\text { Monguch } 2 \\
\text { well, } \\
\text { Gagi I-Tamil } \\
1-30-82\end{array}$ \\
\hline pH $-\cdots$ & -- & 6.6 & 7.3 & 7.0 \\
\hline Turbidity & NTU & .2 & 3.9 & .5 \\
\hline Calcium & $\mathrm{mg} / \mathrm{L}$ & 2.4 & 1.2 & 2.1 \\
\hline Magnesi um - & $\mathrm{mg} / \mathrm{L}$ & 4.3 & 1.3 & 3.2 \\
\hline Sodium & $\mathrm{mg} / \mathrm{L}$ & 1.9 & 66.5 & 2.5 \\
\hline Potassium & $\mathrm{mg} / \mathrm{L}$ & .39 & 4.0 & 1.3 \\
\hline Chloride & $\mathrm{mg} / \mathrm{L}$ & 24 & 89 & 20 \\
\hline Fluoride & $\mathrm{mg} / \mathrm{L}$ & .35 & .64 & .35 \\
\hline Silica & $\mathrm{mg} / \mathrm{L}$ & 19 & 26 & 49 \\
\hline $\begin{array}{l}\text { Total dissolved } \\
\text { solids }\end{array}$ & $\mathrm{mg} / \mathrm{L}$ & 90 & 346 & 123 \\
\hline Nitrate & $\mathrm{mg} / \mathrm{L}$ & $<.19$ & $<.01$ & $<.01$ \\
\hline Arsenic & $\mathrm{mg} / \mathrm{L}$ & $<.002$ & $<.002$ & $<.002$ \\
\hline Barium - & $\mathrm{mg} / \mathrm{L}$ & $<.1$ & $<.1$ & $<.1$ \\
\hline Cadmium & $\mathrm{mg} / \mathrm{L}$ & $<.005$ & $<.005$ & $<.005$ \\
\hline Chromi um & $\mathrm{mg} / \mathrm{L}$ & $<.05$ & $<.05$ & $<.05$ \\
\hline Lead $\cdots$ & $\mathrm{mg} / \mathrm{L}$ & $<.05$ & $<.05$ & $<.05$ \\
\hline Mercury & $\mathrm{mg} / \mathrm{L}$ & .086 & .158 & .400 \\
\hline Selenium & $\mathrm{mg} / \mathrm{L}$ & $<.002$ & $<.002$ & $<.002$ \\
\hline Silver & $\mathrm{mg} / \mathrm{L}$ & $<.01$ & $<.01$ & $<.01$ \\
\hline
\end{tabular}

Note: For chemical analyses of Timlang 3 well, Yap, and Monguch 1 well, Gagil-Tamil, by U.S. Geological Survey, see table 60 . 
Table 62. Water and air temperatures and instantaneous discharge at Qatliw (Atelu) Stream, Yap

\begin{tabular}{|c|c|c|c|c|c|}
\hline Date & Time & & $\begin{array}{c}\text { Instanta- } \\
\text { neous } \\
\text { discharge } \\
\left(\mathrm{ft}^{3} / \mathrm{s}\right)\end{array}$ & $\begin{array}{c}\text { Tempera- } \\
\text { ture } \\
\text { water } \\
\left({ }^{\circ} \mathrm{C}\right)\end{array}$ & $\begin{array}{c}\text { Tempera- } \\
\text { ture } \\
\text { air } \\
\left({ }^{\circ} \mathrm{C}\right)\end{array}$ \\
\hline $\begin{array}{l}\text { Sept. } 20,1980 \\
\text { Oct. } 21,1980 \\
\text { July } 21,1981 \\
\text { Feb. 12, } 1982 \\
\text { Mar. } 25,1982 \\
\text { July } 14,1982 \\
\text { Sept. } 14,1982\end{array}$ & $\begin{array}{l}1235 \\
1210 \\
1200 \\
1140 \\
1115 \\
1305 \\
0940\end{array}$ & - & 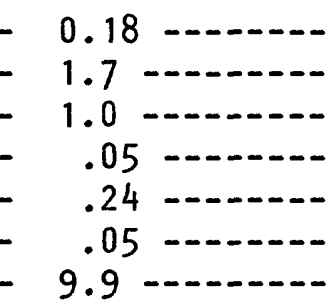 & $\begin{array}{l}26.5 \\
26.0 \\
26.0 \\
25.5 \\
25.5\end{array}$ & $\begin{array}{l}27.5 \\
27.0 \\
26.5 \\
27.5 \\
27.5\end{array}$ \\
\hline
\end{tabular}

Table 63. Water and air temperatures and instantaneous discharge at Qaringeel (Aringel) Stream, Yap

\begin{tabular}{|c|c|c|c|c|c|}
\hline Date & Time & & $\begin{array}{c}\text { Instanta- } \\
\text { neous } \\
\text { discharge } \\
\left(\mathrm{ft}^{3} / \mathrm{s}\right)\end{array}$ & $\begin{array}{c}\text { Tempera- } \\
\text { ture } \\
\text { water } \\
\left({ }^{\circ} \mathrm{C}\right)\end{array}$ & $\begin{array}{c}\text { Tempera- } \\
\text { ture } \\
\text { air } \\
\left({ }^{\circ} \mathrm{C}\right)\end{array}$ \\
\hline $\begin{array}{l}\text { Sept. } 18,1969 \\
\text { Oct. } 14,1969 \\
\text { Oct. } 30,1969 \\
\text { Nov. } 13,1969 \\
\text { Nov. } 25,1969 \\
\text { Dec. } 2,1969 \\
\text { Dec. } 18,1969 \\
\text { Jan. } 6,1970 \\
\text { Jan. } 22,1970 \\
\text { Feb. } 3,1970 \\
\text { Feb. } 24,1970 \\
\text { May } 11,1970 \\
\text { July } 14,1970 \\
\text { Oct. } 2,1970 \\
\text { Oct. } 13,1970 \\
\text { Oct. } 29,1970 \\
\text { Nov. } 9,1970 \\
\text { Nov. } 24,1970 \\
\text { Dec. } 16,1970 \\
\text { Dec. } 18,1970 \\
\text { Jan. } 8,1971 \\
\text { Jan. } 26,1971 \\
\text { Feb. } 8,1971\end{array}$ & $\begin{array}{l}0850 \\
0930 \\
1230 \\
1400 \\
0920 \\
1550 \\
1045 \\
0935 \\
1330 \\
1310 \\
0935 \\
0955 \\
1400 \\
1405 \\
1100 \\
1400 \\
1415 \\
1015 \\
1410 \\
1510 \\
1115 \\
1400 \\
1345\end{array}$ & 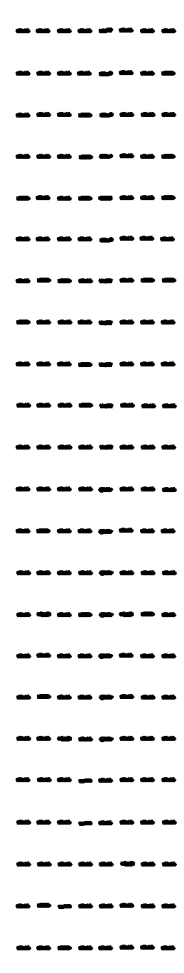 & 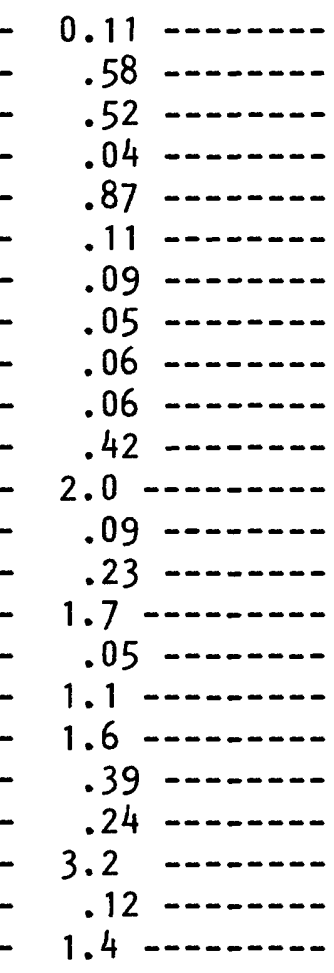 & $\begin{array}{l}24.0 \\
-\quad 26.0 \\
25.5 \\
-\quad 25.5 \\
25.5 \\
-\quad 25.5 \\
26.0 \\
-\quad 24.0 \\
25.0 \\
-\quad 26.0 \\
26.0 \\
26.0 \\
-26.0 \\
27.0 \\
26.0 \\
26.0 \\
-\quad 26.0 \\
26.0 \\
26.0 \\
27.0 \\
\\
25.0 \\
\end{array}$ & \\
\hline
\end{tabular}


Table 63. Water and air temperatures and instantaneous discharge at Qaringeel (Aringel) Stream, Yap--Continued

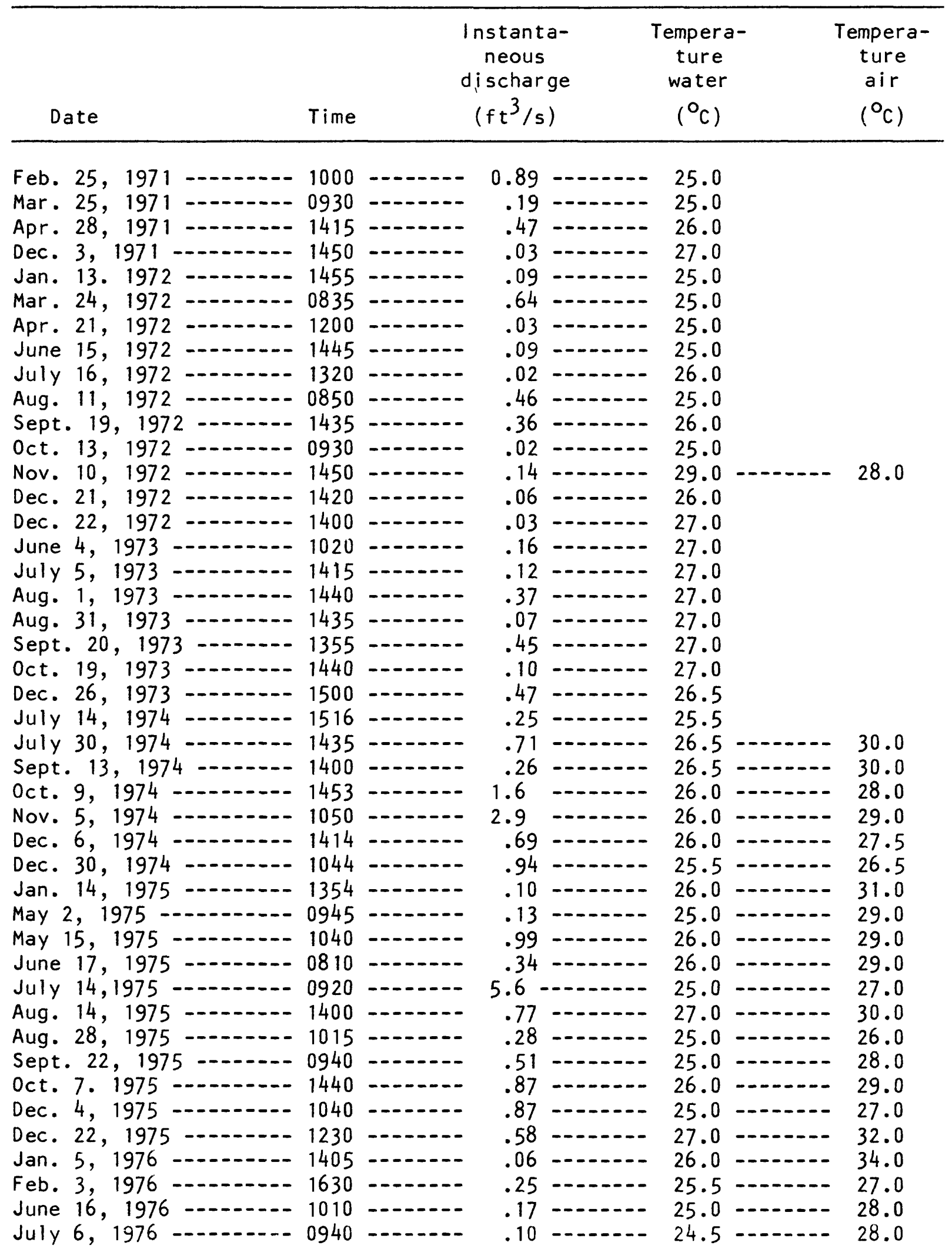


Table 63. Water and air temperatures and instantaneous discharge at Qaringeel (Aringel) Stream, Yap--Continued

\begin{tabular}{|c|c|c|c|c|c|c|c|}
\hline Date & Time & & $\begin{array}{r}\text { Instant } \\
\text { neous } \\
\text { dischar } \\
\left(\mathrm{ft}^{3} / \mathrm{s}\right.\end{array}$ & & $\begin{array}{c}\text { Tempera } \\
\text { ture } \\
\text { water } \\
\left({ }^{\circ} \mathrm{C}\right)\end{array}$ & & $\begin{array}{c}\text { Tempera- } \\
\text { ture } \\
\text { air } \\
\left({ }^{\circ} \mathrm{C}\right)\end{array}$ \\
\hline July $26,1976 \ldots$ & 1400 & ----- & 0.73 & & 26.0 & -- & 27.0 \\
\hline Aug. $10,1976 \ldots$ & 1520 & $\cdots-\cdots$ & .20 & & 26.0 & & 27.5 \\
\hline Aug. $26,1976 \ldots$ & 1415 & $-\cdots$ & .76 & $-\cdots$ & 25.0 & $-\cdots$ & 27.5 \\
\hline Sept. $16,1976 \ldots$ & 1320 & $-\cdots-\cdots$ & .48 & $-\cdots-n$ & 26.0 & $-\cdots-n$ & 30.0 \\
\hline Nov. $2,1976 \ldots$ & 1500 & $\ldots-\ldots$ & .13 & $\ldots \ldots$ & 27.0 & $-\cdots$ & 29.5 \\
\hline Dec. $2,1976 \ldots$ & 1235 & $-\cdots-\cdots$ & .51 & $-\ldots-\ldots$ & 25.0 & $-\ldots-n$ & 27.5 \\
\hline Dec. 29, 1976 & 1510 & $\cdots-\cdots$ & 1.7 & 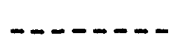 & 27.0 & 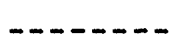 & 29.0 \\
\hline Jan. $21,1977 \ldots$ & 0950 & $-\cdots-\cdots$ & .36 & $--\cdots--$ & 24.0 & $-\cdots-\cdots$ & $25 \cdot 5$ \\
\hline May $31,1977 \ldots$ & 1500 & $---\cdots$ & .08 & $\ldots-n$ & 26.0 & $-\cdots---$ & 28.0 \\
\hline June $30,1977 \ldots$ & 1515 & $-\cdots-\cdots$ & .06 & 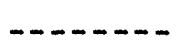 & 26.0 & $-\ldots-n$ & 30.0 \\
\hline Aug. 12,1977 & 1350 & $-\cdots-\cdots$ & .07 & $--\cdots-\cdots$ & 28.0 & $--\cdots---$ & 31.0 \\
\hline Nov. 1,1977 & 1350 & $\cdots \cdots-\cdots$ & .01 & $-\cdots-\cdots$ & 26.0 & $\cdots-\cdots$ & 32.5 \\
\hline Nov. 29, $1977 \ldots$ & 1400 & $-\cdots-\cdots$ & .09 & $---\ldots$ & 26.0 & $--\cdots-.-$ & 30.5 \\
\hline Dec. $15,1977 \ldots$ & 1450 & 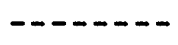 & 1.8 & $\cdots-\cdots$ & 26.0 & $\cdots \cdots$ & 28.5 \\
\hline Dec. $30,1977 \ldots$ & 0930 & $\cdots-\cdots$ & .01 & $\cdots-\cdots$ & 25.0 & $\cdots \cdots$ & 27.0 \\
\hline Feb. $1,1978 \ldots$ & 1350 & $-\cdots-\cdots$ & .04 & $-\cdots-\cdots$ & 25.5 & $-\cdots-\cdots$ & 27.0 \\
\hline June $15,1978 \ldots$ & 1415 & $-\cdots \cdots$ & .06 & 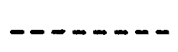 & 26.5 & 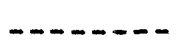 & 30.0 \\
\hline June $28,1978 \ldots$ & 1430 & $-\cdots-\cdots$ & .05 & $-\cdots-\cdots$ & 26.5 & 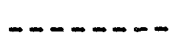 & 30.5 \\
\hline July $21,1978 \ldots$ & 1355 & $-\cdots-\cdots-\cdot$ & .03 & $---\cdots--$ & 27.0 & $---n--$ & 30.5 \\
\hline Aug. $30,1978 \ldots$ & 1515 & 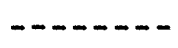 & .07 & $---\cdots-$ & 28.0 & $-\ldots-n$ & 30.0 \\
\hline Sept. 19, $1978 \ldots$ & 0935 & $-\cdots-n$ & .31 & 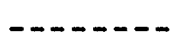 & 25.5 & 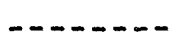 & 28.0 \\
\hline Sept. $29,1978 \ldots$ & 0910 & $-\cdots---$ & .30 & $-\cdots--$ & 26.0 & $-\cdots-\cdots$ & 28.0 \\
\hline Oct. $26,1978 \ldots$ & 1505 & $--\cdots--$ & .17 & $-\cdots-\cdots$ & 26.5 & $-\cdots-1-$ & 32.0 \\
\hline Nov. $9,1978 \ldots$ & 1440 & $-\cdots-\cdots$ & .49 & $-\cdots-n-$. & 26.0 & 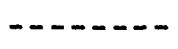 & 30.0 \\
\hline Nov. $28,1978 \ldots$ & 1410 & $\cdots \cdots \cdots$ & .07 & 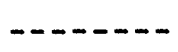 & 26.0 & 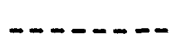 & 30.5 \\
\hline Dec. $13,1978 \ldots$ & 0935 & $\cdots-\cdots$ & 3.7 & $\cdots-\cdots$ & 25.5 & 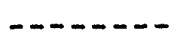 & 26.5 \\
\hline Mar. 15, 1979 & 1330 & $\cdots-\cdots--$ & .29 & $\cdots \cdots-\cdots$ & 26.5 & $-\ldots-n$ & 35.0 \\
\hline May 15,1979 & 1505 & ------ & .16 & $---\cdots--$ & 27.0 & $\cdots-\cdots$ & 32.0 \\
\hline June 13,1979 & 0855 & $\cdots-\cdots$ & .53 & $-\cdots-\cdots$ & 25.5 & $\cdots-\cdots$ & 26.5 \\
\hline June 27,1979 & 0915 & 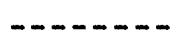 & 1.1 & $---n--$ & 26.0 & $\cdots-\cdots$ & 26.5 \\
\hline July $11,1979 \ldots$ & 1200 & $-\cdots-\cdots$ & 2.3 & $\ldots \ldots$ & 26.5 & 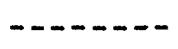 & 29.0 \\
\hline July $26,1979 \ldots$ & 1020 & $---\cdots$ & 1.7 & $-\cdots-n$ & 25.5 & $-\cdots-n$ & 26.5 \\
\hline Aug. $8,1979 \ldots$ & 0915 & $-\cdots-n$ & .54 & $---\cdots-$ & 25.5 & $-\ldots-n$ & 27.5 \\
\hline Aug. $21,1979 \ldots$ & 0945 & $-\cdots-\cdots-\cdot$ & .16 & $---\cdots--$ & 25.5 & $--\cdots-n$ & 28.5 \\
\hline oct. $15,1979 \ldots$ & 1445 & $\cdots-\cdots--$ & .12 & $\cdots-\cdots$ & 27.0 & $\cdots-\cdots-\cdots$ & 29.0 \\
\hline Oct. $30,1979 \ldots$ & 1400 & $\cdots-\cdots$ & .12 & $-\cdots-n$ & 26.0 & 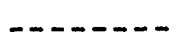 & 29.0 \\
\hline Dec. $26,1979 \ldots$ & 1010 & $-\cdots-\cdots$ & .21 & $-\cdots-\cdots$ & 25.0 & 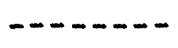 & 27.0 \\
\hline May $19,1980 \ldots$ & 1025 & $--\cdots-$. & .07 & 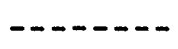 & 26.0 & $--\cdots-$. & 27.5 \\
\hline June $3,1980 \ldots$ & 1405 & $-\cdots-\cdots$ & .17 & $\cdots-\cdots$ & 26.5 & $-\cdots-\cdots$ & 30.0 \\
\hline June $30,1980 \ldots$ & 1030 & 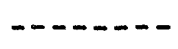 & .35 & 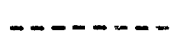 & 25.5 & $\ldots-n$ & 27.5 \\
\hline July $24,1980 \ldots$ & 0900 & $-\cdots-\cdots$ & .26 & 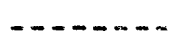 & 25.0 & $---n-$. & 25.5 \\
\hline July $31,1980 \ldots$ & 1055 & $-\ldots-n$ & .06 & 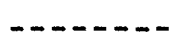 & 25.5 & 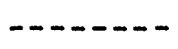 & 30.0 \\
\hline Sept. $2,1980 \ldots$ & 0940 & 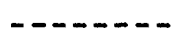 & .07 & $\cdots-\cdots-\cdots$ & 25.5 & $-\cdots-\cdots$ & 27.0 \\
\hline Sept. $15,1980 \ldots$ & 1430 & $\cdots-\cdots$ & .47 & $-\cdots-\cdots-\cdot$ & 27.0 & $--\cdots--$ & 30.0 \\
\hline
\end{tabular}


Table 64. Water temperature and instantaneous discharge at Faraq (Fara) Swamp out lets, Yap

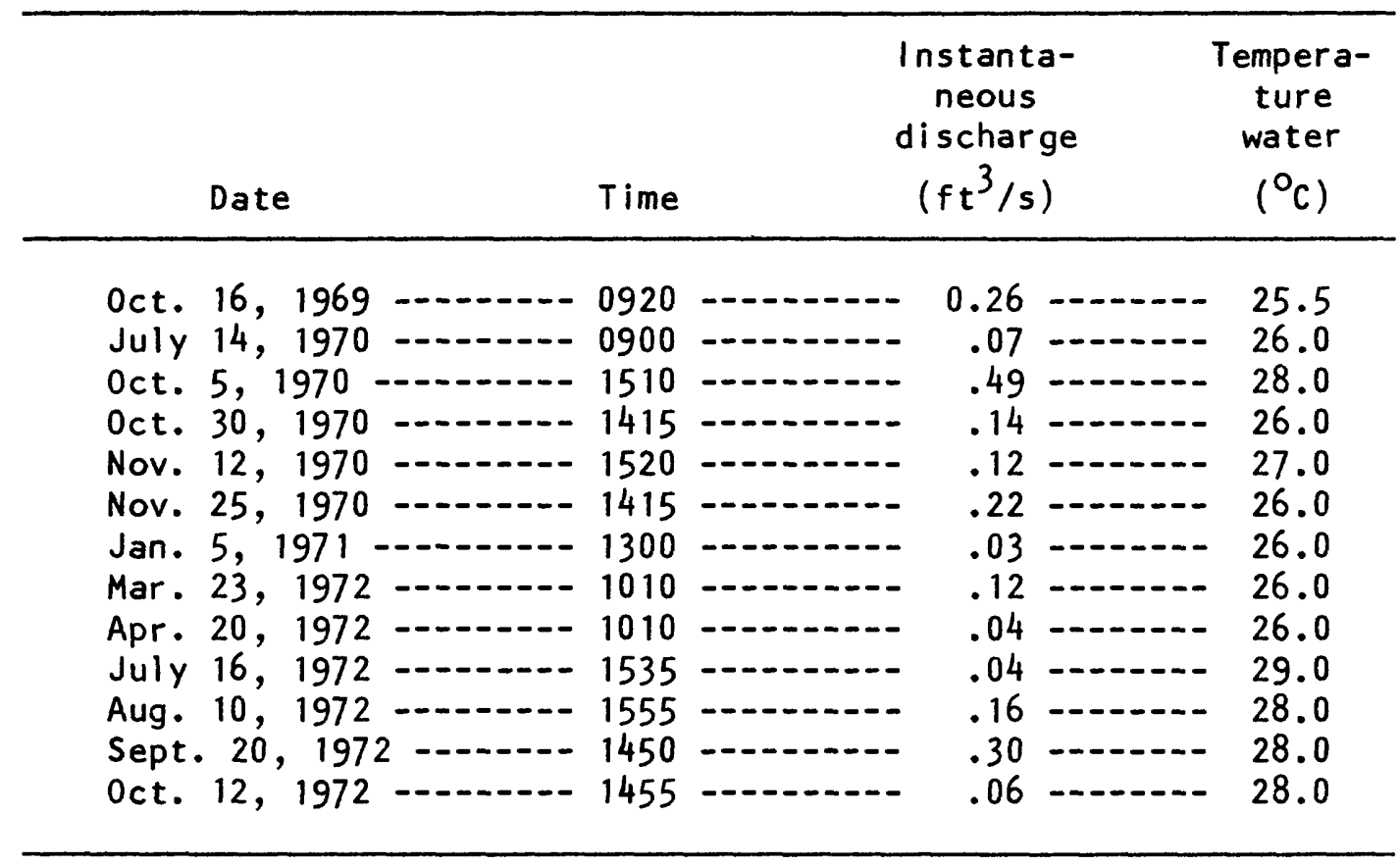

Table 65. Water temperature and instantaneous discharge at Galngun Swamp outlet, Yap

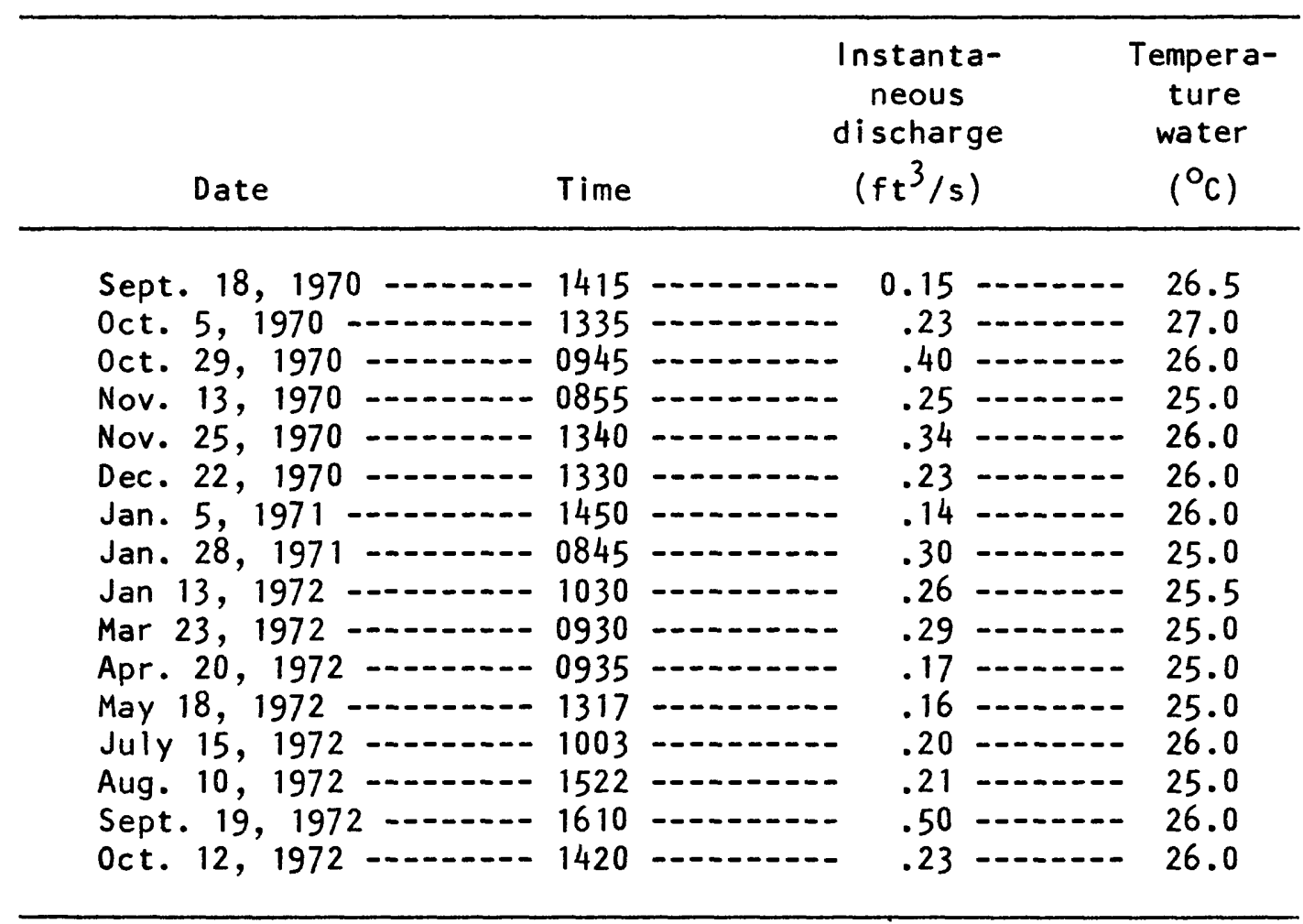


Table 66. Water and air temperatures and instantaneous discharge at Tamaney Stream, Yap

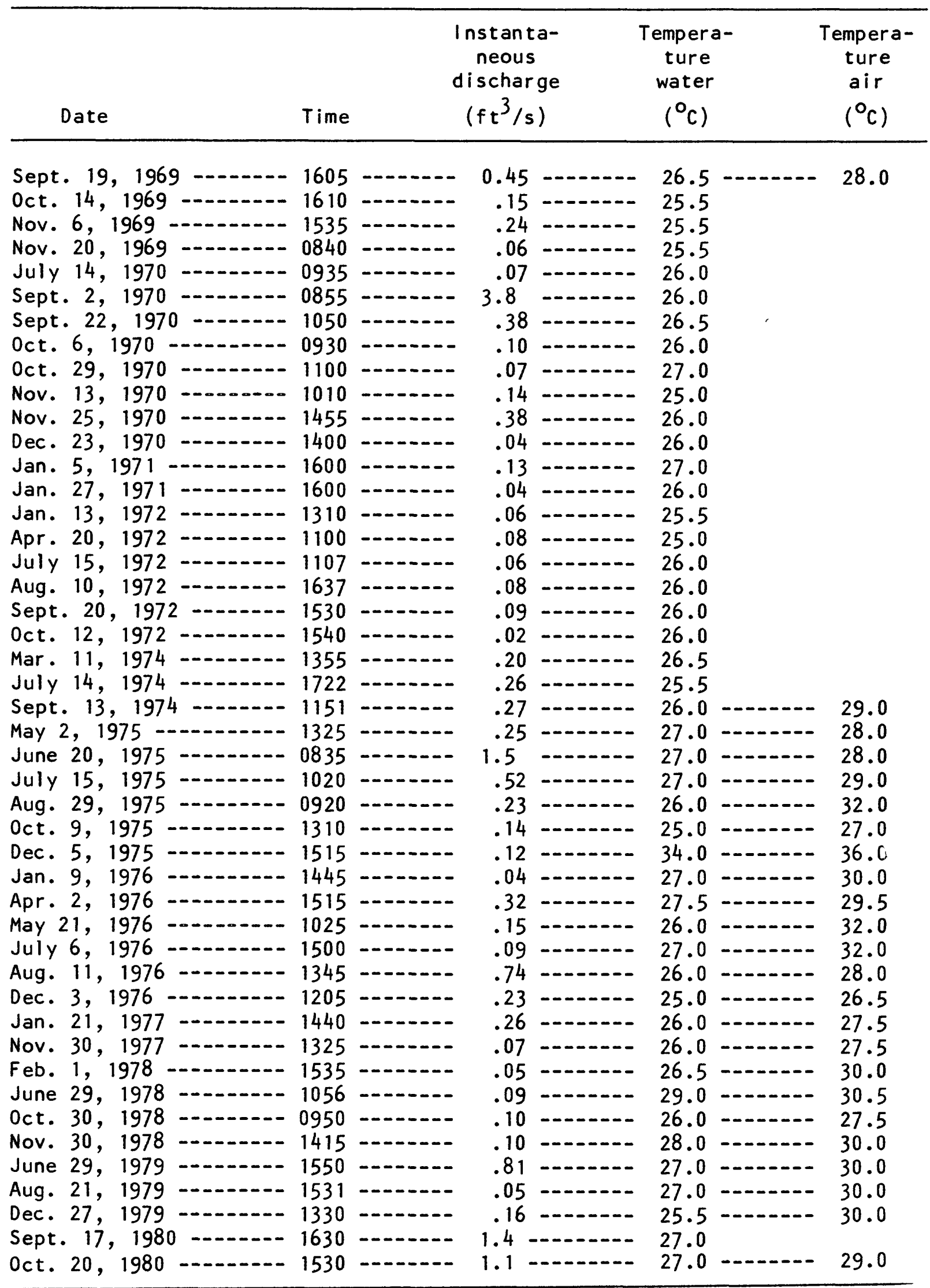


Table 67. Water and air temperatures and instantaneous discharge at Ripu Stream, Yap

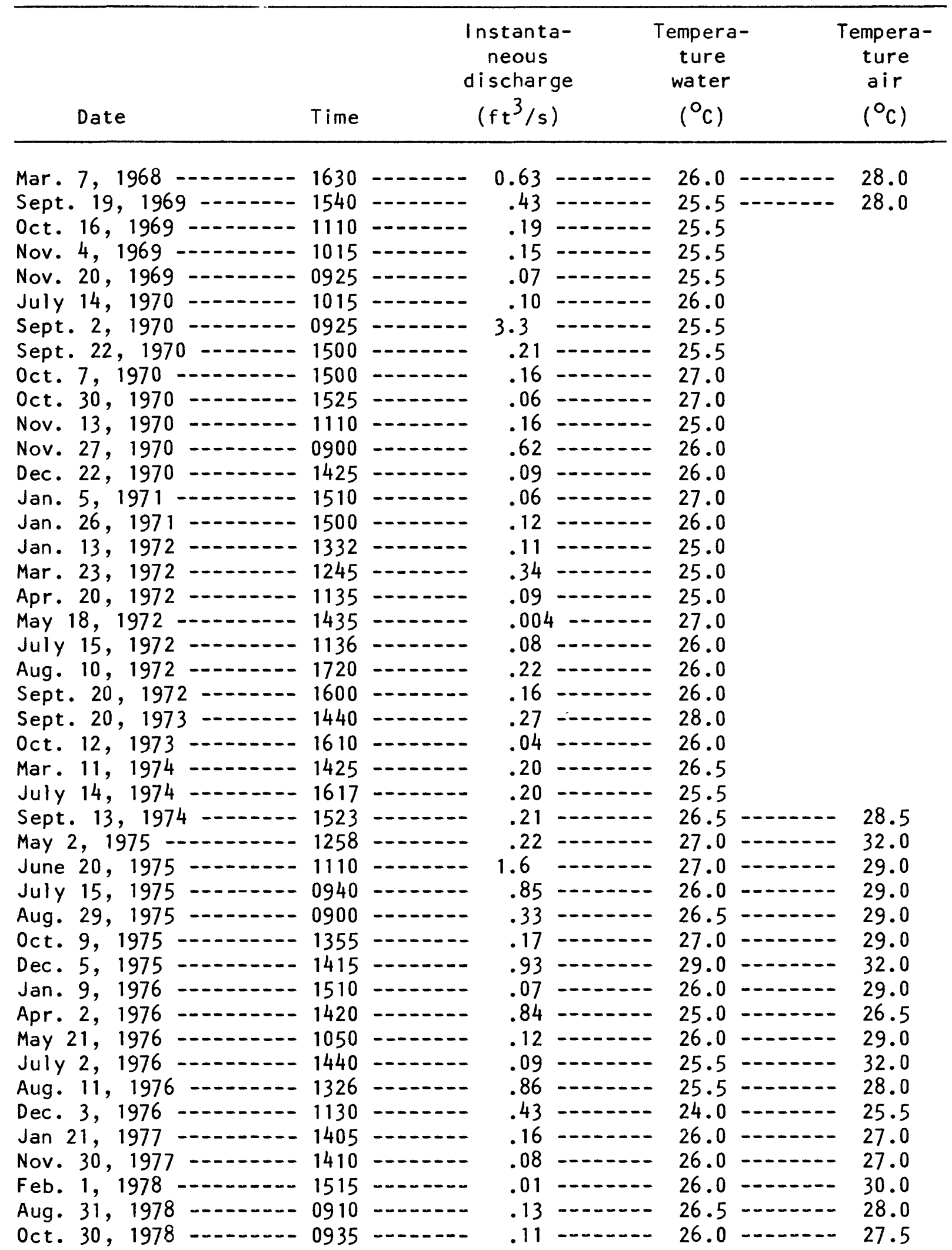


Table 67. Water and air temperatures and instantaneous discharge at Ripu Stream, Yap--Continued

\begin{tabular}{|c|c|c|c|c|c|c|}
\hline Date & Time & & $\begin{array}{c}\text { Instanta- } \\
\text { neous } \\
\text { discharge } \\
\left(\mathrm{ft}^{3} / \mathrm{s}\right)\end{array}$ & $\begin{array}{c}\text { Tempera- } \\
\text { ture } \\
\text { water } \\
\left({ }^{\circ} \mathrm{C}\right)\end{array}$ & & $\begin{array}{c}\text { Tempera- } \\
\text { ture } \\
\text { air } \\
\left({ }^{\circ} \mathrm{C}\right)\end{array}$ \\
\hline $\begin{array}{l}\text { Nov. } 30,1978 \\
\text { June } 29,1979 \\
\text { Aug. } 21,1979 \\
\text { Dec. } 27,1979 \\
\text { Sept. } 17,1980 \\
\text { Oct. } 21,1980\end{array}$ & $\begin{array}{l}1345 \\
1525 \\
1515 \\
1355 \\
1530 \\
1045\end{array}$ & 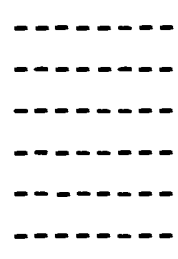 & $\begin{array}{l}-\quad 0.11-- \\
-\quad 1.2=- \\
-\quad .14-- \\
-\quad .09-- \\
-\quad 1.5=- \\
-\quad .62=-\end{array}$ & $\begin{array}{l}27.5-. \\
-\quad 27.0-- \\
-\quad 27.0=- \\
-\quad 26.0-- \\
-\quad 26.0 \\
-26.0\end{array}$ & 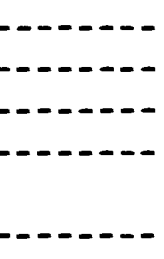 & $\begin{array}{r}30.5 \\
-\quad 32.0 \\
-\quad 28.0 \\
-\quad 31.5 \\
-\quad 27.5\end{array}$ \\
\hline
\end{tabular}

Table 68. Water and air temperatures and instantaneous discharge at Dinaey (Dinay) Stream, Yap

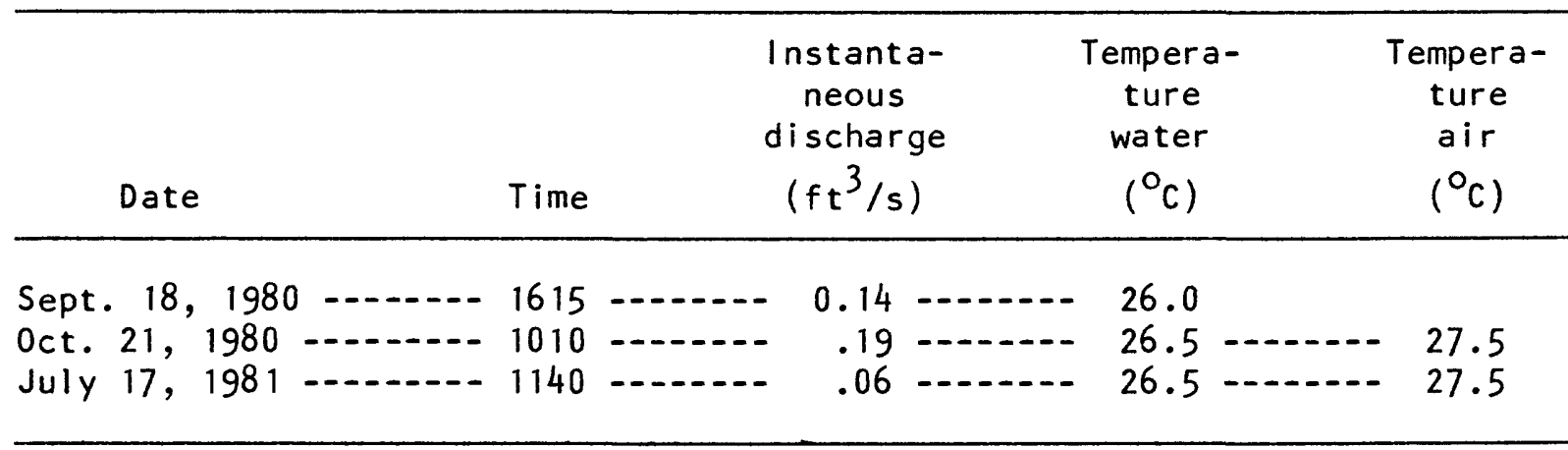


Table 69. Water temperature and instantaneous discharge at Tholomar (Thalomar) Stream, Yap

\begin{tabular}{|c|c|c|c|c|c|}
\hline Date & Time & & $\begin{array}{c}\text { Instanta } \\
\text { neous } \\
\text { discharg } \\
\left(f t^{3} / s\right)\end{array}$ & & $\begin{array}{c}\text { Tempera- } \\
\text { ture } \\
\text { water } \\
\left({ }^{\circ} \mathrm{C}\right)\end{array}$ \\
\hline $\begin{array}{l}\text { Sept. } 30,1969 \\
\text { Oct. } 14,1969 \\
\text { Nov. } 4,1969 \\
\text { July } 14,1970 \\
\text { Sept. } 2,1970 \\
\text { Sept. } 23,1970 \\
\text { Oct. } 6,1970 \\
\text { Oct. } 29,1970 \\
\text { Nov. } 13,1970 \\
\text { Nov. } 27,1970 \\
\text { Dec. } 22,1970 \\
\text { Jan. } 6,1971 \\
\text { Jan. } 27,1971 \\
\text { Jan. } 13,1972 \\
\text { Apr. } 20,1972 \\
\text { May } 18,1972 \\
\text { July } 15,1972 \\
\text { Aug. } 11,1972 \\
\text { Sept. } 20,1972 \\
\text { Oct. } 13,1972 \\
\text { Jan. } 11,1973 \\
\text { Mar. } 11,1973 \\
\text { Sept. } 18,1980 \\
\text { Oct. } 21,1980 \\
\text { July } 23,1981\end{array}$ & $\begin{array}{l}1010 \\
1245 \\
0920 \\
1045 \\
0950 \\
1330 \\
1330 \\
1600 \\
1410 \\
0920 \\
1450 \\
1020 \\
1420 \\
1400 \\
1215 \\
1507 \\
1213 \\
1006 \\
1645 \\
1126 \\
1017 \\
1512 \\
1450 \\
0915 \\
0940\end{array}$ & 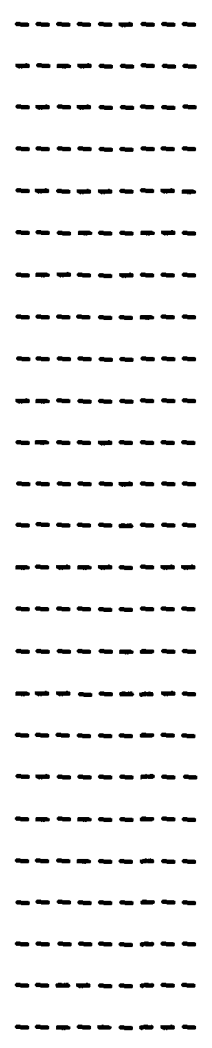 & $\begin{array}{c}0.64 \\
.32 \\
.25 \\
.08 \\
3.8 \\
.26 \\
.28 \\
.11 \\
.22 \\
.70 \\
.16 \\
.18 \\
.10 \\
.11 \\
.09 \\
.01 \\
.06 \\
.21 \\
.14 \\
.03 \\
.02 \\
.23 \\
.43 \\
.32 \\
.07\end{array}$ & (1, & $\begin{array}{l}26.0 \\
26.0 \\
26.0 \\
26.0 \\
26.0 \\
26.0 \\
26.0 \\
26.0 \\
26.0 \\
26.0 \\
26.0 \\
26.0 \\
25.0 \\
25.0 \\
25.0 \\
26.0 \\
26.0 \\
25.0 \\
26.0 \\
25.0 \\
28.0 \\
26.5 \\
26.5 \\
26.5 \\
26.5\end{array}$ \\
\hline
\end{tabular}


Table 70. Water and air temperatures and instantaneous discharge at Daloelaeb (Dalolab) Stream, Yap

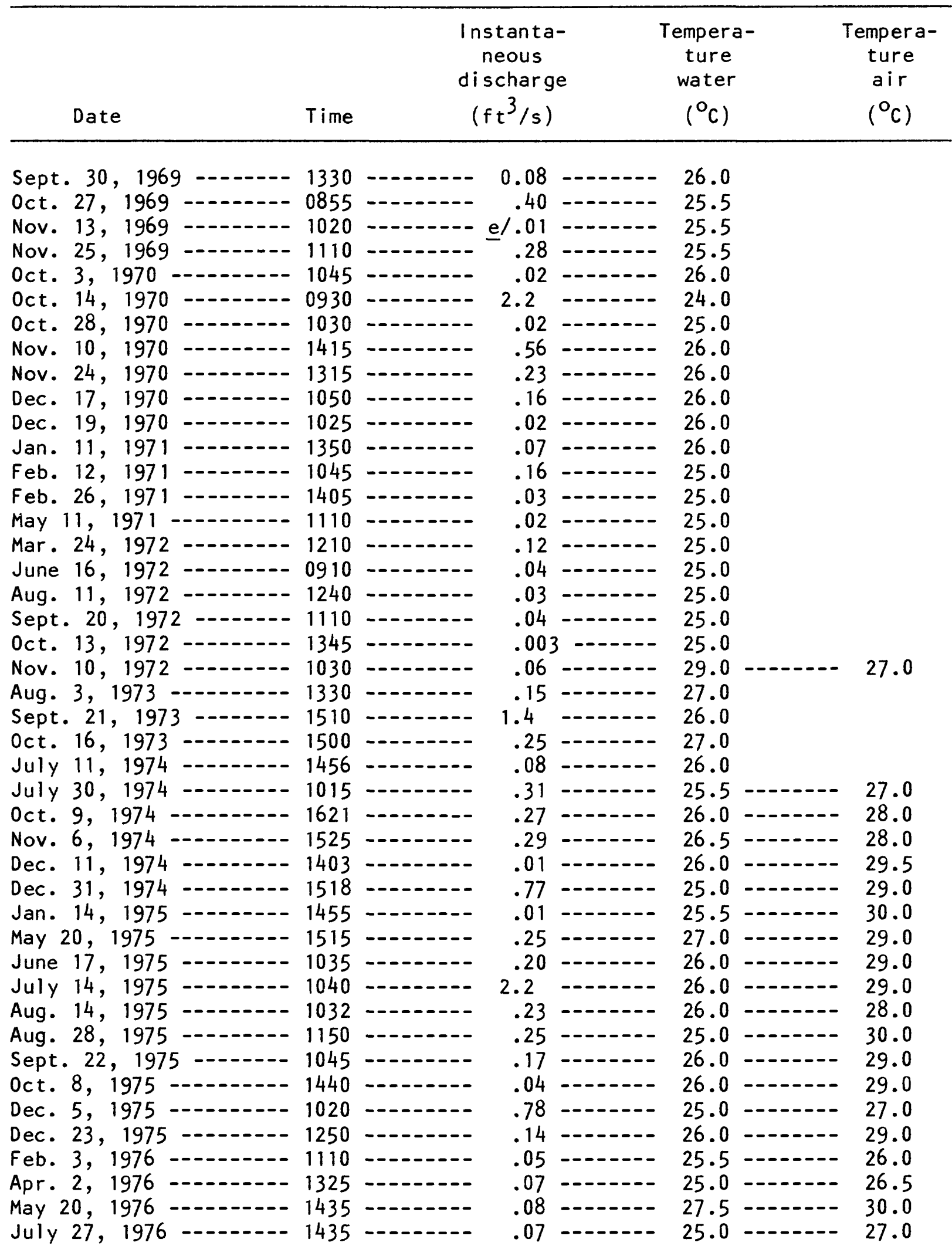


Table 70. Water and air temperatures and instantaneous discharge at Daloelaeb (Dalolab) Stream, Yap--Continued

\begin{tabular}{|c|c|c|c|c|c|c|c|}
\hline Date & Time & & $\begin{array}{c}\text { Instanta- } \\
\text { neous } \\
\text { discharge } \\
\left(f t^{3} / s\right)\end{array}$ & & $\begin{array}{c}\text { Tempera- } \\
\text { ture } \\
\text { water } \\
\left({ }^{\circ} \mathrm{C}\right)\end{array}$ & & $\begin{array}{c}\text { Tempera- } \\
\text { ture } \\
\text { air } \\
\left({ }^{\circ} \mathrm{C}\right)\end{array}$ \\
\hline $\begin{array}{l}\text { Aug. } 11,1976 \\
\text { Aug. } 26,1976 \\
\text { Sept. } 16,1976 \\
\text { Dec. } 2,1976 \\
\text { Dec. } 30,1976 \\
\text { Jan. } 21,1977 \\
\text { Aug. } 12,1977 \\
\text { Sept. } 29,1977 \\
\text { Nov. } 29,1977 \\
\text { Dec. } 16,1977 \\
\text { Sept. } 19,1978 \\
\text { Sept. } 29,1978 \\
\text { Oct. } 30,1978 \\
\text { Nov. } 15,1978 \\
\text { Dec. } 13,1978 \\
\text { Mar. } 15,1979 \\
\text { June } 13,1979 \\
\text { June } 29,1979 \\
\text { July } 11,1979 \\
\text { July } 26,1979 \\
\text { Aug. } 8,1979 \\
\text { Aug. } 21,1979 \\
\text { Oct. } 10,1979 \\
\text { Dec. } 26,1979 \\
\text { June } 3,1980 \\
\text { June } 30,1980 \\
\text { July } 23,1980 \\
\text { July } 31,1980 \\
\text { Sept. } 2,1980 \\
\text { Sept. } 17,1980 \\
\text { Oct. } 8,1980\end{array}$ & $\begin{array}{l}1250 \\
1510 \\
1420 \\
1330 \\
1030 \\
1025 \\
1450 \\
1015 \\
1440 \\
1205 \\
1030 \\
1010 \\
0905 \\
0900 \\
1125 \\
1450 \\
0940 \\
1005 \\
1055 \\
1115 \\
1110 \\
1135 \\
0925 \\
1055 \\
1500 \\
1020 \\
1040 \\
1020 \\
1025 \\
1400 \\
1155\end{array}$ & 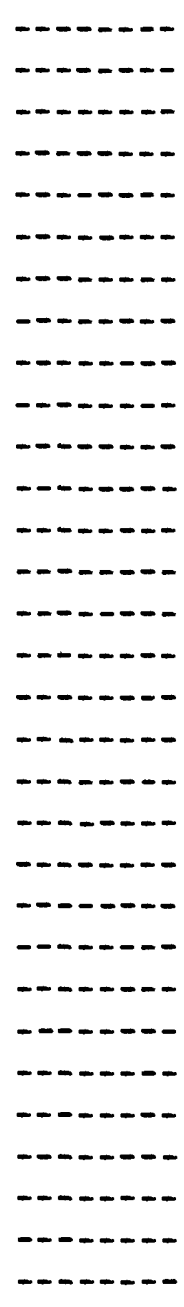 & 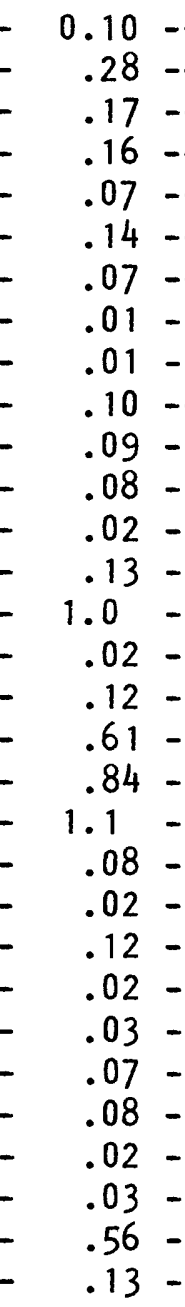 & ' & $\begin{array}{l}26.0- \\
26.0- \\
26.0- \\
26.0- \\
25.5- \\
25.0- \\
26.0- \\
26.0- \\
26.0- \\
26.5- \\
25.5- \\
27.0- \\
26.0- \\
25.5- \\
25.5- \\
26.0- \\
25.5- \\
26.0- \\
26.0- \\
25.5- \\
25.5- \\
26.0- \\
26.5- \\
25.0- \\
27.0- \\
26.0- \\
26.0- \\
26.0- \\
25.5- \\
26.0 \\
25.0-\end{array}$ & (1) & $\begin{array}{l}27.5 \\
27.5 \\
28.5 \\
27.0 \\
27.5 \\
26.5 \\
28.5 \\
29.0 \\
29.0 \\
28.0 \\
27.0 \\
29.0 \\
27.5 \\
28.0 \\
26.5 \\
29.5 \\
27.0 \\
29.0 \\
28.0 \\
26.5 \\
26.0 \\
32.0 \\
27.5 \\
26.5 \\
30.5 \\
29.0 \\
29.0 \\
29.0 \\
26.0 \\
\\
27.0\end{array}$ \\
\hline
\end{tabular}

e/ Estimated. 
Table 71. Water and air temperatures and instantaneous discharge at Peemgoy (Pemgoy) Stream, Yap

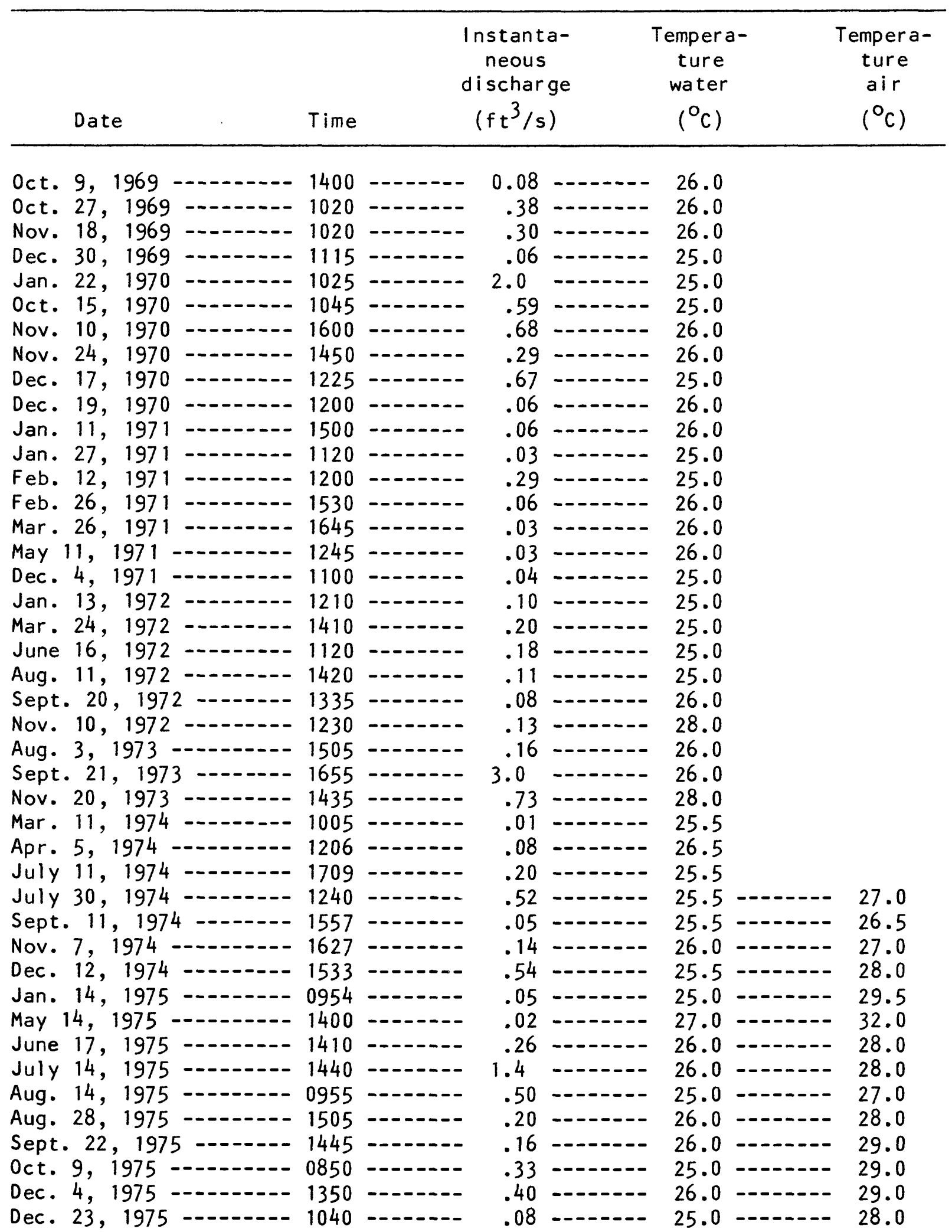


Table 71. Water and air temperatures and instantaneous discharge at Peemgoy (Pemgoy) Stream, Yap--Cont inued

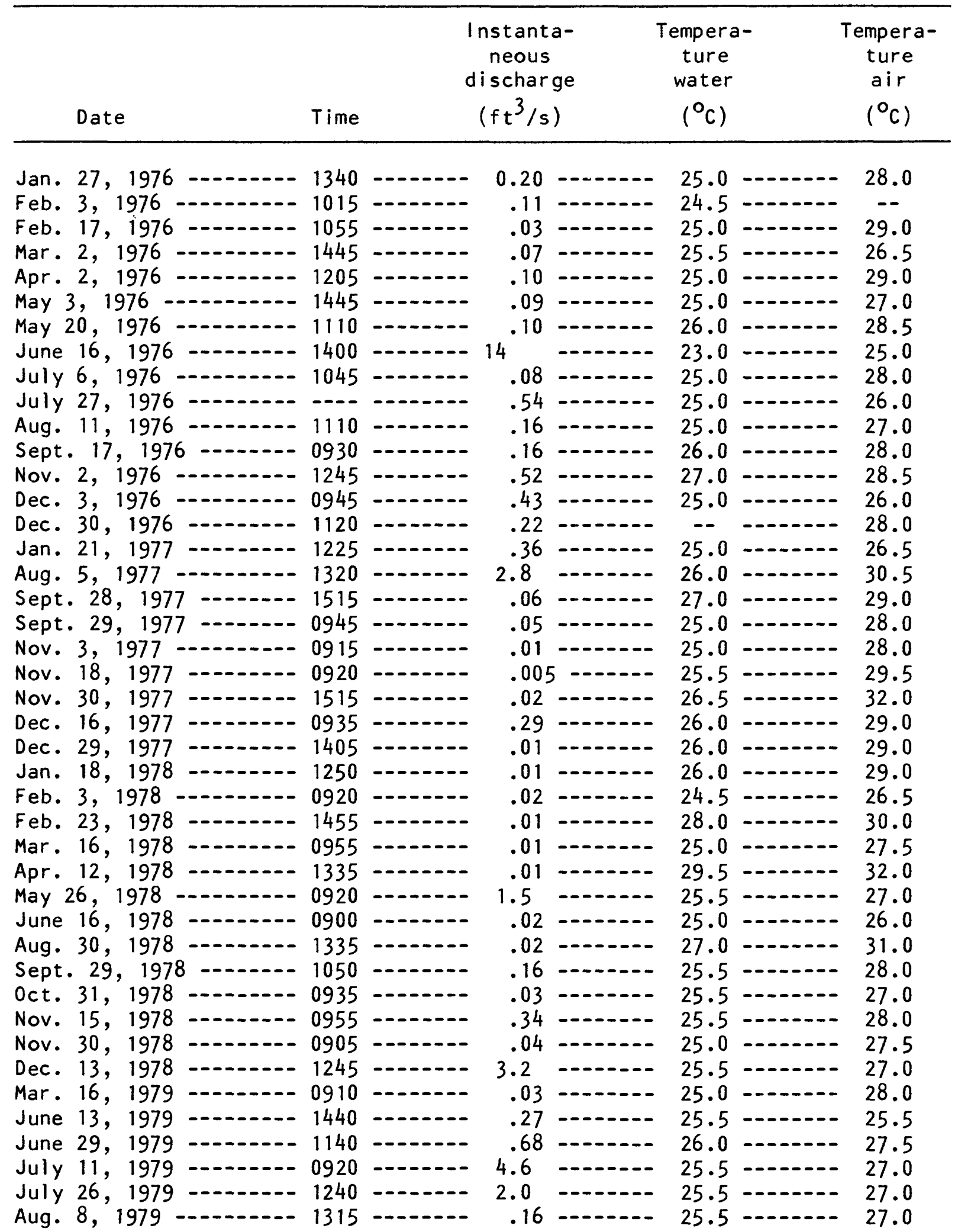


Table 71. Water and air temperatures and instantaneous discharge at Peemgoy (Pemgoy) Stream, Yap--Cont inued

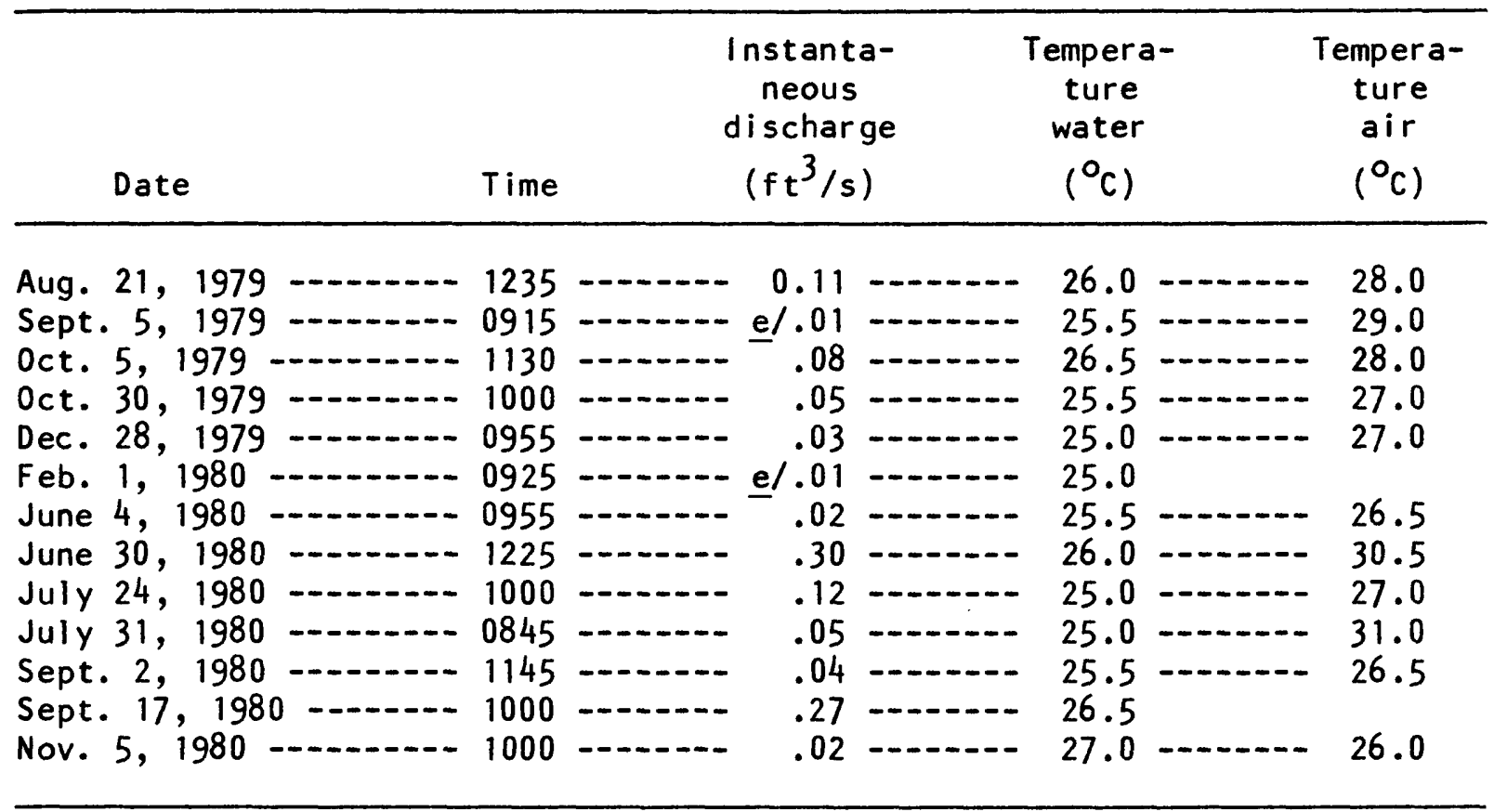

ef Estimated. 
Table 72. Water and air temperatures and instantaneous discharge at Taalgum (Talagu) Stream, Yap

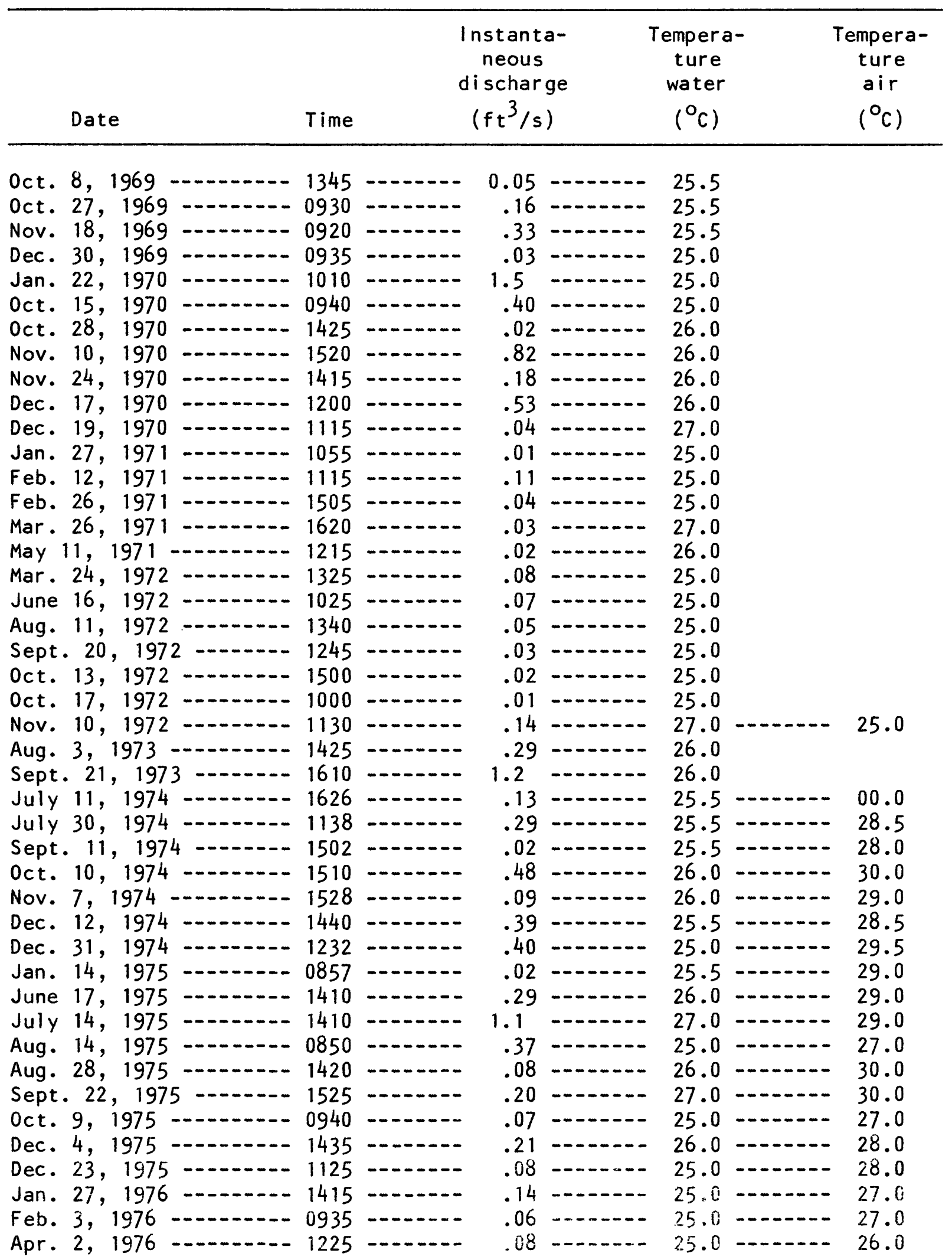


Table 72. Water and air temperatures and instantaneous discharge at Taalgum (Talagu) Stream, Yap--Continued

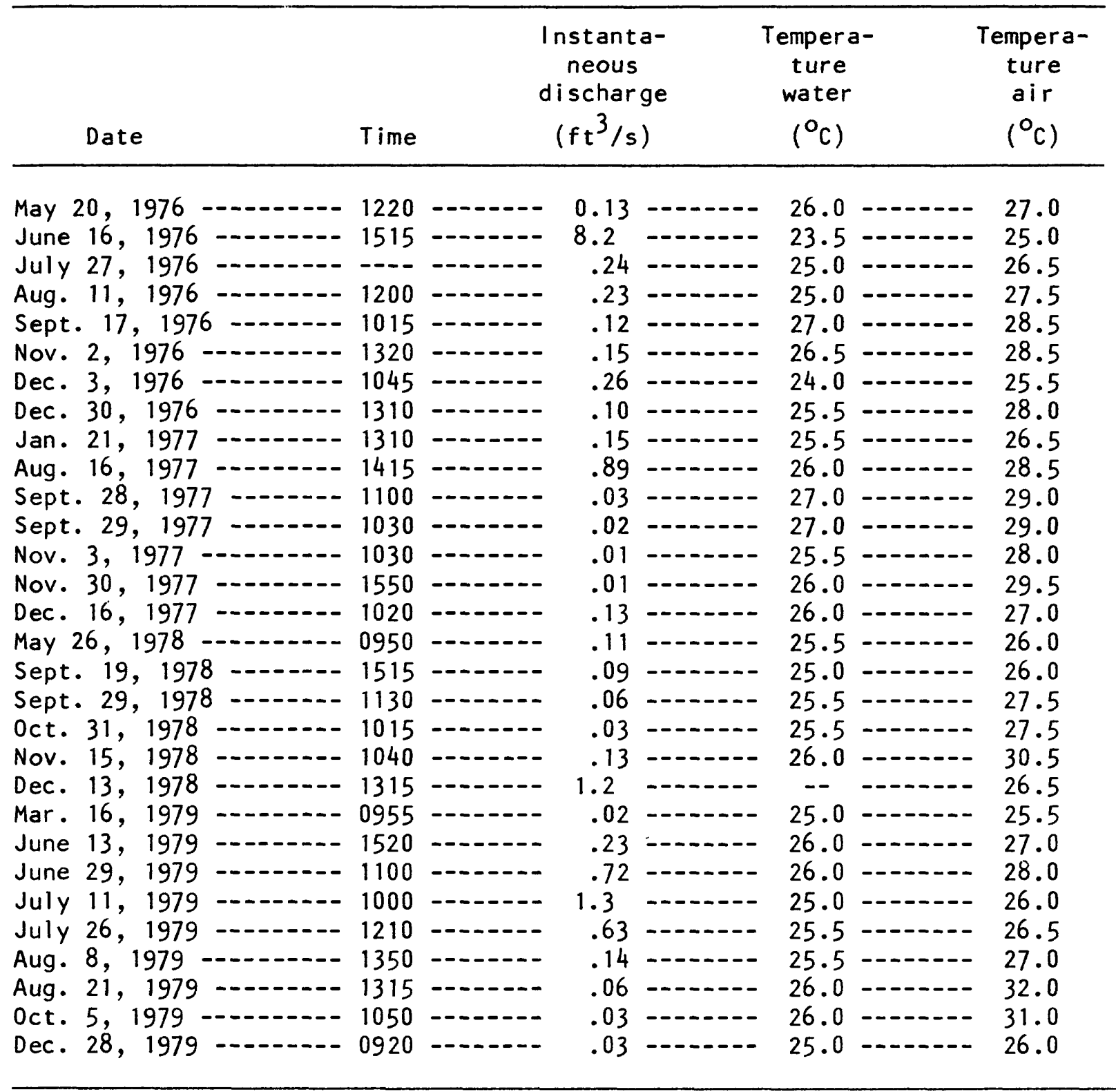


Table 73. Water temperature and instantaneous discharge at Mabuuq (Mabu) Stream, Yap

\begin{tabular}{|c|c|c|c|c|c|}
\hline Date & Time & & $\begin{array}{l}\text { tanta- } \\
\text { eous } \\
\text { charge } \\
\left.t^{3} / \mathrm{s}\right)\end{array}$ & & $\begin{array}{c}\text { Tempera- } \\
\text { ture } \\
\text { water } \\
\left({ }^{\circ} \mathrm{C}\right)\end{array}$ \\
\hline $\begin{array}{l}\text { Sept. } 18,1969 \\
\text { Oct. } 8,1969 \\
\text { Nov. 4, } 1969 \\
\text { Nov. } 20,1969 \\
\text { Jan. } 21,1970 \\
\text { July } 14,1970 \\
\text { Sept. } 24,1970 \\
\text { Oct. } 7,1970 \\
\text { Oct. } 29,1970 \\
\text { Nov. 13, } 1970 \\
\text { Nov. } 27,1970 \\
\text { Dec. 22, } 1970 \\
\text { Jan. } 6,1971 \\
\text { Jan. } 14,1972 \\
\text { Apr. } 21,1972 \\
\text { June } 16,1972 \\
\text { Aug. } 11,1972 \\
\text { Sept. } 20,1972\end{array}$ & $\begin{array}{l}1110 \\
1610 \\
0835 \\
1005 \\
0946 \\
1115 \\
1025 \\
1100 \\
1110 \\
1320 \\
1030 \\
1530 \\
1100 \\
1550 \\
1535 \\
1600 \\
1510 \\
1730\end{array}$ & & $\begin{array}{l}0.14- \\
.14- \\
.37- \\
.11- \\
.42- \\
.03- \\
.03= \\
.12- \\
.36- \\
.16- \\
.60- \\
.18- \\
.07- \\
.08- \\
.01- \\
.51- \\
.16- \\
.13-\end{array}$ & 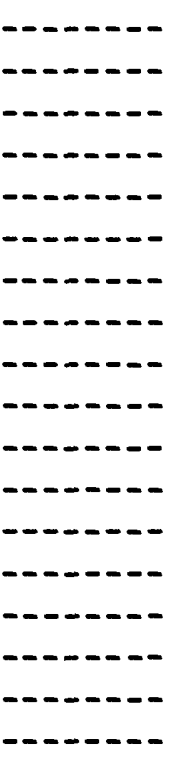 & $\begin{array}{l}25.5 \\
-\quad 26.0 \\
25.5 \\
-25.5 \\
-25.0 \\
-\quad 26.0 \\
25.5 \\
-\quad 25.0 \\
25.0 \\
26.0 \\
27.0 \\
26.0 \\
26.0 \\
-\quad 25.0 \\
25.0 \\
25.0 \\
-\quad 25.0 \\
26.0\end{array}$ \\
\hline
\end{tabular}


Table 74. Water and air temperatures and instantaneous discharge at Burong Stream, Yap

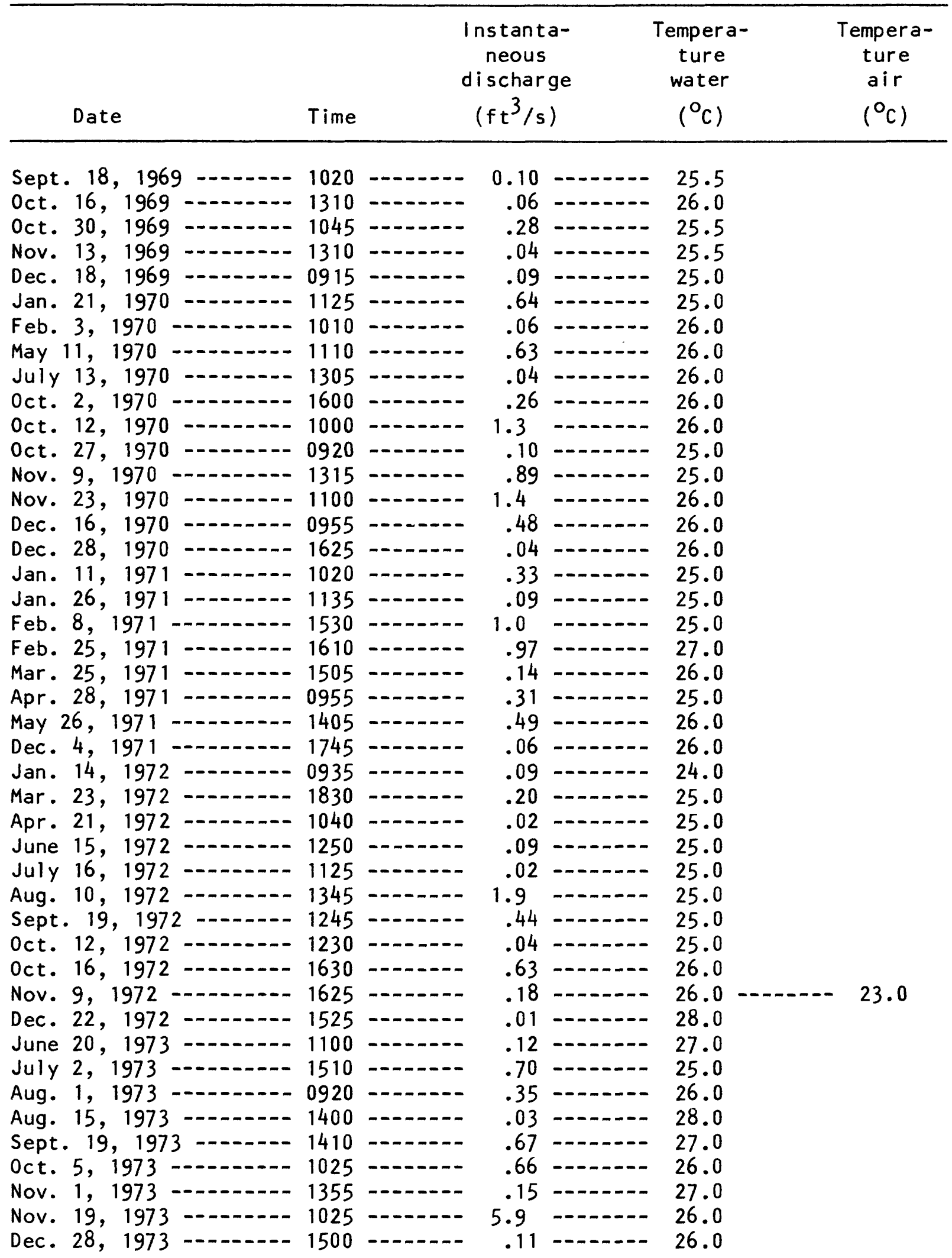


Table 74. Water and air temperatures and instantaneous discharge at Burong Stream, Yap--Cont inued

\begin{tabular}{|c|c|c|c|c|c|c|c|}
\hline Date & Time & & $\begin{array}{r}\text { Instant } \\
\text { neous } \\
\text { dischar } \\
\left(\mathrm{ft}^{3} / \mathrm{s}\right.\end{array}$ & & $\begin{array}{c}\text { Tempera } \\
\text { ture } \\
\text { water } \\
\left({ }^{\circ} \mathrm{C}\right)\end{array}$ & & $\begin{array}{c}\text { Tempera- } \\
\text { ture } \\
\text { air } \\
\left({ }^{\circ} \mathrm{C}\right)\end{array}$ \\
\hline July 11,1974 & 1028 & - & 0.50 & & 25.5 & & \\
\hline Sept. $21,1974 \ldots$ & 1510 & 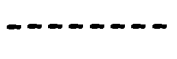 & .24 & $\cdots-n$ & 27.0 & $\cdots-n$ & 32.5 \\
\hline 0ct. 7,1974 & 1410 & $-\cdots-n$ & 1.3 & $\cdots-\cdots$ & 26.0 & $-\cdots-n$ & 5 \\
\hline Nov. $5,1974 \ldots$ & 1508 & $m-m-n$ & 8.5 & $-\cdots-n$ & 25.5 & $m-\cdots-\infty$ & 29.0 \\
\hline Dec. $3,1974 \ldots$ & 1015 & $-m-n-n$ & .03 & $-\ldots-n$ & 25.0 & 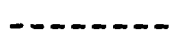 & 28.5 \\
\hline Dec. $30,1974 \ldots$ & 1514 & $\ldots-n-$. & .43 & -- & 26.5 & $\ldots-n$ & 29.5 \\
\hline Jan. $14,1975 \ldots$ & 1555 & -- & .05 & $\ldots \ldots-n$ & 26.0 & $\cdots-\cdots$ & 30.0 \\
\hline May $20,1975 \ldots$ & 1345 & $-\cdots---n$ & .32 & $-\cdots---$ & 27.0 & $\cdots-n$ & 30.0 \\
\hline June $16,1975 \ldots$ & 1435 & $\cdots-\cdots$ & .22 & $-\cdots-n$ & 27.0 & $-\cdots---\infty$ & 28.0 \\
\hline July $8,1975 \ldots$ & 1320 & $-\ldots-n$ & .91 & $-\ldots-n$ & 26.0 & 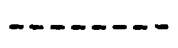 & 29.0 \\
\hline Aug. $25,1975 \ldots$ & 1010 & $--\cdots-n$ & .40 & $\ldots-\ldots$ & 26.0 & $-\ldots-n$ & 28.0 \\
\hline Sept. 18, $1975 \ldots$ & 1402 & 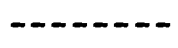 & 2.4 & 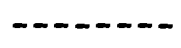 & 26.0 & $---n-\infty$ & 32.0 \\
\hline oct. $7,1975 \ldots$ & 1230 & $\cdots \cdots$ & 1.2 & $m-n-m$ & 26.0 & $\cdots-n-m$ & 30.0 \\
\hline Nov. 5, $1975 \ldots$ & 1110 & 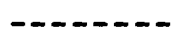 & .07 & $-\cdots-n-\infty$ & 26.0 & $m-n-m$ & 28.0 \\
\hline Dec. 3, $1975 \ldots$ & 1337 & $-\cdots-n$ & .36 & 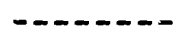 & 29.0 & $\cdots-n$ & 32.0 \\
\hline Dec. $22,1975 \ldots$ & 1050 & $-\cdots-n$ & .87 & $\cdots-\cdots$ & 24.0 & -...... & 27.0 \\
\hline Jan. 9, 1976 & 0940 & $\cdots-\cdots$ & .06 & $-\cdots-n--$ & 25.0 & 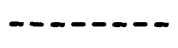 & 28.0 \\
\hline Jan. $27,1976 \ldots$ & 1115 & $----\cdots$ & .33 & $\ldots \ldots-n$ & 26.0 & $-\cdots--\infty$ & 29.0 \\
\hline Feb. 3, 1976 & 1502 & $\cdots-\cdots$ & .14 & $-\cdots-n$ & 26.0 & -n. & 27.5 \\
\hline Apr. 1, $1976 \ldots$ & 1330 & 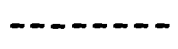 & .98 & $\ldots \ldots-n$ & 26.5 & 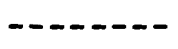 & 32.0 \\
\hline May 3, $1976 \ldots$ & 1230 & $---n-\infty$ & .06 & $-\ldots-n$ & 26.0 & $\ldots-n$ & 29.0 \\
\hline May 19, $1976 \ldots$ & 1410 & $-\cdots---\infty$ & .43 & 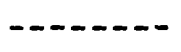 & 26.5 & $-\cdots---$ & 30.0 \\
\hline June $15,1976 \ldots$ & 1330 & $\cdots \cdots$ & .29 & 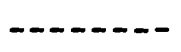 & 26.0 & $-\ldots-n$ & 29.0 \\
\hline July 6, 1976 & 1250 & $\ldots-n-\infty$ & .06 & $-\cdots-n$ & 28.0 & $\ldots-n$ & 34.5 \\
\hline July $26,1976 \ldots$ & 1135 & $-\ldots-n$ & .62 & $\ldots-n$ & 25.5 & $\ldots-\ldots$ & 28.0 \\
\hline Aug. $10,1976 \ldots$ & 1450 & $-\cdots-\infty--$ & .27 & $-\cdots$ & 25.5 & -n. & 27.0 \\
\hline Aug. $26,1976 \ldots$ & 1300 & $-\cdots-\infty-n$ & .84 & $-\ldots-n$ & 26.0 & - & 28.5 \\
\hline Sept. $16,1976 \ldots$ & 1120 & $-\cdots-n-n$ & .57 & $-\cdots$ & 26.0 & $-2-n-n$ & 28.0 \\
\hline Nov. 2, 1976 & 1120 & $-\ldots-\ldots$ & .11 & $-\ldots-\ldots$ & 25.0 & $\ldots-\ldots$ & 26.0 \\
\hline Dec. $2,1976 \ldots$ & 1100 & $-\cdots-n$ & .29 & $\ldots \ldots-n$ & 23.0 & $m-n-m$ & 25.0 \\
\hline Dec. $29,1976 \ldots$ & 1345 & $\ldots \ldots$ & 1.2 & $m-n-m$ & 26.0 & $-\cdots-n-\infty$ & 29.0 \\
\hline Jan. $20,1977 \ldots$ & 1240 & 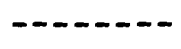 & .16 & 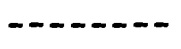 & 26.0 & 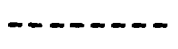 & 28.5 \\
\hline June $30,1977 \ldots$ & 1430 & 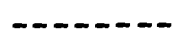 & .06 & 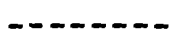 & 28.0 & -...... & 31.5 \\
\hline Aug. 9, $1977 \ldots$ & 1530 & $-\ldots-n$ & .09 & 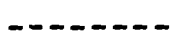 & 28.0 & 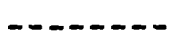 & 30.0 \\
\hline Sept. $26,1977 \ldots$ & 1600 & $\ldots-\ldots$ & .16 & $---n---$ & 26.0 & $-\infty-\cdots$ & 29.0 \\
\hline Sept. $29,1977 \ldots$ & 1630 & $\ldots-\ldots$ & .32 & $-\ldots-n$ & 27.0 & $--\cdots-n$ & 29.0 \\
\hline Nov. $16,1977 \ldots$ & 1515 & 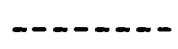 & .01 & $--\cdots-n$ & 27.5 & $-\cdots---$ & 31.5 \\
\hline lov. $30,1977 \ldots$ & 1030 & $\ldots-\ldots$ & .10 & $\ldots-\ldots-n$ & 26.5 & $-\cdots-n$ & 30.0 \\
\hline Dec. 14,1977 & 1330 & $-\ldots-n$ & 2.1 & --- & 27.0 & -...... & 30.0 \\
\hline Dec. $30,1977 \ldots$ & 1345 & $\ldots \ldots$ & .01 & $\cdots-$ & 28.0 & $---n-n$ & 30.5 \\
\hline Jan. $12,1978 \ldots$ & 1020 & $-\cdots-n$ & .01 & $\ldots-\cdots$ & 26.0 & $-\cdots-n$ & 28.5 \\
\hline Feb. $1,1978 \ldots$ & 1130 & - & .03 & $\cdots-\cdots$ & 27.0 & 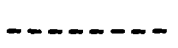 & 29.0 \\
\hline June 28,1978 & 1055 & - & .14 & $-\cdots$ & 25.5 & $-\ldots$ & 28.5 \\
\hline Aug. $30,1978 \ldots$ & 1110 & $--\infty-\infty$ & .08 & $-\ldots-n$ & 26.5 & $\ldots \ldots$ & 31.0 \\
\hline
\end{tabular}


Table 74. Water and air temperatures and instantaneous discharge at Burong Stream, Yap--Cont inued

\begin{tabular}{|c|c|c|c|c|c|c|c|}
\hline Date & Time & & $\begin{array}{l}\text { Instanta } \\
\text { neous } \\
\text { discharg } \\
\left(f t^{3} / s\right)\end{array}$ & & $\begin{array}{c}\text { Tempera- } \\
\text { ture } \\
\text { water } \\
\left({ }^{\circ} \mathrm{C}\right)\end{array}$ & & $\begin{array}{c}\text { Tempera- } \\
\text { ture } \\
\text { air } \\
\left({ }^{\circ} \mathrm{C}\right)\end{array}$ \\
\hline 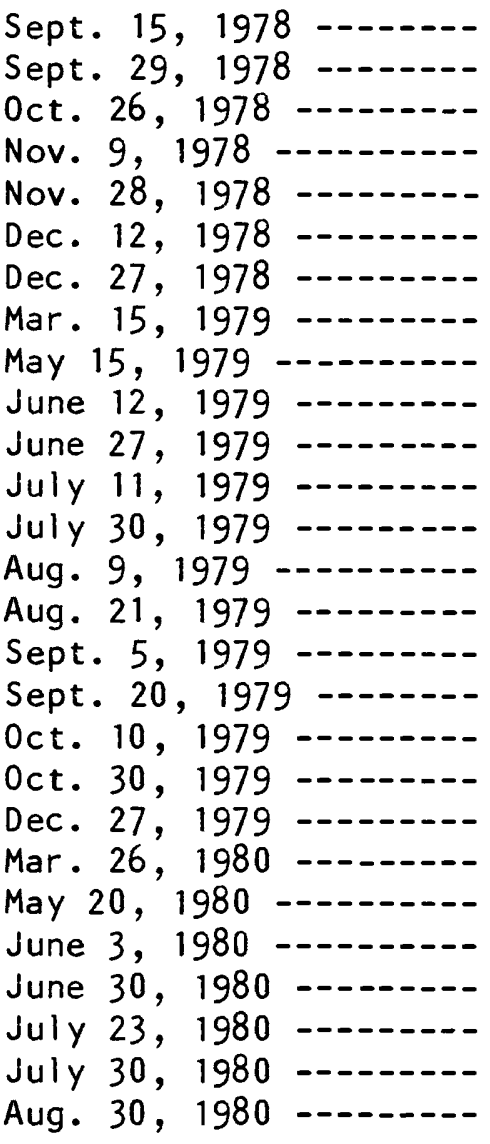 & $\begin{array}{l}1445 \\
1440 \\
1050 \\
0910 \\
1320 \\
1030 \\
1340 \\
1055 \\
1015 \\
1340 \\
1045 \\
1350 \\
1040 \\
1200 \\
1235 \\
1200 \\
1235 \\
1520 \\
1520 \\
1135 \\
1010 \\
1445 \\
1050 \\
0905 \\
0925 \\
1345 \\
1310\end{array}$ & 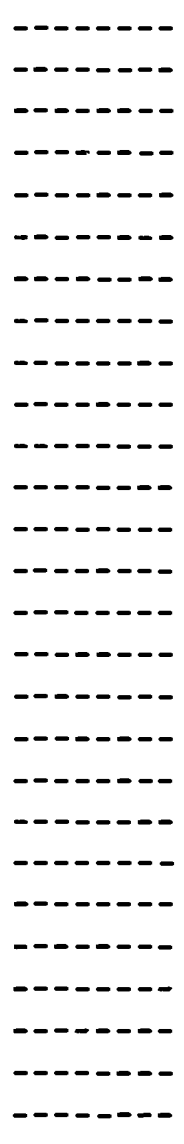 & $\begin{array}{c}1.5 \\
.17 \\
.11 \\
2.9 \\
.06 \\
1.0 \\
.04 \\
.21 \\
.61 \\
2.5 \\
1.2 \\
2.4 \\
.12 \\
3.6 \\
.21 \\
.02 \\
.07 \\
.18 \\
.10 \\
.07 \\
.04 \\
.03 \\
.06 \\
.44 \\
.42 \\
.19 \\
2.1\end{array}$ & (1) & $\begin{array}{c}26.5- \\
28.5- \\
26.0- \\
26.0- \\
26.5- \\
26.0- \\
26.5- \\
25.0- \\
-- \\
25.5- \\
26.0- \\
26.5- \\
25.5- \\
25.5- \\
26.5- \\
27.0- \\
27.0- \\
-- \\
25.0- \\
26.0- \\
25.5- \\
27.5- \\
-- \\
25.5- \\
26.0- \\
27.0- \\
25.0-\end{array}$ & $\begin{array}{l}\text { (1) } \\
\end{array}$ & $\begin{array}{l}29.5 \\
30.5 \\
28.5 \\
28.5 \\
30.0 \\
27.5 \\
30.5 \\
24.0 \\
28.5 \\
28.0 \\
28.0 \\
32.0 \\
28.0 \\
27.0 \\
32.0 \\
30.0 \\
30.0 \\
26.0 \\
27.5 \\
32.0 \\
28.5 \\
35.0 \\
28.5 \\
27.5 \\
28.5 \\
32.0 \\
27.0\end{array}$ \\
\hline
\end{tabular}


Table 75. Water and air temperatures and instantaneous discharge at Monguch Stream, Gagil-Tamil

\begin{tabular}{|c|c|c|c|c|c|}
\hline Date & Time & & $\begin{array}{c}\text { Instanta- } \\
\text { neous } \\
\text { discharge } \\
\left(\mathrm{ft}^{3} / \mathrm{s}\right)\end{array}$ & $\begin{array}{c}\text { Tempera- } \\
\text { ture } \\
\text { water } \\
\left({ }^{\circ} \mathrm{C}\right)\end{array}$ & $\begin{array}{c}\text { Tempera- } \\
\text { ture } \\
\text { air } \\
\left({ }^{\circ} \mathrm{C}\right)\end{array}$ \\
\hline $\begin{array}{l}\text { Sept. 16, } 1980 \\
\text { Oct. 20, } 1980 \\
\text { Mar. } 24,1981 \\
\text { Apr. } 7,1981 \\
\text { Apr. } 27,1981 \\
\text { May 14, 1981 } \\
\text { July 22, } 1981\end{array}$ & $\begin{array}{l}1440 \\
1210 \\
1335 \\
1250 \\
1300 \\
1150 \\
1040\end{array}$ & 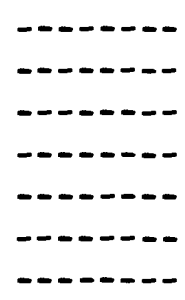 & $\begin{array}{l}-\quad 1.3-- \\
-\quad .44-- \\
-\quad .16-- \\
-\quad .08- \\
-\quad .26= \\
-\quad .12= \\
-\quad 1.6=-\end{array}$ & $\begin{array}{l}-\quad 28.0-- \\
-\quad 26.0= \\
-\quad 27.5-- \\
-\quad 29.0- \\
-\quad 27.5=- \\
-\quad 28.0=- \\
-\quad 27.5=\end{array}$ & $\begin{array}{l}29.0 \\
28.5 \\
28.5 \\
30.5 \\
28.0 \\
28.5 \\
30.5\end{array}$ \\
\hline
\end{tabular}

Table 76. Water and air temperatures and instantaneous discharge at Mukong Stream, Gagil-Tamil

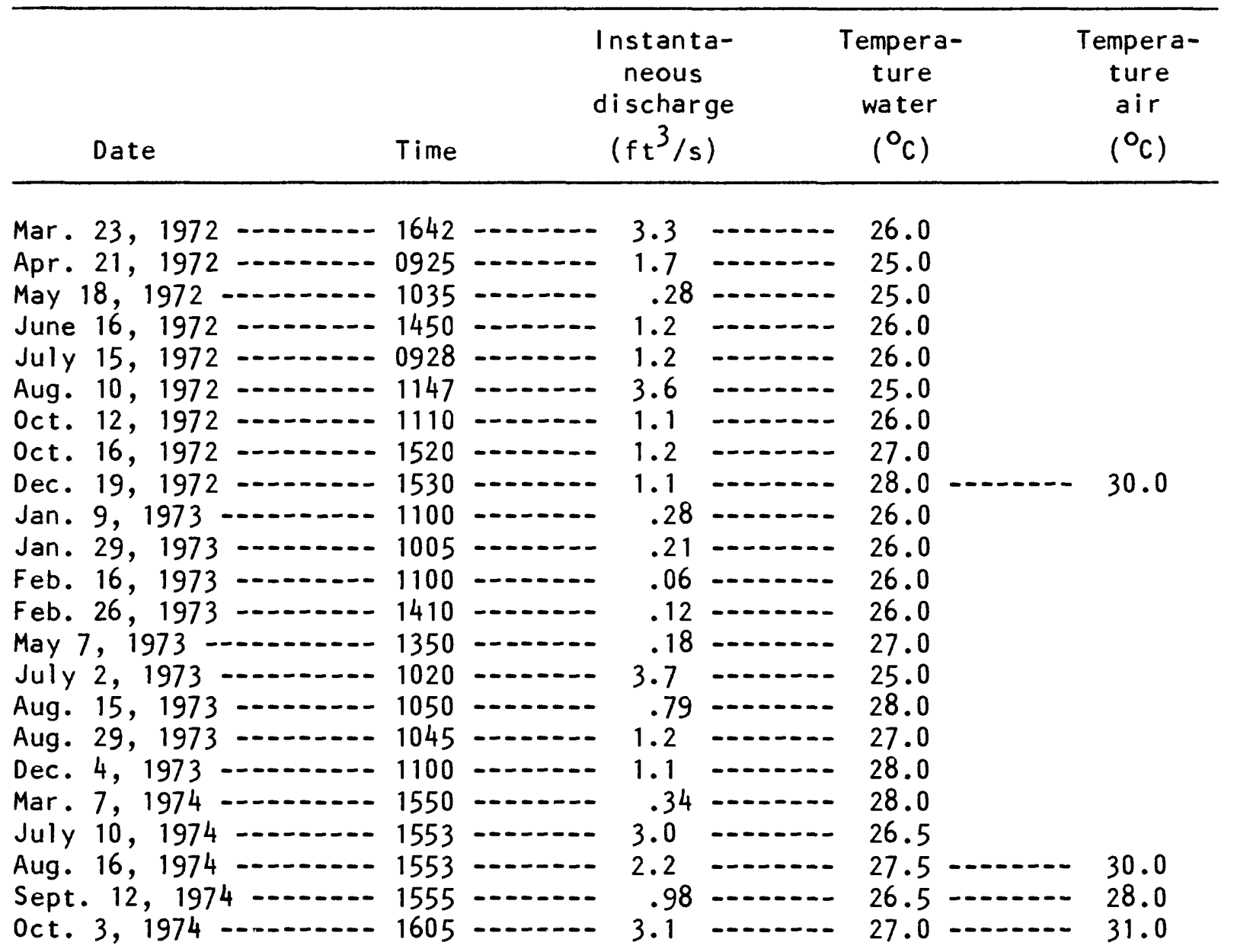


Table 76. Water and air temperatures and instantaneous discharge at Mukong Stream, Gagil-Tami 1--Continued

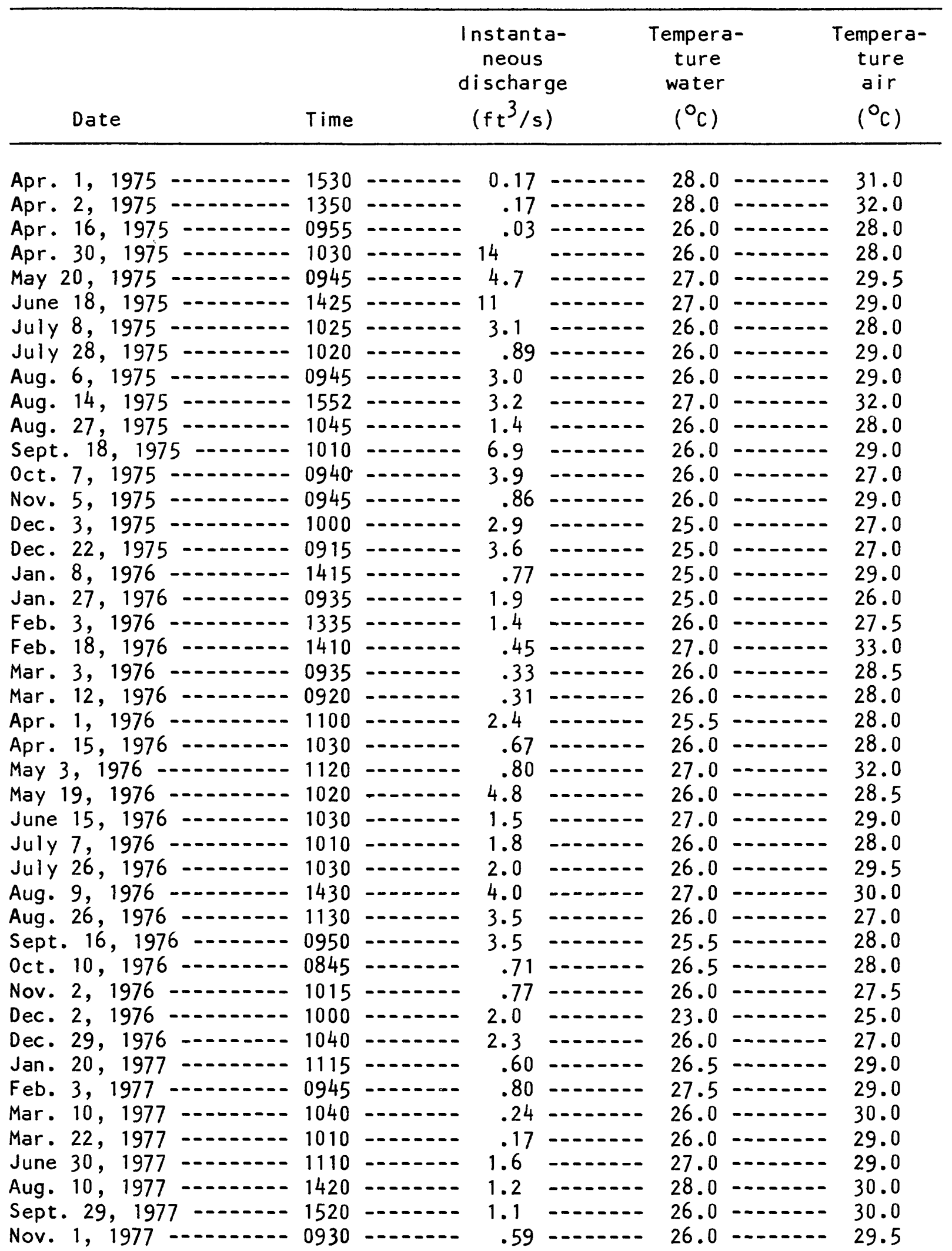


Table 76. Water and air temperatures and instantaneous discharge at Mukong Stream, Gagil-Tamil--Continued

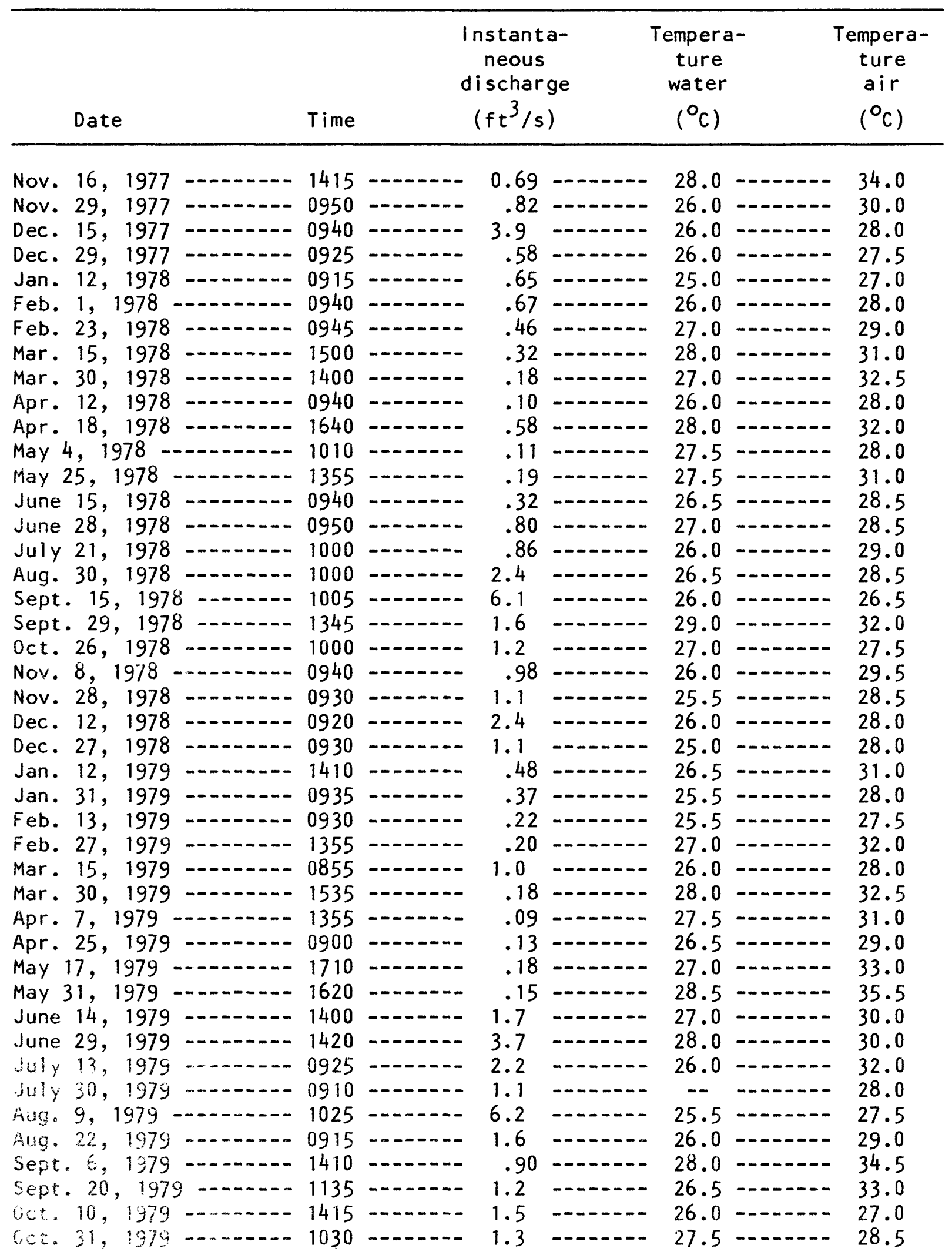


Table 76. Water and air temperatures and instantaneous discharge at Mukong Stream, Gagil-Tami I--Continued

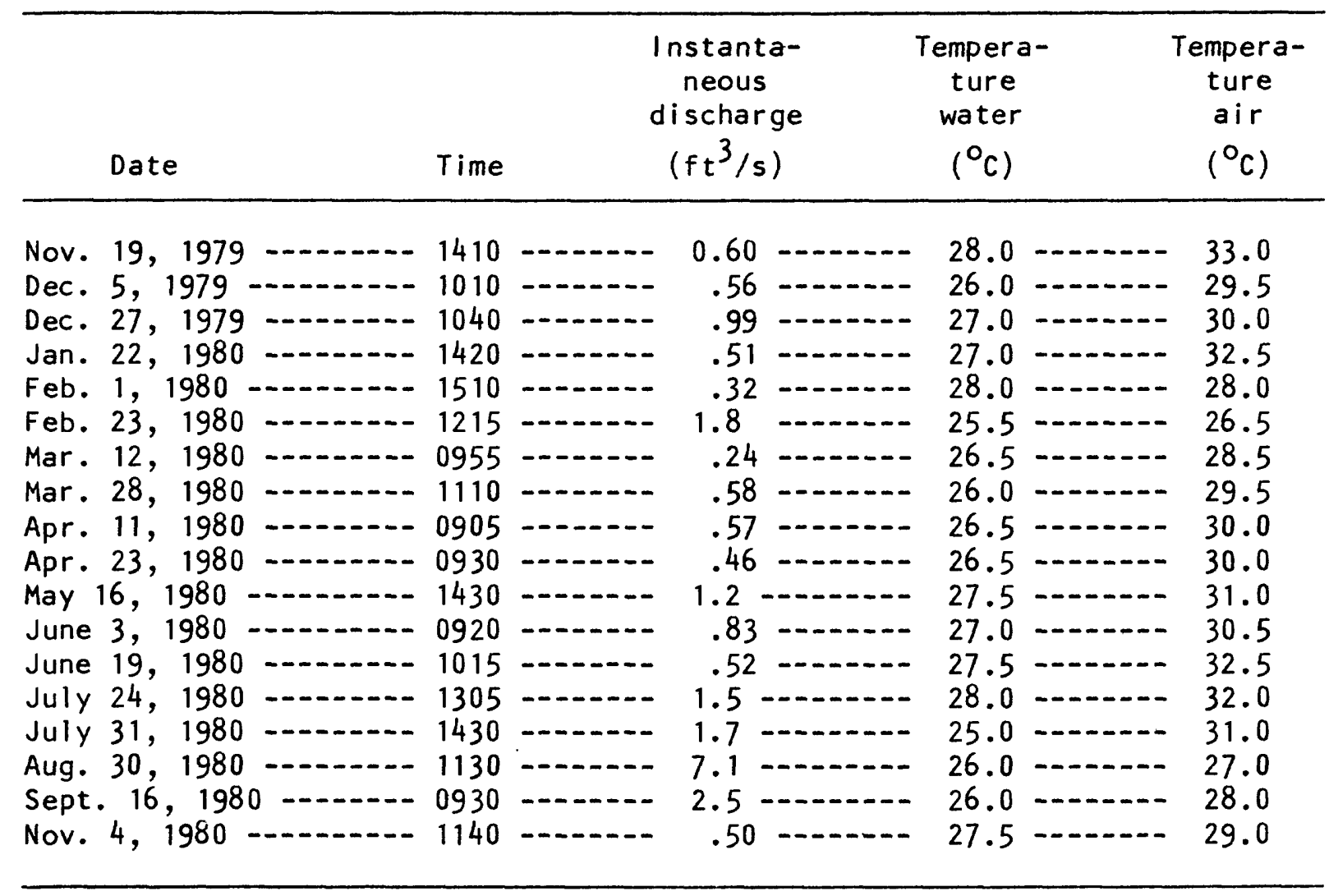


Table 77. Water and air temperatures and instantaneous discharge at Gilaew (Bileiy) Spring, Gagil-Tamil

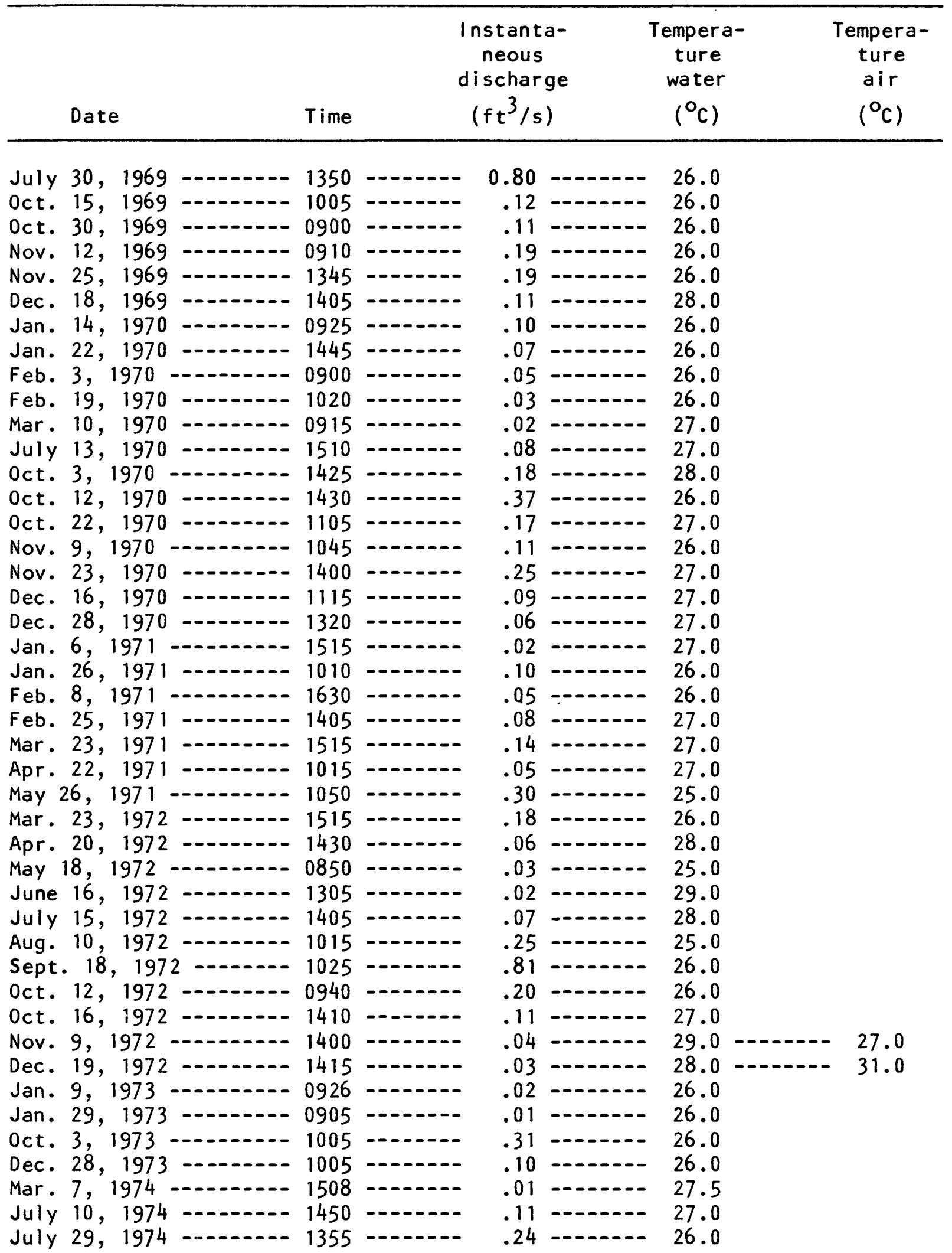


Table 77. Water and air temperatures and instantaneous discharge at Gilaew (Bileiy) Spring, Gagil-Tamil--Continued

\begin{tabular}{|c|c|c|c|c|c|c|c|}
\hline Date & Time & & $\begin{array}{c}\text { Instanta } \\
\text { neous } \\
\text { discharg } \\
\left(\mathrm{ft}^{3} / \mathrm{s}\right)\end{array}$ & & $\begin{array}{c}\text { Tempera- } \\
\text { ture } \\
\text { water } \\
\left({ }^{\circ} \mathrm{C}\right)\end{array}$ & & $\begin{array}{c}\text { Tempera- } \\
\text { ture } \\
\text { air } \\
\left({ }^{\circ} \mathrm{C}\right)\end{array}$ \\
\hline 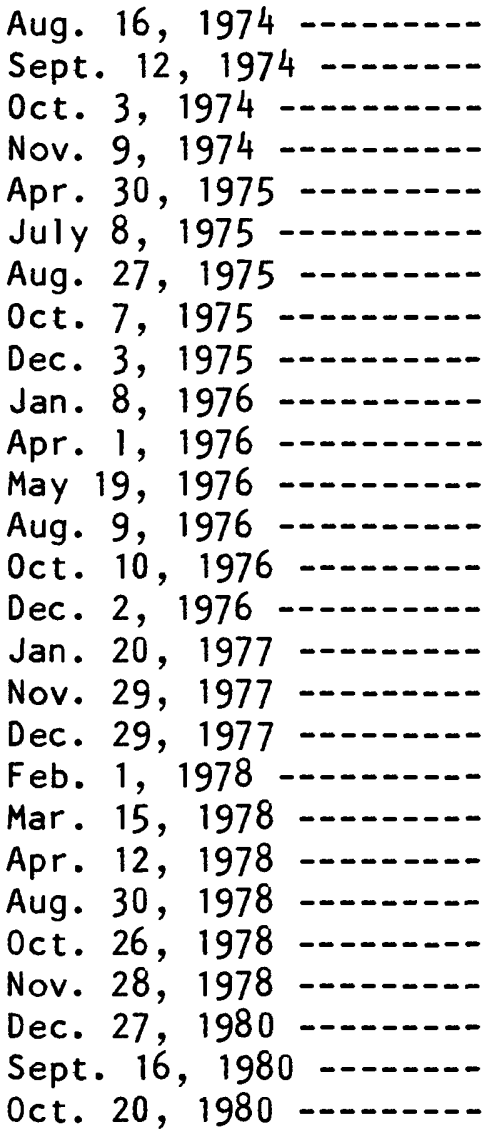 & $\begin{array}{l}1512 \\
1506 \\
1525 \\
1640 \\
1135 \\
1100 \\
1220 \\
1055 \\
1105 \\
1550 \\
1230 \\
1150 \\
1545 \\
0950 \\
0915 \\
0945 \\
1105 \\
1030 \\
1040 \\
1435 \\
0855 \\
0855 \\
0850 \\
1035 \\
0905 \\
1130 \\
1100\end{array}$ & 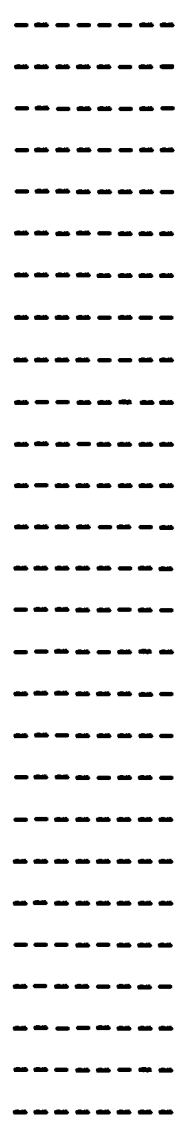 & $\begin{array}{r}0.45 \\
.06 \\
.05 \\
.45 \\
.10 \\
.18 \\
.16 \\
.10 \\
.04 \\
.08 \\
.05 \\
.42 \\
.09 \\
.07 \\
.20 \\
.07 \\
.01 \\
.03 \\
.03 \\
.02 \\
.01 \\
.02 \\
.02 \\
.02 \\
.18 \\
.40 \\
.21\end{array}$ & (1) & $\begin{array}{l}27.0 \\
27.0 \\
25.5 \\
26.0 \\
26.0 \\
26.0 \\
30.0 \\
27.0 \\
26.0 \\
24.0 \\
27.5 \\
27.0 \\
26.0 \\
27.0 \\
24.5 \\
27.0 \\
29.0 \\
26.5 \\
27.0 \\
29.0 \\
26.0 \\
26.0 \\
26.0 \\
26.0 \\
25.0 \\
27.0 \\
27.0\end{array}$ & (1) & $\begin{array}{l}31.5 \\
29.5 \\
32.0 \\
29.0 \\
31.0 \\
29.0 \\
34.0 \\
35.0 \\
29.0 \\
28.0 \\
29.5 \\
30.0 \\
28.0 \\
29.5 \\
26.5 \\
29.0 \\
30.5 \\
30.5 \\
30.0 \\
32.0 \\
28.0 \\
27.5 \\
27.0 \\
30.0 \\
27.0 \\
28.0 \\
29.0\end{array}$ \\
\hline
\end{tabular}


Table 78. Water and air temperatures and instantaneous discharge at Gilaew (Bileiy) Stream, Gagil-Tamil

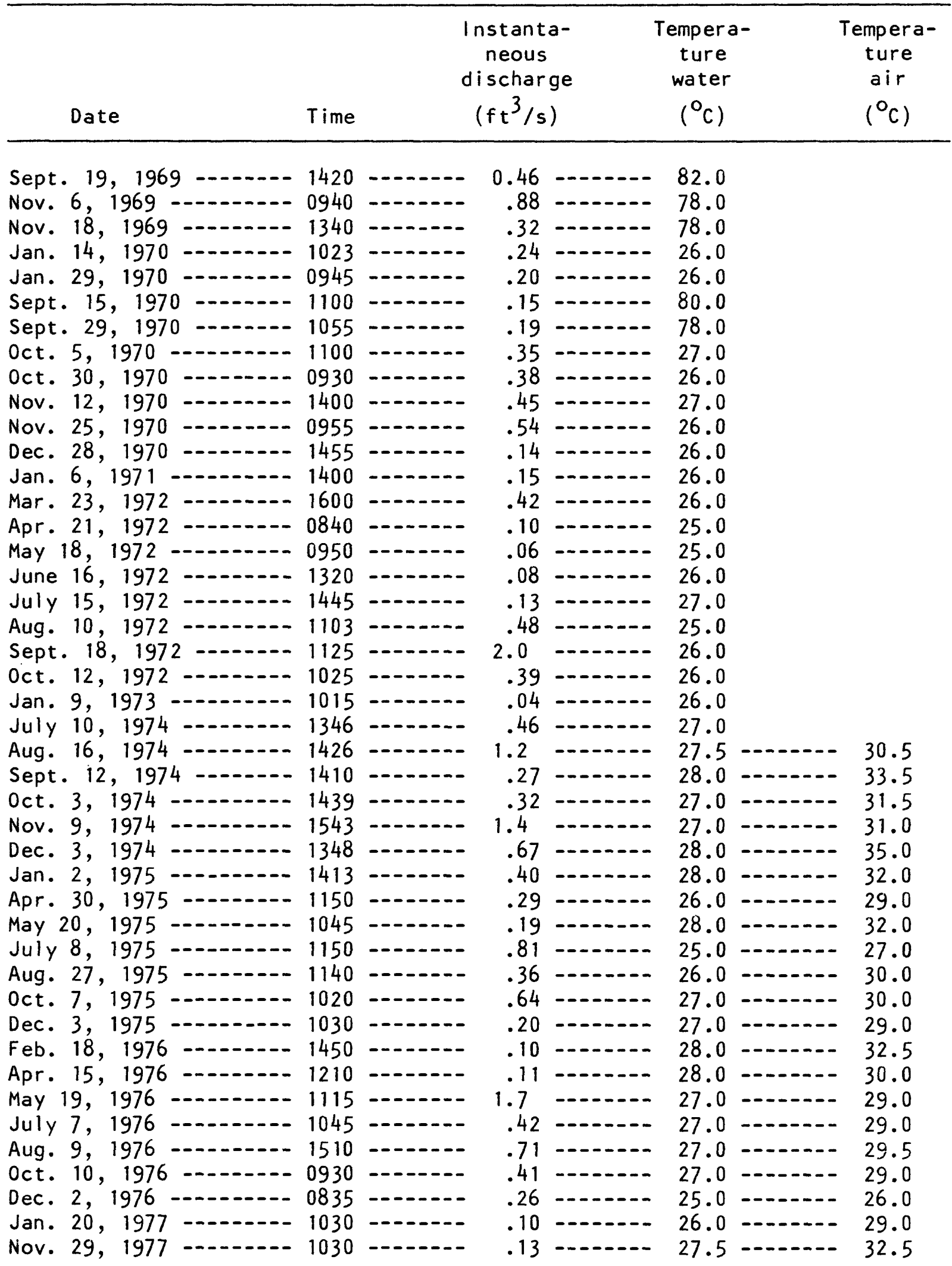


Table 78. Water and air temperatures and instantaneous discharge at Gilaew (Bileiy) Stream, Gagil-Tamil--Continued

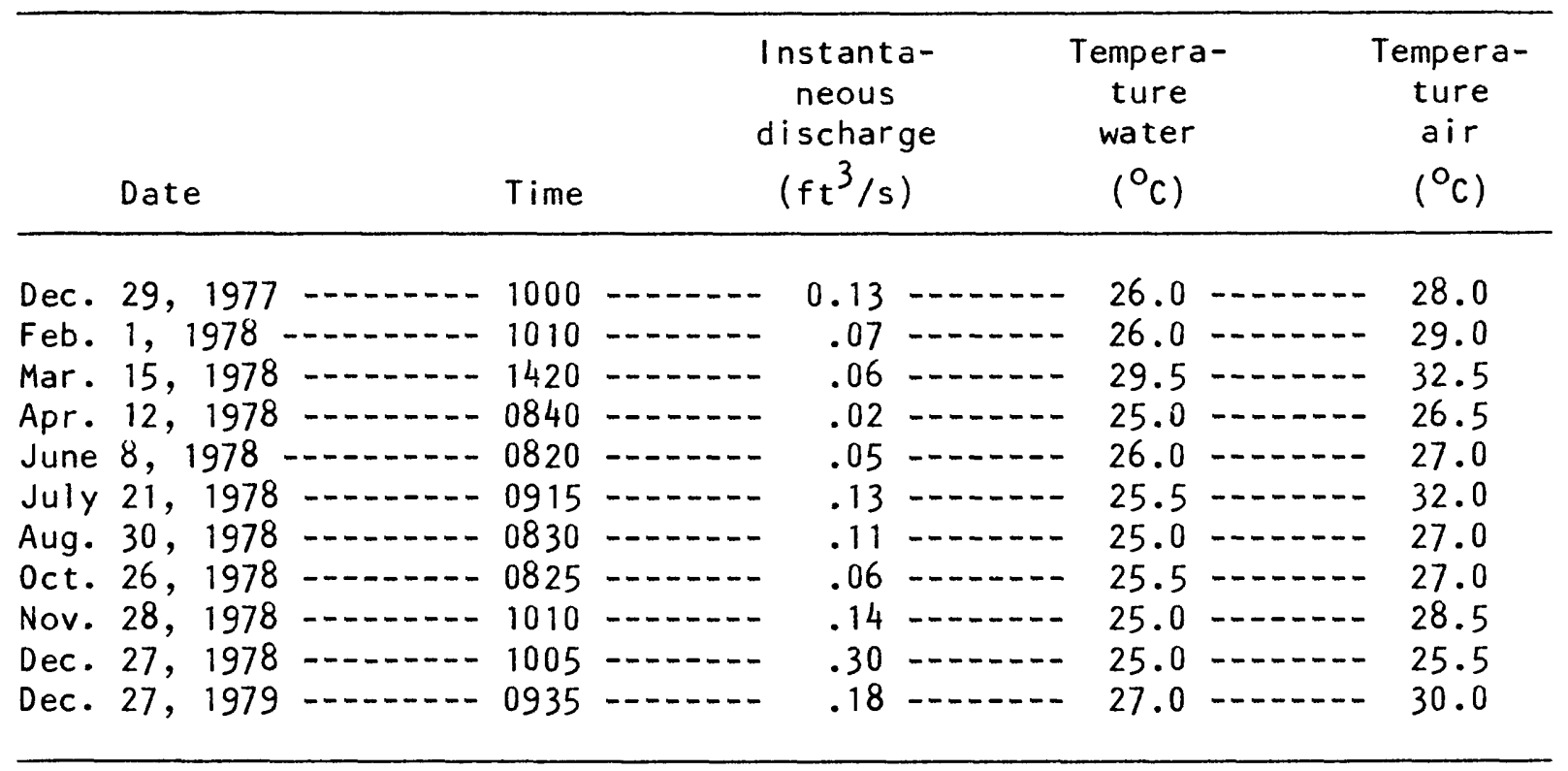

Table 79. Water temperature and instantaneous discharge at Yanbilang Stream, Gagil-Tamil

\begin{tabular}{|c|c|c|c|c|}
\hline Date & Time & & $\begin{array}{c}\text { Instanta- } \\
\text { neous } \\
\text { discharge } \\
\left(f t^{3} / s\right)\end{array}$ & $\begin{array}{c}\text { Tempera- } \\
\text { ture } \\
\text { water } \\
\left({ }^{\circ} \mathrm{C}\right)\end{array}$ \\
\hline $\begin{array}{l}\text { Oct. 15, } 1969 \\
\text { Nov. } 6,1969 \\
\text { Sept. } 29,1970 \\
\text { Oct. } 7,1970 \\
\text { Oct. } 30,1970 \\
\text { Nov. } 12,1970 \\
\text { Nov. } 25,1970 \\
\text { Dec. } 24,1970 \\
\text { Jan. } 6,1971 \\
\text { Jan. } 26,1971\end{array}$ & $\begin{array}{l}0905 \\
1040 \\
1025 \\
1755 \\
1325 \\
1335 \\
0920 \\
1530 \\
1325 \\
0835\end{array}$ & 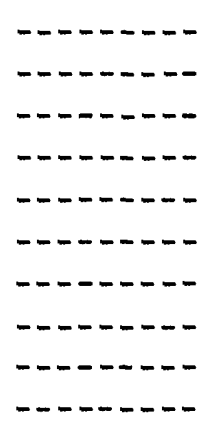 & 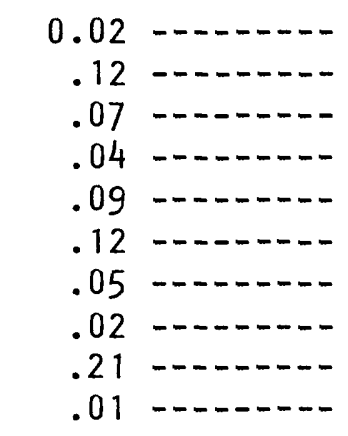 & $\begin{array}{l}25.5 \\
25.5 \\
26.0 \\
28.0 \\
27.0 \\
27.0 \\
26.0 \\
27.0 \\
26.0 \\
26.0\end{array}$ \\
\hline
\end{tabular}


Table 80. Water and air temperatures and instantaneous discharge at Eyeb Stream, Gagil-Tamil

\begin{tabular}{|c|c|c|c|c|c|c|}
\hline Date & Time & & $\begin{array}{c}\text { Instanta- } \\
\text { neous } \\
\text { discharge } \\
\left(\mathrm{ft}^{3} / \mathrm{s}\right)\end{array}$ & $\begin{array}{c}\text { Tempera- } \\
\text { ture } \\
\text { water } \\
\left({ }^{\circ} \mathrm{C}\right)\end{array}$ & & $\begin{array}{c}\text { Tempera- } \\
\text { ture } \\
\text { air } \\
\left({ }^{\circ} \mathrm{C}\right)\end{array}$ \\
\hline 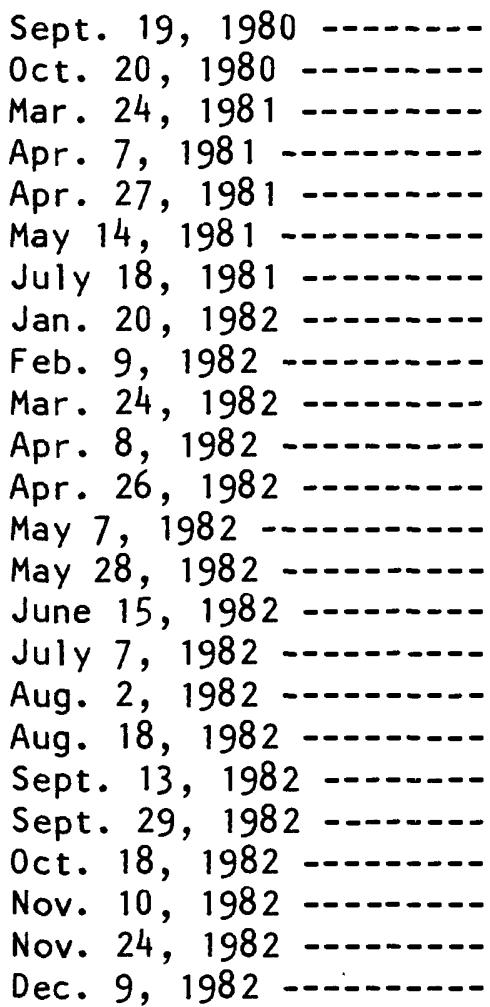 & $\begin{array}{l}1140 \\
1300 \\
1420 \\
1320 \\
1325 \\
1230 \\
1010 \\
1305 \\
1215 \\
0935 \\
1200 \\
1255 \\
1020 \\
1115 \\
1455 \\
1320 \\
1300 \\
1130 \\
1230 \\
1405 \\
1111 \\
1010 \\
1120 \\
1250\end{array}$ & 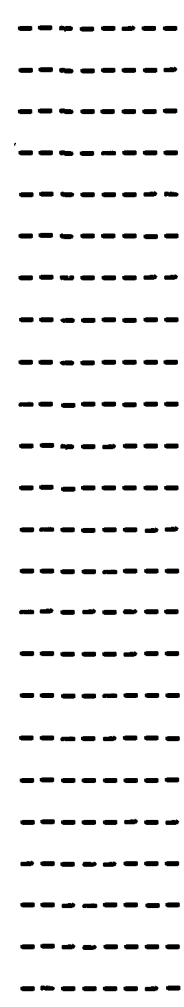 & 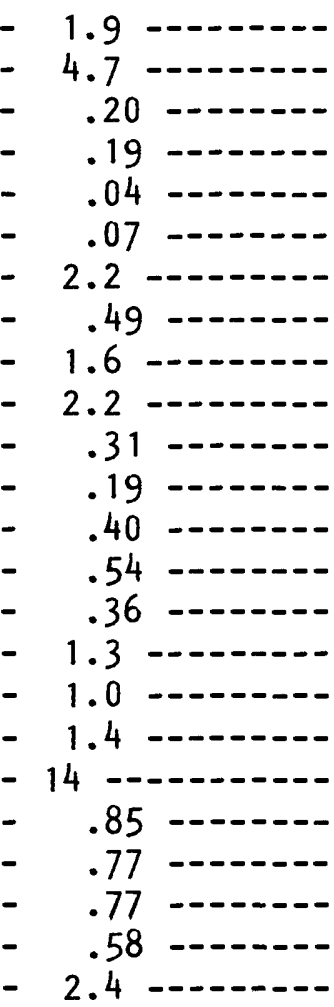 & $\begin{array}{l}26.5 \\
26.0- \\
28.0- \\
28.0- \\
27.5- \\
28.5- \\
26.0 \\
26.5- \\
26.5- \\
25.5- \\
26.0- \\
28.5- \\
27.0 \\
28.0- \\
27.5- \\
27.5- \\
27.0- \\
26.0- \\
26.5- \\
26.5- \\
26.0- \\
26.0- \\
26.0- \\
26.5-\end{array}$ & (1) & $\begin{array}{r}28.0 \\
-\quad 28.0 \\
-\quad 26.5 \\
-\quad 27.5 \\
27.5 \\
-\quad 29.5 \\
-\quad 28.5 \\
-\quad 29.0 \\
-\quad 28.0 \\
27.5 \\
-\quad 27.0 \\
-\quad 28.0 \\
27.0 \\
-\quad 27.5 \\
27.0 \\
27.5\end{array}$ \\
\hline
\end{tabular}

Table 81. Water and air temperatures and instantaneous discharge at Qamin (Amin) Stream, Maap

\begin{tabular}{|c|c|c|c|c|c|}
\hline Date & Time & & $\begin{array}{c}\text { Instanta- } \\
\text { neous } \\
\text { discharge } \\
\left(\mathrm{ft}^{3} / \mathrm{s}\right)\end{array}$ & $\begin{array}{c}\text { Tempera- } \\
\text { ture } \\
\text { water } \\
\left({ }^{\circ} \mathrm{C}\right)\end{array}$ & $\begin{array}{c}\text { Tempera- } \\
\text { ture } \\
\text { air } \\
\left({ }^{\circ} \mathrm{C}\right)\end{array}$ \\
\hline 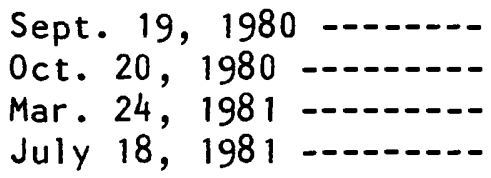 & $\begin{array}{r}1550 \\
-0950 \\
1230 \\
1330\end{array}$ & 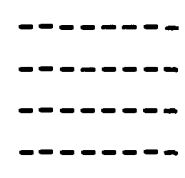 & 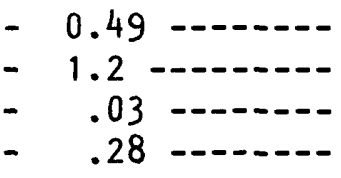 & $\begin{array}{l}27.0 \\
26.0 \\
27.0 \\
26.5\end{array}$ & $\begin{array}{r}29.0 \\
29.5\end{array}$ \\
\hline
\end{tabular}




\section{REFERENCES}

Austin, Smith and Associates, Inc., 1967, Engineering report covering a master planned water supply and distribution system as well as a sewerage system for the Central Islands of the Yap District, Western Caroline Islands.

Bridge, Josiah, 1946, Mineral resources of Yap and Fais, Western Caroline Islands in Mineral resources of Micronesia, v. 3-1, section 3: U.S. Commercial Co., Honolulu, Hawai i, Unpublished typewriiten report, p. 36-47.

Friis, H. R., 1967, The Pacific basin. A history of its geographical exploration: American Geographic Society, New York, 457 p.

Government of the Philippine Islands, Weather Bureau, Manila Central Observatory; Monthly and annual summaries, 1911-20.

Great Britain Naval Intelligence Division, 1945, Geographic Handbook Series, Pacific Islands, V. IV, Western Pacific (New Guinea and Islands northward): p. $361-411$.

Hawai i Architects and Engineers, Inc., 1968, Yap, Yap District: Trust Territory Physical Planning Program, Honolulu, Hawaii, 66 p.

Institute of Human Relations, Yale University, 1943, Meteorology of the Caroline Islands: Strategic Bulletins of Oceania, no. 7, p. 8 and 9.

Johnson, C. G., and others, 1960, Military Geology of Yap Islands: Headquarters U.S. Army Pacific, Office of the Engineer, $164 \mathrm{p}$.

Kaiser, Erich, 1902, Alte Gesteine von den Karolinen [01d rock types from the Carolines]: Zeitschr. Deutsche Geol. Gesell. v. 54, p. 62-63.

Lyon Associates, Inc., 1980, Conceptual water development plans for the Colonia, Tomil-Gagil, and southern Yap areas of Yap State: Honolulu, Hawaii, 87 p., App. A-E.

Mitt(h)eilungen von Forschungreisenden und Gelehrten aus den deutschen

Schutzgebieten [Communications from explorers and scientists from the German protectorates]: Annual publications, Berlin, 1901, p. 205-207; 1902, p. 169; 1913, p. 352-353.

Nance, Tom, 1979, Yap Islands, Groundwater exploration, April to August 1979: Lyon Associates, Inc., Honolulu, Hawai i, 78 p. App. 63 p.

---- 1982, Yap Island water well development, January to March 1982: Lyon Associates, Inc., Honolulu, Hawai i, 48 p. 
Naval Medical Asșociation, Investigation of the drinking water in the South Sea Islands: Bulletin, v. 17, no. 1, p. 42-56.

Piper, A. M., 1946-47, Water resources of Guam and the ex-Japanese mandated islands in the western Pacific: Unpublished typewritten report, $181 \mathrm{p}$. Smithsonian Institution, 1934, World weather records, 1921-1930: From Smithsonian Miscellaneous Collections, City of Washington, v. 90, p. 392.

-.-- 1947, World weather records, 1931-1940: From Smithsonian Miscellaneous Collections, Washington, D.C., v. 105, p. 415.

Sunn, Low, Tom and Hara, Inc., 1971, Feasibility studies for the installation of communal water facilities in the populated areas of Tomil, Gagil, and Kanifay: Honolulu, Hawaii, 24 p.

Tayama, Risaboro, 1935, Geomorphology, geology, and coral reefs of the Yap Islands, Institute of Geology and Paleontology, Faculty of Science, Tohoku Imp. University, Contribution no. 19, p. 1-43 (Japanese).

Trust Territory of the Pacific Islands, 1979, Quarterly Bulletin of Statistics, v. 2 .

U.S. Department of State, Report on the administration of the Trust Territory of the Pacific Islands, transmitted by the United States of America to the United Nations: Annual reports, 1953-73.

U.S. Geological Survey, 1971-74, Water resources data for Hawai i and other Pacific areas, (Part 1. Surface water records, Part 2. Water quality records: Reports issued annually.) water years 1971-74: U.S. Geological Survey Water-Data Reports HI-71-1, 333 p.; HI-72-1, 280 p.; HI-73-1, 264 p.; HI-74-1, 277 p.

1975-76, Water resources data for Hawai $i$ and other Pacific areas, water years 1975 and 1976: U.S. Geological Survey Water-Data Reports HI-75-1

$401 \mathrm{p} .$, and $\mathrm{HI}-76-1445 \mathrm{p}$.

--- 1977, Surface water supply of the United States, 1966-70. Part 16, Hawaii and other Pacific areas: U.S. Geological Survey Water Supply Paper 2137, p. 668-679.

1977-80, Water resources data for Hawai and other Pacific areas, water years 1977-80, v. 2. Trust Territory of the Pacific Islands, Guam, American Samoa, and Northern Mariana Islands: U.S. Geological Survey Water-Data Reports HI-77-2, 90 p.; HI-78-2, 108 p.; HI-79-2, 126 p.; HI-80-2, 158 p. 
U.S. Geological Survey, 1981, Water resources data, Hawaii-other Pacific areas, Water year 1981, v. 2. Guam, Northern Mariana Islands, Federated States of Micronesia, Palau Islands, and American Samoa: U.S. Geological Survey Water-Data Report HI-81-2, $148 \mathrm{p}$.

U.S. National Oceanic and Atmospheric Administration, 1956-72, Climatological Data, Pacific: vols. 1-17, nos. 1-12.

-.-- 1973-83, Climatological data, Hawai and Pacific: vols. 69-78, nos. 1-12; v. 79, nos. 1-5.

-..- 1981, Local climatological data, annual summary with comparative data, 1981--Yap Island, Pacific: 4 p.

U.S. Navy Department, Hydrographic office, 1938, Sailing directions for the Pacific Islands, v. 1, H. 0. no. 165, Western Groups, p. 577.

U.S. Weather Bureau, 1959, World weather records, 1941-50: Washington, D. C., p. 1165.

World Health Organization, 1971, International Standards for drinking water, 3rd ed., $70 \mathrm{p}$.

Young, M. W. H., Wong, D. E., Chun, M. J., and Young, R. H. F., 1977, Sanitary survey of major municipal water systems, Trust Territory of the Pacific Islands: Unpublished processed report, $95 \mathrm{p}$. 